VILNIAUS GEDIMINO TECHNIKOS UNIVERSITETAS

Giedrè RAKAUSKIENĖ

\title{
ŠALIES KONKURENCINGUMO SKATINIMO SPRENDIMŲ PAGRĮSTUMO DIDINIMAS
}

\section{DAKTARO DISERTACIJA}

SOCIALINIAI MOKSLAI, EKONOMIKA (04S)

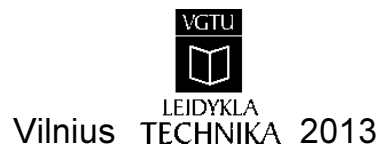


Disertacija rengta 2008-2013 metais Vilniaus Gedimino technikos universitete.

\section{Mokslinis vadovas}

Doc. dr. Rima TAMOŠIŪNIENĖ (Vilniaus Gedimino technikos universitetas, socialiniai mokslai, ekonomika-04S).

VGTU leidyklos TECHNIKA 2187-M mokslo literatūros knyga http://leidykla.vgtu.lt

ISBN 978-609-457-580-8

(C) VGTU leidykla TECHNIKA, 2013

(C) Giedrè Rakauskienè, 2013

giedre.rakauskiene@vgtu.lt 
VILNIUS GEDIMINAS TECHNICAL UNIVERSITY

Giedrè RAKAUSKIENĖ

THE INCREASE OF VALIDITY OF NATIONAL COMPETITIVENESS' PROMOTION DECISIONS

DOCTORAL DISSERTATION

SOCIAL SCIENCES,

ECONOMICS (04S)

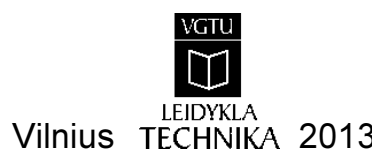


Doctoral dissertation was prepared at Vilnius Gediminas Technical University in 2008-2013.

\section{Scientific Supervisor}

Assoc Prof Dr Rima TAMOŠIŪNIENĖ (Vilnius Gediminas Technical University, Social Sciences, Economics - 04S). 


\section{Reziumè}

Disertacijoje nagrinejjami šalies konkurencingumo skatinimui skirtų sprendimų parengimo ir pagrindimo būdai ir priemonès. Šalies konkurencingumo sprendimų svarbos suvokimas, jų rengimo procese esančios problemos ir poreikis efektyviai panaudoti konkurencingumo skatinimui skiriamus finansinius išteklius atskleidžia priimamų sprendimų pagrịstumo didinimo būtinybę, kuri identifikuoja konkurencingumo klausimams spręsti skirtų priemonių trūkumo problemą. Atsižvelgiant $i$ tai, disertacijoje keliamas tikslas - parengti ir empiriškai patikrinti šalies konkurencingumo vertinimo metodą ir konkurencingumo pokyčio optimizavimo modelį, kurių taikymas leistų pagristi šalies konkurencingumo skatinimo sprendimus.

Disertaciją sudaro ịvadas, trys skyriai ir bendrosios išvados.

Ivade suformuluota mokslinè darbo problema, pagrịstas jos aktualumas, ivardinti tyrimų objektas, darbo tikslas ir uždaviniai, pristatyta tyrimų metodika, atskleistas darbo mokslinis naujumas ir gautų rezultatų praktinè reikšmé, ịvardinti ginamieji teiginiai.

Pirmajame darbo skyriuje atskleistas šalies konkurencingumo klausimo aktualumas ir atlikta ịvairių šaliu patirties analizè, atskleidžianti su konkurencingumu susijusių sprendimu rengimo institucinius ir metodinius aspektus. Taip pat, siekiant patikslinti šalies konkurencingumo apibrèžimą, nustačius svarbią įtaką skirtingu požiūrių atsiradimui turëjusias teorijas ir mokyklas, atlikta dažniausiai naudojamų šalies konkurencingumo sampratos interpretacijų analizè. Apžvelgus teorinius šalies konkurencingumo modelius, atlikta įvairių organizacijų pateikiamų šalies konkurencingumo vertinimui naudojamų veiksnių rinkinių analizè ir, remiantis ja, sudaromas patikslintą šalies konkurencingumo apibrèžimą atitinkantis veiksnių rinkinys. Atliekant mokslinès literatūros analizę atskleidžiamas ir pagrindžiamas kiekvieno rinkinị sudarančio veiksnio turinys.

Antrajame skyriuje, ivvardinus šalies konkurencingumo skatinimo sprendimų pagrịstumo didinimo prielaidas, pasiūlytas šalies konkurencingumo vertinimo metodas ir sudarytas šalies konkurencingumo pokyčio optimizavimo modelis.

Trečiajame skyriuje aprašyti empirinių tyrimu, kuriais patikrintas darbe pateiktų pasiūlymų praktinis priimtinumas, eiga ir rezultatai.

Disertacijos tema paskelbti 7 straipsniai: keturi - mokslo žurnaluose; vienas - konferencijos medžiagoje ISI Proceedings; du - recenzuojamose tarptautinių konferencijų medžiagose. 


\section{Abstract}

Dissertation analyses means and approaches of the national competitiveness promotion decisions' preparation and substantiation. The understanding of importance of national competitiveness' decisions, the problems arising in these decisions preparation process and the need financial resources to promote national competitiveness to use efficiently, impose the necessity to increase validity of these decisions. This necessity identifies the problem - lack of means that are designed specifically for national competitiveness' issues solutions. Accordingly, the aim of dissertation is to develop and test empirically national competitiveness' assessment method and national competitiveness' change optimization model that help to validate national competitiveness' promotion decisions.

The dissertation consists of the introduction, three main chapters and conclusions. The introduction presents the scientific problem, its relevance, the object, aim, tasks and methods of the researches, scientific novelty and practical significance of the dissertation, defended statements.

Chapter 1 reveals topicality of issue of national competitiveness and analyses different countries' practice, which reveals the institutional and methodological aspects of preparation of national competitiveness' promotion decisions. Furthermore, in order to clarify the definition of national competitiveness, according to identified the most important theories and schools that mostly influenced emergence of different viewpoints; the analysis of most commonly used interpretations of the conception of national competitiveness is performed. Theoretical national competitiveness' models are reviewed, comparative analysis of factors' sets used for national competitiveness assessment by different organizations is performed and, according to the results, set of factors which reflects the clarified definition of national competitiveness is developed. On the basis of scientific literature analysis the content of each factor from the set is disclosed and approved.

In the Chapter 2, basing on assumptions how to increase the validity of national competitiveness' decisions, national competitiveness' assessment method is proposed and national competitiveness' change optimization model developed.

Chapter 3 describes process and results of empirical investigations that examine practical acceptability of the proposals.

7 articles focusing on the subject of the dissertation are published: 4 articles in the scientific journals, 1 article - in ISI Proceedings, 2 articles - in material reviewed during international conferences. 


\section{Žymèjimai}

\section{Simboliai}

$\widetilde{R}_{j}$ - normalizuota rodiklio reikšme;;

$\max (R)$ - didžiausia galima rodiklio reikšmé;

$R_{j}$ - tikroji rodiklio reikšmè;

$\min (R)$ - mažiausia galima rodiklio reikšmè;

$V_{j}-j$-asis šalies konkurencingumo veiksnys;

$w_{j i}-j$-ojo veiksnio $i$-ojo dalinio veiksnio santykinis reikšmingumas;

$v_{j i}-j$-ojo veiksnio $i$-asis dalinis veiksnys;

$m_{j}-j$-aji veiksnị sudarančių dalinių veiksnių skaičius;

$K$ - šalies konkurencingumas;

$w_{j}-j$-ojo šalies konkurencingumo veiksnio santykinis reikšmingumas;

$n$ - veiksnių skaičius;

$r$ - ekspertų skaičius;

$P$ - kvadratinè matrica;

$\lambda_{\max }$ - didžiausia matricos tikrinè reikšmè;

$S_{I}$ - ekspertų vertinimų suderinamumo indeksas;

$S_{S}$ - suderinamumo santykis;

$S_{A}-$ atsitiktinio suderinamumo indeksas;

$W$ - konkordancijos koeficientas;

$S$ - veiksnių rangų sumų nuokrypių nuo bendro vidurkio kvadratų suma;

$\chi^{2}$ - konkordancijos koeficiento reikšmingumo nustatymo koeficientas; 
$T_{j}-j$-ojo eksperto susietų rangų rodiklis;

$H_{j}$ - lygių rangu $j$-ojo eksperto skaičius;

$t_{i}-$ lygių susietų rangų $i$-tasis grupès skaičius;

$s_{j}-$ atsitiktinis dydis, nusakantis $j$-ojo veiksnio pokyti;

$E s_{j}-r$ ekspertų pateiktų veiksnių pokyčių ịverčių rinkinio vidurkis;

$D s_{j}-$ dydžio $s_{j}$ dispersija;

$\sigma s_{j}-$ atsitiktinio dydžio $s_{j}$ standartinis nuokrypis;

$x_{j}$ - finansinių išteklių suma skiriama $j$-ajam veiksniui;

$c$ - šalies konkurencingumo skatinimui skiriama finansinių išteklių suma;

$\Delta K$ - šalies konkurencingumo pokytis;

$u_{\alpha}-$ normaliojo skirstinio kritinè reikšmė lygmens $\alpha$;

$z$ - papildomas kintamasis.

\section{Santrumpos}

AHP - Analitinès hierarchijos procesas;

BVP - Bendrasis vidaus produktas;

$\mathrm{CB}$ - Centrinis bankas;

CSD - Centrinis statistikos departamentas (angl. CSO - Central Statistics Office);

EBPO - Ekonominio bendradarbiavimo ir pletros organizacija (angl. OECD - The Organisation for Economic Co-operation and Development);

ECB - Europos centrinis bankas (angl. ECB - The European Central Bank);

ERPB - Europos rekonstrukcijos ir pletros bankas (angl. EBRD - European Bank for Reconstruction and Development);

ESTI - Ekonominių ir socialinių tyrimų institutas (angl. ESRI - The Economic and Social Research Institute);

JAV - Jungtinès Amerikos valstijos;

JTO - Jungtinių tautų organizacija (angl. UNO - The United Nations Organization);

PB - Pasaulio bankas (angl. WB - The World Bank);

PEF - Pasaulio ekonomikos forumas (angl. WEF - The World Economic Forum);

PPO - Pasaulio prekybos organizacija (angl. WTO - The World Trade Organization);

PPSI - Pramonès politikos studijų institutas (angl. IPS - The Institute for Industrial Policy Studies);

TVF - Tarptautinis valiutos fondas (angl. IMF - International Monetary Fund);

TVPI - Tarptautinis vadybos pletros institutas (angl. IMD - The International Institute for Management Development). 


\section{Turinys}

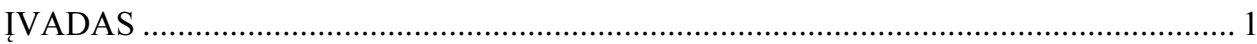

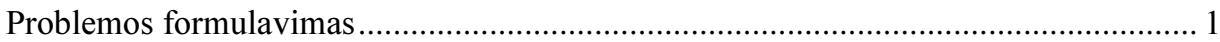

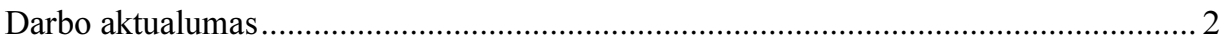

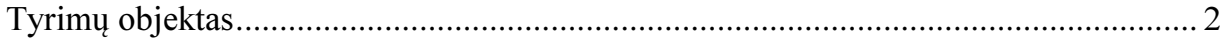

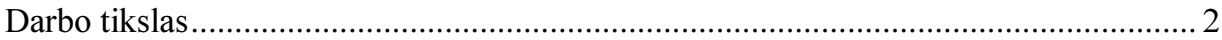

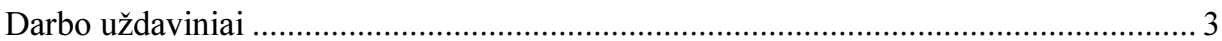

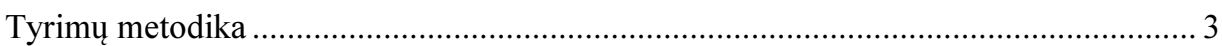

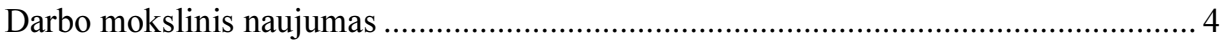

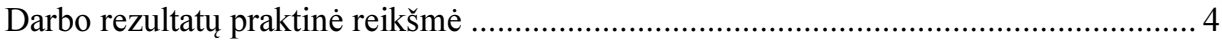

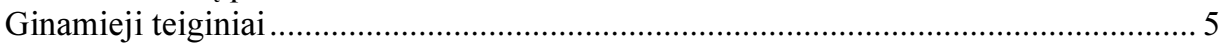

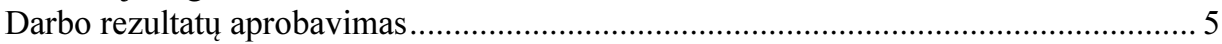

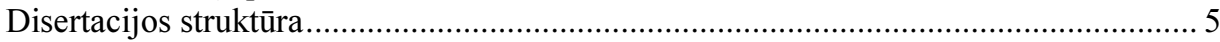

1. ŠALIES KONKURENCINGUMAS: AKTUALUMAS, ŠALIŲ PATIRTIS,

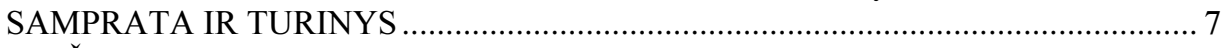

1.1. Šalies konkurencingumo klausimo aktualumas ………………………………....... 8

1.2. Šalies konkurencingumo sprendimų rengimo patirtis instituciniu ir metodiniu

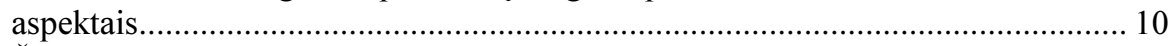

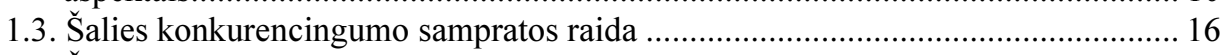

1.4. Šalies konkurencingumo sampratos interpretacijų analizè ..................................... 20

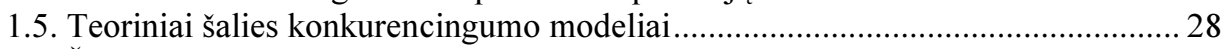

1.6. Šalies konkurencingumą lemiantys veiksniai ................................................... 33 
2. ŠALIES KONKURENCINGUMO VERTINIMAS IR POKYČIO

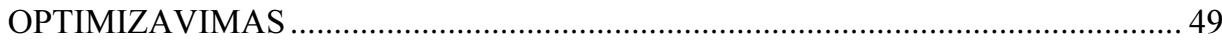

2.1. Šalies konkurencingumo skatinimo sprendimų pagrịstumo didinimo prielaidos ir

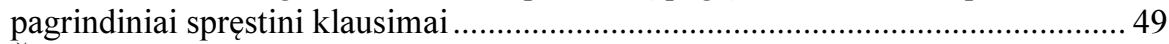

2.2. Šalies konkurencingumo vertinimo metodas .....................................................53

2.3. Šalies konkurencingumą lemiančių veiksnių reikšmingumų nustatymas ...............58

2.4. Šalies konkurencingumą lemiančių veiksnių būklès pokyčių dèl investuotų

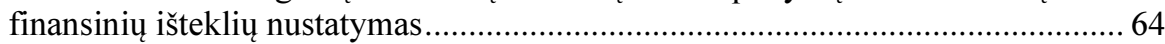

2.5. Šalies konkurencingumo pokyčio optimizavimo modelis ...................................... 66

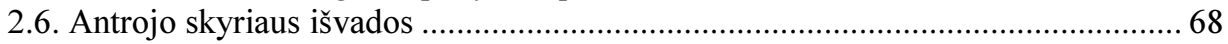

3. LIETUVOS KONKURENCINGUMO VERTINIMO IR POKYČIO

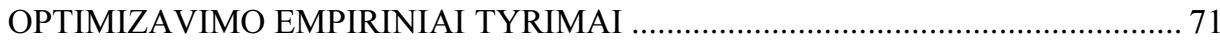

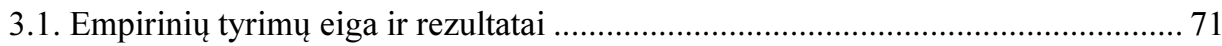

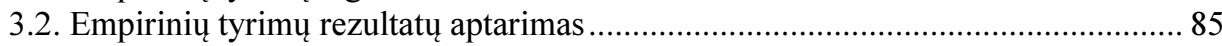

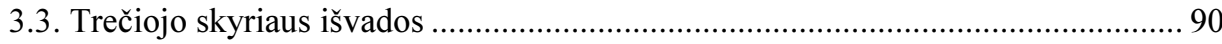

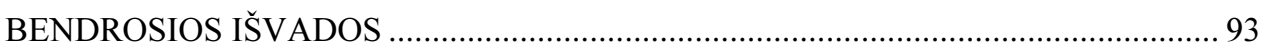

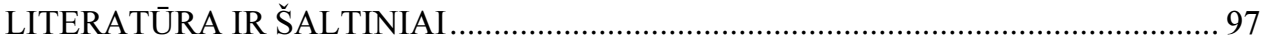

AUTORĖS MOKSLINIŲ PUBLIKACIJŲ DISERTACIJOS TEMA SĄRAŠAS......... 113

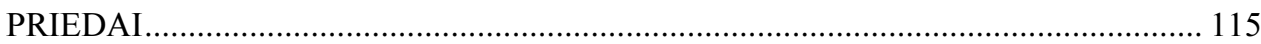

A priedas. Dalinių veiksnių rodikliai ir jų gavimo šaltiniai........................................ 116

B priedas. Lietuvos konkurencingumo dalinių veiksnių rodiklių reikšmès ................ 120

C priedas. Lietuvos konkurencingumo veiksnių reikšmingumų nustatymo pavyzdys 123

D priedas. Lietuvos konkurencingumo pokyčio optimizavimo uždavinio sprendimo rezultatai 


\section{Contents}

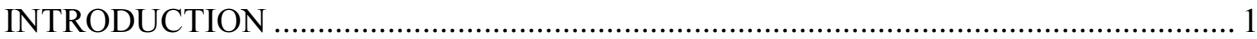

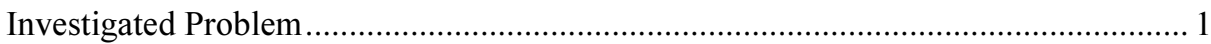

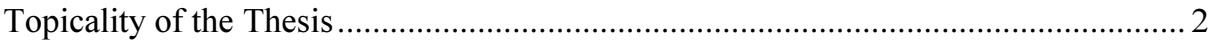

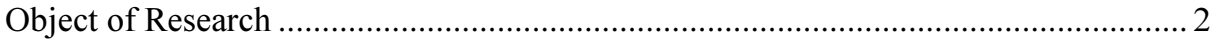

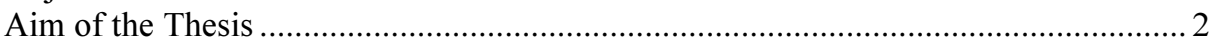

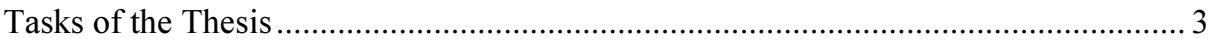

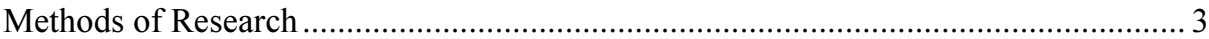

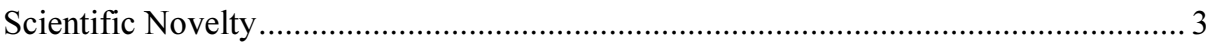

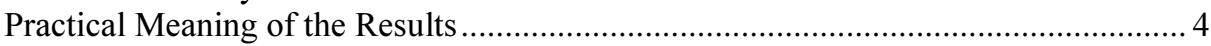

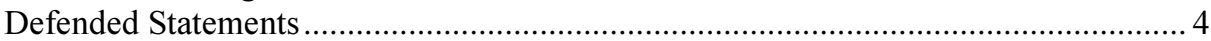

Approval of the Results .................................................................................. 5

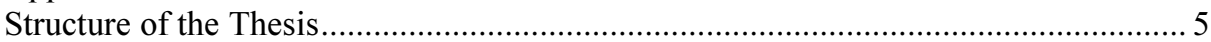

1. NATIONAL COMPETITIVENESS: TOPICALITY, COUNTRIES' PRACTICE,

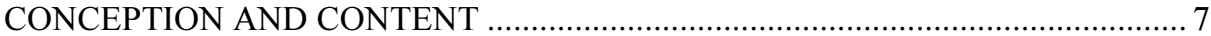

1.1. Topicality of the National Competitiveness Issue ............................................ 8

1.2. Practice of National Competitiveness Decisions' Preparation: Institutional and

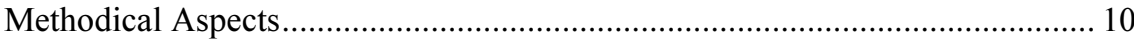

1.3. Evolution of National Competitiveness Conception ......................................... 16

1.4. Analysis of Interpretations of National Competitiveness' Conception ...............22

1.5. Theoretical Models of National Competitiveness ............................................... 28 
1.6. Factors That Influence National Competitiveness................................................. 33

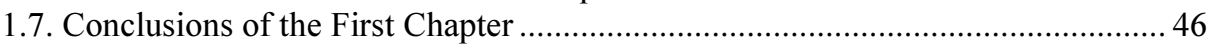

2. NATIONAL COMPETITIVENESS' ASSESSMENT AND

CHANGE OPTIMIZATION

2.1. Assumptions for Increase of Validity of National Competitiveness' Promotion

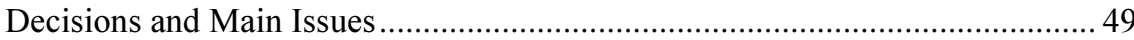

2.2. National Competitiveness' Assessment Method ................................................. 53

2.3. Determination of Significances of National Competitiveness' Factors................ 58

2.4. Determination of Changes of Condition of National Competitiveness' Factors

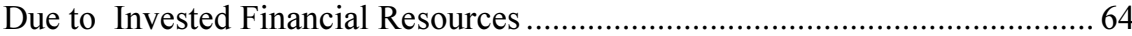

2.5. National Competitiveness' Change Optimization Model ........................................66 66

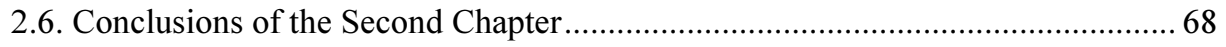

3. EMPIRICAL INVESTIGATIONS ON COMPETITIVENESS' ASSESSMENT AND

CHANGE OPTIMIZATION IN LITHUANIA …….............................................. 71

3.1. Empirical Researches and Their Results ........................................................ 71

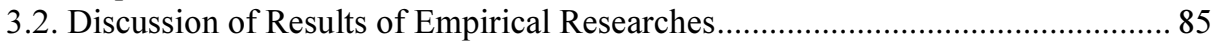

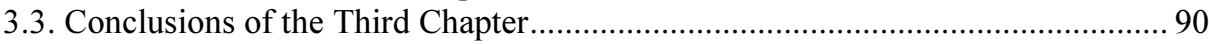

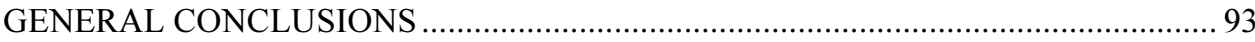

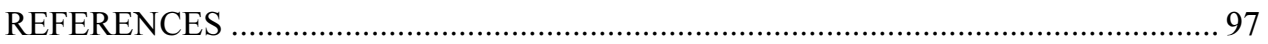

LIST OF THE AUTHOR'S SCIENTIFIC PUBLICATIONS ON THE TOPIC

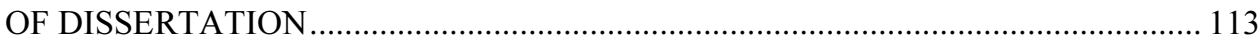

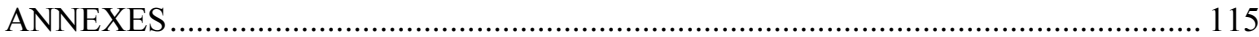

Annex A. Sub-factors' Indicators and Their Sources ............................................... 116

Annex B. Values of Lithuania's Competitiveness Sub-factors' indicators .............. 120

Annex C. Example of Calculation of Lithuania's Competitiveness Factors

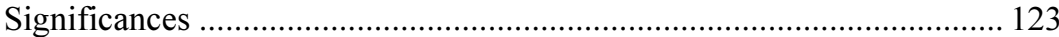

Annex D. Results of Solution of Lithuania's Competitiveness Change Optimization

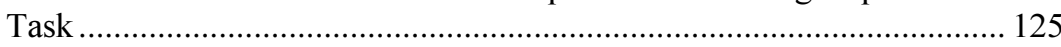




\section{Ivadas}

\section{Problemos formulavimas}

İvairių šalių politikos atstovai ieško sprendimų, kaip padidinti ir išlaikyti aukštą šalies konkurencingumą. Tam tikslui įvairiose šalyse steigiamos svarbų vaidmeni sprendimu prièmimo procese atliekančios institucijos, diskutuojama tarp skirtingus interesus atstovaujančių subjektų, vertinamas šalies konkurencingumas ir, atsižvelgiant i gautus rezultatus, kuriamos strategijos. Siekiant igyvendinti šalių strategijose užsibrèžtus tikslus, kuriamos įvairios priemonès, kurioms ịgyvendinti, atsižvelgiant $i$ jų sudètingumą ir finansinį imlumą, skiriami finansiniai ištekliai. Kaip ir bet kuriai kitai sričiai, šalies konkurencingumui skatinti skiriami finansiniai ištekliai yra riboti, todèl natūralu, kad kyla poreikis juos panaudoti efektyviai tikintis didžiausio galimo šalies konkurencingumo augimo. Čia išryškejja efektyvių šalies konkurencingumo skatinimo sprendimų būtinybè, kuri atskleidžia pagrindinę problemą - pasigendama priemonių, konkrečiai skirtų šalies konkurencingumo klausimams spręsti. Galimybès sukurti tokias priemones didžiaja dalimi prarandamos dèl dviejų tarpusavyje glaudžiai susijusių problemų. Pirma, nors mokslinejje literatūroje šalies konkurencingumo klausimu diskutuojama jau nuo XVI amžiaus, tačiau šiandien vis dar nèra aiškus šalies konkurencingumo apibrěžimas. Antra, mokslininkams nesutariant ir neprieinant vieningos 
nuomonès dèl šalies konkurencingumo sampratos, prarandama galimybè nustatyti šalies konkurencingumo turinį atskleidžiančius veiksnius.

\section{Darbo aktualumas}

Globalizacijos, ekonominès integracijos ir sparčios naujų informaciniu technologijų plètros sąlygomis gyvenančioms šalis itin aktualus yra jų konkurencingumo klausimas. Sprendžiant ši klausimą, šalyse daug dėmesio skiriama esamos konkurencingumo būklès vertinimui, kurio atlikimą ne vienos šalies vyriausybè patikejjo iš dalies tam tikslui ịkurtoms nacionalinio konkurencingumo taryboms. Konkurencingumo vertinimo metu gautu rezultatu pagrindu formuojamos rekomendacijos, kurios teikiamos už sprendimų priemimą atsakingiems subjektams. Suvokiant tokių rekomendacijų svarbą nacionalinio lygio sprendimų prièmimo procese, ypač aktualus tampa jų pagrisstumo klausimas.

Šalies konkurencingumo skatinimui reikalingų sprendimu prièmimui skirtų rekomendacijų pagrįstumo didinimo aktualumą pagrindžia ir šalių patirtis, kuri atskleidžia, kad šalies konkurencingumo vertinimui naudojamos skirtingos, kai kuriais atvejais silpnai teoriškai pagrịstos vertinimo metodikos. Netiksliu vertinimų pagrindu formuluojamos rekomendacijos ir jų apsiribojimas ižvalgomis, patarimais, rečiau, konkrečiais sprendimais, menkina sprendimų pagrịstumą ir klaidina už sprendimu prièmimą atsakingus subjektus. Toks sprendimų prièmimo pagrindas nesuteikia galimybès priimti efektyvius šalies konkurencingumo skatinimo sprendimus ir pasiekti šalies konkurencingumo augimą.

Palyginti menka šalių patirtis rengiant konkurencingumo skatinimo sprendimus, dalinai dèl to atsiradusios anksčiau aptartos problemos, jų sprendimui reikiamų priemonių nebuvimas ir mokslinių tyrimų šioje srityje trūkumas rodo šio darbo svarbą ir aktualumą.

\section{Tyrimų objektas}

Darbo mokslinių tyrimų objektas - šalies konkurencingumo skatinimui skirtų sprendimų parengimo ir pagrindimo būdai ir priemonès.

\section{Darbo tikslas}

Šio darbo pagrindinis tikslas - parengti ir empiriškai patikrinti šalies konkurencingumo vertinimo metodą ir konkurencingumo pokyčio optimizavimo modeli, kurių taikymas leistų pagrįsti šalies konkurencingumo skatinimo sprendimus. 


\section{Darbo uždaviniai}

Siekiant darbo tikslo formuluojami tokie uždaviniai:

1. Išanalizuoti ịvairių šalių patirtị rengiant konkurencingumo skatinimo sprendimus ir atskleisti sprendimų rengimo problemas.

2. Atskleisti šalies konkurencingumo sampratos kitimą laiko perspektyvoje ir, atlikus mokslinèje bei praktinèje literatūroje pateikiamų sampratos interpretacijų analizę, patikslinti šalies konkurencingumo apibrèžimą.

3. Nustatyti šalies konkurencingumą lemiančius veiksnius ir, remiantis mokslinès literatūros analize, išryškinant svarbiausius aspektus, atskleisti kiekvieno veiksnio turinį.

4. Pasiūlyti šalies konkurencingumo vertinimo metodą, leidžiantị galimai tiksliau nustatyti esamą šalies konkurencingumo būklę.

5. Parengti šalies konkurencingumo pokyčio optimizavimo modelį, sudarantị prielaidas pagrịsti šalies konkurencingumo skatinimo sprendimus.

6. Patikrinti šalies konkurencingumo vertinimo metodo ir šalies konkurencingumo pokyčio optimizavimo modelio praktini priimtinumą atliekant empirini tyrimą Lietuvos atveju.

\section{Tyrimų metodika}

Darbe taikyta analitinio tyrimo metodologija, leido atskleisti šalies konkurencingumo klausimo aktualumą, šaliu patirties aspektus ir problematiką, patikslinti šalies konkurencingumo apibrèžimą ir nustatyti konkurencingumą lemiančius veiksniu. Taikyti lyginamosios analizès, logikos, sintezès ir apibendrinimo metodai leido pasiūlyti šalies konkurencingumo vertinimo metodą. Šalies konkurencingumo pokyčio optimizavimo modelio sudarymas grindžiamas tikimybių teorija ir matematiniu modeliavimu.

Atliekant empirinius tyrimus taikyti stochastinio programavimo, statistiniu duomenu apdorojimo, analitinès hierarchijos proceso, ekspertinio vertinimo ir empirinių duomenų analizès metodai. 


\section{Darbo mokslinis naujumas}

Rengiant disertaciją buvo gauti šie ekonomikos mokslui nauji rezultatai:

1. Atskleista ivvairių šalių patirtis rengiant konkurencingumo skatinimo sprendimus, išskirtinį demesị skiriant trumpą veiklos istoriją turinčioms ir dèl to mokslininkų beveik netyrinètoms nacionalinio konkurencingumo taryboms. Mokslinę literatūrą praturtinančios žinios apie minètų tarybų veiklą sudaro prielaidas tolimesniems tyrinejjimams.

2. Susistemintos žinios apie dažniausiai šiandien pateikiamas šalies konkurencingumo sampratos interpretacijas nulemusias teorijas ir mokyklas papildo mokslini šio reiškinio pažinimą. Nuodugnus šios sampratos pažinimas leido patikslinti šalies konkurencingumo apibrěžimą.

3. Šalies konkurencingumo reiškinio pažinimą taip pat praplečia šalies konkurencingumui vertinti naudojamų veiksnių rinkinių analizès pagrindu sudarytas bei mokslinès literatūros analize pagrịstas šalies konkurencingumo turinį atskleidžiantis veiksnių rinkinys.

4. Mokslinis potencialas šalies konkurencingumo tema papildytas dvejomis naujomis šalies konkurencingumo klausimams spręsti skirtomis priemonėmis - šalies konkurencingumo vertinimo metodu ir šalies konkurencingumo pokyčio optimizavimo modeliu.

\section{Darbo rezultatų praktinè reikšmè}

Parengtas šalies konkurencingumo vertinimo metodas yra tvirtas pagrindas vertinimo metodikos sukūrimui, kuri už sprendimų rengimą atsakingose institucijose gali būti naudojama nustatant šalies konkurencingumo būklę ir priimtų sprendimų efektyvumą.

Sudaryto šalies konkurencingumo pokyčio optimizavimo modelio, kaip sprendimu paramos priemonès naudojimas suteiks galimybę institucijoms pateikti labiau pagrịstas rekomendacijas, o už sprendimų prièmimą atsakingiems subjektams priimti efektyvesnius šalies konkurencingumo skatinimo sprendimus. Priimti efektyvūs sprendimai prisidètu prie strategijos efektyvumo didèjimo ir galiausiai - šalies konkurencingumo augimo.

Darbe pateiktų sprendimų pagrindu gali būti sukurta šalies konkurencingumo sprendimu paramos sistema. 


\section{Ginamieji teiginiai}

1. Pagristo, vienareikšmio šalies konkurencingumo sampratos apibrèžimo prièmimas ir, remiantis juo, konkurencingumo veiksnių rinkinio sudarymas yra pagrindiniai vertinimo tikslumą didinantys būdai.

2. Šalies konkurencingumo vertinimo tikslumą taip pat didina šalies konkurencingumą lemiančių veiksnių svarbos bendram konkurencingumui ìvertinimas. Todèl turi būti nustatomi veiksnių reikšmingumai.

3. Su šalies konkurencingumu susijusių sprendimų prièmimo pagrindas, kuri sudaro konkurencingumo vertinimas, yra nepakankamas. Siekiant priimti pagrịstus ir efektyvius sprendimus turi būti pasitelkiamos papildomos priemonès.

4. Šalies konkurencingumo skatinimui skirtų finansinių išteklių efektyvaus paskirstymo planas, gautinas išsprendus šalies konkurencingumo pokyčio optimizavimo uždavini sudaro prielaidas už sprendimų prièmimą atsakingiems subjektams priimti efektyvesnius sprendimus.

\section{Darbo rezultatų aprobavimas}

Disertacijos tema yra išspausdinti 7 moksliniai straipsniai: keturi - recenzuojamuose mokslo žurnaluose ir trys - recenzuojamose tarptautinių konferencijų medžiagose. Rengiant disertaciją atliktų tyrimų rezultatai buvo paskelbti trijose tarptautinèse konferencijose:

- 2-oje tarptautinëje mokslinëje konferencijoje "Knowledge Society“ 2009 m. Nesebare, Bulgarijoje;

- 6-oje tarptautinejje konferencijoje „Business and Management 2010“ 2010 m. Vilniuje, Lietuvoje;

- 3-ioje tarptautinèje mokslinejje konferencijoje "Knowledge Society“ $2010 \mathrm{~m}$. Sozopolyje, Bulgarijoje.

\section{Disertacijos struktūra}

Disertaciją sudaro įvadas, trys skyriai, išvados, literatūros sąrašas ir keturi priedai. Disertacijos apimtis - 114 puslapių, be priedų. Darbe yra 36 numeruotos formulès, 16 paveikslų ir 28 lentelès. Rašant disertaciją panaudoti 222 šaltiniai. 



\section{Šalies konkurencingumas: aktualumas, šalių patirtis, samprata ir turinys}

Šalies konkurencingumas - sąvoka tarp mokslininkų kelianti daug prieštaravimų. Siekiant aiškumo, skyriuje atskleidžiamas šalies konkurencingumo klausimo aktualumas, atliekama ivvairių šalių patirties rengiant šalies konkurencingumo sprendimus analizè, atskleidžianti esminius institucinius ir metodinius aspektus ir leidžianti ịvardinti problemas bei numatyti jų sprendimo galimybes. Taip pat, siekiant patikslinti šalies konkurencingumo apibrèžimą, nustačius svarbią ịtaką skirtingų požiūrių atsiradimui turèjusias teorijas ir mokyklas, atliekama šalies konkurencingumo sampratos interpretacijų analizè. Apžvelgus teorinius šalies konkurencingumo modelius, atliekama šalies konkurencingumo vertinimui naudojamų veiksnių rinkinių lyginamoji analizè ir jos pagrindu sudaromas patikslintą šalies konkurencingumo apibrèžimą atitinkantis veiksnių rinkinys. Atliekant mokslinès literatūros analizę atskleidžiamas ir pagrindžiamas kiekvieno rinkinị sudarančio veiksnio turinys ir svarba konkurencingumui. Remiantis šiame skyriuje atlikta analize parengti ir moksliniuose žurnaluose išspausdinti trys straipsniai (Staskevičiūtè, Tamošiūnienè 2010; Tamošiūnienè, Staskevičiūtė 2011; Rakauskienè, Tamošiūnienè 2013). 


\section{1. Šalies konkurencingumo klausimo aktualumas}

Praeito amžiaus pabaigoje susidomejjimas šalies konkurencingumu igavo neįikètiną pagreiti ir pastaruoju metu tapo vienu aktualiausių klausimų formuojant bet kurios šalies ekonominę politiką. Neabejojant galima teigti, kad priežastys, lėmusios išaugusị susidomèjimą konkurencingumu makro (šalies, regiono) lygmenyje, yra globalizacija, ekonominė šalių integracija bei sparti naujų informacinių technologijų plètra. Šių iššūkių veikiamoms ir iš užsitęsusios ekonominès recesijos besivaduojančioms šalims, kaip niekada anksčiau, svarbūs tapo jų ekonomikų išlikimo ir konkurencingumo stiprinimo klausimai. Daugelyje šalių, pvz. Jungtinèse Amerikos valstijose, Jungtinèje Karalystejje, Airijoje ir kt., nacionalinio konkurencingumo vertinimas ir jo skatinimo politikos formavimas tapo oficialiomis įvairių valdžios institucijų užduotims.

Žvelgiant i praeitị randama, kad konkurencingumo klausimai pirmiausia pradèti svarstyti Europoje. Praejus pirmajam Europos ekonominès bendrijos funkcionavimo dešimtmečiui buvo susirūpinta, kad Europos ekonominès bendrijos šalys nepajègia modernizuoti savo ekonomikos ir pasivyti Jungtinių Amerikos valstijų. Jau tada aktyvi pramonès politika buvo grindžiama siekiu pasivyti ir pranokti Ameriką (Vilpišauskas 2004). Tuo tarpu Jungtinių Amerikos valstijų susidomèjimo savo konkurencingumu pradžia laikytina $1970 \mathrm{~m}$. pabaiga -1980 m. pradžia, kai rinkas užplūdo produkcija iš Japonijos, kurios ekonomika tuomet pasiekẻ augimo tempą, prilygstantị dabartinei Kinijos ekonomikos plètrai. Tokio staigaus augimo priežastis buvo itin sėkmingas Japonijos eksportas. Tuomet netgi imta tikèti, kad Japonija gali tapti pirmąja pasaulio ekonomika - kad jos augimas iš Jungtinių Amerikos valstijų atims dominuojančiosios ekonomikos poziciją ne tik pasaulio bet ir jos pačios rinkoje.

Būtent Japonijos demonstruojami pranašumai paskatino rengti konkurencingumo studijas tiek Amerikoje tiek pačioje Japonijoje. Amerika šiomis studijomis siekė išskirti ir didinti savo pranašumus, o Japonijai jos buvo reikalingos ekonominès galios, užtikrinsiančios konkurencini pranašumą pačiose svarbiausiose srityse, galimybių paieškai (Thurow 1992; Tyson 1992; Arrison et al. 1992; Bienkowski 2009). Sustiprindamos nacionalinio konkurencingumo svarbą Jungtinès Amerikos valstijos $1988 \mathrm{~m}$. ịsteigè vyriausybinę Konkurencingumo politikos tarybą, kuri buvo atsakinga už ataskaitu apie Amerikos ekonomikos konkurencingumą rengimą ir pasiūlymų dèl efektyvesnès politikos konkurencingumui skatinti teikimą prezidentui ir kongresui. Kiek anksčiau, 1986 m. buvo ịkurta Konkurencingumo taryba savo veiklą tebevykdanti iki šiol. Po daugiau negu dviejų dešimtmečių pagrindinès tarybos funkcijos yra suburti privataus ir viešojo sektorių svarbiausius vadovus atkreipti demesi i Amerikos ilgalaikio konkurencingumo iššūkius; generuoti novatoriškus viešosios politikos sprendimus, idejjas 
paversti veiksmais; vertinti Jungtinių valstijų veiklą globalioje rinkoje, nustatant svarbiausias kliūtis ir galimybes.

$\mathrm{XX}$ a. paskutiniame dešimtmetyje Europos Sajungos konkurencingumas vèl kèlè nuolatines diskusijas, kurias suintensyvino 1993 m. Europos Komisijos išleista Baltoji knyga, skirta augimui, konkurencingumui ir užimtumui (Commission of the European Communities 1993). O jau 1995 m. buvo suburta Konkurencingumo patareju grupè, reguliariai rengusi ataskaitas su siūlymais dèl Europos Sajungos konkurencingumo gerinimo priemonių, kurių dalis vèliau numatytos ir Lisabonos strategijoje (Jacquemin ir Pench 1997). 2000 m. Lisabonoje vykusiame Europos Sajungos viršūnių susitikime iškeltas tikslas siekti, kad Europos Sajungos ekonomika per dešimtmetị taptų ,konkurencingiausia ir dinamiškiausia žinių pagrindu kylančia ekonomika pasaulyje, kuri būtų tvarios ekonomikos plètros, didesnio ir geresnès kokybès užimtumo ir tvirtesnès socialinès sanglaudos derinys“" (Lisbon European Council 2000).

Lietuvoje, kaip ir kitose narystei Europos Sajungoje besirengiančiose šalyse, konkurencingumo tema pradèta domètis 1993 m., kai i paskelbtų Kopenhagos kriteriju sąrašą ịtrauktas Europos Sajungos nare ketinančios tapti šalies „gebejjimas atlaikyti vidaus rinkos konkurencinį spaudimą" (Commission of the European Communities 1997). Po įstojimo į Europos Sajungą Lietuva, aktyviai dalyvaudama siekiant svarbiausio Europos Sąungos tikslo Valstybès ilgalaikeje raidos strategijoje bei Nacionalineje Lisabonos strategijos igyvendinimo programoje, numate konkurencingumo stiprinimo priemones.

Šalies konkurencingumo klausimui tapus itin aktualiu viešojoje erdvejje, pasaulyje padaugejjo mokslinių darbų šia tema. Darbai pagal tematiką gali būti skiriami ị tokias tris grupes:

- darbai, kuriuose siekiama atskleisti ir pagristi šalies konkurencingumo sampratą ir turini (Fagerberg 1988; Koskivaara 1989; Klemetti 1989; Landau 1992; Best 1993; Dollar ir Wolff 1993; Straubhaar 1994; Kitzmantel 1995; Reinert 1995; Trabold 1995; McFetridge 1995; Gough 1996; Fagerberg 1996; Krugman 1996; Orlowski 1997; Oughton ir Whittam 1997; Garelli 1997; Porter 1998; Figueroa 1998; Humphrey 1999; Reiljan et al. 2000; Coldwell 2000; Taner et al. 2000; Cho ir Moon 2002; Budd ir Hirmis 2004; Dunford 2005; Garelli 2006; Aiginger 2006; Nurbel 2007; Kovačič 2007; Berger 2008; Bienkowski 2009);

- darbai skirti sukurti ir įvertinti šalies konkurencingumo vertinimui skirtą metodiką (Rugman 1991; Dunning 1993; Grein ir Craig 1996; Brouthers ir Brouthers 1997; Moon et al. 1998; Porter 1998; Lall 2001; Booysen 2002; Freudenberg 2003; Jacobs et al. 2004; Cho ir Moon 2005; Jin ir Moon 2006; Ketels ir Christian 2006; Bandura 2008; Viassone 2008; Berger ir Bristow 2009); 
- darbai, kuriuose siūlomi šalies konkurencingumo augimą skatinantys sprendimai (Thomas 1996; Shurchuluu 2002; Rondinelli 2003; Bosma et al. 2006).

S̆alies konkurencingumo klausimui nemažai dèmesio skiria ir Lietuvos mokslininkai (Snieška ir Šliburytè 2000; Kvainauskaitè ir Snieška 2002; Snieška et al. 2002; Ginevičius 2004; Vipišauskas 2004; Snieška ir Draksaite 2007; Rutkauskas 2008; Snieška 2008; Ginevičius ir Podvezko 2009; Snieška ir Bruneckienè 2009; Valodkienè ir Snieška 2012).

Nuolatinị politikų domėjimąsi šalies konkurencingumu šiandien skatina šalių konkurencingumo vertinimai, kuriuos atlieka tokios organizacijos kaip Pasaulio bankas, Pasaulio ekonomikos forumas, Ekonominio bendradarbiavimo ir pletros organizacija, Tarptautinis vadybos plètros institutas, Pramonès politikos studiju institutas ir kitos tarptautinès organizacijos bei privačios kompanijos, kuriu pateikiamais rezultatais ịvairių šalių politikos atstovai neretai naudojasi priimdami su konkurencingumo skatinimu susijusius sprendimus.

Itin išaugęs ir toliau vis svarbesniu šalims tampantis konkurencingumo klausimas kelia poreikị plačiau ịvertinti šalių patirtį su konkurencingumu susijusių sprendimų rengimo srityje ir atlikti mokslinès literatūros šiuo klausimu analizę.

\section{2. Šalies konkurencingumo sprendimų rengimo patirtis instituciniu ir metodiniu aspektais}

Šalies konkurencingumo sprendimų prièmimas - sudètingas, ne vieną etapą apimantis, daug dalyvių įtraukiantis ir didelès atsakomybès reikalaujantis procesas, nuo kurio eigos ir rezultatų tiesiogiai priklauso šalies konkurencingumas. Ivairių šalių vyriausybès, ivvertindamos šio proceso sudètingumą, viešojo, privataus ir akademinio sektoriu bendradarbiavimo svarbą ir efektyvių sprendimų priemimo būtinumą steigia nacionalinio konkurencingumo tarybas, kurioms patiki atlikti tam tikras, šalies konkurencingumo skatinimo sprendimų prièmimo procese svarbias funkcijas.

Pirmoji Europoje Nacionalinio konkurencingumo tarybą 1997 metais, siekdama, modernizacijos ir lankstaus prisitaikymo prie kintančių aplinkos sąlygu dèka, užtikrinti nuolatinį ekonomikos augimą ir mažinant ilgalaikị nedarbą padidinti įsitraukimą ir lygybę, ịkūrė Airijos vyriausybè. Pasinaudodamos gera Airijos patirtimi ir pripažindamos nacionalinio konkurencingumo svarbą tokias tarybas vèliau ịsteigè ir kitos šalys (1.1 lentelè). 
1.1 lentelè. Tarybų vaidmuo sprendimų prièmimo procese

Table 1.1. The role of the councils in desicion-making process

\begin{tabular}{|c|c|c|c|c|c|c|c|}
\hline \multirow[b]{2}{*}{$\stackrel{\mathscr{a}}{\bar{E}}$} & \multirow[b]{2}{*}{$\begin{array}{c}\text { Nacionalinis } \\
\text { tikslas } \\
\text { (konkurencingumo } \\
\text { atžvilgiu) }\end{array}$} & \multirow{2}{*}{ Institucija } & \multirow[b]{2}{*}{ 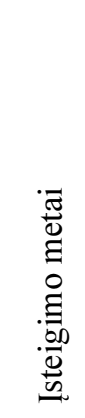 } & \multicolumn{4}{|c|}{$\begin{array}{l}\text { Vaidmuo sprendimų } \\
\text { priemimo procese }\end{array}$} \\
\hline & & & & 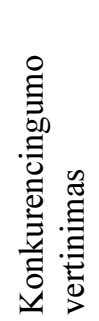 & 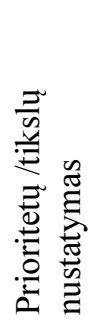 & 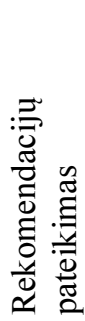 & 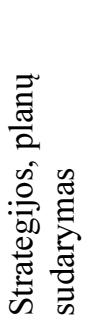 \\
\hline : & $\begin{array}{l}\text { Tvari plètra, } \\
\text { gyvenimo kokybès } \\
\text { gerinimas }\end{array}$ & $\begin{array}{l}\text { Nacionalinio } \\
\text { konkurencin- } \\
\text { gumo taryba }\end{array}$ & 1997 & Taip & Taip & Taip & $\mathrm{Ne}$ \\
\hline :僾 & $\begin{array}{l}\text { Tvarus augimas, } \\
\text { gyvenimo kokybès } \\
\text { gerinimas }\end{array}$ & $\begin{array}{l}\text { Armènijos } \\
\text { nacionalinio } \\
\text { konkurencin- } \\
\text { gumo taryba }\end{array}$ & 2007 & Taip & $\mathrm{Ne}$ & Taip & $\mathrm{Ne}$ \\
\hline : & $\begin{array}{l}\text { Sėkmingas verslas, } \\
\text { aukšti gyvenimo } \\
\text { standartai }\end{array}$ & $\begin{array}{l}\text { Čekijos } \\
\text { konkurencin- } \\
\text { gumo taryba }\end{array}$ & - & Taip & Taip & Taip & $\mathrm{Ne}$ \\
\hline . & $\begin{array}{l}\text { Našumo, gyvenimo } \\
\text { kokybès didinimas }\end{array}$ & $\begin{array}{l}\text { Egipto naciona- } \\
\text { linio konkuren- } \\
\text { cingumo taryba }\end{array}$ & 2004 & Taip & Taip & Taip & $\mathrm{Ne}$ \\
\hline : & $\begin{array}{l}\text { Konkurencinga } \\
\text { ekonomika, aukšti } \\
\text { ir subalansuoti gy- } \\
\text { venimo standartai }\end{array}$ & $\begin{array}{l}\text { Jordanijos nacio- } \\
\text { nalinio konku- } \\
\text { rencingumo } \\
\text { komanda }\end{array}$ & 1997 & Taip & Taip & Taip & $\mathrm{Ne}$ \\
\hline 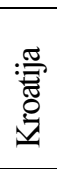 & $\begin{array}{l}\text { Konkurencingumo, } \\
\text { našumo ir } \\
\text { gyvenimo kokybės } \\
\text { didinimas }\end{array}$ & $\begin{array}{l}\text { Nacionalinio } \\
\text { konkurencin- } \\
\text { gumo taryba }\end{array}$ & 2002 & Taip & Taip & Taip & Taip \\
\hline
\end{tabular}

Saltinis: sudaryta autorès

Nacionalinio konkurencingumo tarybos, kurių steigimą inicijavo šalių vyriausybės (išskyrus Egipto nacionalinio konkurencingumo tarybą, kurią ịkūrè grupe iškilių Egipto verslo lyderių ir akademikų) veikia viešosios ir privačiosios partnerystés pagrindu ir vienija tokius skirtingų interesų grupių atstovus kaip vyriausybès deleguoti nariai, verslo atstovais, akademinè bendruomenè. Vienas svarbiausių tarybų tikslų - efektyvaus dialogo tarp skirtingų visuomenès grupių pagalba prisidèti prie šalies konkurencingumo skatinimo. Šio tikslo tarybos siekia 
atlikdamos svarbų vaidmenį pradiniame konkurencingumo sprendimų prièmimo proceso etape - sprendimų rengime.

Bazinè šiandien ivvairiose šalyse veikiančių tarybų funkcija konkurencingumo vertinimas, kurio rezultatų pagrindu toliau yra nustatomi prioritetai, keliami tikslai ir suinteresuotoms šalims (Ministrui Pirmininkui Airijos atveju, pagrindinių partijų lyderiams - Čekijoje ir pan.) pateikiamos rekomendacijos, padedančios priimti strateginius sprendimus, svarbius šalies konkurencingumui. Atsižvelgiant ị pateiktas rekomendacijas suformuluotų sprendimų pagrindu toliau yra kuriamos strategijos, nacionalinès programos.

Strategijos, nacionalinès programos šalyse paprastai rengiamos už strategini planavimą atsakingose institucijose, o nacionalinio konkurencingumo tarybos atlieka tik konsultanto vaidmenį. Išskirtiniai atvejai yra Kroatijos ir Armènijos tarybos, kurių vaidmuo sprendimų prièmimo procese neapsiriboja tik vertinimu ir rekomendacijų pateikimu. 2011 metais Kroatijos Nacionalinio konkurencingumo taryba vyriausybei pateike „Kroatijos plètros iki 2025 chartiją“ - Kroatijos visuomenès viziją, kurios dèka iki $2025 \mathrm{~m}$. turi būti pasiektas vidutinis išsivystymo lygis ir îvykdomi įsipareigojimai Europos Sajungai. Taip pat taryba aktyviai dalyvavo rengiant 2006-2013 m. Kroatijos strateginès plètros programą ir atliko savo pateiktų rekomendacijų igyvendinimo priežiūrą.

Armènijos nacionalinio konkurencingumo taryba siekdama sukurti palankią aplinką šalies našumui augti aktyviai veikia strateginių investicinių projektu plètojime, jiems igyvendinti reikalingos infrastruktūros kūrime ir politikos, reformu inicijavime bei igyvendinime. Siekdama maksimalios naudos vertinime bei projektų ir programų igyvendinime $2008 \mathrm{~m}$. Arménijos vyriausybè dar ịsteigè Armènijos nacionalinio konkurencingumo fondą kuriam patikèjo atsakomybę už konkurencingumo sprendimu igyvendinimą. Siekdamas skatinti sąveiką tarp suinteresuotuju šalių fondas artimai bendradarbiauja su vietos ir tarptautiniu verslu, pagalbos teikejjų bendruomene, ne pelno siekiančiu sektoriumi ir ministerijomis. Veikdamas viešosios-privačiosios partnerystès pagrindu fondas mobilizuoja strategines investicijas, kurios turi potencialą skatinant plètrą ir spartinant konkurencingumo didèjimą.

Atliekant pagrindinę savo funkciją - konkurencingumo vertinimą ịvairiose šalyse veikiančios tarybos naudoja skirtingas vertinimo metodikas (1.2 lentelè). 
1.2 lentelè. Šalies konkurencingumo vertinimo metodiniai principai ịvairiose šalyse

Table 1.2. The methodological principles of national competitiveness' assesment in different countries

\begin{tabular}{|c|c|c|c|c|c|}
\hline \multicolumn{2}{|r|}{$\begin{array}{l}\text { Šalies konkurencingumo } \\
\text { samprata }\end{array}$} & \multirow{2}{*}{$\begin{array}{c}\begin{array}{c}\text { Vertinimo } \\
\text { metodai }\end{array} \\
\text { Lyginamoji analize }\end{array}$} & \multirow{2}{*}{\begin{tabular}{l}
\multicolumn{1}{c}{$\begin{array}{c}\text { Pagrindinès sritys/ } \\
\text { veiksniai }\end{array}$} \\
Verslo sąlygos; našumas; kainos ir \\
išlaidos; darbo jėgos pasiūla; verslo \\
aplinka; fizine aplinka; žinių \\
infrastruktūra
\end{tabular}} & \multirow{2}{*}{\begin{tabular}{l}
\multicolumn{1}{c}{$\begin{array}{c}\text { Duomenu } \\
\text { šaltiniai }\end{array}$} \\
EBPO; Eurostat; \\
JTO; PEF; PPO; \\
CB; CSD; ESTI; \\
Forfas; TVF
\end{tabular}} & \multirow{2}{*}{\begin{tabular}{l}
\multicolumn{1}{c}{ Rezultatų } \\
pateikimas \\
Metinė dviejų dalių \\
konkurencingumo \\
ataskaita; praneši- \\
mai; apžvalgos
\end{tabular}} \\
\hline$: \stackrel{\frac{\pi}{\leftrightarrows}}{:}$ & $\begin{array}{l}\text { Airijos įmonių } \\
\text { gebejjimas konkuruoti } \\
\text { tarptautinese } \\
\text { rinkose }\end{array}$ & & & & \\
\hline 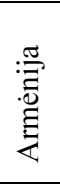 & - & $\begin{array}{l}\text { Lyginamoji analizė; } \\
\text { „deimanto“ modelis; } \\
\text { kitú organizaciju } \\
\text { pateikiamų vertinimų } \\
\text { analize }\end{array}$ & $\begin{array}{l}\text { Verslo sąlygos; našumas; kainos ir } \\
\text { išlaidos; darbo jègos pasiūla; verslo ir } \\
\text { darbo aplinka; fizinè ir technologinè } \\
\text { infrastruktūra; išsilavinimas ir žinios; } \\
\text { mokslas ir inovacijos }\end{array}$ & $\begin{array}{l}\text { PB; PEF; CB; } \\
\text { TVF; ERPB ir kt. }\end{array}$ & $\begin{array}{l}\text { Armėnijos } \\
\text { konkurencingumo } \\
\text { vertinimo ataskaita }\end{array}$ \\
\hline$\frac{\frac{\pi}{7}}{\underbrace{2}}$ & - & $\begin{array}{l}\text { Statistiniai modeliai; } \\
\text { lyginamoji analizė }\end{array}$ & $\begin{array}{l}\text { Bendra ekon. politika; teisinė siste- } \\
\text { ma; viešasis administravimas; fizinė } \\
\text { infrastruktūra; žmogiškieji ištekliai; } \\
\text { fiskalinè/monetarinè politika }\end{array}$ & $\begin{array}{l}\text { Eurostat; Nac. } \\
\text { stat. depart.; PB; } \\
\text { TVF; EBPO; } \\
\text { ECB; apklausa }\end{array}$ & $\begin{array}{l}\text { Čekijos } \\
\text { konkurencingumo } \\
\text { ataskaita }\end{array}$ \\
\hline 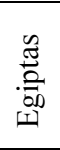 & $\begin{array}{l}\text { Gebejjimas padidinti našu- } \\
\text { mą, kad augtų gyvenimo } \\
\text { standartai ir visi gyventojai } \\
\text { patirtų naudą }\end{array}$ & $\begin{array}{l}\text { Pasaulio } \\
\text { konkurencingumo } \\
\text { ataskaitos analize }\end{array}$ & $\begin{array}{l}\text { Veiksniai, ivardyti Pasaulio konku- } \\
\text { rencingumo ataskaitoje }\end{array}$ & $\begin{array}{l}\text { PEF; PB; Egipto } \\
\text { ekonomikos } \\
\text { studijų centras }\end{array}$ & $\begin{array}{l}\text { Egipto } \\
\text { konkurencingumo } \\
\text { ataskaita }\end{array}$ \\
\hline : & $\begin{array}{l}\text { Nacionalinis } \\
\text { našumas }\end{array}$ & $\begin{array}{l}\text { "deimanto" modelis; } \\
\text { lyginamoji analizė }\end{array}$ & $\begin{array}{l}\text { Banku, draudimo, mėsos perdirbimo, } \\
\text { farmacijos, informacinių ir komuni- } \\
\text { kacijų technologiju, turizmo, gydo- } \\
\text { mojo turizmo ir aukštojo mokslo } \\
\text { sektoriai }\end{array}$ & - & $\begin{array}{l}\text { Jordanijos } \\
\text { nacionalinio } \\
\text { konkurencingumo } \\
\text { ataskaita }\end{array}$ \\
\hline 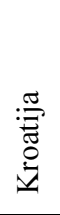 & $\begin{array}{l}\text { Gebejjimas gaminti produk- } \\
\text { ciją, kuri atlaiko vis atvi- } \\
\text { resnių vidaus ir tarptautinių } \\
\text { rinku konkurenciją, ir taip } \\
\text { didinti šalies grynąsias } \\
\text { pajamas }\end{array}$ & $\begin{array}{l}\text { Lyginamoji analizé; } \\
\text { kitų organizacijų } \\
\text { pateikiamų vertinimų } \\
\text { analizé }\end{array}$ & $\begin{array}{l}\text { Eksportas, našumas, išlaidos, investi- } \\
\text { cijos, švietimas, verslo aplinka, } \\
\text { verslo sektorius; infrastruktūros } \\
\text { aplinka }\end{array}$ & - & $\begin{array}{l}\text { Konkurencingumo } \\
\text { ataskaita, leidžiama } \\
\text { kas dvejus metus }\end{array}$ \\
\hline
\end{tabular}

Šaltinis: sudaryta autorès 
Dažniausiai vertinant šalies konkurencingumą yra atliekama lyginamoji analizè, kuri suteikia galimybę pagal konkurencingumą lemiančius veiksnius ịvertinti šalies užimamą padètị kitų šalių ar laiko atžvilgiu. Specialioje literatūroje yra pabrěžiama, kad tinkamam lyginamosios analizès atlikimui svarbiausia yra tiksliai įvardinti lyginamaji objektą, o tada argumentuotai atrinkti ji apibūdinančius veiksnius. Atlikta šalių nacionalinių konkurencingumo tarybų pateikiamų vertinimo metodikų aprašymų analizė atskleidžia, kad ne visos pateikia šalies konkurencingumo apibrèžimą. Todèl neaišku tampa koks yra jų atliekamo vertinimo objektas. Tarp pateikiančiųjų apibrěžimus šalių, samprata šalies konkurencingumo atžvilgiu skiriasi - vienos šalies konkurencingumą sieja su sẻkminga užsienio prekyba ir ji traktuoja kaip šalies gebejjimą gaminti konkurencingą produkciją bei konkuruoti tarptautinèse rinkose (Airija, Kroatija), kitos svarbiausiu laiko gebèjimą didinti šalies našumą (Egiptas, Jordanija).

Atliekant vertinimus šalyse naudojami skirtingi šalies konkurencingumą apibūdinančių veiksnių rinkiniai. Jei yra atliekama kitu pripažintų organizacijų pateikiamų vertinimų analize tai analizuojami jų pateikiami šalies konkurencingumo veiksniai, interpretuojami jų vertinimai. Daugelyje šalių nustatant konkurencingumą apibūdinančius veiksnius, teoriniu pagrindu pasirinktas gerai žinomas M. E. Porter „deimanto“ modelis (Porter 1998). Taip pat yra šalių, kurios naudoja savo siūlomą veiksnių struktūrą. Pavyzdžiui, Airijos Nacionalinio konkurencingumo tarybos atliekamo šalies konkurencingumo vertinimo pagrindas - konkurencingumo piramidè (1.1 pav.).

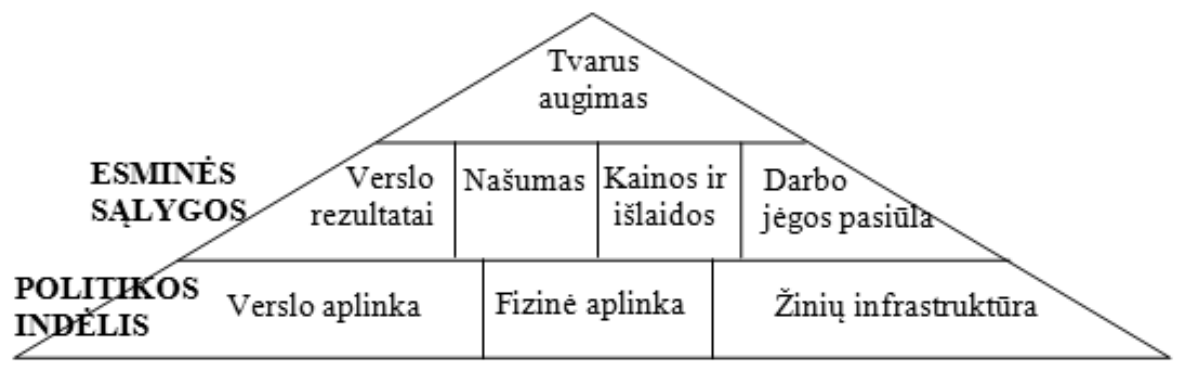

1.1 pav. Konkurencingumo piramidè

Fig. 1.1. The competitiveness pyramid Šaltinis: National Competitiveness Council (Ireland) (2010)

Piramidès viršuje, kaip konkurencingumo sèkmès rezultatas praeityje, ịvardintas tvarus gyvenimo standartu augimas. Žemesniame lygmenyje pateiktos esminès sąlygos siekiant konkurencingumo - verslo rezultatai (prekyba, investicijos), našumas, kainos ir išlaidos bei darbo jègos pasiūla. Šie veiksniai gali būti suprantami kaip esamo šalies konkurencingumo rodikliai. Žemiausiame piramidès lygmenyje įvertinamas politikos indèlis, apimantis tris svarbiausias sritis sie- 
kiant konkurencingumo ateityje - verslo aplinką (apmokestinimas, reguliavimas, finansinis ir socialinis kapitalas), fizinę (transportas, energetika, informacinès ir telekomunikacinès technologijos, būstas) ir žinių (ugdymas, išsilavinimas ir mokymasis visą gyvenimą, moksliniai tyrimai ir plètra) infrastruktūrą. Kai kurių šalių nacionalinio konkurencingumo tarybos (Armėnijos, Kroatijos) pasinaudojo Airijos patirtimi ir savo vertinimo metodikose naudoja panašias šalies konkurencingumą nusakančių veiksnių struktūras. Tačiau nei Airija nei kitos jos patirtimi pasinaudojusios šalys nepateikia tvirto teorinio pagrindo paaiškinančio vertinimui naudojamų veiksnių pagrịstumą.

Apibendrinant šaliu patirti, galima pažymèti, kad pastaraisiais dešimtmečiais šalyse suintensyvejo įvairius skirtingus interesus atstovaujančių ir svarbų patariamaji vaidmenį sprendimų prièmimo procese vaidinančių nacionalinio konkurencingumo tarybų steigimas. Dèl palyginti neilgos tokių tarybų veiklos istorijos dar nèra tvirtai susiformavusios jų veiklos gairès, tačiau viena svarbi joms tenkanti ir tarp visų šalių jas vienijanti funkcija aiški jau šiandien. Tai - šalies konkurencingumo vertinimas ir rekomendacijų atitinkamiems subjektams pateikimas.

Menka minètų institucijų patirtis sąlygoja tai, kad kiekvienoje analizuotoje šalyje veikianti nacionalinio konkurencingumo taryba pateikia (jeigu pateikia) skirtingą šalies konkurencingumo sampratos suvokimą ir vertinimams naudoja skirtingus šalies konkurencingumą apibūdinančius veiksnių rinkinius. Dalis šalių analizuoja gerai žinomų organizacijų pateikiamus vertinimus (Armėnija, Egiptas, Kroatija) ar atlieka vertinimus kuriu pagrindas M. E. Porter „deimanto“ modelis (Armènija, Jordanija), tačiau kita dalis - naudoja tvirto teorinio pagrindo neturinčias vertinimo metodikas (Airija, Čekija, Kroatija). Tokių tvirtai nepagrįstų vertinimų rezultatų pagrindu suformuoti prioritetai, tikslai ir už sprendimų prièmimą atsakingiems subjektams pateiktos netikslios, bendro pobūdžio, konkrečių sprendimų ir pagrịstumo stokojančios rekomendacijos kelia neefektyvių sprendimų prièmimo grèsmę.

Šalių patirties analizė leidžia konstatuoti, kad nacionalinio konkurencingumo tarybų vaidmuo yra svarbus šalies konkurencingumo skatinimo sprendimu prièmimo procese, tačiau dèl palyginti trumpos jų veiklos istorijos šiandien joms trūksta priemonių, suteikiančių galimybes efektyviai atlikti savo funkcijas - galimai tiksliau ịvertinti konkurencingumą ir už galutinių sprendimų prièmimą atsakingiems subjektams pateikti pagrịstas ir efektyvios strategijos sukūrimą lemiančias rekomendacijas. 


\section{3. Šalies konkurencingumo sampratos raida}

Dauguma mokslininku (Reinert 1995; Krugman 1996; Cho ir Moon 2002; Bienkowski 2009) sutinka, kad šalies konkurencingumas, keliant klausimus, kodèl vienos šalys yra sẻkmingesnès už kitas ir ką daryti, kad spartètų ekonominis augimas, buvo pradètas nagrinèti dar XVI amžiuje. Nuo to laiko konkurencingumo samprata makro lygmenyje metai iš metų kito.

Atlikta mokslinès literatūros analizè leidžia išskirti tris požiūrius, skirtingai aiškinančius šalies konkurencingumą tam tikrais laikotarpiais (1.2 pav.). Išsami šių požiūrių ir juos atstovaujančių teorijų bei mokyklų analizė atliekama trijų laikotarpių perspektyvoje: XVI-XVIII a., XVIII-XX a. ir XX-XXI a.

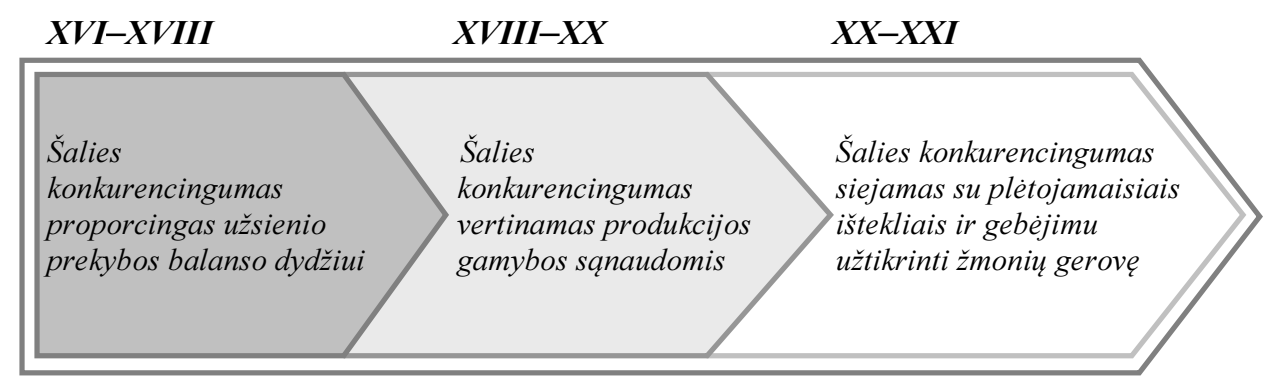

1.2 pav. Šalies konkurencingumo sampratos raida

Fig. 1.2 The evolution of the national competitiveness conception Šaltinis: sudaryta autorès

XVI-XVIII a. laikotarpiu Europoje buvo paplitusios merkantilistų idejos (Humphrey 1999; Reiljan et al. 2000; Cho ir Moon 2002; Čiegis 2006), kuriu raštu pradžia laikomas A. Serra $1613 \mathrm{~m}$. išleistas traktatas, atskleidžiantis, kaip veikia užsienio mainų mechanizmas ir kokị poveiki ekonominès sąlygos turi užsienio prekybai bei pinigu pasiūlai. Nors paprastai, nagrinejjant šalies konkurencingumo aiškinimu pradžią, minimos merkantilistų idejjos bendrai, tačiau derètu kalbėti apie ankstyvaji ir vèlyvaji merkantilizmo etapus atskirai. Ankstyvasis etapas dar vadinamas monetarizmu arba pinigų balanso merkantilizmu buvo aktualus iki XVI a. vidurio, kai prekybiniai ryšiai tarp šalių dar buvo silpnai išplètoti. Ankstyvieji merkantilistai, atsieję pinigų cirkuliaciją nuo gamybos, pagrindine pinigu trūkumo problema laikẻ aukso ir sidabro išvežimą iš šalies. Todèl valstybès iždo pildymo uždavinys buvo akivaizdus: skatinti pinigų įvežimą ị šali ir riboti jų išvežimą. Buvo manoma, kad ekonominių siekių tikslas - tautos galybè, o pats svarbiausias tos galybès elementas yra auksas. Taigi, auksas neretai tapatintas su turtu apskritai, o prekyba laikyta kova už auksą. Tačiau prasidejus XVII amžiui toki aukso garbinimą pamažu pakeitè naujos koncepcijos, pabrèžiančios 
prekybą kaip svarbiausią nacionalinio gyvybingumo šaltinį. Vieno iš vėlyvojo merkantilizmo atstovų T. Mun (1630) nuomone, didesnis turtas ir pinigu kiekis šalyje gali būti pasiektas ne uždraudžiant juos išvežti, o aktyviai plètojant užsienio prekybą.

Merkantilistų požiūrio svarbiausius principus M. Blaug (1997) apibūdina tokiais teiginiais:

- turtą sudaro auksas ir brangenybės;

- užsienio prekybos reguliavimas siekiant užtikrinti, kad kuo daugiau aukso ir sidabro patektų i šalį;

- parama pramonei importuojant pigias žaliavas;

- lengvatiniai tarifai importuojamoms pramoninėms prekèms;

- eksporto, ypač baigtinių gaminių, skatinimas;

- gyventojų skaičiaus augimas, kaip veiksnys leidžiantis palaikyti žemą darbo užmokesčio lygi.

Tarp merkantilistų buvo tokių, kurie suprato, kad šalies turtą sudaro ne tik aukso ir sidabro atsargos, bet ir žemè, pastatai bei ịvairių rūšių vartojimo gèrybès. Tačiau didelè dauguma jų vis dèlto tikejjo, kad svarbiausia yra pinigai, nes būtent jie skatina prekybą. Konkurencingesnèmis buvo laikomos tos šalys, kurių eksportas viršijo importą. Taigi, merkantilizmo atstovai šalies konkurencingumą vertino atsižvelgdami ị prekybos apimtis ir jos ekonominę naudą. Jie palaikè protekcionistinę politiką, kurios esmè - eksporto skatinimas ir importo ribojimas, siekiant palaikyti nuolatini prekybos balanso perteklių. Tačiau idèją, kad aktyvus tarptautinès prekybos balanso perteklius yra vienintelis šalies turto šaltinis, vèliau sukritikavo klasikinès ekonomikos atstovai.

XVIII-XX a. apima klasikinès ekonomikos pletros etapus nuo antrojo iki paskutiniojo - ketvirto. Vienas iš žymiausių klasikinès ekonomikos atstovų yra A. Smith (1776), kuris nustate keturis sąnaudas lemiančius veiksnius - šalis, kapitalas, gamtiniai ištekliai ir darbo jèga - ir palaipsniui pakeitè merkantilizmo periodu gyvavusią ,kiek vienas laimi, kitas pralaimi“ (Zero-sum) teoriją (Cho ir Moon 2002; Garelli 2006; Bienkowski 2009). Jis prieštaravo bet kokiems užsienio prekybos suvaržymams ir teigè, kad prekybos laisvė naudinga visų visuomenès narių interesams (Čiegis 2006). Klasikinès teorijos pagrindas yra laisva tarptautinè prekyba, kuri naudinga abiem šalims, kadangi leidžia didinti gamybos efektyvumą. Esant prekybos laisvei ir laisvai konkurencijai, šalis gamins tas prekes, kurias galès pagaminti mažiausiomis sąnaudomis. Taip susidarys geriausias tarpvalstybinis darbo pasidalijimas, kai kiekviena valstybè turès naudos, nes, esant laisvai konkurencijai, bus galima pirkti pigiausiai, o savo šalies produktus, kurie gaminami natūraliomis sąlygomis mažiausiomis sąnaudomis - parduoti brangiausiai. A. Smith remdamasis absoliutaus pranašumo idejja išplètojo prekybos privilegijų supratimą - šalis absoliutų pranašumą igauna tarptautinei rinkai pateikdama produkciją, pagamintą kiek įmanoma mažiausiomis sąnaudomis. 
Eksportuodama tokią produkciją šalis tampa konkurencinga tos produkcijos atžvilgiu.

Kitas klasikinès ekonomikos atstovas D. Ricardo (1817) išplètojo A. Smith idejjas ir sukūrè santykinio pranašumo teoriją (Reiljan et al. 2000; Cho ir Moon 2002; Garelli 2006). B. Taner et al. (2000) teigia, kad būtent ši teorija ir vèlesnès, sukurtos jos pagrindu, yra tarptautinio konkurencingumo makro lygmenyje sampratos atsiradimo pradžia. Santykinio pranašumo teorija, atskleisdama prekybos naudą esant skirtingoms santykinèms produkcijos sąnaudoms tarp šalių, plačiau apibūdina kaip šalys turètų konkuruoti tarpusavyje. Eksportuojama ta produkcija, kuri pagaminta santykinai efektyviau panaudojant išteklius ir importuojama ta, kuri dèl didesnių išlaidų santykinai yra brangesnè. Tradicinès tarptautinès prekybos teorijos priklauso nuo santykinio pranašumo koncepcijos, akcentuojančios specializacijos idèją, kurią vẻliau išplètojo E. Heckscher ir B. Ohlin.

Su Heckscher-Ohlin (1920) teorija yra tapatinamas neoklasikų požiūris ị šalies konkurencingumą (Best 1993; Coldwell 2000; Nurbel 2007). Ši teorija teigia, kad šalis gamina ir eksportuoja tą produkciją, kuriai pagaminti naudojami gausūs toje šalyje gamybos veiksniai, taigi konkurencingumas siejamas ne tik su produkcijos pirkimo ir pardavimo santykiais, bet ir su kova dèl ribotų ištekliu pasisavinimo. Vèliau buvo suabejota dèl šios teorijos empirinio pritaikomumo (Kwok ir Yu 2005): W. W. Leontief (1953) analizavo JAV užsienio prekybos duomenis ir nustatè, kad imliausia kapitalui šalis pasaulyje eksportuoja darbui imlią produkciją, o importuoja tą, kuri yra imli kapitalui. Šis rezultatas vadinamas Leontief paradoksu, po kurio pateikimo santykiniu pranašumu grindžiami prekybos procesai toliau buvo analizuojami vis kitais aspektais.

Pagal S. Garelli (2006), daugiaaspektei šalies konkurencingumo sampratai, be jau paminètų teorijų, reikšmingos įtakos turèjo ir XIX amžiuje atsiradęs marksizmas, kurio atstovai akcentavo sociopolitinès aplinkos įtaką ekonomikos plètrai bei sociologas M. Weber (1905), nustatęs ryši tarp vertès, religinių įsitikimų ir šalių ekonominès situacijos. Pasak R. Čiegio (2006), M. Weber, nagrinèdamas ryši tarp socialinès minties ir ekonominès veiklos, ypač tarp kalvinistiškojo protestantizmo ir kapitalistinio ekonominio gyvenimo, priešingai nei K. Marx, kuris pabrèžè ryši tarp ekonominių sąlygų ir socialinès kaitos modelių, teigè, kad kaitos varomoji jèga gali būti kitos jègos, tokios kaip tradicija ir religija. Pagal M. Weber, protestantų doktrinos ragino žmogų nusižeminti ir susitelkti ties žemiškais reikalais bei savo pareigomis. Toks atsidavimas kasdieniam žemiškam darbui ir didžiavimasis juo lèmè didesnị našumą, o tai reiškè didesnį uždarbį. Taip pat protestantiškose visuomenèse būdingas didesnis taupumas, kas reiškia, kad jos atstovai mažiau vartojo. Todèl protestantiškos visuomenès, kuriose kapitalo kaupimo laipsnis buvo daug didesnis nei katalikiškose, pastarujų atžvilgiu buvo konkurencingesnès. 
Jau ankstyvoje XX a. pradžioje suabejota gamybos sąnaudų lemiama reikšme ir pradèta ieškoti kitų ekonominę plètrą lemiančių veiksnių. $1961 \mathrm{~m}$. S. Linder pateikè šalių panašumo teoriją (Cho ir Moon 2002; Čiburienè ir Zaharieva 2006), kuri teigia, kad prekyba priklauso ne nuo produkcijos gamybos sąnaudu, bet nuo poreikių ir skonio panašumų, t. y. nuo paklausos sąlygų šalyse ị kurias eksportuojama produkcija. Pagrindinis veiksnys, nulemiantis vyraujančius poreikius yra santykinės pajamos. R. Vernon (1966) santykini pranašumą susiejo su produkto gyvavimo ciklu bei akcentavo tokius svarbius veiksnius kaip inovacijos ir technologijos.

Analizuojant šalies konkurencingumui tiesioginę ar numanomą reikšmę turèjusių ekonomikos teorijų mokyklas svarbu paminèti ir keinsistinę ekonomikos teoriją (Reiljan et al. 2000; Martin 2003). Ši teorija, kurios pradininkas yra J. M. Keynes (1936), gali būti apibūdinama kaip visuminès paklausos ir užimtumo trumpalaikès dinamikos teorija, pagrịsta lūkesčiais, kad tai įtakoja investavimą ir vartojimo elgseną. Bendros šalies pajamos tai suvartojimo, investicijų, vyriausybès išlaidų bei eksporto (atėmus importą) suma. Nacionalinès ekonomikos eksporto pagrindas - konkurencijos mastas ir eksporto pajamos bei ju itaka vidaus sektoriams, suvartojimui ir investicijoms. Ypač svarbų vaidmenį keinsistų teorijoje vaidina vyriausybė. Jų supratimu, rinkos mechanizmas negali užtikrinti visiško užimtumo, todèl tuo turi pasirūpinti vyriausybè. Taip pat, keinsistai mané, kad nestabili paklausa investicijoms yra ekonomikos nestabilumo šaltinis ir vyriausybès išlaidos gali būti kaip situacijos ištaisymo priemonè. Šalių konkurencingumui vyriausybès efektyviai vykdoma ekonominè politika yra itin svarbi (Thurow 1992).

Prie šalies konkurencingumo tapatinimo su plètojamaisiais ištekliais reikšmingai prisidejjo (Garelli 2006): J. Schumpeter (1942), kuris akcentavo kad progresas yra nestabilumo rezultatas, palaikantis inovacijų ir technologijų tobulejimą; R. Solow (1957), kuris analizavo veiksnius, lemiančius ekonomikos augimą tam, kad pabrèžtų mokslo bei technologinių inovacijų svarbą; A. P. Sloan (1963) ir P. Drucker (1969), kurie plètojo valdymo koncepciją, kaip pagrindini konkurencingumo veiksnį bei N. Negroponte (1995) ir kiti šiuolaikinès ekonomikos atstovai, kurie toliau gilinasi ir tobulina ,žinių“, kaip naujausio konkurencingumo veiksnio, sąvoką. Galiausiai, siekdamas integruoti visas ankstesnes idejjas, M. E. Porter (1998) pateikè sistemini nacionalinio konkurencingumo „deimanto“ modeli, pagal kuri konkurencingumas suvokiamas kaip ,šalies gebejjimas sukurti tokią aplinką, kuri igalintų ịmones tobulèti ir diegti naujoves greičiau negu užsienio konkurentai““. Autorius išplète konkurencingumo sąvoką, teigdamas, kad ji apima daugybę veiksnių ir išskyrè našumą, kaip pagrindą siekiant nacionalinès sèkmès.

XX amžiuje šalies konkurencingumo samprata tapo neatsiejama nuo žmogaus gerovès. Dauguma mokslininkų (Fagerberg 1988; Landau 1992; Oughton ir 
Whittam 1997; Aiginger 2006) kaip konkurencingą šalị įvardina tą, kuri užtikrina savo gyventojams gyvenimo gerovę: aukštą pragyvenimo lygi, kokybišką išsilavinimą, tinkamą socialinę apsaugą, pasirinkimo laisvę ir pan. Ir jeigu XVI a. gyventojai buvo suvokiami kaip vienas iš veiksnių, užtikrinančių visos šalies turtingumą, tai dabar jų gerovè yra svarbiausias kiekvienos šalies tikslas.

\section{4. Šalies konkurencingumo sampratos interpretacijų analizè}

Atlikta šalies konkurencingumo sampratos raidos analizė atskleidè jos kaitą laiko atžvilgiu, kuri lèmè, kad šiandien kiekvienam šią sąvoką vartojančiam ji turi skirtingą reikšmę. Vieni šalies konkurencingumą mato kaip makroekonominį reiškinį, kurị lemia tokie elementai kaip valiutų kursai, palūkanų normos ir valstybès biudžeto deficitas; antri šalies konkurencingumą sieja su gausiais šalies turimais ištekliais; treti palaiko idèją, kad šalies konkurencingumas priklauso nuo užsienio prekybos sèkmès; ketvirti šalies konkurencingumą tapatina su šalies našumu; penkti teigia, kad šalis konkurencinga, jei geba savo gyventojams sukurti gerovę. Nemažai autorių pateikia daugiaaspekčius, ne vieną paminètą aspektą apimančius apibrèžimus. Taip pat yra tokių, kurie konkurencingumo sąvokos vartojimo makro lygmenyje iš vis nepripažįsta. Vienas žinomiausių kritikų šalies konkurencingumo sąvokos atžvilgiu yra JAV ekonomistas P. Krugman (1996), kuris teigia, kad ši sąvoka naudojama šalies kontekste yra sunkiai suprantama ir visus apėmusi jos vartojimo manija yra pavojinga, nes gali iškreipti priimamus sprendimus.

Toks skirtingų aiškinimu gausumas nesuteikia galimybès susidaryti konkretaus vaizdo ką šalies konkurencingumo sąvoka iš tikrujjų reiškia ir kelia poreiki patikslinti jos apibrèžimą. Tam tikslui atliekama mokslinèje ir analitinèje literatūroje pateikiamų šalies konkurencingumo apibrèžimų analizè, ieškant juos vienijančių pagrindinių aspektų, pagal kuriuos būtų galima išskirti vyraujančius požiūrius (1.3 lentelè).

1.3 lentelè. Šalies konkurencingumo apibrèžimai

Table 1.3. The definitions of the national competitiveness

\begin{tabular}{|l|l|l|}
\hline \multicolumn{1}{|c|}{ Autorius } & \multicolumn{1}{|c|}{ Apibrèžimas } & Pagrindiniai aspektai \\
\hline $\begin{array}{l}\text { Klemetti } \\
(1989)\end{array}$ & $\begin{array}{l}\text { Šalies gebėjimas konkuruoti dėl eksporto rin- } \\
\text { kų, palaikyti ekonomikos augimą ir užtikrinti } \\
\text { užimtumą }\end{array}$ & $\begin{array}{l}\text { Užsienio prekyba, } \\
\text { ekonomikos augimas, } \\
\text { užimtumas }\end{array}$ \\
\hline $\begin{array}{l}\text { Landau } \\
(1992)\end{array}$ & $\begin{array}{l}\text { Gyventojų gyvenimo lygio augimas kartu už- } \\
\text { tikrinant santykinai vienodos gerovès paskir- } \\
\text { stymą, suteikiant galimybę dirbti visiems, ku- }\end{array}$ & $\begin{array}{l}\text { Gyvenimo standartai, } \\
\text { užimtumas }\end{array}$ \\
\hline
\end{tabular}


1.3 lentelès pabaiga

\begin{tabular}{|c|c|c|}
\hline Autorius & Apibrèžimas & Pagrindiniai aspektai \\
\hline & $\begin{array}{l}\text { rie gali ir nori dirbti ir igyvendinant tai neken- } \\
\text { kiant ateinančių kartu gyvenimo standartams }\end{array}$ & \\
\hline $\begin{array}{l}\text { Dollar ir } \\
\text { Wolff (1993) }\end{array}$ & $\begin{array}{l}\text { Sėkmė tarptautinėje prekyboje ir kartu gebė- } \\
\text { jimas palaikyti aukštas gyventojų pajamas, } \\
\text { užtikrinti aukštą darbo užmokesti }\end{array}$ & $\begin{array}{l}\text { Našumas, } \\
\text { gyvenimo standartai }\end{array}$ \\
\hline $\begin{array}{l}\text { Straubhaar } \\
(1994)\end{array}$ & $\begin{array}{l}\text { Salies gebejjimas pasiūlyti patrauklias sąlygas, } \\
\text { susijusias su kintančių sąnaudų pranašumu }\end{array}$ & Patrauklumas \\
\hline $\begin{array}{l}\text { Kitzmantel } \\
(1995)\end{array}$ & Visuotinè gerovė & Visuotinė gerovė \\
\hline $\begin{array}{l}\text { Trabold } \\
(1995)\end{array}$ & $\begin{array}{l}\text { Gebejjimas parduoti, pritraukti, prisitaikyti ir } \\
\text { uždirbti }\end{array}$ & $\begin{array}{l}\text { Užsienio prekyba, } \\
\text { patrauklumas, lanks- } \\
\text { tumas, gyvenimo } \\
\text { standartai }\end{array}$ \\
\hline $\begin{array}{l}\text { Gough } \\
(1996)\end{array}$ & $\begin{array}{l}\text { Šalies gebejjimas užtikrinti aukštas ir kylančias } \\
\text { pajamas šalies gyventojams, kai šalies įmonès } \\
\text { bando atremti užsienio konkurenciją }\end{array}$ & $\begin{array}{l}\text { Užsienio prekyba, } \\
\text { aukšti gyvenimo } \\
\text { standartai }\end{array}$ \\
\hline $\begin{array}{l}\text { Fagerberg } \\
(1996)\end{array}$ & $\begin{array}{l}\text { Šalies gebejjimas dabar ir ateityje užtikrinti } \\
\text { savo gyventojams aukštesnius gyvenimo stan- } \\
\text { dartus negu kitose šalyse }\end{array}$ & $\begin{array}{l}\text { Aukšti gyvenimo } \\
\text { standartai }\end{array}$ \\
\hline $\begin{array}{l}\text { Orlowski } \\
(1997)\end{array}$ & Šalies gebejjimas parduoti & Užsienio prekyba \\
\hline $\begin{array}{l}\text { Oughton ir } \\
\text { Whittam } \\
(1997)\end{array}$ & $\begin{array}{l}\text { Ilgalaikis našumo augimas ir dèl to kylantys } \\
\text { gyvenimo standartai kartu su augančiu ar pa- } \\
\text { laikomu pilnu užimtumu }\end{array}$ & $\begin{array}{l}\text { Našumas, gyvenimo } \\
\text { standartai, užimtumas }\end{array}$ \\
\hline Porter (1998) & $\begin{array}{l}\text { Našumas (imonių pajègumas pasiekti aukšto } \\
\text { lygio našumą - ir ji laikui bėgant padidinti) }\end{array}$ & Našumas \\
\hline $\begin{array}{l}\text { Figueroa } \\
\text { (1998) }\end{array}$ & $\begin{array}{l}\text { Gebejjimas užimti ir išlaikyti rinkos dali tarp- } \\
\text { tautinèje rinkoje }\end{array}$ & Užsienio prekyba \\
\hline $\begin{array}{l}\text { Aiginger } \\
(2006)\end{array}$ & Šalies gebejjimas sukurti gerovę & Gerovè \\
\hline $\begin{array}{l}\text { Bienkowski } \\
\text { (2009) }\end{array}$ & $\begin{array}{l}\text { Šalies gebejjimas santykinai greitai augti ilguo- } \\
\text { ju periodu, kad ekonomika būtų pajègi prisi- } \\
\text { taikyti, siekiant efektyviau bendrauti su besi- } \\
\text { vystančia pasaulio ekonomika }\end{array}$ & $\begin{array}{l}\text { Augimas, lankstu- } \\
\text { mas, } \\
\text { užsienio prekyba }\end{array}$ \\
\hline $\begin{array}{l}\text { PEF } \\
(2013)\end{array}$ & $\begin{array}{l}\text { Institucijų, politikos ir veiksnių rinkinys api- } \\
\text { būdinantis šalies našumo lygi }\end{array}$ & Našumas \\
\hline $\begin{array}{l}\text { TVPI } \\
(2013)\end{array}$ & $\begin{array}{l}\text { Veiksniai ir politika, formuojantys šalies ge- } \\
\text { bėjimą sukurti ir palaikyti tokią aplinką, kuri } \\
\text { suteikia galimybę įmonèms kurti didesnę vertę } \\
\text { ir užtikrina gerovę šalies gyventojams }\end{array}$ & $\begin{array}{l}\text { Našumas, } \\
\text { gerovè }\end{array}$ \\
\hline
\end{tabular}

Šaltinis: sudaryta autorès 
Atsižvelgiant ị dažniausiai, apibrěžiant šalies konkurencingumą, minimus aspektus, išsamios mokslinès literatūros analizès reikalauja tokie trys labiausiai paplitę požiūriai:

- Šalies konkurencingumas - tai sėkminga šalies užsienio prekyba;

- Šalies konkurencingumas - tai šalies našumas;

- $\quad$ šalies konkurencingumas - tai gebejjimas užtikrinti šalies gyventojų gerovę.

Šalies konkurencingumas - sėkminga užsienio prekyba. Šalies konkurencingumo sampratos raidos analizè atskleide, kad šio požiūrio ištakos siekia dar merkantilistų idejų laikus, kai šalies konkurencingumas vienareikšmiškai buvo suvokiamas kaip šalies laimejjimai užsienio prekyboje. Šių laikų tokio požiūrio šalininkai (Koskivaara 1989; Klemetti 1989; Fagerberg 1996; Figueroa 1998), šalis prilygindami įmonèms palaiko idèją, kad jos konkuruoja tarpusavyje dèl tarptautinių rinkų. Tokiu atveju, šalies konkurencingumas didejja augant jos eksporto apimtims pasaulinejje rinkoje.

Vertinant sėkminga užsienio prekyba pagrịsto konkurencingumo supratimą, tikslinga išskirti dvi atskiras konkurencingumo kryptis (McFetridge 1995; Berger 2008): konkurencingumas, kurị lemia kaina ir konkurencingumas, kurị lemia kiti veiksniai. Šalių įmonès tarpusavyje gali konkuruoti vartotojams pateikdamos produkciją kuo mažesnėmis kainomis, kurias užtikrinti gali mažos produkcijos gamybos sąnaudos arba šalies valiutos kurso korekcijos. A. Boltho (1996) netgi teigia, kad pageidaujamas tarptautinio konkurencingumo laipsnis gali būti apibūdinamas kaip valiutos kurso lygis, kuris, kartu su kitais tinkamais vidaus politikos sprendimais, užtikrina vidinị ir išorinị balansą. Kita vertus, sėkmingai parduodama gali būti ir produkcija, kurios kaina yra palyginti aukšta. Čia svarbūs tampa kiti veiksniai, tokie kaip kokybè, vartotojų poreikiu atitikimas, ivvaizdis. Kokybinių veiksnių svarbą pabrèžiantys analitikai (pvz. Durand et. al. 1998) atkreipia dèmesị i investicijų svarbą technologijoms, kapitalui, vadybos įgūdžiams, kurie itin reikalingi ịmonių konkurencingumui plètoti (Vilpišauskas 2004).

Tačiau, toks šalių tapatinimas su įmonèmis, teigiant, kad jos tarpusavyje konkuruoja dèl rinkų, mokslininkų yra itin kritikuojamas (Krugman 1996; Porter 1998). P. Krugman (1996) teigia, kad nors dažnai kalbama apie šalių prekybą ir konkurenciją, iš tikrųų prekiauja ir konkuruoja tik įmonès, todèl netikslu kalbèti apie „JAV korporaciją“, nes priešingai nei konkuruojančioms įmonèms, tarptautinè prekyba yra naudinga visoms šalims. Tarptautiné prekyba (ir importas ir eksportas) leidžia įmonèms išnaudoti santykinius kiekvienos šalies pranašumus plètojant darbo pasidalijimą ir specializaciją, ji sudaro sąlygas augti visų šalių ekonomikai ir gerovei. Garsus ekonomistas taip pat pažymi, kad kai kuriose šalyje eksportas užima labai mažą BVP dali, kas reiškia, kad toms šalims žymiai svarbesnè yra vidaus, o ne išorès paklausa. 
Pasaulio šalių patirtis taip pat rodo, kad aptariamo požiūrio šalininkai didelị dėmesị kreipdami ị užsienio prekybos balansą rizikuoja būti suklaidintais. Teigiamas užsienio prekybos balansas gali būti ir valstybès silpnybiu požymis, o deficitas - stiprybè. Pasak D. G. McFetridge (1995), deficitas gali būti nulemtas fiskalinès ar monetarinès politikos, o ne vidaus įmonių nesėkmès bandant atitikti produkcijos tarptautinius standartus. Pavyzdžiui, XX a. devintajame dešimtmetyje ịsiskolinusių Lotynų Amerikos ir Afrikos valstybių užsienio prekybos balansas buvo teigiamas, tačiau jų konkurencingumas buvo žemas.

Vis tik pagrindinis nepalaikančiųų šalies konkurencingumo kaip sèkmingos užsienio prekybos sampratos argumentas yra toks: dèl siekio sèkmingai konkuruoti tarptautinejje rinkoje mažinamos gaminamos produkcijos sąnaudos arba keičiamas valiutos kursas prisideda prie gyventojų perkamosios galios mažejimo ir taip pablogina jų gyvenimo standartus. Ši argumentą pagrindžia ir šalių praktikos pavyzdžiai (Porter 1990): praeito amžiaus pabaigoje Vokietija ir Japonija turèdamos tvirtas valiutas ir kylančių kainų laikotarpi sugebejo pasieké ženklius laimèjimus šalies gyventojų gyvenimo standartų augime; Šveicarija ir Italija taip pat demonstravo nuolat augančių šalies pajamų tendencijas nors pirmoji nepasižymejjo tvaria užsienio prekyba, o antrosios prekybos balansas buvo neigiamas; Indija ir Meksika dar ir šiandien turi mažus atlyginimus ir žemas darbo jègos sąnaudas, tačiau nei vienos nei kitos negalima pavadinti konkurencingomis.

Pasitelkdami tvirtus argumentus prieš tai aptarto požiūrio kritikai teigia, kad šalies konkurencingumas - tai šalies našumas. Tokio požiūrio šalininkai mano, kad būtent šalies ekonominiai laimejjimai sukuria materialų pagrindą sèkmingai visuomenès plètrai ir kiekvieno individualaus žmogaus gyvenimo standartų didèjimui (Porter 1990, 1998; McFetridge 1995; Budd ir Hirmis 2004).

M. E. Porter (1990) teigia, kad esminis šalies tikslas - sukurti aukštus ir vis augančius gyvenimo standartus šalies gyventojams, o galimybẻ tai padaryti priklauso nuo šalyje veikiančių įmonių pajègumo pasiekti aukšto lygio našumą ir ji laikui bėgant padidinti. M. E. Porter (1990) suvokiama gerovè yra tokia, kurią galima sukurti atliekant ekonominę veiklą, o ne taip vadinama „paveldèta“gaunama naudojant turimus gamtos išteklius. Autorius taip pat pabrěžia šalyje veikiančiu įmonių nuolatinio tobulèjimo svarbą.

H. Trabold (1995), palaikydamas idèją, kad svarbiausia šalies siekiamybe laikomas jos gebejjimas uždirbti, pateikia hierarchinę šalies konkurencingumo sistemą (1.3 pav.), kurioje tokie aspektai kaip gebejimas parduoti (eksportuoti), gebejjimas patraukti ir gebejjimas prisitaikyti įvardijami kaip konkurencingumą lemiantys veiksniai (Reiljan et al. 2000).

Aptariamo požiūrio šalininkai kalbẻdami apie gyvenimo gerovę ją suvokia išskirtinai ekonomiškai - tai materialinèmis vertybèmis ir pinigine išraiška ịvertinamas gyvenimo lygis. Siekiant nustatyti tokią gyvenimo gerovę, o kartu ir šalies konkurencingumą dažniausiai yra pasitelkiamas BVP tenkančio vienam gy- 
ventojui rodiklis arba vertinamas jo augimo tempas. Būtent toks šalies gyventoju gerovès vertinimas išskirtinai dėmesị sutelkiant tik ekonomikai, pamirštant socialines ir ekologines problemas daro ši požiūrị netiksliu.

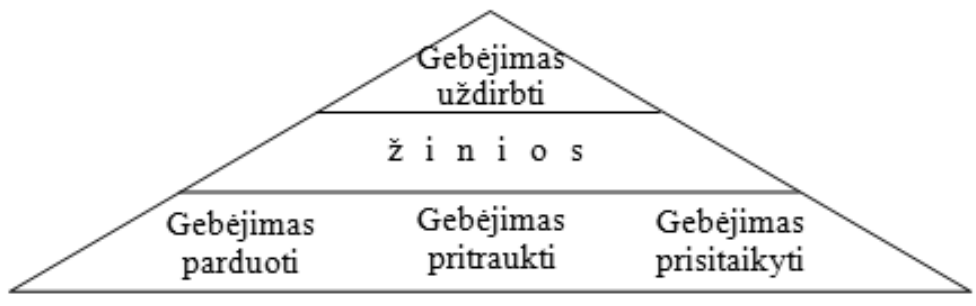

1.3 pav. Šalies konkurencingumo sistema

Fig. 1.3. The system of the national competitiveness

Šaltinis: Reiljan et al. (2000)

Kritikai (Garelli 1997; Dunford 2005; Aiginger 2006; Berger 2008) pažymi, kad BVP, tenkantis vienam gyventojui, kaip šalies gerovès, o kartu ir konkurencingumo, rodiklis atskleidžia šalies gyventojų galimybę apsirūpinti ịvairiais materialiais daiktais, tačiau i ji nepatenka nematerialūs, neperkami, bet žmogui taip pat labai svarbūs dalykai. Aukštas šalies BVP pats savaime dar negarantuoja socialinès lygybès šalyje ir, tuo labiau, nebūtinai byloja apie dideli jos konkurencingumą. Aukštas BVP gali būti didelio nusikalstamumo, šalyje klestinčios juodosios rinkos padarinys.

S. Lall (2001) nuomone, jei šalies konkurencingumas interpretuojamas kaip gebejjimas sukurti pajamas ar paskatinti našumo augimą, tuomet tai yra šalies plètros arba augimo strategija ir nèra prasmès atskirai svarstyti nacionalinio konkurencingumo klausimo. Kita vertus, autorius pabrež̌ia, kad ekonomikos pažangai apibūdinti šiandien yra reikalinga platesnè samprata: našumą lemiančiu veiksnių analizè ir toliau turi išlikti kertiniu ekonomikos plètros studijų klausimu, nes pajamos yra esminis plètros veiksnys, tačiau toks siauras požiūris turi būti praplèstas dèmesį skiriant ir neekonominiams veiksniams.

Šalies konkurencingumas - tai gebejjimas užtikrinti šalies gyventojų gerovę. Analizuojant naujausią mokslinę literatūrą šalies konkurencingumo tema matyti, kad vienas svarbiausių minimų aspektu, netgi ịvardijamas kaip pagrindinis konkurencingumo tikslas (Reiljan et al. 2001; Kovačič 2007), yra šalies gyventoju gerovè. Šis požiūris glaudžiai susijęs su prieš tai aptartu našumo pagrindu aiškinamu požiūriu, tačiau kai kurių mokslininkų (Reiljan et al. 2000; Aiginger 2006) išsakytos mintys skatina ji vertinti atskirai. Reiljan et al. (2000) manymu, bandymai šalies konkurencingumą apibrèžti pasitelkiant tik ekonominius veiksnius yra riboti ir vienašališki. O K. Aiginger (2006) teigia, kad tiksliausia šalies konkurencingumą apibrèžti, kaip jos „gebejjimą sukurti gerovę“, tokiu atveju būtu 
išvengta daug neaiškumų ir nesutarimų. Autorius atremdamas itin plačiai cituojamą P. Krugman kritiką, kad šalies konkurencingumo sąvokos vartojimas yra pavojingas, teigia, kad vienos vietovès konkurencingumas - jei apibūdinamas kaip gebejjimas sukurti gerovę - nebūtinai turi reikšti kliūtis kitos vietovès konkurencingumui, o tai eliminuoja „pavojaus“ esminị elementą tariamai susijusị su sąvoka.

Konkurencija tarp šalių gali būti matoma iš skirtingu pozicijų - konkurencija dèl rinkų, konkurencija dèl investicijų, tačiau pagrindinis bet kurios civilizuotos ir demokratinès valstybès tikslas, pasak J. Reiljan et al. (2001), yra užtikrinti bendrą gyventoju gerovę. O tai gali būti pasiekiama ịvairiais būdais: didinant šalies gamybos efektyvumą, skatinant eksportą, pritraukiant užsienio investicijas, išplečiant efektyvios pramonès veiklą ị užsienį, gerinant aplinkos apsaugą, padidinant socialinę apsaugą ir stabilumą, didinant pasirinkimo laisvę ir asmens tobulejjimo galimybes ir pan. Jei šalis gali pasiūlyti savo gyventojams galimybę gauti darbą (aukštos pajamos) ir socialines garantijas (demokratija, socialinis teisingumas, išsilavinimas ir sveikatos apsauga), tada gali būti teigiama, kad tokia šalis yra konkurencinga.

J. Reiljan et al. (2001) savo mintis pagrindžia pateikdamas hierarchinę socialinio-ekonominio šalies konkurencingumo sistemą (1.4. pav.).

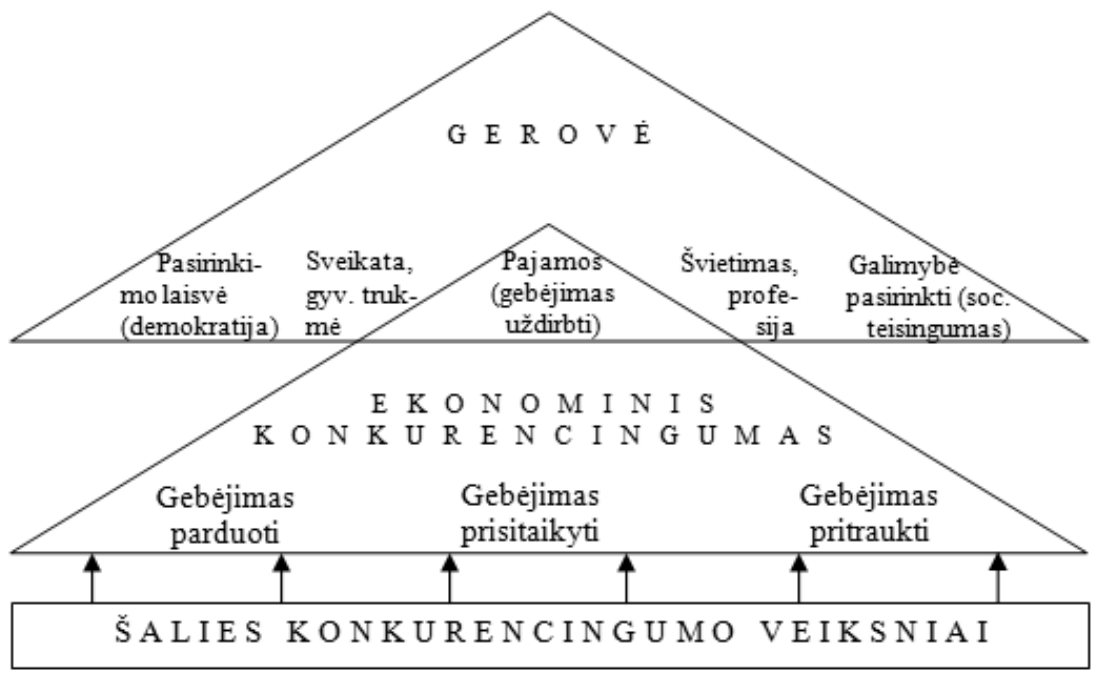

1.4 pav. Socialinio-ekonominio šalies konkurencingumo formavimo sistema

Fig. 1.4. Hierarchical system of the formation of socio-economic competitiveness of a country

Šaltinis: Reiljan et al. (2001)

Sistemoje ekonominis konkurencingumas apibūdinamas pasitelkiant H. Trabold (1995) sistemą, kurioje gebejjimas uždirbti remiasi kitais trimis aspektais - 
gebejjimu parduoti, prisitaikyti ir pritraukti. Nors gebejjimas uždirbti yra vienas svarbiausių šalies konkurencingumo dalių, siūlomoje socialinio-ekonominio konkurencingumo koncepcijoje tai sudaro tik vieną iš šešių dalių. Be ekonominio konkurencingumo taip pat svarbūs yra tokie aspektai kaip laisvè ir galimybè pasirinkti, sveikatos ir švietimo sąlygos.

Teikdamas, kad šalies konkurencingumas - tai jos gebejjimas sukurti gerovę, K. Aiginger (2006) pabrèžia, kad kiekvienas išsamesnis šios koncepcijos pritaikymas turi apimti tokių dviejų svarbių, glaudžiai su gerove susijusių aspektų kaip ekonomikos rezultatų ir ekonomikos proceso vertinimus. Rezultatų konkurencingumas apimdamas elementus, kurie apibūdina gerovę, skirtingai nuo tradicinès gerovès analizès pabrèžia ekonominius tikslus ir konkurencijos rezultatus. Autorius daro prielaidą, kad šalies gerovè pirmiausia koreliuoja su pajamomis, tenkančiomis vienam gyventojui, o kitas svarbus komponentas - užimtumo/nedarbo perspektyvos. Dar platesnis vertinimas apims ir socialinius, ekologinius tikslus ir kitus neekonominius objektus - saugumą, stabilumą, gyvenimo trukmę. Galiausiai, konkurencingos ekonomikos, pasak autoriaus, turi išlaikyti ir tvarumo išbandymus. Ekonomikos proceso konkurencingumas susijęs su gamybos funkcijos metodu, bet skiria daugiau dèmesio kokybinèms sąlygoms, institucijoms, dinamikai, gamybai, inovacijų sklaidai ir kitiems kokybiniams veiksniams.

Tikslumo dèlei, be aptartų trijų labiausiai paplitusių požiūrių i šalies konkurencingumą derètų trumpai pristatyti ir rečiau, tačiau vis tik naudojamus šalies konkurencingumo aiškinimus.

Šalies konkurencingumo kaip gebejjimo pritraukti (Straubhaar 1994; Trabold 1995; Camagni 2002) suvokimas siejamas su šalies gebejjimu pritraukti kiek galima daugiau investicijų. Investuotojai planuodami investuoti visuomet ieškos geriausios tam vietos ir pasirinks tą, kurioje gali tikètis didžiausios investiciju grąžos, todèl šalys tarpusavyje konkuruoja nustatydamos tokias ekonominès aplinkos sąlygas (pvz., mokesčių dydžius), kurios gali pritraukti užsienio investuotojus. Ši požiūrị palaikantieji akcentuoja ne tik finansinį bet ir žmogiškaji kapitalą (Gilmore et al. 2003; Morgan 2004; Siebert 2005) ir tokią konkurenciją tarp šalių vadina lokacine konkurencija. Pasak H. Siebert (2005), lokacinè konkurencija tai konkurencija tarp vietovių, kuri atsiranda per daugybę sąveikos kanalų kapitalo, technologiju ir žmonių judejimą. Autoriaus manymu, kapitalas, technologijos ir aukštos kvalifikacijos darbo jèga tapo tarptautiškai mobilesnè ir jų prieinamumas lemia nemobilių vidaus veiksnių našumą, ịskaitant tradicinę darbo jègą ir žemę. Šalys konkuruoja dèl minètų mobilių veiksnių ir, jei sėkmingai juos pritraukia, padidina savo nemobilių vidaus veiksnių našumą.

Šalies konkurencingumui lankstumo svarbą akcentuojantys (Trabold 1995; Bienkowski 2009) išskiria staigaus reagavimo ir gebejjimo prisitaikyti prie nauju iššūkių, su kuriais šalys susiduria sparčiai besikeičiant aplinkos sąlygoms, besivystant technologijoms ir augant kokybès reikalavimams, būtinybę. T. B. Berger 
(2008) pateikia du po šiuo požiūriu esančius matymus: gebejjimą pritaikyti politines procedūras bei ekonominę sistemą (visuomenès lygmuo) bei gebejjimą prisitaikyti kuriant inovacijas, naujas technologijas (verslo lygmuo). Pirmuoju atveju pabrèžiama laisvos rinkos, atviros ekonomikos, o antruoju - verslininkystès svarba. Pasak M. E. Porter (1996), pralenkti savo konkurentus įmoné galès tik jeigu sukurs ir gebės išlaikyti išskirtinumą, o tai padaryti jai pavyks tik palaikant nuolatini gamybos proceso ar produkcijos tobulinimą. Globaliomis sąlygomis vykstant laisvai prekybai bet koks įmonès turimas pranašumas greitai gali būti nukopijuotas. Konkurentai netruks pasivys tas įmones, kurios nustojo kurti ir diegti naujoves. Todèl vienintelis būdas išlaikyti konkurencingumą yra patobulinti turimą pranašumą, pereiti prie modernesnių produktų ir gamybos procesų.

Nekyla abejonių, kad konkurencinga šalis turi gebėti pritraukti kapitalą bei prisitaikyti prie kintančių aplinkos sąlygų, tačiau kaip atskiri šalies konkurencingumą aiškinantys minèti teiginiai traktuotini kaip per siauri.

Apibendrinant mokslininkų, atstovaujančių dažniausiai sutinkamus skirtingus požiūrius, išsakytas mintis ir siekiant suformuoti šalies konkurencingumo apibrèžimą svarbu atkreipti dèmesị i toliau išdèstytus argumentus.

Nors šalies konkurencingumo sąvoka dèl savo istorinių ištakų šiandien daugumai dar asocijuojasi su šalies užsienio prekybos sėkme, tačiau prieinama sutarimo, kad toks supratimas yra netikslus. Eksportuojanti šalis netampa konkurencingesnè kitos šalies atžvilgiu, nes dèl galimybès išnaudoti santykinius kiekvienos šalies pranašumus plètojant darbo pasidalijimą ir specializaciją tarptautine prekyba sudaro vienodas sąlygas augti visų šalių ekonomikai ir gerovei. Užsienio prekybos apimčių augimas pasiektas mažinant gamybos sąnaudas darbuotojų sąskaita ar koreguojant valiutos kursą užtikrina tvarią ar netgi perteklinę užsienio prekybą, tačiau tuo pat metu mažina šalies žmoniu gyvenimo standartus. Atsižvelgiant ị kiekvienos civilizuotos ir demokratinès valstybès šiandienos siekị - užtikrinti gerovę savo gyventojams, prasmę igauna našumu grindžiama šalies konkurencingumo sąvoka. Žmogaus materialinès gerovès sukūrimas priklauso nuo šalyje sèkmingai veikiančių imonių pajègumo pasiekti aukšto lygio našumą. Svarbu akcentuoti, kad gerove sukuriama vykdant šalyje veiklą, o ne gaunama naudojant jos turimus gamtinius išteklius. Vis dèlto, bandymai šalies konkurencingumą apibrèžti pasitelkiant tik ekonominius veiksnius traktuotini kaip riboti ir vienašališki. Svarbiausiu kiekvienos šalies tikslu turi būti žmogaus bendros gyvenimo gerovés, kuri priklauso ne tik nuo ekonominių, bet ir nuo socialinių bei ekologinių veiksnių, užtikrinimas.

Atsižvelgiant $\mathfrak{i}$ išdèstytus argumentus formuluojamas toks šalies konkurencingumo apibrèžimas:

šalies konkurencingumas - tai šalies gebëjimas pasiekti aukštą našumą ir užtikrinti visapusišką gyventojų gerovę. 
Pateiktame šalies konkurencingumo apibrèžime kertiniu aspektu išlieka šalies našumo didinimas, nes būtent tai sukuria materialią žmogaus gyvenimo gerovę. Tačiau atsižvelgiant $\mathfrak{i}$ tai, kad pagrindinis šalies konkurencingumo tikslas yra visapusiška žmogaus gyvenimo kokybè, gerovès, kaip apimančios neekonominius veiksnius, sąvoka minima atskirai.

\subsection{Teoriniai šalies konkurencingumo modeliai}

Atlikta šalies konkurencingumo sampratos analizė atskleidè, kad M. E. Porter, (1990, 1998) siekdamas suprasti darnų šalies ekonominį klestējimą lemiančius veiksnius, remiasi suvokimu, kad šalies konkurencingumas pirmiausia priklauso nuo joje veikiančių ịmonių našumo, atskleidžiančio žmogiškujuu, kapitalo ir natūralių išteklių panaudojimo efektyvumą. Autorius išskiria makroekonominị ir mikroekonomini konkurencingumo aspektus. Makroekonominis konkurencingumas per atitinkamos politikos, socialinès ir institucinès infrastruktūros buvimą sukuria būtiną potencialą mikroekonominiam konkurencingumui, kuris yra esminis šalies našumo didèjimui. Būtent mikroekonominio konkurencingumo, apimančio verslo aplinkos kokybę, susijusių pramonès šakų plètrą ir ịmonių strategijos, struktūros ir konkurencingijos aspektus, analizei autorius ir sukūrè „deimanto“ modelį, leidžiantị atskleisti svarbiausius šalies konkurencingumą lemiančius veiksnius (1.5 pav.).

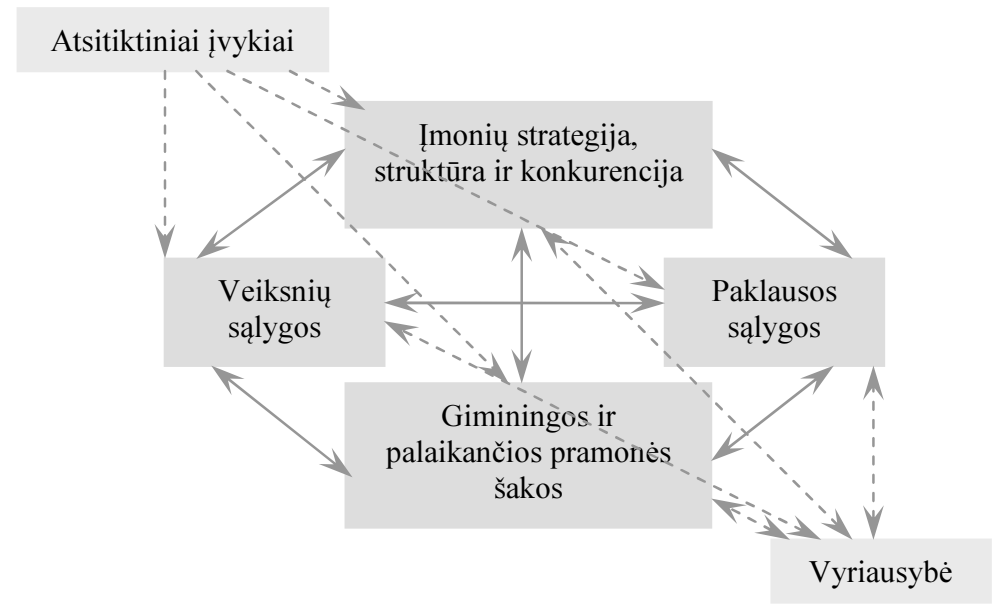

1.5 pav. „Deimanto“ modelis

Fig. 1.5. Diamond model

Šaltinis: Porter 1998 
„Deimanto“ modelis parodo, kaip kartu veikdami veiksniai, sudarydami tokias grupes kaip veiksnių sąlygos, paklausos sąlygos, įmonių strategija, struktūra ir konkurencija, giminingos ir palaikančios pramonès šakos, sukuria verslo aplinkos dinamiškumą, stimuliuoja ir intensyvina konkurenciją. Tuo tarpu netiesiogini poveikị turinti valstybès ekonominè politika, siekdama kuo didesnio įmonių našumo, yra atsakinga už minètų veiksnių grupių būklès gerinimą.

„Deimanto“ modelyje nurodytos veiksnių sąlygos apima gamybos veiksnius, svarbius pramonès ir visos šalies konkurencinio pranašumo formavimuisi: žmogiškuosius, fizinius, žinių ir kapitalo išteklius, infrastruktūrą. Šie veiksniai dar skirstomi ị esminius (bendrus) ir pažangesnius (specialiuosius). Esminiai veiksniai, kurie dar gali būti pavadinti prigimtiniais, yra tokie veiksniai kaip šalies klimatas, nekvalifikuota ar žemos kvalifikacijos darbo jejga ir pan. O pažangūs veiksniai apima tas sąlygas, kurias šalis sukuria pati, pvz. aukštos kvalifikacijos darbuotojai. Konkurencinis pranašumas, kurio pagrindas yra esminiai veiksniai yra nesudètingas ir dažnai trumpalaikis, o pažangūs veiksniai lemia aukštesnio lygio, ilgalaikị konkurencingumą.

Paklausos sąlygos - tai vidaus rinkos paklausos didèjimo tempai ir struktūra, diferenciacija pagal produktus, vartotojų reiklumas kainai ir kokybei bei jų teikiamas prioritetas šalyje pagamintiems produktams. Tradiciškai paklausos sąlygos suprantamos kaip vietos rinkos dydis, tačiau M. E. Porter (1998), daugiausia dèmesio skirdamas paklausos kokybei, pateikè toki požiūrị: specifiniai pirkèju poreikiai gali suteikti įmonèms unikalią galimybę išmokti savo gaminama produkcija ir teikiamomis paslaugomis patenkinti šiuos poreikius. $O$ jeigu vietos pirkejjų poreikiai dar įspejja ir apie kitų rinkų poreikius, vietos rinkoje veikiančios įmonès įeidamos į naujas rinkas turès ne menką konkurencinį pranašumą. Labai išprususių ir reiklių pirkejų buvimas skatina naujoves ir investicijas, o tai didina šalies konkurencinius pranašumus tarptautiniu mastu.

Giminingos ir palaikančios pramonès šakos, arba konkrečiau - klasteriai yra svarbūs konkurencingumui, nes jie yra susiję su aukštesniu įmonès našumo ir inovacijų lygiu. Klasteriai - tai pagal geografinį principą sukoncentruotų, sąveikaujančių, vykdančių bendrą veiklą ir savo specifine veikla viena kitą papildančiu pramonès šakų, tiekejju, mokslo institucijų ir kitų organizacijų sistema, kurios egzistavimas skatina inovacijas, augimą, informacijos srautą ir technologijų plètrą.

İmonių strategija, struktūra ir konkurencija nurodo sąlygas, kurioms esant yra sukurtos, organizuotos ir valdomos šalies įmonès, taip pat atskleidžia vietos konkurencijos prigimtị. Pasak M. E. Porter (1998), šalys bus sèkmingos tose pramonès šakose, kuriose taikoma adekvati konkurencinių pranašumų šaltiniams valdymo praktika. Jei įmonių strategija nebus orientuota i veiklą konkurencijos sąlygomis ir nebus galvojama apie ateities perspektyvas, tai tokios įmonės užsienio rinkose konkurencinio pranašumo neigis. 
„Deimanto“ modelyje vienas iš išorinių veiksnių - atsitiktiniai įvykiai matomas kaip galintis tiek sustiprinti tiek susilpninti šalies konkurencingumą. Šalys turinčios stiprius konkurencinius pranašumus visų „deimanto“ veiksnių atžvilgiu atsitiktinius įvykius sèkmingai galès paversti konkurenciniais pranašumais. Kitas išorinis veiksnys - vyriausybe taip pat gali turèti tiek neigiamos tiek teigiamos įtakos visiems „,deimanto“ veiksniams. Sèkminga vyriausybès ekonomikos politika yra ta, kuri sukuria šalyje aplinką, leidžiančią ịmonėms ịgyti konkurencinių pranašumų tarptautiniu mastu, o ne ta, kuri tiesiogiai įtraukia įmonę i konkurencinių pranašumų kūrimo procesą.

Suprasdamas, kad priklausomai nuo šalies plètros stadijos skiriasi ir konkurencingumą lemiančių veiksnių įtaka bendram šalies konkurencingumui, paskutiniame savo analizès etape M. E. Porter (1998) pateikè keturias nacionalinio konkurencingumo plètros stadijas, kurių pirmosios trys reiškia sẻkmingą šalies konkurencingumo didèjimą, o ketvirtoji - nuosmuki (1.4 lentelè).

1.4 lentelè. Nacionalinio konkurencingumo plètros stadijos

Table 1.4. The stages of the national competitiveness development

\begin{tabular}{|l|l|}
\hline $\begin{array}{c}\text { Plètrą skatinantys } \\
\text { veiksniai }\end{array}$ & \multicolumn{1}{c|}{ Konkurencinio pranašumo šaltiniai } \\
\hline Veiksnių sąlygos & $\begin{array}{l}\text { Baziniai gamybos veiksniai, tokie kaip gamtiniai ištekliai, geogra- } \\
\text { finè padėtis, nekvalifikuota darbo jèga ir pan. }\end{array}$ \\
\hline Investicijos & Investicijos i naujas technologijas ir jų perkèlimą iš užsienio. \\
\hline Inovacijos & $\begin{array}{l}\text { Konkurencini pranašumą lemiančių veiksnių sąveika skatinant } \\
\text { nauju technologijų kūrimą. }\end{array}$ \\
\hline Gerove & $\begin{array}{l}\text { Konkurencinis pranašumas mažeja dèl dėmesio sutelkimo ị esa- } \\
\text { mos gerovès valdymą, suletejusių investicijų, sumažejusių inova- } \\
\text { cijų ir individualios motyvacijos. }\end{array}$ \\
\hline
\end{tabular}

Šaltinis: Grant 1991

Atliekant tolimesnius M. E. Porter (1990) pasiūlyto „deimanto“ modelio empirinius tyrimus buvo atskleista, kad jis nèra tinkamas vertinant mažų šalių konkurencingumą, nes visiškai ignoruoja tarptautinès veiklos svarbą. İmonių veikiančių mažoje šalyje veikla yra itin glaudžiai susijusi su tarptautine veikla dauguma šalies konkurencingumą aiškinančių veiksnių gali būti maksimizuoti būtent tarptautinès veiklos dèka. Tik šalies viduje veikiančių įmonių galimybès igyti konkurencini pranašumą prieš kitas šalis yra labai ribotos. Siekiant panaikinti ịvardintą modelio trūkumą H. C. Moon et al. (1995) pasiūlè apibendrintą „dvigubo deimanto" modeli, kuris apima ir tarptautinès veiklos aspektą (1.6 pav.).

„Dvigubo deimanto“ modelyje šalies konkurencingumas suprantamas kaip šalyje veikiančių įmonių, kurios užsiima pridètinę vertę tam tikroje pramonèje kuriančia veikla, gebejjimas nepaisant tarptautinès konkurencijos subalansuoti 
ilgainiui ịgytą vertę. Skirtingai nuo M. E. Porter, kuris neįtraukia užsienio veiklos ir teigia, kad pati efektyviausia strategija yra kiek įmanoma daugiau veiklos sričių sukoncentruoti vienoje šalyje ir iš jos aptarnauti pasaulį, čia tvari pridètinè vertè gali būti gaunama ir iš šalies ir iš užsienio kapitalo imonių. Tvarumas gali pareikalauti geografinès konfigūracijos apimančios daugelį šalių, kur įmonès specifiniai ir vietiniai privalumai esantys keliose šalyse papildo vienas kitą (Moon et al. 1995; Moon et al. 1998; Cho ir Moon 2005; Jin ir Moon 2006).

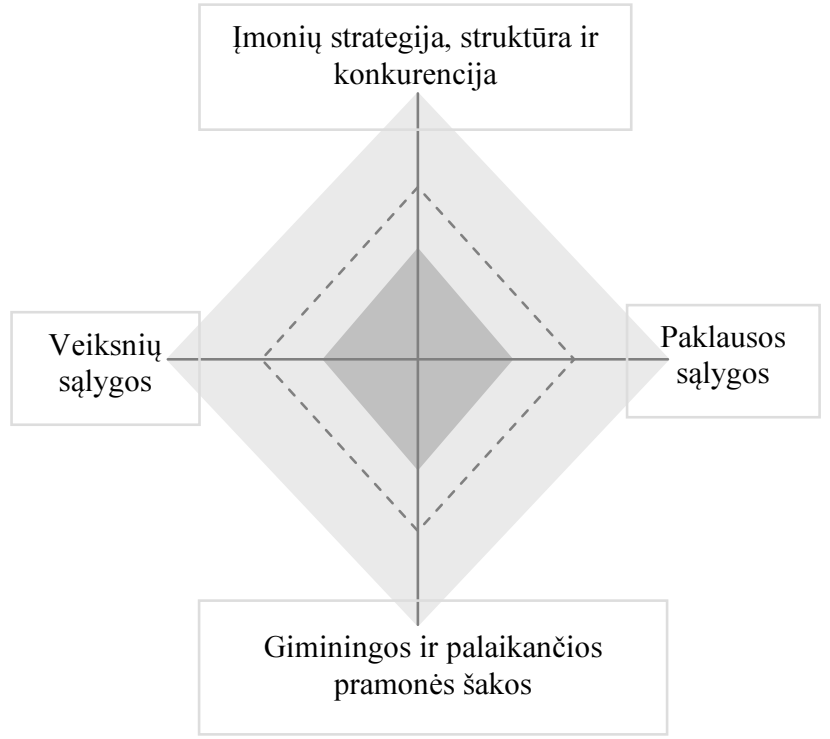

1.6 pav. „Dvigubo deimanto“ modelis

Fig. 1.6. Double diamond model Šaltinis: Moon et al. (1995)

Dar vieną „deimanto“ modelio modifikaciją - „devynių veiksnių“ modeli pasiūlè D. S. Cho (1994). Patobulinti „demanto“ modelị autorių paskatino jau anksčiau ịvardintas trūkumas - jo nepritaikomumas mažiau išsivysčiusių ar mažu šalių konkurencingumui analizuoti. Minètų šalių vidaus veiksniai yra labai riboti (Rugman 1991), todèl jos nebūtinai savo konkurencingumą kuria turèdamos visus keturis „deimanto“ modelyje išskirtus veiksnius. Todèl D. S. Cho (1994) pasiūlè į modelị itraukti ir žmogiškuosius veiksnius (1.7 pav.).

„Devynių veiksnių“ modelis aiškinant šalies konkurencingumą, be tradiciniame „deimanto“ modelyje ịvardintų fizinių veiksnių, ịtraukia ir žmogiškujų veiksnių grupes. Tokiu būdu skirtingų šalių, ypač tų, kuriose skirtingų žmonių grupių vaidmuo yra svarbus ekonominei plètrai, vertinimas tampa išsamesnis. Autorius kaip pagrindini privalumą pabrèžia dèl žmogiškujų ir fizinių veiksnių 
sąveikos atsirandanti modelio dinamiškumą. Kertinè šio modelio mintis yra ta, kad būtent žmonių, kurie geba suorganizuoti ir suvienyti fizinius veiksnius taip, kad būtų pasiektas našumas, dèka yra pasiekiamas šalies konkurencingumas.

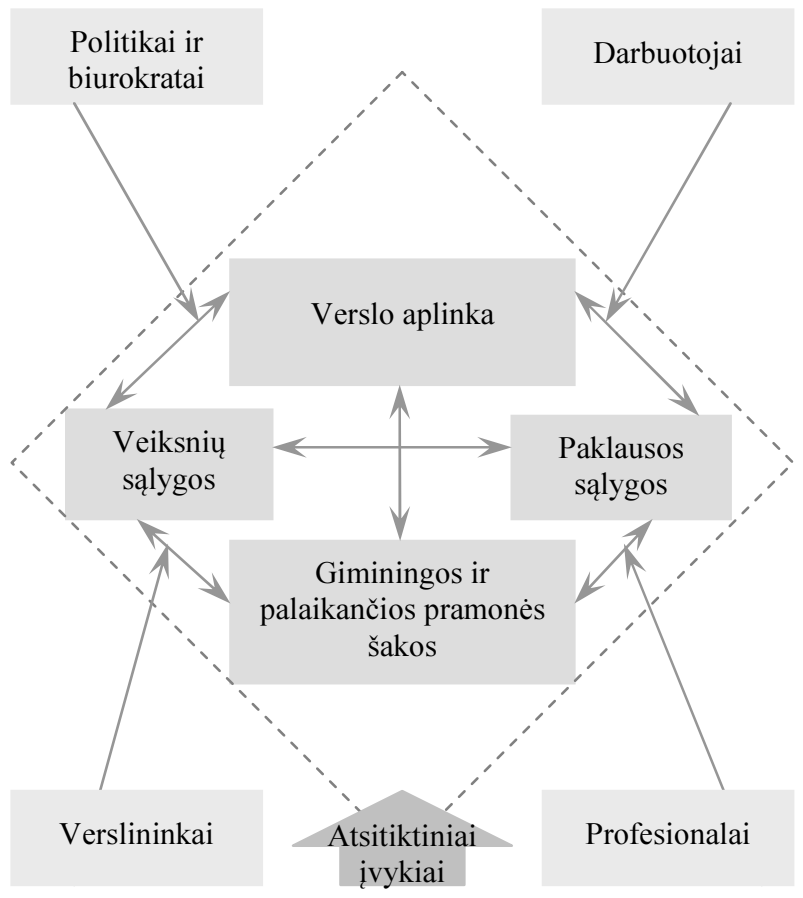

1.7 pav. „Devynių veiksnių“ modelis

Fig. 1.7. Nine-factors model Šaltinis: Cho 1994

Žmogiškuosius veiksnius sudaro darbuotojai, politikai ir biurokratai, verslininkai ir profesionalai (įskaitant mokslininkus ir vadybininkus). Šiame modelyje vyriausybẻ yra svarbus veiksnys ir turi tiesioginę įtaką šalies konkurencingumui. Vyriausybès vaidmuo priskirtas žmogiškajam veiksniui t. y. politikai ir biurokratai savo vykdoma politika daro poveiki šalies konkurencingumui. Prie konkurencingumą lemiančių išorinių veiksnių priskiriami atsitiktiniai įvykiai, kurie, pasak D. S. Cho ir H. C. Moon (2002), stiprina šalies konkurencingumą tik tuomet, kai žmogiškieji ištekliai yra pakankamai pasirengę pasinaudoti jų teikiamais pranašumais.

Apibendrinant galima pasakyti, kad M. E. Porter (1990), kuris pelnytai laikomas šalies konkurencingumo teorijos pradininku, pasiūlytas „deimanto“ mode- 
lis ir jo pagrindu, siekiant padidinti jo pritaikymo galimybes, sukurti kiti modeliai sudaro pakankamą teorinę bazę šalies konkurencingumo veiksnių nustatymui. Aptarti modeliai yra daugiau ar mažiau naudojami praktikoje, o jų pagrindu sudarytas ne vienas šalies konkurencingumą lemiančių veiksnių rinkinys, skirtas šalies konkurencingumui vertinti.

\section{6. Šalies konkurencingumą lemiantys veiksniai}

Mokslinèje literatūroje pateikiamas gana platus šalies konkurencingumą apibūdinančių veiksnių diapazonas. Tačiau didžiąą dali sudaro darbai, kuriuose analizuojami pavieniai, tam tikrą tyrimų sritị apibrežiantys ir subjektyvų supratimą apie tai, kas yra šalies konkurencingumas, atspindintys veiksniai. Minèti darbai labai pasitarnauja nustatant paskiro veiksnio įtakos šalies konkurencingumui sritis, tačiau nesuteikia galimybès susidaryti bendro vaizdo apie šalies konkurencingumo turinį. Ir nors šalies konkurencingumo veiksnių nustatymo teorinių modelių bazè tenkina poreikius, tačiau mokslinejje literatūroje pasigendama bendro, visapusiškai šalies konkurencingumą apibūdinančio veiksnių rinkinio.

Priešingai yra praktikoje, kur galima surasti ne vieną konkurencingumą šalies mastu apibūdinančių veiksnių rinkinį. Atlikta šalių patirties analizè atskleidè, kad tokie veiksnių rinkiniai naudojami šalių konkurencingumui vertinti.

Siekiant nustatyti šalies konkurencingumą lemiančius veiksnius, atitinkančius darbe suformuluotą šalies konkurencingumo apibrěžimą, atliekama praktikoje pateikiamų veiksnių rinkinių analizè. Priimant sprendimą dèl $\mathfrak{i}$ analizę įtrauktinų išskirtinai šalies konkurencingumą apibūdinančių veiksnių rinkinių svarbiausiais kriterijais laikomi: veiksnių rinkinio pagrịstumas, išsamumas ir universalumas. Atsižvelgiant ị ịvardintus kriterijus, analizuojami juos atitinkantys šalies konkurencingumo veiksnių rinkiniai, pateikiami šių organizacijų:

- Pasaulio ekonomikos forumas;

- Tarptautinis vadybos plètros institutas;

- Pramonès politikos studijų institutas.

Pasaulio ekonomikos forumas (PEF) kiekvienais metais išleidžia Pasaulio konkurencingumo ataskaitą, kurioje pateikia šalių konkurencingumo vertinimus, nurodo jų stipriąsias ir silpnąsias sritis. PEF atliekamos nacionalinio konkurencingumo analizès pagrindas - Pasaulio konkurencingumo indeksas, kurị 2004 metais sukūrè X. Sala-i-Martin. Indeksas sukurtas apjungiant anksčiau konkurencingumui vertinti taikytus Augimo konkurencingumo indeksą, kuri remiantis ekonomikos augimo teorija $2000 \mathrm{~m}$. pasiūle J. Sachs, ir Verslo konkurencingumo indeksą, kurị remiantis savo paties teorija sukūrè M. E. Porter.

Pasaulio konkurencingumo indeksas apima daugybę tam tikrus konkurencingumo aspektus matuojančių rodiklių, kurie turinio požiūriu sugrupuoti ị sudè- 
tinius veiksnius, o šie sudaro 12 konkurencingumo veiksnių grupių (1.5 lentelè). Kūrèjai indeksą detalizuoja į tris subindeksus ir, adaptavę anksčiau aptartą M. E. Porter (1990) „Plètros stadijų“ teoriją, vertinant konkurencingumą didesnius reikšmingumus suteikia tiems subindeksams, kurie yra svarbiausi šaliai esančiai tam tikroje plètros stadijoje.

1.5 lentelè. Pasaulio konkurencingumo indekso sandara

Table 1.5. Content of the Global Competitiveness Index

\begin{tabular}{|c|c|}
\hline Veiksnių grupès & Veiksniai \\
\hline Institucijos & $\begin{array}{l}\text { Viešosios institucijos (nuosavybės teisès; etika ir } \\
\text { korupcija; piktnaudžiavimas įtaka; vyriausybès } \\
\text { efektyvumas; saugumas); privačios institucijos } \\
\text { (korporacine etika; atskaitomybė) }\end{array}$ \\
\hline Infrastruktūra & $\begin{array}{l}\text { Transporto infrastruktūra; elektros energijos ir } \\
\text { telefonijos infrastruktūra }\end{array}$ \\
\hline \multicolumn{2}{|l|}{ Makroekonominė aplinka } \\
\hline Sveikata ir pradinis švietimas & Sveikata; pradinis švietimas \\
\hline $\begin{array}{l}\text { Aukštesnis švietimas ir } \\
\text { mokymai }\end{array}$ & $\begin{array}{l}\text { Švietimo apimtis; švietimo kokybė; } \\
\text { Personalo mokymai }\end{array}$ \\
\hline Produktų rinkos efektyvumas & $\begin{array}{l}\text { Konkurencija (vidaus konkurencija; užsienio } \\
\text { konkurencija); paklausos sąlygų kokybė }\end{array}$ \\
\hline Darbo rinkos efektyvumas & Lankstumas; efektyvus talentų naudojimas \\
\hline Finansų rinkos plètra & Efektyvumas; pasitikèjimas ir lojalumas \\
\hline Technologinė pažanga & $\begin{array}{l}\text { Technologijų diegimas; informacinių technologijų ir } \\
\text { telekomunikacijų naudojimas }\end{array}$ \\
\hline Rinkos dydis & Vietos rinkos dydis; užsienio rinkos dydis \\
\hline \multicolumn{2}{|l|}{ Verslo pažanga } \\
\hline MTEP inovacijos & \\
\hline
\end{tabular}

Šaltinis: The Global Competitiveness Report (2012)

Pasaulio konkurencingumo indeksą sudaro veiksniai, atskleidžiantys šalies našumo, o kartu ir jos gyventojų gyvenimo kokybės priežastis. Rinkinys sudarytas vadovaujantis M. E. Porter (1998) teiginiu, kad šalies gerovè yra sukuriama, o ne paveldima, todèl nèra ịtraukiami veiksniai, apibūdinantys šalies prigimtines gèrybes, tokias kaip natūralūs ištekliai, geografinè padètis, šalies dydis ir pan. Nors šalių prigimtinès savybès šalies gerovę veikia tiesiogiai, tačiau svarbesnis yra konkurencingumas, kuris pasiekiamas kuo našiau naudojant savo pranašumus ekonominei veiklai vykdyti. Siekiant kuo išsamiau apibūdinti tokị našumo supratimą naudojamas gausus netiesiogiai įmonių našumą veikiančių makroekonominių ir tiesioginę įtaką turinčių mikroekonominių veiksnių rinkinys. Paminètina PEF pateikiamo šalies konkurencingumą apibūdinančių veiksnių rinkinio savybė yra ta, kad ji sudaro išskirtinai ekonominiai veiksniai. Socialiniai aspektai, tokie 
kaip sveikata ir saugumas, taip pat pateikiami per ekonominị aspektą, vertinant ne jų poveikį žmogaus gerovei, o prarandamą ekonominę naudą.

Kita šalies konkurencingumo vertinimus atliekanti organizacija - Tarptautinio vadybos plètros institutas (TVPI) taip pat turi didelę patirti šioje srityje. TVPI su PEF sieja bendra praeitis - iki 1995 metu tai buvo viena organizacija konkurencingumo vertinimus atlikusi ir publikavusi nuo 1989 metų. Atsiskyrus organizacijoms, išsiskyre ir jų požiūris ị šalių konkurencingumą, pakito vertinimo objektai, metodika.

TVPI teigdama, kad gerovès kūrimas pirmiausia priklauso nuo įmonių, veikiančių nacionalinejje aplinkoje, vertina šalių gebejjimą sukurti ir palaikyti tokią aplinką, kuri suteikia galimybę įmonėms kurti didesnę vertę ir užtikrina gerovę šalies gyventojams. Nacionalinę aplinką apibūdina keturios veiksnių grupès, kurių kiekvieną sudaro po penkis konkurencingumo veiksnius (1.6 lentelè).

1.6 lentelè. Šalies konkurencingumui vertinti naudojamas veiksnių rinkinys

Table 1.6. The set of factors used for national competitiveness' assessment

\begin{tabular}{|c|c|}
\hline Veiksnių grupès & Veiksniai \\
\hline $\begin{array}{l}\text { Ekonominės } \\
\text { veiklos rezultatai }\end{array}$ & $\begin{array}{l}\text { Vidaus ekonomika (dydis; augimas; gerové; prognozė); } \\
\text { tarptautine prekyba; tarptautinès investicijos (investicijos; } \\
\text { finansai); užimtumas; kainos }\end{array}$ \\
\hline $\begin{array}{l}\text { Vyriausybės } \\
\text { efektyvumas }\end{array}$ & $\begin{array}{l}\text { Viešieji finansai; fiskalinè politika; institucinè sistema (centrinis } \\
\text { bankas; valstybės efektyvumas); verslo teisinè aplinka } \\
\text { (atvirumas; konkurencija ir reguliavimas; darbo jègos } \\
\text { reguliavimas); visuomenès struktūra }\end{array}$ \\
\hline $\begin{array}{l}\text { Verslo } \\
\text { efektyvumas }\end{array}$ & $\begin{array}{l}\text { Našumas; darbo rinka (išlaidos; santykiai; žinių prieinamumas); } \\
\text { finansai (bankų efektyvumas; vertybiniu popieriu rinkos efekty- } \\
\text { vumas; finansų valdymas); valdymo praktika; pžziūris ir vertybès }\end{array}$ \\
\hline Infrastruktūra & $\begin{array}{l}\text { Pagrindinė infrastruktūra; technologinė infrastruktūra; mokslinè } \\
\text { infrastruktūra; sveikata ir aplinka; švietimas }\end{array}$ \\
\hline
\end{tabular}

Šaltinis: The International Institute for Management Development (2013)

Nors TVPI konkurencingumą apibūdinančių veiksnių rinkinys pateikia tik keturias veiksnių grupes, tačiau ne maža dalis jas sudarančių veiksnių sutampa su prieš tai aptartame PEF veiksnių rinkinyje pateikiamais veiksniais. Kita vertus, TVPI pateikiama veiksnių sistema yra kur kas platesnè. Tai lėmé daugiau aspektų apimantis vertinamas objektas: vertinamas ne šalies rezultatas - našumas, o aplinka, kurioje veikiančios įmonès šaliai padeda pasiekti didelį našumą.

Ryšium su konkurencingumo samprata į TVPI veiksnių rinkini, kaip konkurencingumą lemiantys veiksniai, itraukti ir tokie rezultatus apibūdinantys rodikliai, kaip vidaus ekonomikos dydis (BVP), verslo našumas ir kt. Taip pat, apibūdinant pagrindinę šalies infrastruktūrą įtraukiamos ir prigimtinès šalies savybės: žemés plotas, vandens ištekliai, prièjimas prie žaliavų ir kt. Pabrèžiant šio šalies 
konkurencingumą apibūdinančių veiksnių rinkinio išskirtinumus, svarbu pažymèti ir tai, kad čia daug demesio skiriama socialiniams ir ekologiniams aspektams, kurie išskirtinai svarbūs žmogaus gerovei, - sveikatai ir jos priežiūrai, socialinei lygybei, ekologijai, atsinaujinančiajai energijai ir kt.

Pramonès politikos studijų institutas (PPSI) konkurencingumo vertinimus atlieka nuo 2001 metų. Instituto mokslininkai, jžvelgę prieš tai aptartų veiksnių rinkinių nepakankamas pritaikymo galimybes, pasiūlè naują veiksnių rinkinį, kurio pagrindas yra anksčiau aptartas „,devynių veiksnių“ modelis, sukurtas remiantis „dvigubo deimanto“ modeliu (1.7 lentelè). Pasak sudarytojų, veiksnių rinkinys yra lengvai pritaikomas bet kurioje plètros stadijoje esančioms šalims vertinti.

1.7 lentelè. Šalies konkurencingumui vertinti naudojamas veiksnių rinkinys

Table 1.7. The set of factors used for national competitiveness assessment

\begin{tabular}{|c|c|c|}
\hline \multirow{5}{*}{ 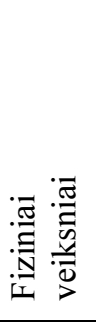 } & Veiksnių grupès & Veiksniai \\
\hline & Veiksnių sąlygos & Energijos ištekliai; kiti ištekliai \\
\hline & Paklausos sąlygos & Paklausos dydis; paklausos kokybė \\
\hline & $\begin{array}{l}\text { Susijusios pramonès } \\
\text { šakos }\end{array}$ & $\begin{array}{l}\text { Transportas; komunikacijos; finansai; švietimas; } \\
\text { mokslas ir technologijos; klasterių plètra; bendra } \\
\text { gyvenamoji aplinka }\end{array}$ \\
\hline & Verslo kontekstas & $\begin{array}{l}\text { Strategija ir struktūra; globali mąstysena; verslo } \\
\text { kultūra; užsienio investicijos }\end{array}$ \\
\hline \multirow{4}{*}{ 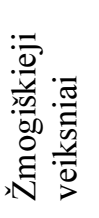 } & Darbuotojai & Darbo jègos kiekybé; darbo jègos kokybė \\
\hline & $\begin{array}{l}\text { Politikai ir } \\
\text { biurokratai }\end{array}$ & Politikai; biurokratai \\
\hline & Verslininkai & Asmeninės kompetencijos; socialinis kontekstas \\
\hline & Profesionalai & Asmeninès kompetencijos; socialinis kontekstas \\
\hline
\end{tabular}

Šaltinis: The Institute for Industrial Policy Studies (2013)

PPSI pateikiamas veiksnių rinkinys, nuo prieš tai aptartų, skiriasi išskirtiniu dèmesiu žmogiškiesiems veiksniams. Siekiant paaiškinti šalies konkurencingumą, be M. E. Porter (1998) teorijoje įvardintų svarbiausių fizinių veiksnių grupių, ịtraukiamos ir keturios žmogiškujjų veiksnių grupès. Padarant žmogiškuosius veiksnius vienodai svarbius, siekiama išsamiau apibūdinti šalis, kuriose skirtingų žmonių grupių vaidmuo yra svarbus ekonomikos plètrai. Modelis, remdamasis M. E. Porter išsakyta mintimi, kad gerovè šalyje ne paveldima, o sukuriama, rodo, kad žmonès, našiai organizuodami ir derindami fizinius veiksnius, yra pagrindinè paskata siekiant šalies konkurencingumo.

PPSI rinkinyje numatyti fiziniai konkurencingumą lemiantys veiksniai iš dalies sutampa su prieš tai aptartais veiksnių rinkiniais. Galima tik pažymèti, kad 
šiame rinkinyje išskirtinis dėmesys skiriamas klasterių plètrai, taip pat įtraukiami ir gamtiniai bei kiti šalies ištekliai.

Apibendrinant šalies konkurencingumui vertinti skirtus veiksnių rinkinius, galima pažymèti, kad, dèl skirtingo vertinamo objekto apibréžimo, jie tarpusavyje skiriasi veiksnių grupių skaičiumi, jų platumu ir turiniu, pačių veiksnių turiniu. Atsižvelgiant ị anksčiau suformuluotą šalies konkurencingumo apibrèžimą, prieinama prie išvados, kad ne vienas iš aptartų šalies konkurencingumo veiksnių rinkinių nèra tinkamas: PEF pateikiama veiksnių sistema apibūdina išskirtinai ekonominị konkurencingumą, neįtraukdama žmogaus gerovei tiesiogiai svarbių veiksnių. TVPI ir PPSI pateikiami rinkiniai, apimdami tiek ekonomiką, tiek žmonių gerovę apibūdinančius veiksnius į vertinimą taip pat įtraukia ir prigimtines šalies gèrybes.

Kita vertus, dèl savo išsamumo, universalumo ir pakankamo teorinio pagrịstumo (nors kai kurių modelių atžvilgiu yra išsakoma kritika dèl nepakankamo ju teorinio pagrịstumo (Cho ir Moon 2005), tačiau gilesnè metodikų kūrimo analizė leidžia paneigti tokius kategoriškus teiginius: šiandien pateikiamos metodikos yra daugybès metų ieškojimų, tobulinimų, tyrinèjimų ir bendradarbiavimo tarp ịvairių mokslininkų rezultatas) aptartos metodikos gali būti pagrindu sudarant priimtą šalies konkurencingumo apibrèžimą atitinkantị veiksnių rinkinị. Siekiant nustatyti šalies konkurencingumo veiksnius, aptartų rinkinių veiksniai sugrupuojami turinio požiūriu (1.8 lentelè).

Toliau atliekant mokslinès literatūros analizę ir remiantis prieš tai aptartais veiksnių rinkiniais, pagrindžiama kiekvieno veiksnio svarba šalies konkurencingumui ir, nustatant svarbiausius aspektus, atskleidžiamas jų turinys. Analizès metu taip pat eliminuojami tie veiksniai ar jų aspektai, kurie prieštarauja priimtam šalies konkurencingumo apibrèžimui.

1.8 lentelè. Šalies konkurencingumui vertinti naudojamų veiksnių grupavimas turinio požiūriu

Table 1.8. Grouping of factors used for national competitiveness' assessment in terms of content

\begin{tabular}{|l|l|l|l|}
\hline Veiksniai & \multicolumn{1}{|c|}{ PEF } & \multicolumn{1}{c|}{ TVPI } & \multicolumn{1}{c|}{ PPSI } \\
\hline $\begin{array}{l}\text { Institucinè } \\
\text { aplinka }\end{array}$ & $\begin{array}{l}\text { Viešosios } \\
\text { institucijos }\end{array}$ & $\begin{array}{l}\text { Institucinè sistema; } \\
\text { visuomenès struktūra }\end{array}$ & Politikai; biurokratai \\
\hline $\begin{array}{l}\text { Makroekono- } \\
\text { minè situacija }\end{array}$ & $\begin{array}{l}\text { Makroekonominé } \\
\text { aplinka }\end{array}$ & $\begin{array}{l}\text { Viešieji finansai; } \\
\text { fiskalinè politika; } \\
\text { institucinè sistema; } \\
\text { vidaus ekonomika }\end{array}$ & Finansai \\
\hline $\begin{array}{l}\text { Inžinerinè } \\
\text { infrastruktūra }\end{array}$ & $\begin{array}{l}\text { Transporto infra- } \\
\text { struktūra; elektros } \\
\text { energijos ir telefoni- } \\
\text { jos infrastruktūra }\end{array}$ & $\begin{array}{l}\text { Pagrindinè } \\
\text { infrastruktūra }\end{array}$ & Transportas \\
\hline
\end{tabular}


1.8 lentelès pabaiga

\begin{tabular}{|c|c|c|c|}
\hline Veiksniai & PEF & TVPI & PPSI \\
\hline $\begin{array}{l}\text { Technologinè } \\
\text { infrastruktūra }\end{array}$ & $\begin{array}{l}\text { Elektros energijos ir } \\
\text { telefonijos infra- } \\
\text { struktūra; ITT nau- } \\
\text { dojimas; techno- } \\
\text { logijų diegimas }\end{array}$ & $\begin{array}{l}\text { Technologinè } \\
\text { infrastruktūra }\end{array}$ & $\begin{array}{l}\text { Komunikacijos; } \\
\text { mokslas ir } \\
\text { technologijos }\end{array}$ \\
\hline $\begin{array}{l}\text { Mokslinè } \\
\text { infrastruktūra }\end{array}$ & MTEP inovacijos & $\begin{array}{l}\text { Mokslinè } \\
\text { infrastruktūra }\end{array}$ & $\begin{array}{l}\text { Mokslas ir } \\
\text { technologijos }\end{array}$ \\
\hline Švietimas & $\begin{array}{l}\text { Pradinis švietimas; } \\
\text { (aukštesnio) } \\
\text { Švietimo apimtis ir } \\
\text { kokybė; personalo } \\
\text { mokymai }\end{array}$ & $\begin{array}{l}\text { Švietimas; } \\
\text { darbo rinka }\end{array}$ & Švietimas \\
\hline $\begin{array}{l}\text { Socialinė } \\
\text { aplinka }\end{array}$ & Sveikata & $\begin{array}{l}\text { Sveikata ir aplinka; } \\
\text { visuomenès } \\
\text { struktūra }\end{array}$ & $\begin{array}{l}\text { Bendra gyvenamoji } \\
\text { aplinka }\end{array}$ \\
\hline Produktų rinka & $\begin{array}{l}\text { Konkurencija; } \\
\text { paklausos sąlygu } \\
\text { kokybė; vietos } \\
\text { rinkos dydis; užsie- } \\
\text { nio rinkos dydis }\end{array}$ & $\begin{array}{l}\text { Verslo teisinė ap- } \\
\text { linka; vidaus eko- } \\
\text { nomika; pagrindinė } \\
\text { infrastruktūra; } \\
\text { tarptautinè prekyba }\end{array}$ & $\begin{array}{l}\text { Paklausos kokybė; } \\
\text { paklausos dydis }\end{array}$ \\
\hline Darbo rinka & $\begin{array}{l}\text { (Darbo rinkos) } \\
\text { lankstumas; } \\
\text { efektyvus talentų } \\
\text { naudojimas }\end{array}$ & $\begin{array}{l}\text { Užimtumas; verslo } \\
\text { teisinè aplinka; } \\
\text { darbo rinka }\end{array}$ & $\begin{array}{l}\text { Darbo jègos kiekybė ir } \\
\text { kokybė; (verslininkų ir } \\
\text { profesionalu) asmeni- } \\
\text { nės kompetencijos ir } \\
\text { socialinis kontekstas; }\end{array}$ \\
\hline Finansų rinka & $\begin{array}{l}\text { (Finansų rinkų) } \\
\text { efektyvumas, } \\
\text { patikimumas ir } \\
\text { konfidencialumas }\end{array}$ & Finansai & Finansai \\
\hline Verslas & $\begin{array}{l}\text { Verslo pažanga; } \\
\text { Privačios instituci- } \\
\text { jos; paklausos } \\
\text { sąlygų kokybė }\end{array}$ & $\begin{array}{l}\text { Valdymo praktika; } \\
\text { (verslo) požiūris ir } \\
\text { vertybės, našumas } \\
\text { ir efektyvumas; } \\
\text { užsienio } \\
\text { investicijos }\end{array}$ & $\begin{array}{l}\text { Klasteriu plètra; verslo } \\
\text { kultūra; verslo strategi- } \\
\text { ja ir struktūra; paklau- } \\
\text { sos kokybė; globali } \\
\text { mąstysena; užsienio } \\
\text { investicijos }\end{array}$ \\
\hline Ištekliai & & $\begin{array}{l}\text { Pagrindiné } \\
\text { infrastruktūra }\end{array}$ & $\begin{array}{l}\text { Energijos ištekliai; } \\
\text { kiti ištekliai }\end{array}$ \\
\hline
\end{tabular}

Pastaba: Pasviruoju šriftu žymimi pasikartojantys veiksniai.

Šaltinis: sudaryta autorès

Instituciné aplinka. Šiandien jau nekyla abejonių dèl institucinès aplinkos svarbos šalies ekonomikai, jos žmoniu gerovei, o kartu ir šalies konkurencingumui (Weede ir Kampf 2002; Gwartney et al. 2004; Acemoglu ir Johnson 2005; 
Butkiewicz ir Yanikkaya 2006; Law ir Bany-Ariffin 2008; Eicher ir Leukert 2009; Šeputienè 2009). Šalyse, kuriose tinkamai funkcionuoja nuosavybės teises užtikrinančios institucijos, ne tik efektyviau panaudojami ištekliai, bet ir sparčiau vyksta technologine pažanga, veikianti ilgalaiki ekonomikos augimą ir skurdo mažejimą (Knack 2002). Kitos pagrindinès funkcijos, kurias atlikdamos institucijos teigiamai veikia šalies ekonomiką yra tokios (Rodrik et al. 2004; Gagliardi 2008): sandorio sąnaudų ir neapibrèžtumo mažinimas, ekonomikos agentų veiksmų koordinacija, bendradarbiavimo skatinimas, ìstatymų viršenybės užtikrinimas, kova su korupcija, tinkamas produktų ir gamybos veiksnių reguliavimas, makroekonominio stabilumo užtikrinimas ir socialinès vienybès skatinimas.

Itin svarbia dalimi institucinès aplinkos poveikis šalies ekonomikos konkurencingumui pasireiškia per šalyje veikiančio verslo patiriamas sandorių ir gamybos išlaidas. Sandorių išlaidos bus didesnès (neigiamas poveikis), jei nebus galima pasitikèti nuosavybès teisių apsauga, i̦statymų viršenybe. Tokiose situacijose ịmonių veiklos mastai dažniausiai yra nedideli, galbūt net nelegalūs, o veiklą dar palengvina kyšininkavimas ir korupcija. Jei nèra užtikrinamas sutarčių vykdymas, didèja gamybos sąnaudos, i̇monèms sudètingiau igyvendinti ilgalaikes strategijas (Aron 2000). J. Aixala ir G. Fabro (2008) pabrěžia, kad tvirta institucinè aplinka yra itin svarbi investicijoms: investuotojai nebus linkę rizikuoti savo kapitalu, jei nebus užtikrinama jų nuosavybès teisių apsauga ir kils grèsmè, kad gali prarasti uždirbtas pajamas. Šalyje klestinčią korupciją investuotojai gali vertinti kaip tam tikrą mokesčių rūšį, kuri didina sandorių sąnaudas ir neapibrèžtumą, mažina paskatas investuoti.

Makroekonomine situacija. Markoekonominè situacija labai glaudžiai siejasi su prieš tai aptarta institucine aplinka, nes būtent institucijos, atlikdamos savo funkcijas, atsakingos už makroekonomikos stabilumą, kuris yra itin svarbus šalies verslui, o kartu ir visam šalies konkurencingumui. Tiesiogiai šis veiksnys neprisideda prie šalies našumo didejjimo, tačiau žinoma, kad bet koks makroekonomikos sutrikimas itin kenkia ekonomikai. Kad stabili makroekonomika, kurią apibūdina žema ir stabili infliacija, tinkama (žema) ilgalaikių palūkanų norma, valiutos stabilumas, maži valstybès skola ir biudžeto deficitas bei subalansuota fiskalinè politika, yra viena svarbiausių ekonomikos gerovès sąlygų, patvirtina ir nemažas mokslinių darbų potencialas šioje srityje (De Gregorio 1993; Bruno ir Easterly 1998; Lawson ir Wang 2005; Falcetti et al. 2006; Efendic et al. 2008; Iradian 2009; Martinez ir Sanchez-Robles 2012).

Makroekonominio nestabilumo, pasireiškiančio aukštu infliacijos lygiu, žalą ekonomikai aiškinančios teorijos teigia, kad: infliacija mažina investicijų grąžos normą; iškraipydama kainas ir darydama įtaką efektyviam išteklių paskirstymui, kenkia gamybos veiksnių našumui; signalizuoja apie fiskalinès ir monetarinès politikos kontrolès stoką; verčia įmones skirti lèšas nenašioms sritims (pvz. draudimui); didina palūkanų normos rizikos priemoką ir trukdo geram finansų rinkų 
funkcionavimui. Pasireikšdamas bet kuriuo požymiu makroekonominis nestabilumas lemia privačių investicijų išstūmimą (crowing out effect).

Inžinerine infrastruktūra. Mokslininkai (Phang 2003; Pradhan ir Bagchi 2013) sutinka, kad infrastruktūros tinklų kokybe ir plètra daro didelę įtaką ekonomikos augimui, šalies gyventojų gerovei ir užtikrina šalies konkurencingumą. Literatūroje minimi du aspektai siejantys transporto infrastruktūros gerinimą su šalies našumu - tai sumažintos transportavimo išlaidos ir pagerintas susisiekimas (Boopen 2006). Efektyvi transporto infrastruktūra - keliai, geležinkeliai, uostai ir oro transportas - padeda ịmonėms saugiai ir laiku pateikti savo produktus į rinką ir palengvina darbuotoju judejjimą i jiems tinkamiausia darbo vietas. Šie aspektai padeda ne tik tiesiogiai lemdami šalies našumą, bet ir netiesiogiai tokiose svarbiose srityse, kaip gamybos reorganizavimas ir racionalizavimas, geresnis privačių investicijų našumas ir aukštesnis lygis, platesnès rinkos, padidèjusi specializacija ir masto ekonomija, darbo rinkos tiekimas, darbo išlaidos ir našumas.

Ekonomika taip pat labai priklauso nuo elektros energijos tiekejjų, kurių teikiamų paslaugu kokybė itin svarbi šalyje veikiančioms įmonėms. Galima būtų išskirti tiesiogini ir netiesiogini elektros energijos poveikį. Tiesioginis poveikis, pasak A. Isaksson (2010), atsiskleidžia per gamybą, kuriai tai yra vienas svarbiausių gamybos išteklių: be elektros energijos ir kokybiško jos tiekimo nebūtų įmanoma jokia mechanizuota gamyba; esant netolygiam elektros tiekimui trikdomas gamybos procesas; itampų svyravimai neigiamai veikia mašinų patvarumą. A. Estache (2006) pažymi, kad kuo daugiau šalyje sektorių, glaudžiai susijusių su elektros energija, tuo ji tampa svarbesnè bendrai gamybai ir plètrai. Netiesiogini energetikos infrastruktūros poveiki junta švietimo ir sveikatos paslaugomis besinaudojantys gyventojai. Ligoninès ir kitos sveikatos bei švietimo įstaigos yra labai priklausomos nuo elektros energijos, kuri suteikia galimybes naudotis svarbia medicinine ịranga ir mokymosi priemonèmis (Agenor 2009).

Technologine infrastruktūra. Moksliniai tyrimai atskleidžia technologiju svarbą įmonių klestejjimui ir bendrai šalies ekonominei plètrai (Gust ir Marquez 2004; O‘Mahony ir Vecchi 2005; Koutroumpis 2009; Czernich et al. 2011; Kretschmer 2012). Tai pasireiškia per šalies įmonèms suteiktas galimybes prieiti prie pažangių produktų ir projektų, laisvai jais naudotis. Informacinès technologijos ir komunikacijos (ITT) dèl savo svarbaus poveikio daugumos kitų sektorių veiklai ir našumui šiandien vis dažniau vadinamos ,bendrojo pobūdžio technologijomis“ (Jovanovic ir Rousseau 2005). ITT, suteikdamos imonèms galimybes taikyti veiksmingesnius bendradarbiavimo ir informacijos apdorojimo procesus, palengvina bendravimą ir naujų žinių kūrimo procesus. Spartesnis informacijos apdorojimas atveria galimybes naujiems bendravimo su tiekejjais būdams, efektyvesniam paskirstymo sistemų organizavimui. Procesai gali būti pertvarkomi ir reorganizuojami numatant geresni ịrangos naudojimą, atsargų ar erdvès reikalavimų sumažinimą, o tai leidžia sumažinti kapitalo poreikius. Efektyvesnis ben- 
dravimas taip pat sumažina koordinavimo išlaidas ir priežiūros institucijų skaičių. Greitas ir laisvas informacijos perdavimas, užtikrindamas, kad sprendimai, priimami remiantis visa įmanoma informacija, sumažina darbo sąnaudas, dèl ko sukuriamos papildomos galimybès diegti naujoves, didina visos šalies ekonomikos efektyvumą (Gilchrist et al. 2001; Atrostic et al. 2002, Arvanitis ir Loukis 2009; Brynjolfsson ir Saunders 2010).

Moksline infrastruktūra. Gebejjimas kurti inovacijas ir sèkmingai jas pateikti rinkai yra esminis šalies konkurencingumo veiksnys. Šiandien dar stebimas ir supratimas, kad inovacinè veikla yra ne tik esminis tolesnio ekonomikos progreso ir gerovès veiksnys, tačiau ir potencialus veiksnys pasitinkant pasaulinius iššūkius tokiose srityse, kaip aplinka ir sveikata.

Ilgalaikis ekonominis augimas tiek išsivysčiusiose, tiek besivystančiose šalyse palaikomas tik nuolat kuriant ir realizuojant naujoves. Mažiau išsivysčiusios šalys savo našumą dar gali didinti adaptuodamos esamas technologijas, tačiau išsivysčiusioms šalims to jau nepakanka. Imonès išsivysčiusiose šalyse, siekdamos palaikyti konkurencingumą, turi kurti ir plètoti pažangiausius produktus ir procesus (Pham 2010). Moksliniai tyrimai (Steinberg ir Arndt 2001; Mairesse ir Mohnen 2005) įrodo, kad inovacijų kūrimui itin svarbi gerai išplètota, inovatyviai veiklai palanki infrastruktūra - tai gausiai vykdomi moksliniai tyrimai ir eksperimentine plètra, pakankamas mokslininkų ir tyrejjų, aukštos kvalifikacijos mokslinių tyrimų institucijų potencialas, universitetų ir pramonès bendradarbiavimas bei intelektinès nuosavybès apsauga.

Švietimas. Moksliniais tyrimais irodyta, kad švietimas (Romer 1990; Mankiw et al. 1992; Aghion et al. 1998; Sahlberg 2006; Knight et al. 2010) ir tuo labiau jo kokybè (Woessmann 2003; Bosworth ir Collins 2003; Coulombe ir Tremblay 2006; Jamison et al. 2007, Hanushek ir Wobmann 2010) turi teigiamą poveikị šalies gyventojų gerovei ir ekonomikos plètrai. Išskiriamos mažiausiai trys švietimo teigiamo poveikio ekonomikai sritys: pirma, švietimas didina žmogiškajji kapitalą ir taip prisideda prie darbo jègos našumo augimo; antra, švietimas padidina ekonomikos gebejimą kurti inovacijas; trečia, švietimas palengvina žinių sklaidą ir perdavimą, kas svarbu norint suprasti ir apdoroti naują informaciją bei sèkmingai diegti naujausias technologijas. Be akivaizdaus poveikio pajamoms ir inovacijoms, švietimas, tiesiogiai prisidèdamas prie žmogaus materialinès gerovès kūrimo, veikia jo sveikatą ir laimę.

Mokslineje literatūroje (Petrakis ir Stamatakis 2002; Papageorgiou 2003) pateikiami įrodymai, kad visi išsilavinimo lygiai reikšmingai prisideda prie ekonomikos pletros, tačiau tas reikšmingumas skiriasi priklausomai nuo šalies išsivystymo lygio. Pagrindinis ugdymas gerokai prisidedamas prie galutinès produkcijos gamybos, yra itin svarbus mažiau išsivysčiusioms šalims, o aukštesnis išsilavinimas, turintis daug įtakos technologijų kūrimo ir taikymo procesams, - išsivysčiusioms. Pagrindinis išsilavinimas didina kiekvieno individualaus darbuotojo 
efektyvumą, tačiau tik tokị išsilavinimą turinčią darbo jègą žymiai sudètingiau adaptuoti prie pažangesniu produkcijos procesu ir technikos. Žmonès su aukštesniu išsilavinimu ne tik turi didesni žinių potencialą ir geriau geba naudotis technologijomis bet ir yra labiau linkę kurti naujas priemones ir lavinti igūdžius patys. Ju žinios taip pat gali patobulinti žemesnį išsilavinimą turinčių bendradarbių igūdžius. Aukštesnio išsilavinimo suteiktas didesnis pasitikejjimas ir knowhow skatina verslumą, kas daro teigiamą poveikị darbo vietų kūrimui. Akivaizdu, kad dabartinè globali ekonomika kelia reikalavimus šalims turèti gerai išsimokslinusius darbuotojus, gebančius greitai prisitaikyti prie besikeičiančios aplinkos, todèl skatinamas ir nuolatinis darbo rinkoje jau esančių darbuotojų tobulinimasis.

Socialine aplinka. Sveikata tiesioginis žmogaus gerovès šaltinis ir, kaip atskleidžia tyrimai (Bhargava et al. 2001; Bloom et al. 2004), svarbi augančių nacionalinių pajamų lygio priemonè. Prasta sveikata ir ligotumas užkrauna ekonominę naštą tiek pačiam žmogui, tiek verslui ir valstybei. Esant nesveikai populiacijai patiriami dideli nuostoliai, pasireiškiantys per padidejusias draudimo išmokas, išaugusias verslo ir viešąsias išlaidas medicininiai pagalbai bei priežiūrai.

Sveikatos poveikis šalies ekonomikos gerovei pasireiškia per keletą mechanizmu (Bloom et al. 2004). Pirmas, sveikatos vaidmuo darbo jègos našumui: sveiki darbuotojai praranda mažiau darbo laiko dèl blogos sveikatos ir yra kur kas našesni, kai dirba. Antras, sveikatos poveikis švietimui: sveikata vaikysteje gali turèti tiesiogini poveiki pažinimo vystymuisi, gebejjimui mokytis ir reguliariam mokyklos lankymui. Trečias, sveikatos poveikis santaupoms: ilgesnè būsimojo gyvenimo trukmé gali padidinti paskatą taupyti pensijai, taip pat, nepatiriant didelių išlaidų sveikatos priežiūrai, išsaugoma materialinè šeimos gerovè. Ketvirtas, sveikatos poveikis populiacijos dydžiui ir amžiaus struktūrai.

Šalies konkurencingumą suvokiant kaip šalies gebejjimą užtikrinti savo gyventojams ne tik materialinę bet ir socialinę gerovę svarbūs tampa ir tokie gyvenimo gerovei tiesiogiai didelę įtaką turintys aspektai kaip socialinè lygybė, ekologija, atsinaujinančioji energetika. Siekiant sukurti materialini gerbusi intensyviai vykdoma ekonominè veikla, viena vertus, neigiamai veikia aplinką, o, kita vertus, augant ekonomikoms didejja ir dèmesys, skiriamas ekologijos, atsinaujinančiosios energetikos problemoms spręsti (Pautrel 2009).

Produktu rinka. Šalių konkurencingumą vertinančios organizacijos kaip paskirą konkurencingumui svarbų veiksni vertina rinkos dydi, teigdamos, kad tai lemia našumą, nes didelès rinkos leidžia ịmonèms išnaudoti masto ekonomiją, lengviau pritraukti investicijas. Atsižvelgiant i priimtą šalies konkurencingumo sampratą, rinkos dydis, išreiškiamas BVP dydžiu, traktuotinas kaip konkurencingumo rezultatas, o ne ji lemiantis veiksnys. Šalių konkurencingumui už rinkos dydi kur kas svarbesnis yra jos efektyvumas.

Šalys su efektyvia produktų rinka, pateikdamos pasiūlos ir paklausos nulemtą produkcijos ir paslaugų kompleksą ir užtikrinančios, kad ta produkcija ekono- 
mikoje bus prekiaujama efektyviausiu būdu, skatina konkurencingumo augimą. Rinkos efektyvumas, o kartu ir verslo našumas, dažnai siejamas su sveika tiek namų tiek užsienio rinkų konkurencija (Griffith 2001). Geriausia galima aplinka produktų apsikeitimui reikalauja minimalių trukdžių, pasireiškiančių per valdžios îsikišimus, pvz., iškreiptų ar apsunkintų mokesčių bei suvaržančių ir diskriminuojančių taisyklių užsienio nuosavybei, tiesioginėms užsienio investicijoms (The Global Competitiveness Report 2012). Kita vertus, I. Formosa (2008) pažymi, kad vyriausybè, sukurdama reikalingas institucijas, atlikdama piktnaudžiavimo dominuojančia padètimi kontrolę, slaptų susitarimų tarp įmonių prevenciją ir pašalindama patekimo i rinką kliūtis vis tik atlieka labai svarbų vaidmeni skatinant rinkos efektyvumą.

Darbo rinka. Darbo rinkos svarba šalies ekonomikai ir jos našumo augimui yra neginčijama, todèl siekiant nacionalinio konkurencingumo jos efektyvumas ir lankstumas yra esminiai užtikrinant, kad žmogiškasis kapitalas naudojamas pačiu našiausiu būdu (Melody 2002; Burgess et al. 2003). Darbo rinka turi būti lanksti, kad būtų sudarytos sąlygos darbuotojus pakeisti greitai, patiriant kuo mažiau sąnaudų ir, atsižvelgiant $i$ atlyginimų svyravimus, be didelio socialinio nuostolio. Pasak C. Pissarides (1997), darbo rinka laikoma lanksčia, kai ji geba prisitaikyti prie bet kokių sukrètimų ir nuolat besikeičiančios ekonominès aplinkos. Darbo rinkai trūkstant lankstumo, ekonomikos prisitaikymas bus lètesnis, o nedarbo lygis - aukštesnis (Forteza et al. 2002). Efektyvi darbo rinka turi užtikrinti aiškius santykius tarp darbuotojų iniciatyvų ir jų pastangų, taip pat leisti geriausiai panaudoti turimus talentus, užtikrinti lygybę tarp vyrų ir moterų verslo aplinkoje.

Finansu rinka. Šalis sukretusi globali finansų krize išryškino ypatingą finansų rinkų svarbą sèkmingam nacionalinių ekonomikų funkcionavimui. Empiriniai tyrimai patvirtina, kad ekonomika yra labai priklausoma nuo bankų sistemos ir akcijų rinkos efektyvumo (Gregorio et al. 1995; Levine et al. 2000; Calderon ir Liu 2003; Choong et al. 2005; Adamopoulos 2010; Wong ir Zhou 2011).

Šalies našumui, kuris užtikrina nacionalinị konkurencingumą, labai svarbios verslo investicijos. Būtent efektyvi finansų rinka, dèl tokių šaltinių, kaip bankų sektoriaus teikiamos paskolos, gerai reguliuojami vertybinių popierių mainai, rizikos kapitalas ir kiti finansiniai produktai, kapitalą padaro prieinamą privataus sektoriaus investicijoms, kurios savo ruožtu nukreipiamos i fizinius ir žmogišskuosius išteklius. Finansų rinkų efektyvumas pasireiškia gebejjimu reaguoti i paklausą ir aukštos kokybės produktų bei paslaugų mažiausiomis kainomis teikimą. Efektyviam funkcijų atlikimui labai svarbus bankų sektoriaus patikimumas ir skaidrumas (The Global Competitiveness Report 2012).

Nemažai mokslininkų dėmesio sulaukia akcijų rinkos ir jų poveikis šalies bankiniam sektoriui bei ekonomikos skatinimui (Greenwood ir Jovanovic 1990; Pagano 1993; Bencivenga et al. 1996; Becsi ir Wang 1997; Levine ir Zervos 1998; Khan 2000). Gerai funkcionuojanti akcijų rinka, skirtingai negu bankai, 
finansuojantys tik gerai nusistovejusius, saugius objektus, suteikia ilgalaikị finansavimą ir labai rizikingiems, tačiau inovatyviems ir pelningiems projektams ir užtikrina tinkamą likvidumą, dèl ko ji tampa lengviau prieinama investuotojams, o įmonėms suteikiama prieiga prie ilgalaikių lèšų.

Nors pagrindinis efektyvaus ilgalaikių finansinių priemonių mechanizmo poveikis šalies konkurencingumui pasireiškia per verslo našumo augimą, tačiau derètu paminèti ir tai, kad platus gerovès kūrimo galimybių diapazonas sudaromas ir vyriausybei bei privatiems asmenims.

Verslas. Mokslinès literatūros analizė atskleidžia, kad būtent šalyje veikiančių įmonių efektyviai vykdoma ekonominè veikla yra šalies našumo ir gyventojų gerovès pagrindas. TVPI kaip vieną iš konkurencingumą lemiančių veiksnių pateikia verslo efektyvumą, tačiau atsižvelgiant i priimtą sampratą, jis traktuotinas kaip konkurencingumo rezultatas. Šalyje veikiančio verslo efektyvumas ir našumas, atskleidžiantys šalies konkurencingumo lygi, priklauso ne tik nuo prieš tai aptartų veiksnių, bet ir nuo paties verslo pažangos, apimančio stiprią i̇monių atskaitomybès, valdymo ir kultūros praktiką, taikomų strategijų ir operacijų modernumą ir klasterių plètrą.

Siekiant išlaikyti investuotojus bei vartotoju pasitikejimą, itin svarbus vykdomos veiklos skaidrumas, užkertantis kelią apgavystèms ir neefektyviam valdymui. Skaidrumą versle užtikrina standartų, audito ir apskaitos, suteikiančių priejjimą prie informacijos laiku, naudojimas. Tik toks verslas, kuris bus vykdomas sąžiningai ir bendradarbiaujant tarpusavyje, su valdžia ir visuomene laikysis tvirtų moralinių normų teigiamai veiks visos šalies ekonomiką.

Tiesiogiai efektyvų įmonių valdymą lemia jos vadovybè, todèl svarbūs tampa sąmoningumo ir atsiribojimo nuo asmeniškumų paplitimas, užtikrinantis, kad vadovaujamos pozicijos skiriamos profesionalams ir jų gebejjimas paskirstyti valdymo funkcijas. Bendrą šalies verslo kokybę leidžia užtikrinti ir įmonių operacijų ir strategijų keitimas laiku į modernius verslo procesus.

Dar vienas aspektas dažnai minimas apibūdinant verslo vaidmeni šalies konkurencingumui yra klasteriai. Pasak V. Snieškos et al. (2002), klasteriai gali būti traktuojami kaip vertinga priemonė siekiant efektyvių ekonomikos pokyčių. Kai imonès ir tiekejjai, atstovaujantys tam tikrai sričiai, yra susieti i geografiškai artimas grupes, didejja jų efektyvumas, atsiranda daugiau galimybių inovacijų plètrai bei mažèja barjerai ateiti naujoms įmonèms. Tai ypač svarbu šalims, pasiekusioms aukštesni plètros lygị, kai bazinių našumo šaltinių jau nebepakanka (Porter 2003).

Ištekliai. Pasaulio patirtis rodo, kad šalių disponuojami gausūs ištekliai dar negarantuoja joms didelio konkurencingumo. Tokios šalys, kaip Rusija ir Brazilija, užimančios dideles teritorijas, turinčios dideles populiacijas bei turtingos gamtinių išteklių, yra mažiau konkurencingos, lyginant su Šveicarija ar Japonija, kurios neturi gausių gamtinių išteklių. Mokslininkai netgi ịrodo neigiamą gamtinių 
ištekliu gausos ịtaką gerovès lygiui (Sachs ir Warner 2001; Papyrakis ir Gerlagh 2004). Remiantis M. E. Porter (1998) išsakytu požiūriu, kad šalies gerovè sukuriama vykdant ekonominę veiklą, galima teigti, kad svarbiausiu dalyku siekiant šalies konkurencingumo yra jos gebejjimas kuo našiau naudoti šalies turimas prigimtines gèrybes. Atsižvelgiant ị tai ištekliai nèra traktuojami kaip vienas konkurencingumą lemiančių veiksnių.

Apibendrinant atliktą literatūros analizę šalies konkurencingumą lemiantys veiksniai ir jų turinys pateikiami 1.9 lenteleje.

1.9 lentelè. Šalies konkurencingumą lemiantys veiksniai

Tabale 1.9. Factors that influence national competitiveness

\begin{tabular}{|c|c|}
\hline Veiksniai & Turinys \\
\hline $\begin{array}{l}\text { Institucinè } \\
\text { aplinka }\end{array}$ & $\begin{array}{l}\text { Teisiniai ir vyriausybės veiklos aspektai: teisinès ir reguliavimo } \\
\text { sistemos efektyvumas ir kokybè, vyriausybės vykdomos veiklos } \\
\text { skaidrumas ir veiksmingumas. }\end{array}$ \\
\hline $\begin{array}{l}\text { Makroekonomi- } \\
\text { nè situacija }\end{array}$ & $\begin{array}{l}\text { Makroekonominị stabilumą nusakantys aspektai: fiskalinè ir } \\
\text { monetarinè politika, viešieji finansai. }\end{array}$ \\
\hline $\begin{array}{l}\text { Inžinerinè } \\
\text { infrastruktūra }\end{array}$ & $\begin{array}{l}\text { Transporto (keliu, geležinkelių, uostu ir kt.) ir energijos perdavimo } \\
\text { infrastruktūros efektyvumas ir kokybè. }\end{array}$ \\
\hline $\begin{array}{l}\text { Technologinè } \\
\text { infrastruktūra }\end{array}$ & $\begin{array}{l}\text { Informacinių technologijų ir telekomunikacijų prieinamumas ir } \\
\text { naudojimas; naujausių technologiju prieinamumas, diegimas }\end{array}$ \\
\hline $\begin{array}{l}\text { Mokslinè } \\
\text { infrastruktūra }\end{array}$ & $\begin{array}{l}\text { Inovacijų kūrimo pajègumai, mokslo institucijų kokybè, mokslo ir } \\
\text { verslo bendradarbiavimas, žmogiškujų mokslo išteklių } \\
\text { prieinamumas, našumas. }\end{array}$ \\
\hline Švietimas & $\begin{array}{l}\text { Pradinis ir aukštesnis švietimas, aukštasis mokslas, darbuotojų } \\
\text { mokymai. }\end{array}$ \\
\hline Socialinė aplinka & $\begin{array}{l}\text { Sveikata ir sveikatos priežiūros kokybė, socialinė gerovė, } \\
\text { ekologinè situacija, atsinaujinančioji energija. }\end{array}$ \\
\hline Produktų rinka & $\begin{array}{l}\text { Produktų rinkos efektyvumą nusakančios konkurencijos sąlygos: } \\
\text { procedūros, mokestinè ir teisinè bazè. }\end{array}$ \\
\hline Darbo rinka & $\begin{array}{l}\text { Darbo rinkos efektyvumas ir lankstumas: teisinè ir reguliavimo } \\
\text { sistema, rinkos dalyvių santykiai, našumas, talentų naudojimas, } \\
\text { lygios teisés. }\end{array}$ \\
\hline Finansų rinka & $\begin{array}{l}\text { Bankų ir vertybinių popierių rinkos veiklos efektyvumas, } \\
\text { prieinamumas ir patikimumas. }\end{array}$ \\
\hline Verslo pažanga & $\begin{array}{l}\text { Klasteriu plètra, įmonių atskaitomybè, valdymo praktika, kultūra, } \\
\text { strategijos. }\end{array}$ \\
\hline
\end{tabular}

Šaltinis: sudaryta autorès 


\subsection{Pirmojo skyriaus išvados}

1. Šalių poreikis atremti besikeičiančio pasaulio iššūkius praeito amžiaus antroje pusejje itin padidino šalies konkurencingumo klausimo aktualumą. Ieškodamos efektyvių sprendimų šalys pradejo steigti nacionalinio konkurencingumo tarybas, kurioms patikejo svarbų patariamaji vaidmenị sprendimu prièmimo procese. Pagrindinès šių tarybų funkcijos - šalies konkurencingumo vertinimas ir jo rezultatų pagrindu suformuotų rekomendacijų pateikimas už sprendimų prièmimą atsakingiems subjektams.

2. Šalių patirties analizė metodiniu aspektu atskleidžia, kad vertinant šalies konkurencingumą ne visada yra apibrezžiama šalies konkurencingumo samprata ir neretai naudojama silpnai teoriškai pagrịsta vertinimo metodika. Visa tai menkina už sprendimų prièmimą atsakingiems subjektams pateikiamų rekomendacijų pagrịstumą. Atsižvelgiant ị tai, šalies konkurencingumo vertinimas traktuojamas kaip nepakankamas šalies konkurencingumo sprendimų prièmimo pagrindas. Siekiant padidinti priimamų sprendimų pagrịstumą atsiranda naujų priemonių sukūrimo poreikis.

3. Mokslinès literatūros analizė atskleidžia tris požiūrius, skirtingai aiškinančius šalies konkurencingumą tam tikrais laikotarpiais: XVI-XVIII a. pradžioje gyvavo merkantilistų idejjos, pagal kurias šalies konkurencingumas buvo vertinamas atsižvelgiant i prekybos apimtis ir jos ekonominę naudą; XVIII-XX a. pradžioje klasikinès ekonomikos atstovai šalies konkurencingumą vertino produkcijos gamybos sąnaudomis; XX-XXI a. šalies konkurencingumas pradètas tapatinti su tokiais plètojamais ištekliais, kaip vadyba, inovacijos, žinios ir konkurencinga šalimi laikoma ta, kuri užtikrina savo gyventojams gyvenimo gerovę.

4. Šiandien vis dar paplitęs požiūris, šalies konkurencingumą tapatinantis su sẻkminga jos užsienio prekyba, yra netikslus, klaidinantis. Atsižvelgiant i kiekvienos šalies siekį užtikrinti savo gyventojams gerovę, prasmę igauna našumu grindžiama šalies konkurencingumo samprata, tačiau ji, kertiniu aspektu išlaikant šalies ekonominius laimejjimus, kurie garantuoja žmogui materialinę gerovę, turi būti papildyta ir neekonominiai, žmogaus gerovei taip pat svarbiais veiksniais. Atsižvelgiant i tai, šalies konkurencingumas apibrěžiamas kaip jos gebejjimas pasiekti aukštą našumą ir užtikrinti visapusišką gyventojų gerovę.

5. Mokslinèje literatūroje pateikiama pakankama teorinių šalies konkurencingumo veiksnių nustatymui naudotinų modelių bazé. M. E. Porter „deimanto“ modelis ir kiti jo pagrindu, siekiant padidinti jo pritaikymo galimybes, sukurti modeliai naudojami praktikoje siekiant sudaryti veiksniu rinkinius, skirtus šalies konkurencingumui vertinti. Universalius, teoriškai pagrịstus ir išsamius veiksnių rinkinius pateikia tokios organizacijos: Pasaulio ekonomikos forumas, Tarptautinis vadybos plètros institutas ir Pramonès politikos studijų institutas. 
6. Skirtingus veiksnių rinkinius sudarančių veiksnių sugrupavimas turinio požiūriu leido nustatyti priimtą konkurencingumo sampratą atitinkančius veiksnius. Tai: institucinè aplinka, makroekonominè situacija, inžinerinè infrastruktūra, technologinè infrastruktūra, mokslinè infrastruktūra, švietimas, socialinė aplinka, produktų rinka, darbo rinka, finansų rinka ir verslo pažanga. Gausus literatūros potencialas, kiekvieno veiksnio atžvilgiu, leido patvirtinti jų svarbą šalies konkurencingumui ir, atskleidžiant svarbiausius aspektus, apibrèžti turinị. 



\section{2}

\section{Šalies konkurencingumo vertinimas ir pokyčio optimizavimas}

Atsižvelgiant $\mathfrak{i}$ šalių patirties analizės metu atskleistą poreikị, skyriuje, ịvertinus šalies konkurencingumo skatinimo sprendimu pagristumo didinimo prielaidas, pasiūlomas šalies konkurencingumui vertinti skirtas metodas ir sudaromas šalies konkurencingumo pokyčio optimizavimo modelis. Skyriaus tema tarptautinèje konferencijoje skaitytas pranešimas (Staskevičiūtè ir Tamošiūnienè 2010) ir moksliniame žurnale publikuotas straipsnis (Rakauskienè, Tamošiūnienė 2013).

\section{1. Šalies konkurencingumo skatinimo sprendimų pagristumo didinimo prielaidos ir pagrindiniai spręstini klausimai}

Šalių patirties analizès metu atskleista šalies konkurencingumo vertinimui naudojamos metodikos problematika ir šalies konkurencingumo skatinimo sprendimu svarbumo suvokimas diktuoja sprendimų pagristumo ir efektyvumo didinimo poreikị. Siekiant patenkinti šį poreikį, siūlomas naujas požiūris i šalies konkurencingumo skatinimo sprendimų rengimo procesą (2.1 pav.). 


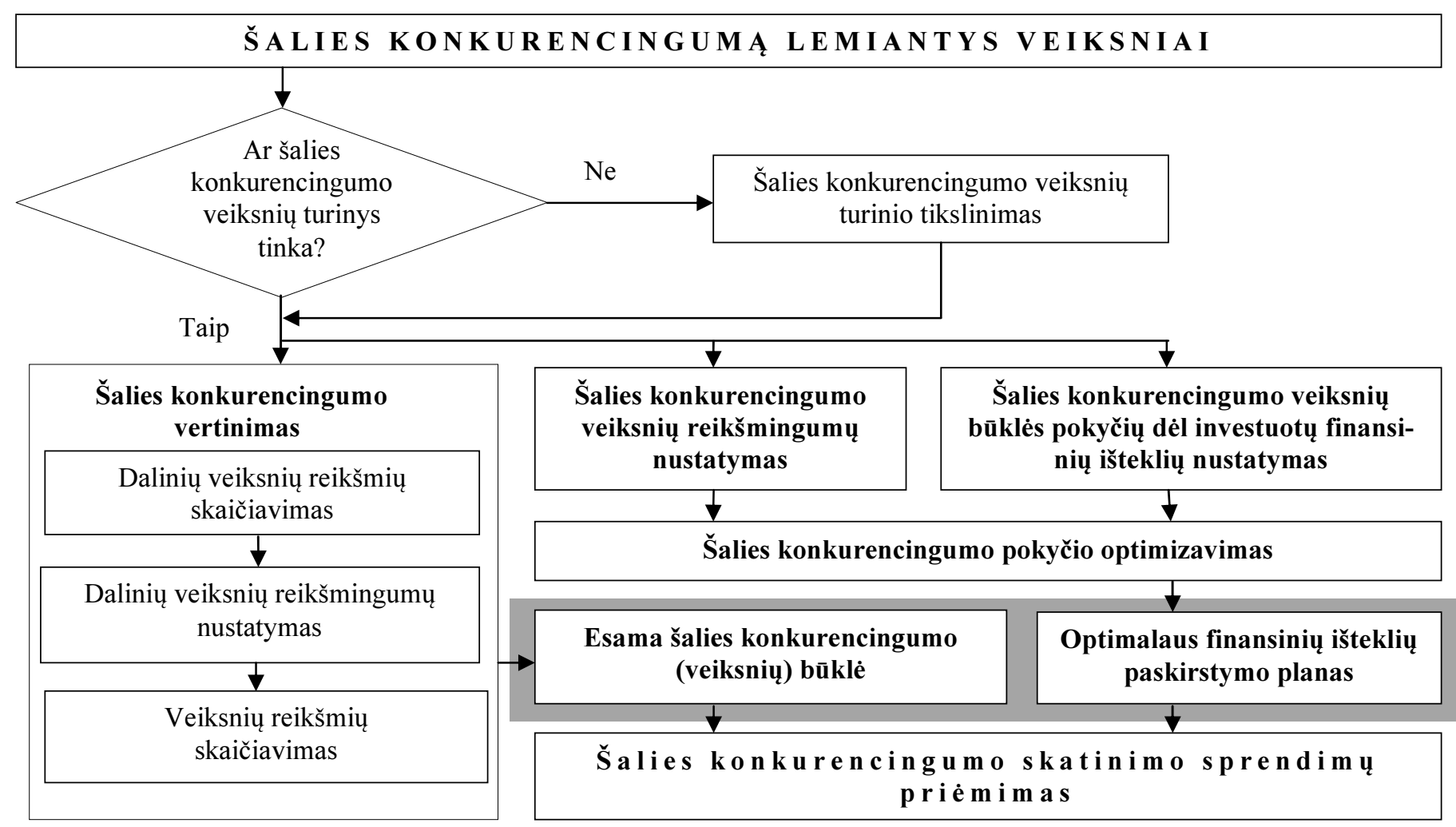

2.1 pav. Šalies konkurencingumo skatinimo sprendimų rengimo principinè schema

Fig. 2.1. The principal scheme of preparation of national competitiveness' promotion decisions

Šaltinis: sudaryta autorès 
Pagal siūlomą veiksmų schemą, šalies konkurencingumo skatinimo sprendimų rengimo pagrindą sudaro ne tik daugelyje šalių atliekamas konkurencingumo vertinimas, bet ir šalies konkurencingumo pokyčio optimizavimas. Šalies konkurencingumo pokyčio optimizavimo rezultatai pateikia optimalaus šalies konkurencingumo skatinimui skirtu finansinių išteklių paskirstymo tarp šalies konkurencingumą lemiančių veiksnių planą, kuri iggyvendinus būtų pasiektas didžiausias (optimalus) šalies konkurencingumo augimas.

Šalies konkurencingumo skatinimo sprendimu prièmimas. I̦vairių šalių valdžios atstovai, siekdami šalies konkurencingumo didejjimo, atsižvelgia ị esamą šalies konkurencingumą lemiančių veiksnių būklę ir priima sprendimus, susijusius su tos būklès gerinimu. Šiu sprendimų igyvendinimui toliau yra kuriamos priemonès, kurios daugiau ar mažiau priklauso nuo finansinių išteklių. Pagal tokią logiką, šalies konkurencingumo sprendimų prièmimo procesas gali būti suvokiamas kaip tikslingai tam skirtu finansinių išteklių nukreipimas i konkurencingumą lemiančius veiksnius, tikintis jų būklès pagerèjimo ir, dèl to, šalies konkurencingumo didejjimo (2.2 pav.).

\section{Š ALIES KONKURENCINGUMAS}

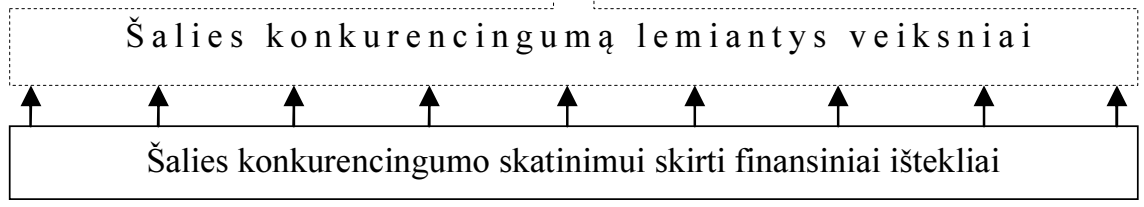

2.2 pav. Šalies konkurencingumo sprendimų prièmimo koncepcija

Fig. 2.2 The conception of national competitiveness decision-making Šaltinis: sudaryta autorès

Pagal tokią šalies konkurencingumo sprendimų prièmimo koncepciją, pagrindine sprendimų prièmime problema laikytina šalies konkurencingumui skirtų finansinių išteklių, kurie kaip ir bet kuriai kitai sričiai yra riboti, efektyvus paskirstymas. Kaip atskleide šalių patirties analizė, konkurencingumo skatinimui skirtų sprendimu prièmimo pagrindas yra šalies konkurencingumo vertinimas. Tokiu atveju, priimant sprendimus yra atsižvelgiama i vertinimo rezultatus ir finansiniai ištekliai nukreipiami priemonių, skirtų pagerinti blogiau įvertintų šalies konkurencingumo veiksnių būklę, kūrimui ir igyvendinimui. Tačiau toks priimamų sprendimų pagrindas, tiek dèl nustatytų metodinių problemų, tiek dèl priimamų sprendimų svarbumo lygio, vertintinas kaip per menkas. Priimant šalies konkurencingumo skatinimo sprendimus svarbūs yra ir tokie aspektai kaip šalies konkurencingumą lemiančių veiksnių svarba bendram konkurencingumui bei veiksnių būklès pokyčio dèl ị juos investuotų finansinių išteklių dydis. Ži- 
nant šiuos aspektus gali būti parengtas optimalaus finansinių išteklių, skirtų šalies konkurencingumo skatinimui, paskirstymo tarp šalies konkurencingumą lemiančių veiksnių planas, kuris, sustiprindamas šalies konkurencingumo sprendimų prièmimo pagrindą, padidintų priimamų sprendimų pagrịstumą ir efektyvumą.

Šalies konkurencingumo vertinimas. Šalių patirtis rodo, kad kaip pagrindas priimant šalies konkurencingumo skatinimo sprendimus yra atliekamas konkurencingumo veiksnių būklès vertinimas, parodantis bendrą šalies konkurencingumo būklę. Tačiau nustatytos šalies konkurencingumui vertinti taikomos metodikos problemos kelia grèsmę atliekamo vertinimo tikslumui ir taip menkina priimtų sprendimų pagrịstumą. Siekiant išvengti esančių problemų, šalies konkurencingui vertinti tikslinga pasitelkti darbe pasiūlytą šalies konkurencingumą lemiančių veiksnių rinkinį, kuris sudarytas remiantis patikslintu šalies konkurencingumo apibrežimu ir pasaulyje pripažintų šalies konkurencingumo veiksnių rinkinių ir mokslinès literatūros analize. Vertinimo tikslumui padidinti, taip pat tikslinga, atsižvelgiant ị konkrečios šalies ypatumus, detalizuoti kiekvieno veiksnio turinị ir, atsižvelgiant ị skirtingą veiksnių svarbą, nustatyti veiksnių ir juos sudarančių dalinių veiksnių reikšmingumus.

Šalies konkurencingumo pokyčio optimizavimas. Siekis sudaryti optimalaus finansinių išteklių paskirstymo planą, kuris parodytų kokiomis dalimis turimi finansiniai ištekliai gali būti paskirstyti tarp šalies konkurencingumą lemiančių veiksnių, kad būtų pasiektas optimalus šalies konkurencingumo padidejjimas, kelia šalies konkurencingumo pokyčio optimizavimo uždavinio išsprendimo poreiki. Šalies konkurencingumo pokyčio optimizavimo uždavinio sprendimui, pasitelkiant matematinio programavimo metodus, bus sudarytas šalies konkurencingumo pokyčio optimizavimo modelis. Modelio sudarymui svarbūs yra tokie klausimai: šalies konkurencingumą lemiančių veiksnių reikšmingumų nustatymas ir šalies konkurencingumą lemiančių veiksnių būklès pagerejimo (pokyčių) dèl i juos investuotų finansinių išteklių nustatymas.

Salies konkurencinguma lemiantys veiksniai. Mokslinès ir praktinès literatūros analizès metu nustatyti ir pagrịsti 11 šalies konkurencingumą lemiančiu veiksnių: instituciné aplinka, makroekonominè situacija, inžinerinè infrastruktūra, technologinè infrastruktūra, mokslinè infrastruktūra, švietimas, socialinė aplinka, produktų rinka, darbo rinka, finansų rinka ir verslo pažanga. Priimant sprendimą dèl galutinio veiksnių rinkinio sudarymo, pasiūlyta šalies konkurencingumo sprendimu prièmimo koncepcija ir šalies konkurencingumo pokyčio optimizavimo modelio ideja - optimaliai paskirstyti turimus finansinius išteklius tarp šalies konkurencingumą lemiančių veiksnių - skatina atsižvelgti ị skirtingo veiksnių poreikio finansiniams ištekliams buvimą. Vertinant nustatytus veiksnius pagal jų poreikị tiesioginėms investicijoms, abejonių kyla tik dèl makroekonominès situacijos veiksnio. Šio veiksnio turinį nusakantiems tokiems aspek- 
tams kaip fiskalinè politika, monetarinè politika ir viešieji finansai svarią įtaką turi ne finansiniai ištekliai, o valdžios atstovų priimami sprendimai, jų vykdoma politika ir atstovaujama ideologija. Nuo to, kaip veiksmingai dirbs, gebès kurti ir igyvendinti efektyvią ir patikimą politiką valdžios atstovai, kitaip tariant, nuo to, kokia bus institucinès aplinkos būklè, priklausys ir šalies makroekonominis stabilumas. Atsižvelgiant $\mathfrak{i}$ išdèstytus argumentus, makroekonominès situacijos veiksnys traktuojamas kaip rezultatas, kuris iš esmès priklauso nuo institucinès aplinkos veiksnio būklès ir ị šalies konkurencingumą lemiančių veiksnių sąrašą nèra įtraukiamas.

\section{2. Šalies konkurencingumo vertinimo metodas}

Dèl šalies konkurencingumo vertinimo svarbos abejonių nekyla, todèl jis, kaip viena šalies konkurencingumo skatinimo sprendimu prièmimo pagrindo dedamųjų, turi būti sprendimų rengimo procese.

Mokslinès (Cho 1994; Moon et al. 1995; Porter 1990; Snieška ir Šliburytė 2000; Lall 2001; Maksvytienè ir Urbonas 2001; Kvainauskaite ir Snieška 2002; Ginevičius 2004; Wilson 2008; Rutkauskas 2008; Ginevičius ir Podvezko 2009) ir praktinès literatūros analizè atskleidžia, kad šalies konkurencingumas gali būti vertinamas ịvairiais būdais: analizuojant pavienius, tam tikras sritis apibūdinančius rodiklius; naudojant konkurencingumo teorinius modelius; kuriant integruotus kompleksinius rodiklius.

Dažniausiai šalies konkurencingumo vertinimui pasitelkiami rodikliai, apibūdinantys tam tikras sritis ir išreiškiantys savitą požiūrị i konkurencingumą, pvz. BVP tenkantis vienam gyventojui, valiutos kursas, palūkanų norma, užsienio prekybos balansas, konkurencijos intensyvumo lygis skirtingose rinkose, verslo struktūra ar rinkos paklausa ir kt. Taip pat praktikoje plačiai naudojami pirmoje darbo dalyje aptarti teoriniai šalies konkurencingumo modeliai, leidžiantys nustatyti šalies konkurencingumą lemiančius veiksnius, kurių kiekybiniam vertinimui toliau priimami juos apibūdinantys rodikliai. Pasaulyje pripažintos organizacijos (pvz. Pasaulio ekonomikos forumas) šalių konkurencingumo vertinimus atlieka pasitelkdamos integruotus kompleksinius rodiklius (indeksus), apimančius daugybę šalies konkurencingumą apibūdinančių kiekybinių ir kokybinių rodiklių.

Atsižvelgiant i šalies konkurencingumo sąvokos daugiaaspektiškumą, kuris pasireiškia apimdamas ịvairius šalies gyventojų gerovę lemiančius ekonominius, socialinius ir ekologinius veiksnius, konkurencingumo vertinimas turi apimti daugybę, šiuos veiksnius apibūdinančių rodiklių. Todèl priimamas sprendimas šalies konkurencingumo (veiksnių) būklès vertinimui sudaryti integruotus kompleksinius rodiklius. 
Svarbu pažymèti, kad šalies konkurencingumo (veiksnių) rodiklių tikslas nèra, kaip įprasta, palyginti šalies konkurencingumą su kitomis šalimis, o - gauti kiekybinę esamos šalies konkurencingumo (veiksnių) būklès išraišką (-as). Šalies konkurencingumo veiksnių vertinimas, nustatant jų kiekybines reikšmes, turi pasitarnauti priimant šalies konkurencingumo sprendimus, o bendras šalies konkurencingumo įvertis - priimamų šalies konkurencingumo sprendimų efektyvumo vertinimui.

Remiantis moksline literatūra (Booysen 2002; Freudenberg 2003; Nardo et al. 2005; Viassone 2008; Snieška, Bruneckienè 2009) integruoti kompleksiniai rodikliai sudaromi vadovaujantis tokia veiksmų seka:

1. Teorinio pagrindo formavimas.

2. Veiksnių nustatymas.

3. Veiksnių turinio detalizavimas.

4. Veiksnius apibūdinančių rodiklių nustatymas.

5. Veiksnius apibūdinančių rodiklių normalizavimas.

6. Veiksnių reikšmingumų nustatymas.

7. Šalies konkurencingumo veiksnių ir bendro konkurencingumo integruotų kompleksinių rodiklių funkcijų sudarymas.

Teorinis pagrindas suformuotas pirmoje darbo dalyje, kur atlikus mokslinès literatūros analizę priimtas šalies konkurencingumo apibrèžimas ir nustatyti bei, remiantis mokslinès literatūros analize, pagrịsti priimtą šalies konkurencingumo apibrèžimą atitinkantys veiksniai. Toliau, atsižvelgiant i, šalies konkurencingumui vertinti naudojamų veiksnių rinkinių ir mokslinès literatūros analizès metu atskleistus, svarbiausius aspektus, detalizuojamas veiksnių turinys. Siūlomas priimtų šalies konkurencingumo veiksnių turinį atskleidžiančių dalinių veiksnių sąrašas pateiktas 2.1 lentelejje.

2.1 lentelè. Šalies konkurencingumą lemiančių veiksnių turinio detalizavimas

Table 2.1. Specification of the content of national competitiveness' factors

\begin{tabular}{|c|c|c|c|}
\hline \multicolumn{2}{|l|}{ Veiksniai } & \multicolumn{2}{|l|}{ Daliniai veiksniai } \\
\hline $\begin{array}{l}\text { Institucinè } \\
\text { aplinka }\end{array}$ & $V_{1}$ & $\begin{array}{l}\text { - } \text { teisès viršenybė; } \\
\text { - } \quad \text { korupcijos mastas; } \\
\text { - reguliavimo kokybė; } \\
\text { - } \quad \text { valdžios veiksmingumas; }\end{array}$ & $\begin{array}{l}v_{11} \\
v_{12} \\
v_{13} \\
v_{14}\end{array}$ \\
\hline $\begin{array}{l}\text { Inžinerinè } \\
\text { infrastruktūra }\end{array}$ & $V_{2}$ & $\begin{array}{l}\text { - } \quad \text { keliú tinklo infrastruktūra; } \\
\text { - geležinkelių infrastruktūra; } \\
\text { - } \text { oro transporto infrastruktūra; } \\
\text { - vandens transporto infrastruktūra; } \\
\text { - energijos perdavimo infrastruktūra; }\end{array}$ & $\begin{array}{l}v_{21} \\
v_{22} \\
v_{23} \\
v_{24} \\
v_{25}\end{array}$ \\
\hline $\begin{array}{l}\text { Technologinè } \\
\text { infrastruktūra }\end{array}$ & $V_{3}$ & $\begin{array}{l}\text { - fiksuoto telefono ryšio prieinamumas; } \\
\text { - judriojo telefono ryšio paplitimas; }\end{array}$ & $\begin{array}{l}v_{31} \\
v_{32}\end{array}$ \\
\hline
\end{tabular}


2.1 lentelès pabaiga

\begin{tabular}{|c|c|c|c|}
\hline \multicolumn{2}{|l|}{ Veiksniai } & \multicolumn{2}{|l|}{ Daliniai veiksniai } \\
\hline $\begin{array}{l}\text { Technologinè } \\
\text { infrastruktūra }\end{array}$ & $V_{3}$ & $\begin{array}{l}\text { - } \quad \text { interneto naudojimas; } \\
\text { - } \text { plačiajuosčio ryšio prieinamumas; } \\
\text { - naujausių technologijų prieinamumas; } \\
\text { - naujausių technologijų diegimas; }\end{array}$ & $\begin{array}{l}v_{33} \\
v_{34} \\
v_{35} \\
v_{36}\end{array}$ \\
\hline $\begin{array}{l}\text { Mokslinè } \\
\text { infrastruktūra }\end{array}$ & $V_{4}$ & $\begin{array}{ll}\text { - } & \text { inovacijų kūrimo pajègumai; } \\
\text { - } & \text { mokslinių tyrimu institucijų kokybė; } \\
\text { - } & \text { universitetų ir verslo bendradarbiavimas; } \\
\text { - } & \text { išradimų patentai; } \\
\text { - } & \text { žmogiškieji ištekliai mokslinejje veikloje; }\end{array}$ & $\begin{array}{l}v_{41} \\
v_{42} \\
v_{43} \\
v_{44} \\
v_{45}\end{array}$ \\
\hline Švietimas & $V_{5}$ & $\begin{array}{l}\text { - } \text { pradinis ugdymas; } \\
\text { - aukštesnis mokymas; } \\
\text { - aukštasis mokslas; } \\
\text { - darbuotojų mokymai; }\end{array}$ & $\begin{array}{l}v_{51} \\
v_{52} \\
v_{53} \\
v_{54}\end{array}$ \\
\hline $\begin{array}{l}\text { Socialinè } \\
\text { aplinka }\end{array}$ & $V_{6}$ & $\begin{array}{l}\text { - } \text { gyvenimo trukmé; } \\
\text { - } \quad \text { kūdikių mirtingumas; } \\
\text { - } \quad \text { ligų paplitimas; } \\
\text { - } \quad \text { sveikatos priežiūra; } \\
\text { - } \quad \text { skurdas ir socialinė atskirtis; } \\
\text { - } \quad \text { oro kokybė; } \\
\text { - } \quad \text { atliekų perdirbimas; } \\
\text { - } \quad \text { atsinaujinančioji energija; }\end{array}$ & $\begin{array}{l}v_{61} \\
v_{62} \\
v_{63} \\
v_{64} \\
v_{65} \\
v_{66} \\
v_{67} \\
v_{68}\end{array}$ \\
\hline $\begin{array}{l}\text { Produktų } \\
\text { rinka }\end{array}$ & $V_{7}$ & $\begin{array}{l}\text { - } \quad \text { verslo pradžios procedūros; } \\
\text { - } \quad \text { mokesčių mokèjimai; } \\
\text { - } \quad \text { prekybos laisvė; } \\
\text { - } \quad \text { investavimo laisvė; } \\
\end{array}$ & $\begin{array}{l}v_{71} \\
v_{72} \\
v_{73} \\
v_{74}\end{array}$ \\
\hline $\begin{array}{l}\text { Darbo } \\
\text { rinka }\end{array}$ & $V_{8}$ & $\begin{array}{l}\text { - } \text { darbo jėgos laisvė; } \\
\text { - darbdavių ir darbuotojų santykiai; } \\
\text { - užmokestis ir našumas; } \\
\text { - } \quad \text { protų nutekejjimas; } \\
\text { - } \quad \text { moterys darbo rinkoje; }\end{array}$ & $\begin{array}{l}v_{81} \\
v_{82} \\
v_{83} \\
v_{84} \\
v_{85}\end{array}$ \\
\hline $\begin{array}{l}\text { Finansur } \\
\text { rinka }\end{array}$ & $V_{9}$ & $\begin{array}{l}\text { - } \quad \text { finansinių paslaugų prieinamumas; } \\
\text { - vertybinių popierių rinkos veikla; } \\
\text { - finansų rinkos patikimumas; } \\
\text { - finansų valdymas; }\end{array}$ & $\begin{array}{l}v_{91} \\
v_{92} \\
v_{93} \\
v_{94}\end{array}$ \\
\hline $\begin{array}{l}\text { Verslo } \\
\text { pažanga }\end{array}$ & $V_{10}$ & $\begin{array}{l}\text { - klasterių plètra; } \\
\text { - imonių atskaitomybe; } \\
\text { - imonių valdymas; } \\
\text { - } \quad \text { verslo kultūra; } \\
\text { - } \quad \text { strategija ir operacijos. }\end{array}$ & $\begin{array}{l}v_{101} \\
v_{102} \\
v_{103} \\
v_{104} \\
v_{105}\end{array}$ \\
\hline
\end{tabular}

Saltinis: sudaryta autorès 
Svarbu pažymèti, kad pateikiamas šalies konkurencingumą lemiančių veiksnių turini detalizuojantis dalinių veiksnių sąrašas yra sudarytas remiantis Lietuvos atveju. Todèl jis tinkamas savo išsivystymo lygiu, infrastruktūra ir kitais aspektais panašių šalių konkurencingumui vertinti. Atliekant kitame plètros etape esančių ar kitas išsiskiriančias ypatybes turinčių šalių konkurencingumo vertinimą, sąrašas turètų būti tikslinamas įtraukiant svarbius arba eliminuojant nereikšmingus vertinamai šaliai aspektus.

Dalinių veiksnių reikšmėms apskaičiuoti sudarytas juos apibūdinančių rodiklių sąrašas (A priedas). Siekiant išlaikyti kiek įmanoma didesnį objektyvumą, atrenkant dalinius veiksnius apibūdinančius rodiklius pirmenybe buvo teikiama kiekybiniams santykiniams rodikliams. Nesant galimybès vertinamą aspektą išreikšti kiekybiškai, pasitelkiami kokybiniai rodikliai, kurių gausų pasirinkimą pateikia šalies konkurencingumą vertinančios organizacijos. Taip pat, atsižvelgiant ị kai kurių dalinių veiksnių daugiaaspektiškumą, jiems vertinti yra pasitelkiami pasaulyje jau pripažinti, tam tikras sritis apibūdinantys integruoti kompleksiniai rodikliai. Atrenkant dalinius šalies konkurencingumo veiksnius apibūdinančius kiekybinius ir integruotus kompleksinius rodiklius, atsakingai buvo įvertinamos jų prieinamumo galimybès. Priimti tie rodikliai, kurių statistiką viešai pateikia gerai pasaulyje žinomos organizacijos, tokios kaip Pasaulio bankas, Europos Sajungos statistikos tarnyba, Ekonominio bendradarbiavimo ir pletros organizacija ir kt.

Kiekybiniai dalinius veiksnius apibūdinantys rodikliai tarpusavyje skiriasi ivairiais matavimo vienetais, todèl, siekiant atlikti tolimesnius skaičiavimus, jie normalizuojami, t. y. perskaičiuojami i bemati pavidalą. Rodikliai normalizuojami taip, kad igautų reikšmes intervale $[0,1]$. Normalizavimui taikomos neretai sudarant integruotus kompleksinius rodiklius naudojamos (Freudenberg 2003; Nardo et al. 2005) formulès:

maksimizuojančių rodiklių reikšmėms

$$
\widetilde{R}_{j}=\frac{R_{j}-\min (R)}{\max (R)-\min (R)} ;
$$

minimizuojančių rodiklių reikšmėms

$$
\widetilde{R}_{j}=\frac{\max (R)-R_{j}}{\max (R)-\min (R)},
$$

čia $\widetilde{R}_{j}$ - normalizuota rodiklio reikšmé; $\max (R)$ - didžiausia galima rodiklio reikšmé; $R_{j}$ - tikroji rodiklio reikšmè; $\min (R)$ - mažiausia galima rodiklio reikšmè. 
Šalies konkurencingumo dalinių veiksnių reikšmių skaičiavimui priimti kokybiniai rodikliai gaunami atliekant ekspertini vertinimą. Ekspertai vertinamam aspektui suteikia reikšmes intervale $[0,1]$. Geriausiam ìvertinimui skiriama 1 reikšmè, o blogiausiam ịvertinimui - 0 reikšmè. Pavyzdžiui, vertinant naujausių technologijų prieinamumą Lietuvoje, „visiškas neprieinamumas“ igaus 0 reikmę, o „labai aukštas prieinamumo lygis“ - 1 reikšmę. Siekiant kuo tiksliau ịvertinti aspektus ir suvokiant, kad jie retai atitinka ribines 0 ir 1 reikšmes, naudojamos tarpinès reikšmès, pvz., „vidutinis prieinamumas“- 0,5; ,nepakankamas prieinamumas“ $-0,3$; ,mažas prieinamumas“ $-0,2$ ir t. t., interpretuojant jas intervale $[0,1]$ pagal logikos principus.

Siekiant kuo išsamiau apibūdinti kai kuriuos dalinius veiksnius, priimamas daugiau negu vienas rodiklis. Kadangi jie yra vienodai svarbūs ir vienas kitą papildantys, integruojant juos ị vieną rodikli, jų reikšmès sudedamos ir apskaičiuojamas paprastas aritmetinis vidurkis.

Remiantis pasaulyje pripažintų šalių konkurencingumo vertinimus atliekančių organizacijų, tokių kaip Pasaulio ekonomikos forumas, praktika, konkurencingumo veiksnių $\left(V_{j}\right)$ ir šalies konkurencingumo $(K)$ integruotų kompleksinių rodiklių skaičiavimui sudaromos tokios formulès:

$$
V_{j}=\sum_{i=1}^{m_{j}} w_{j i} v_{j i} ; \quad \sum_{i=1}^{m_{j}} w_{j i}=1
$$

čia $w_{j i}-j$-ojo veiksnio $i$-ojo dalinio veiksnio santykinis reikšmingumas; $v_{j i}-$ $j$-ojo veiksnio $i$-asis dalinis veiksnys; $m_{j}-j$-ajị veiksnį sudarančių dalinių veiksnių skaičius;

$$
K=\sum_{j=1}^{n} w_{j} V_{j} ; \sum_{j=1}^{n} w_{j}=1
$$

čia $w_{j}-j$-ojo veiksnio santykinis reikšmingumas; $V_{j}$-j-asis veiksnys; $n$ - veiksnių skaičius.

Pagal pateiktą 2.3 formulę apskaičiuotos šalies konkurencingumą lemiančių veiksnių reikšmès už sprendimų prièmimą atsakingiems subjektams suteiks informacijos apie esamą veiksnių būklę. Pagal 2.4 formulę apskaičiuota šalies konkurencingumo reikšmé, be to, kad parodys bendrą konkurencingumo būklę, pasitarnaus kaip priemonè priimtų sprendimų efektyvumui nustatyti. 


\section{3. Šalies konkurencingumą lemiančių veiksnių reikšmingumų nustatymas}

Siekiant atlikti galimai tikslesni šalies konkurencingumo vertinimą ir išspręsti šalies konkurencingumo pokyčio optimizavimo uždavini, svarbu nustatyti šalies konkurencingumo veiksnių ir juos sudarančių dalinių veiksnių reikšmingumus. Nustatytas tam tikrą veiksni apibūdinančio dalinio veiksnio reikšmingumas parodys kiek jo svarba tam veiksniui yra didesnè ar mažesnè lyginant su kitu daliniu veiksniu. Analogiškai, konkretaus šalies konkurencingumo veiksnio reikšmingumas parodys kiek jo svarba, lyginant su kitu veiksniu, yra didesnè ar mažesnè bendram šalies konkurencingumui.

Atlikdamos šalių konkurencingumo vertinimus, ivairios organizacijos, savo metodikose naudodamos skirtingus veiksnių rinkinius, taip pat numato skirtingus veiksnių reikšmingumų nustatymo principus. Pavyzdžiui, Pasaulio ekonomikos forumas, remdamasis M. E. Porter ,plètros stadiju“ teorija, didesnius reikšmingumus suteikia subindeksams, kurie apima veiksnių grupes, svarbiausias vertinimo metu tam tikroje plètros stadijoje esančiai šaliai. Veiksnių grupèms, patenkančioms i tam tikrą subindeksą, yra suteikti vienodi reikšmingumai, o jas sudarantiems veiksniams - skirtingi. Veiksnius apibūdinantys daliniai veiksniai taip pat turi vienodus reikšmingumus.

Pramonès politikos studijų institutas šalies konkurencingumą apibūdinantiems veiksniams ir veiksniu grupėms taip pat suteikia skirtingus reikšmingumus. Veiksniu grupèms reik-šmingumai suteikiami atsižvelgiant į dvi skirtingas šalies konkurencingumo strategijas - sąnaudų lyderystès ir diferenciacijos. Vertinant šalies konkurencingumą, šiai taikant sąnaudų lyderystès strategiją, didesni reikšmingumai suteikiami tokioms kainai svarbioms veiksnių grupėms kaip veiksniu sąlygos ir darbuotojai, o taikant diferenciacijos strategiją - paklausos sąlygoms ir profesionalams.

Tarptautinis vadybos plètros institutas priima vienodus visiems veiksniams reikšmingumus. Toks sprendimas supaprastina šalies konkurencingumo vertinimą, tačiau, tuo pat metu, neatsižvelgimas ì skirtingą šalies konkurencingumą lemiančiu veiksniu reikšmingumą sumenkina vertinimo tikslumą, dèl ko kyla grèsmè priimamų sprendimų pagrịstumui. Atsižvelgiant ị tai, atskiras šalies konkurencingumą lemiančių veiksnių reikšmingumų nustatymas traktuojamas kaip būtina sąlyga vertinimo tikslumui padidinti.

Renkantis tinkamiausią veiksnių reikšmingumų nustatymo metodą, atlikta mokslinès literatūros šia tema analizè (Saaty 2005, 2008; Zavadskas et al. 2001; Ginevičius ir Podvezko 2004, 2005, 2009; Ginevičius 2006; Podvezko 2008, 2009; Zavadskas ir Turskis 2011). Analizės metu atskleista reikšmingumų nustatymo metodų įvairove leidžia apibendrinti tokius juos vienijančius principus:

- reikšmingumų nustatymo pagrindas yra ekspertinis vertinimas; 
- vertinimo logika: svarbiausias $j$-tasis veiksnys turès didžiausią reikšmingumą $w_{j}$. Bendra reikšmingumų suma lygi vienetui:

$$
\sum_{j=1}^{n} w_{j}=1
$$

Dažniausiai naudojamų reikšmingumų nustatymo metodų pagrindas yra ekspertinis vertinimas, kuris, kaip vienintelè galimybe ịvertinti kiekybiškai neišmatuojamus reiškinius, ivvairiose srityse taikomas vis dažniau. Ir nors dèl jiems būdingo subjektyvumo ekspertiniai vertinimai nèra visiškai patikimi, šiandien mokslininkai (Maknickienè et al. 2011; Rutkauskas et al. 2011) sutinka, kad jie yra veiksnūs.

Pats paprasčiausias iš reikšmingumų nustatymui taikomų metodų yra veiksnių rangavimas - procedūra, kai pačiam svarbiausiam veiksniui ekspertai suteikia rangą, lygų 1, antram pagal svarbumą - rangą 2, paskutiniam pagal svarbumą - rangą $n$ ( $n$ - lyginamų veiksnių skaičius). Ekvivalentiniams veiksniams suteikiama vienoda reikšme - eilinių rangų aritmetinis vidurkis. Šis metodas yra logiškas, aiškus, lengvai taikomas praktikoje, tačiau jo tikslumas yra mažas, todèl ji rekomenduojama taikyti tais atvejais, kai veiksnių reikšmingumai neturi didelès ittakos vertinimo rezultatams. Pasak V. Podvezko (2005, 2007, 2008), rangavimas taip pat rekomenduojamas kai yra taikomi sudetingesni veiksnių reikšmingumų nustatymo metodai, kai norima nustatyti ekspertų vertinimų nuomonių suderinamumą ir skaičiuojant konkordancijos koeficientą.

Siekiant pasirinkti tinkamą veiksniu reikšmingumų nustatymo metodą, kad būtų išlaikyta tikslumo sąlyga, svarbu atsižvelgti ị veiksnių skaičių. Esant nedideliam veiksnių skaičiui paprasčiausia ir racionaliausia, pasak R. Ginevičiaus (2006), taikyti tiesiogini vertinimą, kai ekspertai vieneto dalimis iškarto nurodo veiksnių reikšmingumus. Pagal ši metodą, kiekvieno eksperto visų vertinimų reikšmingumų suma turi būti lygi vienetui (Ginevičius ir Podvezko 2004; Podvezko 2008). Šio metodo taikymo praktika parode, kad jis yra lengvai suprantamas ir duoda palyginti tikslų reikšmingumų vertinimo rezultatą, kai ekspertų grupès nuomonès suderintos. Tačiau, pasak R. Ginevičiaus (2006), toks būdas visiškai netinka kai yra didelis skaičius veiksnių, nes ekspertui sunku nustatyti teisingus veiksnių tarpusavio santykius nagrinejjamo reiškinio atžvilgiu. Dèl to didèja nuomonių nesuderinamumas, dažnai jis viršija leistinąsias ribas ir ekspertų apklausos rezultatai tampa netinkamais tolimesniems skaičiavimams.

Minètų problemų galima išvengti reikšmingumų nustatymui taikant T. L. Saaty sukurtą analitinès hierarchijos proceso metodą (AHP metodas). AHP metodas suteikia galimybę nustatyti vieno lygio hierarchijos veiksnių reikšmingumus aukštesnio lygio atžvilgiu. Metodas paremtas apibrèžta matematinių matricų struktūra, kur atliekamas veiksnių lyginimas poriniu būdu. Vertinimui taiko- 
mi individualūs reikšmingumai gaunami panaudojant santykių skalę, ekspertiniu vertinimu nustatant vieno veiksnio dominavimą kito atžvilgiu.

Matematinis AHP metodo pagrindimas sudaro prielaidas didesniam objektyvumui. Dèl to ir dèl lengvo jo pritaikomumo ši metodą savo tyrimuose taiko vis daugiau Lietuvos mokslininkų (Zinkevičiūtè 2006; Tvaronavičienè et al. 2008; Ginevičius ir Podvezko 2009; Morkvènas 2010; Tupenaitè 2010; Medineckienè et al. 2010; Sivilevičius ir Maskeliūnaitė 2010; Zavadskas et al. 2011; Vaidogas ir Šakènaite 2011; Poškas et al. 2012; Ginevičius et al. 2012). Atsižvelgiant ị šio metodo matematini pagrịstumą ir lengvą pritaikomumą jis pasirenkamas ir šalies konkurencingumo veiksnių reikšmingumų nustatymui.

2.3 paveiksle pateikiama veiksnių reikšmingumų nustatymo principinè veiksmų schema.

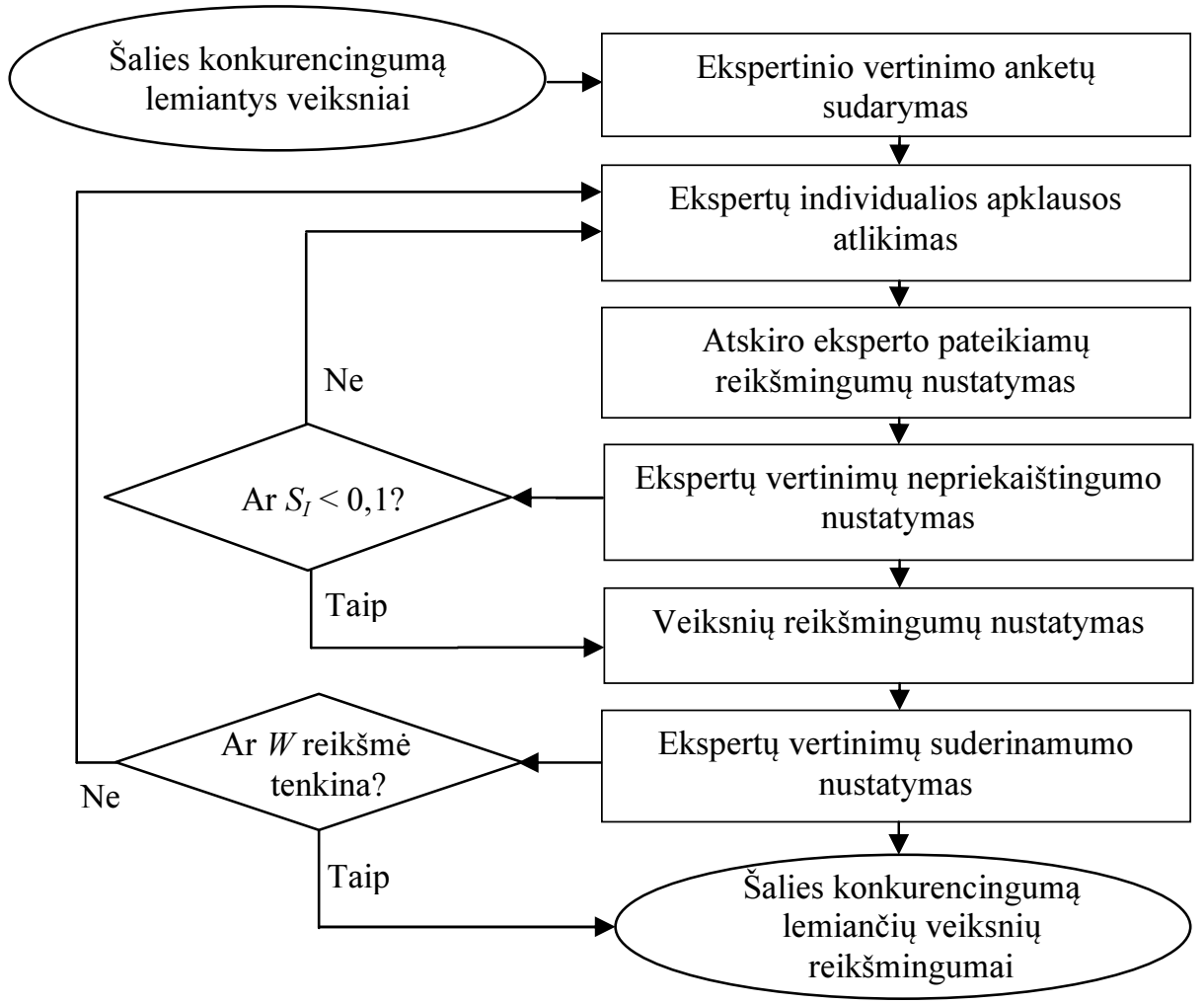

2.3 pav. Veiksnių reikšmingumų nustatymo principinė veiksmų schema

Fig. 2.3. The principal scheme of factors' significances evaluation Saltinis: sudaryta autores remiantis AHP metodo teorija 
Pagal AHP metodą atliekamo vertinimo metu tarpusavyje yra lyginami visi vertinami veiksniai $V_{i}$ ir $V_{j}(i, j=1,2, \ldots, n$, čia $n$-lyginamų veiksnių skaičius). Veiksniai lyginami nurodant, ar vienas veiksnys yra svarbesnis už kitą. Gautas palyginimo rezultatas yra kvadratinè matrica $P=\left[p_{i j}\right](i, j=1,2, \ldots, n$, čia $n-$ veiksnių skaičius):

$$
P=\left[\begin{array}{cccc}
p_{11} & p_{12} & \cdots & p_{1 n} \\
p_{21} & p_{22} & \cdots & p_{2 n} \\
\vdots & \vdots & \cdots & \vdots \\
p_{n 1} & p_{n 2} & \cdots & p_{n n}
\end{array}\right]=\left[\begin{array}{cccc}
\frac{w_{1}}{w_{1}} & \frac{w_{1}}{w_{2}} & \cdots & \frac{w_{1}}{w_{n}} \\
\frac{w_{2}}{w_{1}} & \frac{w_{2}}{w_{2}} & \cdots & \frac{w_{2}}{w_{n}} \\
\vdots & \vdots & \cdots & \vdots \\
\frac{w_{n}}{w_{1}} & \frac{w_{n}}{w_{2}} & \cdots & \frac{w_{n}}{w_{n}}
\end{array}\right] .
$$

Nežinomoms $w_{l}, w_{2}, \ldots w_{n}$ reikšmėms gauti naudojamasi T. L. Saaty (1990, 2008) pasiūlyta penkių balų skale (2.2 lentelè).

2.2. lentelè. Veiksnių reikšmingumų vertinimo skalè

Table 2.2. The scale of factors' significances evaluation

\begin{tabular}{|c|l|}
\hline Ivertis & \multicolumn{1}{c|}{ Paaiškinimas } \\
\hline 1 & Abiejų veiksnių i̇taka tikslo pasiekimui yra vienoda \\
\hline 3 & Vieno veiksnio ịtaka, lyginant su kitu, yra labai nežymiai didesnė \\
\hline 5 & Vieno veiksnio i̇taka, lyginant su kitu, yra nežymiai didesnė \\
\hline 7 & Vieno veiksnio ịtaka, lyginant su kitu, yra žymiai didesnė \\
\hline 9 & Vieno veiksnio ịtaka, lyginant su kitu, yra labai žymiai didesnè \\
\hline $2,4,6,8$ & Tarpinės reikšmès naudojamos kompromiso atveju \\
\hline
\end{tabular}

Šaltinis: sudaryta autorès remiantis Saaty 2008

Veiksnių porinis lyginimas pradedamas nuo kairiojo matricos veiksnio keliant klausimą kiek jis yra svarbesnis už veiksnị esantị viršuje. Lyginant veiksnị pati su savim visada gaunamas vienetas. Jei pirmasis veiksnys yra svarbesnis už antrajji, tuomet naudojamas sveikas skaičius iš skalès (1...9), kitu atveju - atvirkštinis dydis $(1 / 1 \ldots 1 / 9)$. Bet kuriuo atveju, vienas kitam atvirkštiniai reikšmingumai matricoje rašomi simetriškai. Iš viso reikia atlikti $(n(n-1) / 2)$ lyginimų (n-lyginamų veiksnių skaičius).

Atliekant veiksnių lyginimą esminè problema yra matricos suderinamumo užtikrinimas (Podvezko 2009). Matrica $P$ bus laikoma suderinta jeigu iš minimalaus ją sudarančiu veiksnių kiekio bus galima surasti visus kitus veiksnius. Svarbi matricos suderinamumo sąlyga yra matricą sudarančių veiksnių reikšmingumų pereinamumas: jei pirmasis veiksnys yra svarbesnis negu antrasis, kai tuo 
tarpu antrasis yra svarbesnis už trečiaji, tai pirmasis tokiu atveju yra svarbesnis už trečiajji.

Sąlygos, reikalingos, kad matrica būtų suderinta, gali būti išreikštos matematiškai. Tokiu atveju, matrica $P$ yra padauginama iš reikšmingumų stulpelio, t. y. iš transponuotos eilutès $w=\left(w_{1}, w_{2}, \ldots, w_{n}\right)^{T}$ :

$$
P w=\left[\begin{array}{ccc}
\frac{w_{1}}{w_{1}} & \cdots & \frac{w_{1}}{w_{n}} \\
\vdots & \cdots & \vdots \\
\frac{w_{n}}{w_{1}} & \cdots & \frac{w_{n}}{w_{n}}
\end{array}\right]\left[\begin{array}{c}
w_{1} \\
\vdots \\
w_{n}
\end{array}\right]=n\left[\begin{array}{c}
w_{1} \\
\vdots \\
w_{n}
\end{array}\right]=n w .
$$

Gautini reikšmingumai - vektorius $w$ yra tikrinio vektoriaus komponentai normalizuoti atsižvelgiant ị didžiausią matricos $P$ tikrinę reikšmę $\lambda_{\max }$ :

$$
P w=\lambda_{\max } w .
$$

Žinoma (Saaty 1990), kad didžiausia atvirkščiai simetriškos matricos $n$ eilutès tikrinè reikšmé yra $\lambda_{\max } \geq n$. Idealiu atveju, kai matrica yra visiškai suderinta ir stulpelių elementai yra proporcingi $\lambda_{\max }=n$. Kitu atveju, matricos suderinamumas apibūdinamas skirtumu $\lambda_{\max }-n$.

Ekspertų pateikiamų įverčių nepriekaištingumas nustatomas skaičiuojant ekspertų vertinimų suderinamumo indeksą (Saaty 2005, 2008; Podvezko 2007, 2009):

$$
S_{I}=\frac{\lambda_{\max }-n}{n-1}
$$

čia $n$ - veiksnių skaičius.

Padalinus suderinamumo indeksą iš skaičiaus, atitinkančio tos pačios eilès matricos atsitiktinius suderinamumus (2.3 lentelè), gaunamas suderinamumo santykis $S_{S}$, kuris apibrezžia matricos suderinamumą.

2.3 lentelè. Atsitiktinių suderinamumų indeksų reikšmès

Table 2.3. The values of random consistensy indexes

\begin{tabular}{|l|c|c|c|c|c|c|c|c|c|c|}
\hline Matricos dydis & 1 & 2 & 3 & 4 & 5 & 6 & 7 & 8 & 9 & 10 \\
\hline $\begin{array}{l}\text { Atsitiktiniai suderi- } \\
\text { namumai }\left(S_{A}\right)\end{array}$ & 0 & 0 & 0,58 & 0,90 & 1,12 & 1,24 & 1,32 & 1,41 & 1,45 & 1,49 \\
\hline
\end{tabular}

Saltinis: Saaty 2008 
Tenkinant sąlygą $S_{S}<0,1$, skaitoma, kad matrica yra suderinta, kitu atveju nustatomas nesuderinamumas, todèl ekspertams reikia iš naujo peržiūrèti matricą, ịsigilinti ị užduoties sąlygas ir patikrinti savo samprotavimus.

Bendras ekspertų vertinimo suderinamumas nustatomas taikant konkordancijos koeficientą $W$, kuris leidžia įvertinti ekspertų nuomonių sutapimo lygị. Kaip jau minèta, siekiant apskaičiuoti konkordancijos koeficientą, pirmiausia reikia preliminariai suranguoti veiksnius svarbumo atžvilgiu. Surangavus veiksnius, konkordancijos koeficientas apskaičiuojamas pagal formulę (Podvezko 2005):

$$
W=\frac{12 S}{r^{2} n\left(n^{2}-1\right)},
$$

čia $r$ - ekspertų skaičius, $n$ - vertinamų veiksnių skaičius, $S$ - veiksnių rangų sumų nuokrypių nuo bendro vidurkio kvadratų suma, skaičiuojama pagal formulę:

$$
S=\sum_{j=1}^{n}\left(r \times j-\frac{1}{2} r(n+1)\right)^{2}
$$

Jeigu konkordancijos koeficiento reikšmè yra arti vieneto, tai rodo, kad ekspertų vertinimai neprieštaringi.

Konkordancijos koeficientas gali būti taikomas tik tada kai nustatyta jo ribinè reikšmé, rodanti kada ekspertų vertinimus dar galima laikyti suderintais. M. Kendall (1970) įrodè, kad jeigu objektų skaičius $n>7$ konkordancijos koeficiento reikšmingumas gali būti nustatytas naudojant $\chi^{2}$ kriterijų, kuris skaičiuojamas pagal formulę (Podvezko 2005, 2006):

$$
x^{2}=W r(n-1)=\frac{12 S}{r n(n+1)} .
$$

Kai suskaičiuota $\chi^{2}$ reikšmė didesnè už kritinę $\chi_{k r}{ }^{2}$ iš $\chi^{2}$ skirstinio lentelès su $v=n-1$ laisvès laipsniu ir pasirinktu reikšmingumo lygmeniu $\alpha$, artimu nuliui, tai reiškia, kad ekspertų vertinimai yra suderinti ir veiksnių reikšmingumus galima taikyti tolimesniems skaičiavimams. Kai lyginamų veiksnių skaičius $n$ yra nuo trijų iki septynių, $\chi^{2}$ skirstinį reikia taikyti atsargiai, nes skirstinio kritine $\chi_{k r}^{2}$ reikšmė gali būti didesnè už suskaičiuotą, nors ekspertų nuomonių suderinamumo lygis dar pakankamas. Tokiu atveju galima taikyti konkordancijos koeficiento tikimybines lenteles arba kritinių reikšmių $S$ lenteles (Podvezko 2005). 
Konkordancijos koeficientas pagal 2.10 formulę skaičiuojamas kai nėra sutampančių rangų, tačiau praktikoje būna atvejų, kai du arba keletas objektų yra labai panašūs ir neịmanoma vienam iš jų suteikti pirmenybès. Esant labai tarpusavyje susijusiems objektams priskiriamas vienodas rangas - eilinių rangų aritmetinis vidurkis. Tokiu atveju konkordancijos koeficientas skaičiuojamas pagal formulę:

$$
W=\frac{12 S}{r^{2} n\left(n^{2}-1\right)-r \sum_{j=1}^{r} T_{j}} .
$$

čia $T_{j}-j$-ojo eksperto susietų rangų rodiklis, kuris skaičiuojamas pagal formulę:

$$
T_{j}=\sum_{i=1}^{H_{j}}\left(t_{i}^{3}-t_{i}\right)
$$

čia $H_{j}$ - lygių rangų $j$-ojo eksperto skaičius; $t_{i}$ - lygių susietų rangų $i$-tasis grupès skaičius.

Atitinkamai $\chi^{2}$ skaičiuojama taip:

$$
x^{2}=W r(m-1)=\frac{12 S}{r m(m+1)-\frac{1}{m-1} \sum_{j=1}^{r} T_{j}} .
$$

\section{4. Šalies konkurencingumą lemiančių veiksnių būklès pokyčių dẻl investuotụ finansinių išteklių nustatymas}

Siekiant išspręsti šalies konkurencingumo pokyčio optimizavimo uždavinį, svarbu žinoti kokị poveikị finansiniai ištekliai turi šalies konkurencingumą lemiantiems veiksniams, kitaip - koks bus šalies konkurencingumą lemiančių veiksnių pokytis dèl i juos investuotos tam tikros finansinių išteklių sumos. Atsižvelgiant ị tai, kad darbe suformuotas originalus šalies konkurencingumą lemiančių veiksnių rinkinys, statistikos apie tai kokią naudą generuoja ị kiekvieną jų investuojami finansiniai ištekliai nèra. Dèl galimybès kiekybiškai įvertinti šalies konkurencingumą lemiančių veiksnių būklès pokyčius dèl ị juos investuotų finansinių išteklių nebuvimo, siūloma taikyti ekspertinio vertinimo metodą.

Atliekant ekspertinį vertinimą susiduriama su neapibrèžtumo problema, nes šalies konkurencingumą lemiančių veiksnių būklès pokyčiai dèl investuotų fi- 
nansinių išteklių turi savybę igauti iš anksto vienareikšmiškai nenusakomas ir nuo atsitiktinių priežasčių priklausomas reikšmes. Todèl, kad ir kokie savo srities žinovai būtų vertinime dalyvausiantys ekspertai, konkrečiai, vienareikšmiškai ir užtikrintai pateikti vertinamo objekto iverčių jie negalès. Atsižvelgiant ị tai, priimamas sprendimas taikyti A. V. Rutkausko (2012) pasiūlytą ir atliekant tyrimus (Ruškytè et al. 2013) taikomą stochastiškai informatyvią ekspertizę. Taikant ši ekspertinio vertinimo modelį šalies konkurencingumą lemiančių veiksnių būklès pokyčių dèl investuotų finansinių išteklių ekspertiniai ịverčiai nusakomi galimybių tikimybių skirstinius apibūdinančiomis skaitinèmis charakteristikomis.

Atliekant vertinimą, ekspertai nurodo numanomą kiekvieno šalies konkurencingumą lemiančio veiksnio būklès pagerejjimą (pokytị) procentais dèl i ji investuotos tam tikros finansinių išteklių sumos, kuri skaičiavimuose prilyginama vienam piniginiam vienetui. Šalies konkurencingumą lemiančio veiksnio būklès pokytis dèl $\mathrm{i}$ jị investuoto vieno piniginio vieneto žymimas $s_{j}$ (2.4 lentelè).

2.4 lentelè. Veiksnių pokyčių ekspertinis vertinimas

Table 2.4. The expert evaluation of factors' changes

\begin{tabular}{|c|c|c|c|c|c|}
\hline \multirow{2}{*}{\multicolumn{2}{|c|}{$\begin{array}{l}\text { Šalies konkurencingumą } \\
\text { lemiantys veiksniai }\end{array}$}} & \multicolumn{4}{|c|}{ Veiksnių pokyčių įverčiai } \\
\hline & & 1 eksp. & 2 eksp. & $\ldots$ & $r$ eksp. \\
\hline Institucinė aplinka & $V_{1}$ & $s_{l, 1}$ & $s_{2,1}$ & $s_{i, 1}$ & $s_{r, 1}$ \\
\hline Inžinerinė infrastruktūra & $V_{2}$ & $s_{1,2}$ & $s_{2,2}$ & $s_{i, 2}$ & $s_{r, 2}$ \\
\hline Technologinė infrastruktūra & $V_{3}$ & $\ldots$ & $\ldots$ & $\ldots$ & $\ldots$ \\
\hline Mokslinė infrastruktūra & $V_{4}$ & $\ldots$ & $\ldots$ & $\ldots$ & $\ldots$ \\
\hline Švietimas & $V_{5}$ & $s_{l, j}$ & $s_{2, j}$ & $s_{i, j}$ & $\ldots$ \\
\hline Socialinė aplinka & $V_{6}$ & $\ldots$ & $\ldots$ & $\ldots$ & $\ldots$ \\
\hline Produktų rinka & $V_{7}$ & $\ldots$ & $\ldots$ & $\ldots$ & $\ldots$ \\
\hline Darbo rinka & $V_{8}$ & $\ldots$ & $\ldots$ & $\ldots$ & $\ldots$ \\
\hline Finansų rinka & $V_{9}$ & $\ldots$ & $\ldots$ & $\ldots$ & $\ldots$ \\
\hline Verslo pažanga & $V_{10}$ & $s_{1,10}$ & $s_{2,10}$ & $s_{i, 10}$ & $s_{r, 10}$ \\
\hline
\end{tabular}

Šaltinis: sudaryta autorès

Remiantis tikimybių teorija, daroma prielaida, kad atsitiktiniai dydžiai $s_{j}$ yra pasiskirstę pagal normaluji dèsni. Tokiu atveju dydžių $s_{j}$ skaitinès charakteristikos nustatomos pagal tokias formules:

$$
\begin{gathered}
E s_{j}=\frac{1}{r} \sum_{i=1}^{r} s_{i j} ; \\
D s_{j}=\frac{1}{r} \sum_{i=1}^{r} s_{i j}{ }^{2}-\left(E s_{j}\right)^{2} ;
\end{gathered}
$$




$$
\sigma \boldsymbol{s}_{j}=\sqrt{D s_{j}}
$$

čia $E s_{j}-r$ ekspertų pateiktų veiksnių pokyčiu ịverčių rinkinio vidurkis; $D s_{j}-$ dydžio $s_{j}$ dispersija; $\sigma s_{j}-$ dydžio $s_{j}$ standartinis nuokrypis.

\section{5. Šalies konkurencingumo pokyčio optimizavimo modelis}

Ivvertinus šaliu patirties analizès (1.2 skyrius) metu atskleistą būtinybę sukurti tvirtą pagrindą šalies konkurencingumo skatinimo sprendimų priemimui, kaip vieną iš priemonių priimant sprendimus siūloma naudoti finansinių išteklių tarp konkurencingumą lemiančių veiksnių paskirstymo planą, gautiną išsprendus šalies konkurencingumo pokyčio optimizavimo uždavinį.

Atsižvelgiant i tai, kad šalies konkurencingumo pokyčio optimizavimo uždavinio vieni iš parametrų $\left(s_{j}\right)$ yra atsitiktiniai dydžiai, sprendžiamas stochastinio programavimo uždavinys. Uždavinio sprendimui sudaromas toks šalies konkurencingumo pokyčio optimizavimo modelis:

$$
\begin{gathered}
P\left(\max \sum_{j=1}^{n} w_{j} s_{j} x_{j} \geq \Delta K\right) \geq 1-\alpha ; \\
\sum_{j=1}^{n} x_{j} \leq c ; \\
x_{j} \geq 0, j=1, \ldots, n,
\end{gathered}
$$

čia $w_{j}-j$-ojo veiksnio reikšmingumas; $s_{j}$ - atsitiktinis dydis, nusakantis $j$-ojo veiksnio pokyti; $x_{j}$ - finansinių išteklių suma skiriama $j$-ajam veiksniui (uždavinio nežinomasis); $n$ - veiksnių skaičius; $c$ - šalies konkurencingumo skatinimui skirtų finansinių išteklių suma; $1-\alpha-$ pasikliovimo lygmuo (tikimybė); uždavinio nežinomasis $\Delta K$ - šalies konkurencingumo pokyčio $\sum_{j=1}^{n} w_{j} s_{j} x_{j}$ apatinė riba.

Nustatant uždavinio apribojimus, priimama, kad bendra visiems veiksniams tenkanti finansinių išteklių suma negali viršyti šalies konkurencingumo skatinimui skiriamos $\operatorname{sumos} c$. Taip pat, $j$-ajam veiksniui tenkančių finansinių išteklių suma $x_{j}$ negali būti neigiama.

Sprendžiant optimizavimo uždavini pagal ši modelị (2.19-2.21) ieškomas toks nežinomujų vektorius $X=\left(x_{1}, x_{2}, \ldots, x_{10}\right)$, kuriam esant šalies konku- 
rencingumo pokytis $\sum_{j=1}^{n} w_{j} s_{j} x_{j}$ su tam tikru pasikliovimo lygmeniu $1-\alpha$ igis didžiausią reikšmę, t. y. bus optimalus. Kitaip tariant, išsprendus uždavinį gautinas optimalaus šalies konkurencingumo skatinimui skirtų finansinių išteklių paskirstymo planas, pagal kurị, esant tam tikrai tikimybei, šalies konkurencingumo pokytis bus optimalus.

Ekvivalentiškas (2.19-2.21) stochastinio programavimo uždavinio modeliui yra toks modelis:

$$
\begin{gathered}
\max \Delta K ; \\
P\left(\sum_{j=1}^{n} w_{j} s_{j} x_{j} \geq \Delta K\right) \geq 1-\alpha ; \\
\sum_{j=1}^{n} x_{j} \leq c ; \\
x_{j} \geq 0, j=1, \ldots, n .
\end{gathered}
$$

Pagal priimtą prielaidą, atsitiktiniai dydžiai $s_{j}$ yra pasiskirstę pagal normalųji dèsni $-s_{j} \sim N\left(E s_{j}, \sigma s_{j}\right)$. Tuomet $j$-tasis demuo $w_{j} s_{j} x_{j}$ taip pat yra pasiskirstęs pagal normalujji désni su vidurkiu $w_{j} E s_{j} x_{j}$ ir nuokrypiu $w_{j} \sigma s_{j} x_{j}$. Sumos $\sum_{j=1}^{n} w_{j} s_{j} x_{j}$ skirstinys bus normalusis su vidurkiu $\sum_{j=1}^{n} w_{j} E s_{j} x_{j}$ ir nuokrypiu $\sqrt{\sum_{j=1}^{n} w_{j}^{2} D s_{j} x_{j}^{2}}$. Tuomet:

$$
\sum_{j=1}^{n} w_{j} s_{j} x_{j} \in N\left(\sum_{j=1}^{n} w_{j} E s_{j} x_{j}, \sqrt{\sum_{j=1}^{n} w_{j}^{2} D s_{j} x_{j}^{2}}\right) .
$$

Siekiant pagal anksčiau sudarytą modelị (2.19-2.21) išspręsti optimizavimo uždavini su bet kokia optimizavimo uždaviniams spręsti skirta programa, turi būti sudaromas netiesinio programavimo uždavinio modelis.

Iš nelygybių

$$
\begin{gathered}
P\left(\sum_{j=1}^{n} w_{j} s_{j} x_{j} \geq \Delta K\right) \geq 1-\alpha ; \\
P\left(\Delta K \leq \sum_{j=1}^{n} w_{j} s_{j} x_{j} \leq+\infty\right) \geq 1-\alpha,
\end{gathered}
$$


ivvedus papildomą kintamąji

$$
\begin{gathered}
z=\sqrt{\left.\sum_{j=1}^{n} w_{j}{ }^{2} D s_{j} x_{j}{ }^{2}\right)} ; \\
z^{2}=\sum_{j=1}^{n} w_{j}{ }^{2} D s_{j} x_{j}{ }^{2} .
\end{gathered}
$$

gaunamas toks netiesinio programavimo uždavinio modelis:

$$
\begin{gathered}
\max \Delta K ; \\
\sum_{j=1}^{n} w_{j} E s_{j} x_{j}-u_{\alpha} z \geq \Delta K ; \\
z^{2}-\sum_{j=1}^{n} w_{j}{ }^{2} D s_{j} x_{j}{ }^{2}=0 ; \\
\sum_{j=1}^{n} x_{j} \leq c ; \\
x_{j} \geq 0, j=1, \ldots, n ; \\
z \geq 0,
\end{gathered}
$$

čia $E s_{j}$ - atsitiktinio dydžio $s_{j}$ vidurkis; $u_{\alpha}$ - normaliojo skirstinio kritinè reikšmè lygmens $\alpha ; z$ - papildomas kintamasis; $D s_{j}-$ atsitiktinio dydžio $s_{j}$ dispersija.

\subsection{Antrojo skyriaus išvados}

1. Ieškant šalies konkurencingumo skatinimo sprendimų pagrịstumo didinimo galimybių, pasiūlyta koncepcija, pagal kurią šalies konkurencingumo skatinimo sprendimų prièmimo procesas suvokiamas kaip šalies konkurencingumo skatinimui skirtų finansinių išteklių nukreipimas ị konkurencingumą lemiančius veiksnius, tikintis jų būklès pagerèjimo ir šalies konkurencingumo didejjimo. Remiantis tokiu požiūriu, svarbiausiu uždaviniu laikytinas efektyvus šalies konkurencingumui skirtu finansinių išteklių paskirstymas. Todèl be konkurencingumo vertinimo, kuris daugelyje šalių sudaro priimamų sprendimų pagrindą, tikslinga atsižvelgti ir ị optimalaus finansinių išteklių paskirstymo tarp šalie konkurencingumą lemiančių veiksnių planą.

2. Šalies konkurencingumo vertinimui siūlomo metodo pagrindas - remiantis praktikoje taikomų veiksnių rinkinių ir mokslinès literatūros analize, su- 
darytas ir, atsižvelgiant i pasiūlytą šalies konkurencingumo sprendimų prièmimo koncepciją, patikslintas veiksnių rinkinys. Rinkinį sudarančių veiksnių turinys detalizuotas iki dalinių veiksnių, kurių reikšmėms apskaičiuoti, remiantis Lietuvos pavyzdžiu, pasiūlytas rodiklių rinkinys. Šalies konkurencingumo (veiksnių) būklès vertinimas atliekamas apskaičiuojant veiksnių ir bendro konkurencingumo integruotus kompleksinius rodiklius.

3. Siekiant galimai tiksliau ịvertinti konkurencingumą ir sudaryti realias sąlygas išspręsti šalies konkurencingumo pokyčio optimizavimo uždavinį, tikslinga kiekvienam šalies konkurencingumą lemiančiam veiksniui ir juos sudarantiems daliniams veiksniams nustatyti skirtingą svarbą atskleidžiančius reikšmingumus. Reikšmingumų nustatymui siūloma taikyti analitinès hierarchijos proceso metodą.

4. Šalies konkurencingumo veiksnių būklès pokyčių dèl investuotų finansinių išteklių nustatymui siūlomas taikyti ekspertinio vertinimo metodas. Gautini ekspertų ịverčiai, remiantis tikimybių teorija, laikomi atsitiktiniais dydžiais, pasiskirsčiusiais pagal normalujji dèsni ir nusakomi galimybių tikimybių skirstinius apibūdinančiomis skaitinėmis charakteristikomis - vidurkiu, standartiniu nuokrypiu, dispersija.

5. Šalies konkurencingumo sprendimų prièmime siūlomas naudoti optimalaus šalies konkurencingumui skirtų finansinių išteklių paskirstymo planas, gautinas išsprendus šalies konkurencingumo pokyčio optimizavimo uždavinị. Atsižvelgiant ị tai, kad vieni iš uždavinio parametrų - veiksnių pokyčiai yra atsitiktiniai dydžiai turi būti sprendžiamas stochastinis programavimo uždavinys. Uždavinio sprendimui sudarytas šalies konkurencingumo pokyčio optimizavimo modelis. 



\section{Lietuvos konkurencingumo vertinimo ir pokyčio optimizavimo empiriniai tyrimai}

Siekiant patikrinti darbe pasiūlytų šalies konkurencingumo vertinimo metodo ir šalies konkurencingumo pokyčio optimizavimo modelio, sudarytu siekiant padidinti priimamų sprendimų pagrisstumą, praktinị priimtinumą, atliekami empiriniai tyrimai Lietuvos atveju. Siame skyriuje pristatomi ir aptariami empiriniu tyrimų eiga bei rezultatai. Tyrimų rezultatai publikuoti moksliniame žurnale (Rakauskienè, Tamošiūnienè 2013).

\subsection{Empirinių tyrimų eiga ir rezultatai}

Darbe pasiūlyto konkurencingumo vertinimo metodo ir sudaryto šalies konkurencingumo pokyčio optimizavimo modelio praktinis priimtinumas tikrinamas atliekant empirinius tyrimus Lietuvos atveju. 
Lietuvos konkurencingumo vertinimas. Lietuvos konkurencingumo (veiksnių) būklès vertinimui priimamas darbe pasiūlytas šalies konkurencingumą lemiančių veiksnių turinị apibūdinančių dalinių veiksnių rinkinys (2.1 lentelè).

Vertinimas atliekamas vadovaujantis tokia veiksmų seka:

1. Nustatomos Lietuvos konkurencingumo veiksnius sudarančių dalinių veiksnių $v_{j i}$ reikšmès.

2. Nustatomi dalinių veiksnių ir veiksnių santykiniai reikšmingumai $w_{j i}, w_{j}$.

3. Apskaičiuojamos Lietuvos konkurencingumo veiksnių $V_{j}$ ir bendro konkurencingumo $K$ reikšmès.

Siekiant nustatyti dalinių veiksnių reikšmes atliekama statistinių duomenų analizè - kiekybinių rodikliu reikšmėms nustatyti ir ekspertinis vertinimas kokybinių rodiklių reikšmèms nustatyti.

Ekspertiniame vertinime, kuris atliktas 2013 m. kovo-gegužès mèn., iš viso dalyvavo 6 ekspertai. Trys ekspertai užima aukštas pareigas valstybės tarnyboje ir yra glaudžiai susiję su aukščiausio lygio strateginių sprendimų prièmimu. Du ekspertai vykdo mokslinius tyrimus tokiose moksliniu interesų srityse kaip ūkio ekonominis efektyvumas, ūkio plètra ir funkcionavimo patikimumas, finansu prognozavimas ir valdymas ir kt. Dar vienas ekspertas specializuojasi projektu rengimo ir igyvendinimo bei strateginio planavimo srityse. Ekspertai tyrimui pasirinkti atsižvelgiant ị aukštą jų kompetenciją ir žinių, susijusių su tyrimų objektu lygi.

Prieš atliekant tyrimą ekspertai individualiai buvo supažindinti su atliekamo tyrimo tikslu ir vertinimo metodika. Ekspertams buvo pateikta užduotis kiekvienam tam tikrą Lietuvos konkurencingumo dalinį veiksnį apibūdinančiam aspektui (kokybiniam rodikliui) suteikti reikšmes intervale [0, 1], kai 1 - geriausias ịvertinimas, o 0 - blogiausias. Vertinimo metu ekspertai galèjo bendrauti su tyrimo iniciatore, tačiau vertinti turèjo individualiai, savo įverčius nurodydami tam tikslui sudarytoje anketoje. Tyrimo metu gautos ekspertu konkrečių kokybinių rodiklių reikšmès sudedamos ir apskaičiuojamas aritmetinis vidurkis, kuris, kaip kokybinio rodiklio ịvertis, naudojamas tolimesniuose skaičiavimuose (B priedas).

Daliniu veiksnių reikšmių nustatymui reikalingi kiekybiniai rodikliai gauti atliekant statistinių duomenų analizę. Statistiniai duomenys, siekiant juos padaryti tinkamais tolimesniems skaičiavimams, normalizuoti, kad igautų reikšmes intervale $[0,1]$. I bemati pavidalą rodikliai, išreikšti įvairiais matavimo vienetais perskaičiuoti naudojantis 2.1 ir 2.2 formulemis (B priedas). Siekiant nustatyti maksimalias ir minimalias rodiklių reikšmes, priimta šalių grupe, kurią sudaro 28 oficialios Europos Sajungos valstybès narès, šalys kandidatès Makedonija, Islandija, Juodkalnija, Serbija ir Turkija bei Europos Sajungai nepriklausančios - Norvegija ir Šveicarija. 
Lietuvos konkurencingumą lemiančių veiksnių reikšmių skaičiavimui naudotinos dalinių veiksnių reikšmès pateiktos 3.1 lentelèje.

3.1 lentelè. Dalinių veiksnių $v_{j i}$ reikšmès, balai

Table 3.1. Values of sub-factors $v_{j i}$, scores

\begin{tabular}{|c|c|c|}
\hline \multicolumn{2}{|l|}{ Daliniai veiksniai } & Reikšmės \\
\hline Teisės viršenybė & $v_{11}$ & 0,73 \\
\hline Korupcijos mastas & $v_{12}$ & 0,66 \\
\hline Reguliavimo kokybė & $v_{13}$ & 0,79 \\
\hline Valdžios veiksmingumas & $v_{14}$ & 0,72 \\
\hline Kelių tinklo infrastruktūra & $v_{21}$ & 0,13 \\
\hline Geležinkelių infrastruktūra & $v_{22}$ & 0,22 \\
\hline Oro transporto infrastruktūra & $v_{23}$ & 0,04 \\
\hline Vandens transporto infrastruktūra & $v_{24}$ & 0,33 \\
\hline Energijos perdavimo infrastruktūra & $v_{25}$ & 0,80 \\
\hline Fiksuoto telefono ryšio prieinamumas & $v_{31}$ & 0,05 \\
\hline Judriojo telefono ryšio paplitimas & $v_{32}$ & 0,58 \\
\hline Interneto naudojimas & $v_{33}$ & 0,29 \\
\hline Plačiajuosčio ryšio prieinamumas & $v_{34}$ & 0,24 \\
\hline Naujausiu technologijų prieinamumas & $v_{35}$ & 0,62 \\
\hline Naujausiu technologiju diegimas & $v_{36}$ & 0,47 \\
\hline Inovacijų kūrimo pajègumai & $v_{41}$ & 0,52 \\
\hline Mokslinių tyrimų institucijų kokybė & $v_{42}$ & 0,5 \\
\hline Universitetų ir verslo bendradarbiavimas & $v_{43}$ & 0,53 \\
\hline Išradimų patentai & $v_{44}$ & 0,01 \\
\hline Žmogiškieji ištekliai mokslinèje veikloje & $v_{45}$ & 0,35 \\
\hline Pradinis ugdymas & $v_{51}$ & 0,43 \\
\hline Aukštesnis mokymas & $v_{52}$ & 0,52 \\
\hline Aukštasis mokslas & $v_{53}$ & 0,66 \\
\hline Darbuotojų mokymai & $v_{54}$ & 0,50 \\
\hline Gyvenimo trukmè & $v_{61}$ & 0,21 \\
\hline Kūdikių mirtingumas & $v_{62}$ & 0,72 \\
\hline Ligų paplitimas & $v_{63}$ & 0,72 \\
\hline Sveikatos priežiūra & $v_{64}$ & 0,67 \\
\hline Skurdas ir socialinè atskirtis & $v_{65}$ & 0,52 \\
\hline Oro kokybė & $v_{66}$ & 0,77 \\
\hline Atlieku perdirbimas & $v_{67}$ & 0,50 \\
\hline Atsinaujinančioji energija & $v_{68}$ & 0,26 \\
\hline Verslo pradžios procedūros & $v_{71}$ & 0,45 \\
\hline Mokesčiu mokèjimai & $v_{72}$ & 0,68 \\
\hline Prekybos laisvė & $v_{73}$ & 0,87 \\
\hline Investavimo laisvė & $v_{74}$ & 0,80 \\
\hline Darbo jègos laisvè & $v_{81}$ & 0,64 \\
\hline
\end{tabular}


3.1 lentelès pabaiga

\begin{tabular}{|l|c|c|}
\hline \multicolumn{2}{|l|}{ Daliniai veiksniai } & Reikšmės \\
\hline Darbdavių ir darbuotojų santykiai & $v_{82}$ & 0,55 \\
\hline Užmokestis ir našumas & $v_{83}$ & 0,57 \\
\hline Protų nutekejjimas & $v_{84}$ & 0,40 \\
\hline Moterys darbo rinkoje & $v_{85}$ & 0,96 \\
\hline Finansinių paslaugų prieinamumas & $v_{91}$ & 0,57 \\
\hline Vertybinių popierių rinkos veikla & $v_{92}$ & 0,38 \\
\hline Finansų rinkos patikimumas & $v_{93}$ & 0,54 \\
\hline Finansų valdymas & $v_{94}$ & 0,34 \\
\hline Klasterių plètra & $v_{101}$ & 0,30 \\
\hline İmonių atskaitomybė & $v_{102}$ & 0,63 \\
\hline Imonių valdymas & $v_{103}$ & 0,55 \\
\hline Verslo kultūra & $v_{104}$ & 0,54 \\
\hline Strategija ir operacijos. & $v_{105}$ & 0,54 \\
\hline
\end{tabular}

Šaltinis: sudaryta autorès

Toliau, vadovaujantis 2.3 paveiksle pateikta schema, atliekamas Lietuvos konkurencingumą lemiančių veiksnių ir juos apibūdinančių dalinių veiksnių santykinių reikšmingumų nustatymas. Sudaryta ekspertinio vertinimo anketa pateikiama anksčiau ịvardintiems ekspertams prašant jas užpildyti naudojantis 9 balų santykinių įverčių skale (2.2 lentelè).

Gauti ekspertinio vertinimo rezultatai toliau perskaičiuojami i santykinius reikšmingumus tokiu veiksmų eiliškumu (pavyzdys pateiktas priede C):

1. Sudauginami eilutès įverčiai.

2. Iš gautos sandaugos reikšmès ištraukiama $n$ laipsnių ( $n$ - veiksnių skaičius) šaknis - gaunamas prioritetinis vektorius.

3. Gauta prioritetinio vektoriaus reikšmè normalizuojama, t. y. padalinama iš bendros sumos - gaunamas santykinis reikšmingumas $w$.

4. Eiluteje pateikti veiksnių ivverčiai dauginami iš reikšmingumų $w$ stulpelio (2.7 formulè).

5. Gauta reikšmè $P w$ dalinama iš santykinio reikšmingumo $w$ - gaunama tikrinè reikšmè $\lambda_{\max }$.

6. $\lambda_{\max }$ reikšmès sudedamos ir padalinus iš $n$ ( $n$ - veiksnių skaičius) nustatoma vidutinè $\lambda_{\max }$ reikšmè.

Nustačius didžiausią matricos tikrinę reikšmę $\lambda_{\max }$ toliau, siekiant nustatyti ar gauti rezultatai yra tinkami tolimesniems skaičiavimams, t. y. ar ekspertu vertinimai yra nepriekaištingi, pagal 2.9 formulę skaičiuojamas suderinamumo indeksas $S_{I}$ ir, naudojantis 2.3 lenteleje pateiktomis atsitiktinio suderinamumo reikšmèmis, suderinamumo santykis $S_{S}$.

Dèl nepriimtino rezultatu suderinamumo pakartotinai vertinimą turejo atlikti 4 ekspertai. Su ekspertais iš naujo buvo aptarta situacija ir paprašyta pakar- 
totinai ịvertinti veiksnių reikšmingumą. Siekiant, kad pakartotinis vertinimas būtų sèkmingas, ekspertams buvo pateikta daugiau informacijos apie veiksnius, lemiančius Lietuvos konkurencingumą. Pakartotinio vertinimo matricos tenkino $S_{I} \leq 0,1$ sąlygą (3.2 lentelè).

3.2 lentelè. Suderinamumo indekso $S_{I}$ ir santykio $S_{S}$ reikšmès

Table 3.2. The values of consistency index $S_{I}$ and ratio $S_{S}$

\begin{tabular}{|c|c|c|c|c|c|c|c|}
\hline \multirow{2}{*}{ Veiksniai } & \multirow{2}{*}{ Reikšmės } & \multicolumn{7}{|c|}{ Ekspertai } \\
\cline { 2 - 7 } & & 1 & 2 & 3 & 4 & 5 & 6 \\
\hline \multirow{2}{*}{$V_{1}$} & $S_{I}$ & 0,051 & 0,039 & 0,082 & 0,020 & 0,000 & 0,028 \\
\cline { 2 - 7 } & $S_{S}$ & 0,057 & 0,043 & 0,091 & 0,022 & 0,000 & 0,030 \\
\hline \multirow{2}{*}{$V_{2}$} & $S_{I}$ & 0,051 & 0,049 & 0,036 & 0,095 & 0,054 & 0,037 \\
\cline { 2 - 7 } & $S_{S}$ & 0,046 & 0,044 & 0,032 & 0,085 & 0,048 & 0,033 \\
\hline \multirow{2}{*}{$V_{4}$} & $S_{I}$ & 0,013 & 0,028 & 0,045 & 0,068 & 0,041 & 0,067 \\
\cline { 2 - 7 } & $S_{S}$ & 0,011 & 0,022 & 0,036 & 0,055 & 0,033 & 0,054 \\
\hline \multirow{2}{*}{$V_{5}$} & $S_{I}$ & 0,061 & 0,037 & 0,047 & 0,054 & 0,037 & 0,037 \\
\cline { 2 - 7 } & $S_{S}$ & 0,054 & 0,033 & 0,042 & 0,048 & 0,033 & 0,033 \\
\hline \multirow{2}{*}{$V_{6}$} & $S_{I}$ & 0,011 & 0,051 & 0,015 & 0,003 & 0,011 & 0,051 \\
\hline \multirow{2}{*}{$V_{7}$} & $S_{S}$ & 0,012 & 0,057 & 0,017 & 0,004 & 0,012 & 0,057 \\
\cline { 2 - 7 } & $S_{I}$ & 0,031 & 0,007 & 0,099 & 0,009 & 0,000 & 0,061 \\
\hline \multirow{2}{*}{$V_{8}$} & $S_{I}$ & 0,022 & 0,005 & 0,070 & 0,007 & 0,000 & 0,044 \\
\cline { 2 - 7 } & $S_{S}$ & 0,057 & 0,051 & 0,078 & 0,027 & 0,051 & 0,051 \\
\hline \multirow{2}{*}{$V_{9}$} & $S_{I}$ & 0,037 & 0,089 & 0,087 & 0,030 & 0,057 & 0,057 \\
\cline { 2 - 7 } & $S_{S}$ & 0,033 & 0,079 & 0,030 & 0,016 & 0,061 & 0,017 \\
\cline { 2 - 7 } & $S_{I}$ & 0,038 & 0,014 & 0,051 & 0,001 & 0,051 & 0,062 \\
\hline \multirow{2}{*}{$V_{10}$} & $S_{S}$ & 0,042 & 0,016 & 0,057 & 0,002 & 0,057 & 0,069 \\
\cline { 2 - 7 } & $S_{I}$ & 0,037 & 0,082 & 0,073 & 0,014 & 0,085 & 0,037 \\
\hline & $S_{S}$ & 0,033 & 0,073 & 0,065 & 0,012 & 0,076 & 0,033 \\
\hline
\end{tabular}

Saltinis: sudaryta autorès

Toliau, siekiant nustatyti bendrą ekspertų vertinimo suderinamumą, skaičiuojami konkordancijos koeficientai. Norint apskaičiuoti šiuos koeficientus, pirmiausia nustatomi dalinių veiksnių rangai (3.3 lentelè).

Atsižvelgiant ị tai, kad yra pasikartojančių rangų, konkordancijos koeficientai skaičiuojami pagal 2.13 formulę. Konkordancijos koeficientų skaičiavimui reikalingos veiksnių rangų sumų nuokrypių nuo bendro vidurkio kvadratu sumos $S$ apskaičiuotos pagal 2.11 formulę. Siekiant įsitikinti konkordancijos koeficientų reikšmių reikšmingumu, remiantis 2.15 formule, skaičiuojami $\chi^{2}$ kriterijai, kurių reikšmės lyginamos su $\chi^{2}$ skirstinio kritinėmis reikšmėmis $\chi_{k r}$, 
parinktomis atsižvelgiant ị laisvès laipsnių skaičių bei priimamą reikšmingumo lygi - 0,01 (3.4 lentelè).

3.3 lentelè. Dalinių veiksnių reikšmingumų rangai

Table 3.3. The ranks of significances of sub-factors

\begin{tabular}{|c|c|c|c|c|c|c|c|c|}
\hline \multirow{2}{*}{ Veiksniai } & \multirow{2}{*}{$\begin{array}{c}\text { Daliniai } \\
\text { veiksniai }\end{array}$} & \multicolumn{6}{|c|}{ Ekspertai } & \multirow{2}{*}{$\begin{array}{l}\text { Rangų } \\
\text { suma }\end{array}$} \\
\hline & & 1 & 2 & 3 & 4 & 5 & 6 & \\
\hline \multirow{4}{*}{$V_{1}$} & $v_{11}$ & 1,5 & 1 & 1,5 & 2 & 2 & 1,5 & 9,5 \\
\hline & $v_{12}$ & 1,5 & 2 & 1,5 & 1 & 2 & 1,5 & 9,5 \\
\hline & $v_{13}$ & 3 & 3 & 3,5 & 3,5 & 2 & 3 & 18 \\
\hline & $v_{14}$ & 4 & 4 & 3,5 & 3,5 & 4 & 4 & 23 \\
\hline \multirow{5}{*}{$V_{2}$} & $v_{21}$ & 1,5 & 2 & 2 & 1 & 2 & 2 & 10,5 \\
\hline & $v_{22}$ & 3 & 3,5 & 3 & 3 & 4 & 4 & 20,5 \\
\hline & $v_{23}$ & 4 & 3,5 & 4 & 4 & 3 & 4 & 26,5 \\
\hline & $v_{24}$ & 5 & 5 & 5 & 5 & 5 & 4 & 29 \\
\hline & $v_{25}$ & 1,5 & 1 & 1 & 2 & 1 & 1 & 7,5 \\
\hline \multirow{6}{*}{$V_{3}$} & $v_{31}$ & 6 & 5 & 6 & 6 & 6 & 6 & 35 \\
\hline & $v_{32}$ & 2,5 & 1 & 4 & 2 & 3,5 & 4 & 17 \\
\hline & $v_{33}$ & 2,5 & 3 & 3 & 4 & 3,5 & 3 & 19 \\
\hline & $v_{34}$ & 5 & 6 & 5 & 5 & 5 & 5 & 31 \\
\hline & $v_{35}$ & 2,5 & 3 & 2 & 2 & 1,5 & 1,5 & 12,5 \\
\hline & $v_{36}$ & 2,5 & 3 & 1 & 2 & 1,5 & 1,5 & 11,5 \\
\hline \multirow{5}{*}{$V_{4}$} & $v_{41}$ & 1,5 & 2 & 1 & 1 & 1,5 & 1,5 & 8,5 \\
\hline & $v_{42}$ & 1,5 & 2 & 2 & 3 & 1,5 & 1,5 & 11,5 \\
\hline & $v_{43}$ & 3 & 2 & 3 & 4 & 4 & 4 & 20 \\
\hline & $v_{44}$ & 5 & 5 & 5 & 5 & 5 & 5 & 30 \\
\hline & $v_{45}$ & 4 & 4 & 4 & 2 & 3 & 3 & 24 \\
\hline \multirow{4}{*}{$V_{5}$} & $v_{51}$ & 4 & 4 & 4 & 4 & 4 & 4 & 24 \\
\hline & $v_{52}$ & 3 & 1,5 & 3 & 3 & 3 & 2,5 & 16 \\
\hline & $v_{53}$ & 1,5 & 1,5 & 2 & 1,5 & 1,5 & 2,5 & 10,5 \\
\hline & $v_{54}$ & 1,5 & 3 & 1 & 1,5 & 1,5 & 1 & 9,5 \\
\hline \multirow{8}{*}{$V_{6}$} & $v_{61}$ & 1,5 & 3 & 5 & 4 & 4,5 & 3 & 21 \\
\hline & $v_{62}$ & 5,5 & 3 & 1 & 4 & 4,5 & 7 & 25 \\
\hline & $v_{63}$ & 4 & 3 & 4 & 4 & 4,5 & 4 & 23,5 \\
\hline & $v_{64}$ & 1,5 & 3 & 2 & 2 & 4,5 & 1 & 14 \\
\hline & $v_{65}$ & 3 & 3 & 3 & 1 & 4,5 & 2 & 16,5 \\
\hline & $v_{66}$ & 7 & 6 & 6 & 6,5 & 4,5 & 5,5 & 35,5 \\
\hline & $v_{67}$ & 5,5 & 7 & 8 & 6,5 & 4,5 & 5,5 & 37 \\
\hline & $v_{68}$ & 8 & 8 & 7 & 8 & 4,5 & 8 & 43,5 \\
\hline \multirow{4}{*}{$V_{7}$} & $v_{71}$ & 1 & 1 & 1 & 1 & 1 & 1,5 & 6,5 \\
\hline & $v_{72}$ & 3 & 3 & 2 & 3 & 4 & 3 & 18 \\
\hline & $v_{73}$ & 4 & 4 & 3 & 4 & 2,5 & 4 & 21,5 \\
\hline & $v_{74}$ & 2 & 2 & 4 & 2 & 2,5 & 1,5 & 14 \\
\hline
\end{tabular}


3.3 lentelès pabaiga

\begin{tabular}{|c|c|c|c|c|c|c|c|c|}
\hline \multirow{2}{*}{ Veiksniai } & \multirow{2}{*}{$\begin{array}{l}\text { Daliniai } \\
\text { veiksniai }\end{array}$} & \multicolumn{6}{|c|}{ Ekspertai } & \multirow{2}{*}{$\begin{array}{l}\text { Rangu } \\
\text { suma }\end{array}$} \\
\hline & & 1 & 2 & 3 & 4 & 5 & 6 & \\
\hline \multirow{5}{*}{$V_{8}$} & $v_{81}$ & 1,5 & 1 & 2 & 1,5 & 1,5 & 1 & 8,5 \\
\hline & $v_{82}$ & 3 & 3 & 4 & 3 & 4,5 & 4 & 21,5 \\
\hline & $v_{83}$ & 1,5 & 2 & 1 & 1,5 & 1,5 & 2 & 9,5 \\
\hline & $v_{84}$ & 2 & 4 & 3 & 4 & 3 & 3 & 19 \\
\hline & $v_{85}$ & 4 & 5 & 5 & 5 & 4,5 & 5 & 28,5 \\
\hline \multirow{4}{*}{$V_{9}$} & $v_{91}$ & 2 & 1,5 & 2 & 2,5 & 2 & 2 & 12 \\
\hline & $v_{92}$ & 4 & 4 & 4 & 4 & 4 & 4 & 24 \\
\hline & $v_{93}$ & 3 & 1,5 & 3 & 2,5 & 3 & 3 & 16 \\
\hline & $v_{94}$ & 1 & 3 & 1 & 1 & 1 & 1 & 8 \\
\hline \multirow{5}{*}{$V_{10}$} & $v_{101}$ & 5 & 5 & 5 & 5 & 5 & 5 & 30 \\
\hline & $v_{102}$ & 2,5 & 2,5 & 4 & 3,5 & 3 & 2 & 17,5 \\
\hline & $v_{103}$ & 2,5 & 2,5 & 2 & 1,5 & 2 & 2 & 12,5 \\
\hline & $v_{104}$ & 4 & 4 & 3 & 3,5 & 4 & 4 & 22,5 \\
\hline & $v_{105}$ & 1 & 1 & 1 & 1,5 & 1 & 2 & 7,5 \\
\hline
\end{tabular}

Saltinis: sudaryta autorès

Rezultatai (3.4 lentelè) rodo, kad konkordancijos koeficientai yra reikšmingi ir ekspertų nuomonès yra suderintos tikimybei esant 0,99 .

3.4 lentelè. Konkordancijos koeficientų $W$ ir jų reikšmingumų $\chi^{2}$ reikšmès

Table 3.4. The values of concordance coefficients $W$ and its significances $\chi^{2}$

\begin{tabular}{|l|c|c|c|c|}
\hline Veiksniai & $S$ & $W$ & $\chi^{2}$ & $\chi_{k r}$ \\
\hline Institucinè aplinka $V_{l}$ & 133,5 & 0,87 & 12,98 & 11,35 \\
\hline Inžinerinè infrastruktūra $V_{2}$ & 314 & 0,92 & 20,66 & 13,28 \\
\hline Technologinè infrastruktūra $V_{3}$ & 478,5 & 0,84 & 22,02 & 15,09 \\
\hline Mokslinè infrastruktūra $V_{4}$ & 284,5 & 0,84 & 18,68 & 13,28 \\
\hline Švietimas $V_{5}$ & 132,5 & 0,80 & 13,05 & 11,35 \\
\hline Socialinè aplinka $V_{6}$ & 776 & 0,66 & 19,36 & 18,48 \\
\hline Produktų rinka $V_{7}$ & 124,5 & 0,72 & 12,37 & 11,35 \\
\hline Darbo rinka $V_{8}$ & 286 & 0,82 & 18,90 & 13,28 \\
\hline Finansų rinka $V_{9}$ & 140 & 0,80 & 13,91 & 11,35 \\
\hline Verslo pažanga $V_{10}$ & 305 & 0,91 & 19,98 & 13,28 \\
\hline
\end{tabular}

Śaltinis: sudaryta autorès

Atsižvelgiant ị tai, kad visus veiksnius (išskyrus socialinès aplinkos) sudarančių dalinių veiksnių skaičius yra mažesnis už 7, jų atžvilgiu nustatytu kriterijumi $\chi^{2}$, nors jis ir didesnis už $\chi_{k r}$, pasitiketi negalima. Tokiu atveju suskaičiuotos $\chi^{2}$ reikšmès yra patikrinamos naudojantis tikimybinèmis konkordancijos koeficiento lentelèmis (Бешелев, Гурвич 1980). Atsižvelgiant i lyginamu 
veiksnių skaičių $n$ bei ekspertų skaičių $r=6$ nustatyta, kad tikimybè, jog veiksnių rangų sumų nuokrypių nuo bendro vidurkio kvadratų sumos $S$ (3.4 lentelè) bus pasiektos arba viršytos, lygi praktiškai nuliui, t. y. ìvykis realiai neįmanomas. O tai reiškia, kad ekspertų vertinimus galima lakyti labai gerai suderintais.

Kadangi tenkinamos visos numatytos sąlygos, Lietuvos konkurencingumo veiksnius sudarančių dalinių veiksnių reikšmingumai $w_{j i}$ yra 3.5 lentelëje pateiktos vidutinès dalinių veiksnių reikšmingumų reikšmès.

3.5 lentelè. Dalinių veiksnių santykinių reikšmingumų ekspertų vertinimai

Table 3.5. The expert valuations of relative significances of sub-factors

\begin{tabular}{|c|c|c|c|c|c|c|c|c|}
\hline \multirow{2}{*}{ Veiksniai } & \multirow{2}{*}{$\begin{array}{l}\text { Daliniai } \\
\text { veiksniai }\end{array}$} & \multicolumn{6}{|c|}{ Ekspertai } & \multirow[b]{2}{*}{$w_{j i}$} \\
\hline & & 1 & 2 & 3 & 4 & 5 & 6 & \\
\hline \multirow{4}{*}{$V_{1}$} & $v_{11}$ & 0,37 & 0,38 & 0,29 & 0,24 & 0,31 & 0,38 & 0,33 \\
\hline & $v_{12}$ & 0,37 & 0,34 & 0,29 & 0,35 & 0,31 & 0,38 & 0,34 \\
\hline & $v_{13}$ & 0,16 & 0,18 & 0,21 & 0,21 & 0,31 & 0,16 & 0,20 \\
\hline & $v_{14}$ & 0,09 & 0,10 & 0,21 & 0,21 & 0,06 & 0,08 & 0,12 \\
\hline \multirow{5}{*}{$V_{2}$} & $v_{21}$ & 0,34 & 0,22 & 0,27 & 0,37 & 0,27 & 0,19 & 0,28 \\
\hline & $v_{22}$ & 0,16 & 0,18 & 0,16 & 0,17 & 0,11 & 0,15 & 0,15 \\
\hline & $v_{23}$ & 0,10 & 0,18 & 0,12 & 0,11 & 0,16 & 0,15 & 0,14 \\
\hline & $v_{24}$ & 0,05 & 0,07 & 0,09 & 0,06 & 0,08 & 0,15 & 0,09 \\
\hline & $v_{25}$ & 0,34 & 0,35 & 0,36 & 0,30 & 0,38 & 0,36 & 0,35 \\
\hline \multirow{6}{*}{$V_{3}$} & $v_{31}$ & 0,03 & 0,16 & 0,02 & 0,04 & 0,02 & 0,05 & 0,05 \\
\hline & $v_{32}$ & 0,22 & 0,22 & 0,13 & 0,23 & 0,19 & 0,15 & 0,19 \\
\hline & $v_{33}$ & 0,22 & 0,19 & 0,15 & 0,14 & 0,19 & 0,18 & 0,18 \\
\hline & $v_{34}$ & 0,08 & 0,06 & 0,13 & 0,13 & 0,13 & 0,12 & 0,11 \\
\hline & $v_{35}$ & 0,22 & 0,19 & 0,18 & 0,23 & 0,23 & 0,26 & 0,22 \\
\hline & $v_{36}$ & 0,22 & 0,19 & 0,40 & 0,23 & 0,23 & 0,26 & 0,25 \\
\hline \multirow{5}{*}{$V_{4}$} & $v_{41}$ & 0,32 & 0,27 & 0,27 & 0,36 & 0,25 & 0,25 & 0,29 \\
\hline & $v_{42}$ & 0,32 & 0,27 & 0,22 & 0,20 & 0,25 & 0,25 & 0,25 \\
\hline & $v_{43}$ & 0,19 & 0,27 & 0,21 & 0,12 & 0,18 & 0,18 & 0,19 \\
\hline & $v_{44}$ & 0,06 & 0,07 & 0,11 & 0,09 & 0,09 & 0,09 & 0,08 \\
\hline & $v_{45}$ & 0,11 & 0,11 & 0,19 & 0,23 & 0,23 & 0,23 & 0,19 \\
\hline \multirow{4}{*}{$V_{5}$} & $v_{51}$ & 0,07 & 0,09 & 0,10 & 0,08 & 0,07 & 0,19 & 0,10 \\
\hline & $v_{52}$ & 0,28 & 0,37 & 0,27 & 0,29 & 0,28 & 0,25 & 0,29 \\
\hline & $v_{53}$ & 0,32 & 0,37 & 0,30 & 0,31 & 0,32 & 0,25 & 0,31 \\
\hline & $v_{54}$ & 0,32 & 0,16 & 0,32 & 0,31 & 0,32 & 0,32 & 0,29 \\
\hline \multirow{6}{*}{$V_{6}$} & $v_{61}$ & 0,22 & 0,16 & 0,12 & 0,12 & 0,13 & 0,19 & 0,16 \\
\hline & $v_{62}$ & 0,08 & 0,16 & 0,18 & 0,12 & 0,13 & 0,08 & 0,12 \\
\hline & $v_{63}$ & 0,09 & 0,16 & 0,14 & 0,12 & 0,13 & 0,09 & 0,12 \\
\hline & $v_{64}$ & 0,22 & 0,16 & 0,16 & 0,14 & 0,13 & 0,23 & 0,17 \\
\hline & $v_{65}$ & 0,20 & 0,16 & 0,14 & 0,33 & 0,13 & 0,20 & 0,19 \\
\hline & $v_{66}$ & 0,07 & 0,09 & 0,10 & 0,06 & 0,13 & 0,08 & 0,09 \\
\hline
\end{tabular}


3.5 lentelès pabaiga

\begin{tabular}{|c|c|c|c|c|c|c|c|c|}
\hline \multirow[t]{2}{*}{ Veiksniai } & \multirow{2}{*}{$\begin{array}{l}\text { Daliniai } \\
\text { veiksniai }\end{array}$} & \multicolumn{6}{|c|}{ Ekspertai } & \multirow[t]{2}{*}{$w_{j i}$} \\
\hline & & 1 & 2 & 3 & 4 & 5 & 6 & \\
\hline \multirow{2}{*}{$V_{6}$} & $v_{67}$ & 0,08 & 0,05 & 0,06 & 0,06 & 0,13 & 0,08 & 0,08 \\
\hline & $v_{68}$ & 0,03 & 0,05 & 0,09 & 0,05 & 0,13 & 0,04 & 0,07 \\
\hline \multirow{4}{*}{$V_{7}$} & $v_{71}$ & 0,39 & 0,39 & 0,39 & 0,43 & 0,32 & 0,37 & 0,38 \\
\hline & $v_{72}$ & 0,22 & 0,17 & 0,37 & 0,18 & 0,19 & 0,16 & 0,22 \\
\hline & $v_{73}$ & 0,10 & 0,13 & 0,15 & 0,16 & 0,25 & 0,09 & 0,15 \\
\hline & $v_{74}$ & 0,29 & 0,30 & 0,09 & 0,23 & 0,25 & 0,37 & 0,26 \\
\hline \multirow{5}{*}{$V_{8}$} & $v_{81}$ & 0,33 & 0,48 & 0,29 & 0,33 & 0,28 & 0,35 & 0,34 \\
\hline & $v_{82}$ & 0,11 & 0,13 & 0,12 & 0,15 & 0,14 & 0,13 & 0,13 \\
\hline & $v_{83}$ & 0,33 & 0,25 & 0,34 & 0,33 & 0,28 & 0,27 & 0,30 \\
\hline & $v_{84}$ & 0,14 & 0,09 & 0,14 & 0,14 & 0,16 & 0,14 & 0,14 \\
\hline & $v_{85}$ & 0,09 & 0,05 & 0,11 & 0,05 & 0,14 & 0,11 & 0,09 \\
\hline \multirow{4}{*}{$V_{9}$} & $v_{91}$ & 0,31 & 0,39 & 0,28 & 0,19 & 0,29 & 0,32 & 0,30 \\
\hline & $v_{92}$ & 0,07 & 0,07 & 0,14 & 0,10 & 0,10 & 0,08 & 0,09 \\
\hline & $v_{93}$ & 0,21 & 0,39 & 0,21 & 0,19 & 0,22 & 0,22 & 0,24 \\
\hline & $v_{94}$ & 0,41 & 0,15 & 0,37 & 0,53 & 0,39 & 0,38 & 0,37 \\
\hline \multirow{5}{*}{$V_{10}$} & $v_{101}$ & 0,08 & 0,05 & 0,11 & 0,05 & 0,10 & 0,07 & 0,08 \\
\hline & $v_{102}$ & 0,23 & 0,23 & 0,14 & 0,13 & 0,18 & 0,27 & 0,20 \\
\hline & $v_{103}$ & 0,23 & 0,23 & 0,24 & 0,34 & 0,26 & 0,27 & 0,26 \\
\hline & $v_{104}$ & 0,18 & 0,17 & 0,16 & 0,13 & 0,12 & 0,11 & 0,14 \\
\hline & $v_{105}$ & 0,28 & 0,32 & 0,35 & 0,34 & 0,34 & 0,27 & 0,32 \\
\hline
\end{tabular}

Saltinis: sudaryta autorès

Nustačius dalinių veiksnių $v_{j i}$ reikšmes ir santykinius reikšmingumus $w_{j i}$ naudojantis 2.3 formule apskaičiuojamos Lietuvos konkurencingumą lemiančių veiksnių reikšmès $V_{j}$ (3.6 lentelè).

3.6 lentelè. Lietuvos konkurencingumą lemiančių veiksnių $V_{j}$ reikšmès

Table 3.6. The values of Lithuania's competitiveness factors $V_{j}$

\begin{tabular}{|l|c|}
\hline \multicolumn{1}{|c|}{ Veiksniai } & Reikšmès \\
\hline Institucinė aplinka $V_{l}$ & 0,72 \\
\hline Inžinerinè infrastruktūra $V_{2}$ & 0,38 \\
\hline Technologinè infrastruktūra $V_{3}$ & 0,44 \\
\hline Mokslinė infrastruktūra $V_{4}$ & 0,44 \\
\hline Švietimas $V_{5}$ & 0,55 \\
\hline Socialinė aplinka $V_{6}$ & 0,55 \\
\hline Produktų rinka $V_{7}$ & 0,65 \\
\hline Darbo rinka $V_{8}$ & 0,60 \\
\hline Finansų rinka $V_{9}$ & 0,46 \\
\hline Verslo pažanga $V_{10}$ & 0,54 \\
\hline
\end{tabular}


Analogiškai daliniams veiksniams, toliau nustatomi Lietuvos konkurencingumą lemiančių veiksnių santykiniai reikšmingumai. Apskaičiavus indeksus $S_{I}$ ir santykius $S_{S}$, nustatytas ekspertų vertinimų nepriekaištingumas (3.7 lentelè).

3.7 lentelè. Suderinamumo indekso $S_{I}$ ir santykio $S_{S}$ reikšmès

Table 3.7. The values of consistency indexes $S_{I}$ and ratio $S_{S}$

\begin{tabular}{|l|c|c|c|c|c|c|}
\hline \multirow{2}{*}{ Reikšmės } & \multicolumn{6}{|c|}{ Ekspertai } \\
\cline { 2 - 7 } & 1 & 2 & 3 & 4 & 5 & 6 \\
\hline$S_{I}$ & 0,086 & 0,011 & 0,041 & 0,086 & 0,033 & 0,093 \\
\hline$S_{S}$ & 0,058 & 0,008 & 0,027 & 0,058 & 0,022 & 0,062 \\
\hline
\end{tabular}

Šaltinis: sudaryta autorès

Nustačius veiksnių rangus (3.8 lentelè), apskaičiuotas konkordancijos koeficientas $W=0,59$ ir $\chi^{2}=26,55>\chi_{k r}=21,67$, kurių reikšmès atskleidžia ekspertų nuomonių suderinamumą.

3.8 lentelè. Lietuvos konkurencingumo veiksnių reikšmingumų rangai

Table 3.8. The ranks of significances of Lithuania's competitiveness factors

\begin{tabular}{|c|c|c|c|c|c|c|c|}
\hline \multirow{2}{*}{ Veiksniai } & \multicolumn{6}{|c|}{ Ekspertai } & \multirow{2}{*}{ Rangų sume } \\
\hline & 1 & 2 & 3 & 4 & 5 & 6 & \\
\hline Institucinè aplinka $V_{l}$ & 10 & 9 & 9 & 10 & 9 & 10 & 57 \\
\hline Inžinerinè infrastruktūra $V_{2}$ & 3 & 4,5 & 4,5 & 4 & 5 & 8,5 & 29,5 \\
\hline Technologinè infrastruktūra $V_{3}$ & 6 & 4,5 & 9 & 6 & 5 & 8,5 & 39 \\
\hline Mokslinè infrastruktūra $V_{4}$ & 7,5 & 4,5 & 9 & 9 & 5 & 2 & 37 \\
\hline Švietimas $V_{5}$ & 4 & 4,5 & 4,5 & 4 & 7 & 2 & 26 \\
\hline Socialinè aplinka $V_{6}$ & 9 & 4,5 & 7 & 8 & 8 & 2 & 38,5 \\
\hline Produktų rinka $V_{7}$ & 1,5 & 4,5 & 1,5 & 1,5 & 2 & 4,5 & 15,5 \\
\hline Darbo rinka $V_{8}$ & 1,5 & 4,5 & 1,5 & 1,5 & 2 & 4,5 & 15,5 \\
\hline Finansu rinka $V_{9}$ & 5 & 4,5 & 3 & 4 & 2 & 7 & 25,5 \\
\hline Verslo pažanga $V_{l 0}$ & 7,5 & 10 & 6 & 7 & 10 & 6 & 46,5 \\
\hline
\end{tabular}

Šaltinis: sudaryta autorès

3.9 lenteleje pateikiami Lietuvos konkurencingumą lemiančių veiksnių santykiniai reikšmingumai (ekspertų pateiktų reikšmingumų vidurkiai) $w_{j}$.

Žinant Lietuvos konkurencingumą lemiančių veiksnių reikšmes $V_{j}$ ir santykinius reikšmingumus $w_{j}$ naudojantis 2.4 formule randamas Lietuvos konkurencingumo rodiklis $K=0,531$. 
3.9 lentelè. Lietuvos konkurencingumo veiksnių santykiniai reikšmingumai $w_{j}$

Table 3.9. The relative significances $w_{j}$ of Lithuania's competitiveness factors

\begin{tabular}{|c|c|c|c|c|c|c|c|}
\hline \multirow{2}{*}{ Veiksniai } & \multicolumn{6}{|c|}{ Ekspertai } & \multirow{2}{*}{$w_{j}$} \\
\hline & 1 & 2 & 3 & 4 & 5 & 6 & \\
\hline Institucinė aplinka $V_{l}$ & 0,03 & 0,10 & 0,07 & 0,03 & 0,05 & 0,06 & 0,06 \\
\hline $\begin{array}{l}\text { Inžinerinė } \\
\text { infrastruktūra } V_{2}\end{array}$ & 0,15 & 0,11 & 0,10 & 0,14 & 0,11 & 0,07 & 0,11 \\
\hline $\begin{array}{l}\text { Technologinė } \\
\text { infrastruktūra } V_{3}\end{array}$ & 0,08 & 0,11 & 0,07 & 0,07 & 0,11 & 0,07 & 0,09 \\
\hline Mokslinè infrastruktūra $V_{4}$ & 0,06 & 0,11 & 0,07 & 0,04 & 0,11 & 0,13 & 0,09 \\
\hline Švietimas $V_{5}$ & 0,14 & 0,11 & 0,10 & 0,14 & 0,10 & 0,13 & 0,12 \\
\hline Socialinė aplinka $V_{6}$ & 0,05 & 0,11 & 0,08 & 0,05 & 0,08 & 0,13 & 0,08 \\
\hline Produktų rinka $V_{7}$ & 0,16 & 0,11 & 0,14 & 0,16 & 0,13 & 0,11 & 0,13 \\
\hline Darbo rinka $V_{8}$ & 0,16 & 0,11 & 0,14 & 0,16 & 0,13 & 0,11 & 0,13 \\
\hline Finansų rinka $V_{9}$ & 0,13 & 0,11 & 0,13 & 0,14 & 0,13 & 0,09 & 0,12 \\
\hline Verslo pažanga $V_{10}$ & 0,06 & 0,04 & 0,09 & 0,06 & 0,04 & 0,10 & 0,07 \\
\hline
\end{tabular}

Saltinis: sudaryta autorès

Lietuvos konkurencingumo pokyčio optimizavimas. Siekiant išspręsti Lietuvos konkurencingumo pokyčio optimizavimo uždavinį, pirmiausia nustatomos uždavinio parametrų reikšmès. Uždavinio sprendimui reikalingos konkurencingumo veiksnių reikšmingumų $w_{j}$ reikšmès nustatytos atliekant Lietuvos konkurencingumo vertinimą (3.9 lentelè). Siekiant nustatyti kitus parametrus ir išsprendus uždavini gauti optimalaus finansinių išteklių paskirstymo planą, atliekami tokie veiksmai:

1. Priimamas sprendimas dèl vieno piniginio vieneto reikšmès.

2. Nustatomi ekspertiniai šalies konkurencingumo veiksnių būklès pokyčių dèl investuoto vieno piniginio vieneto įverčiai - atsitiktiniai dydžiai $s_{j}$.

3. Apskaičiuojamos atsitiktinių dydžių $s_{j}$ skaitinès charakteristikos vidurkis $E s_{j}$ ir dispersija $D s_{j}$.

4. Priimamas sprendimas dèl Lietuvos konkurencingumo skatinimui skiriamos finansinių išteklių sumos $c$.

5. Išsprendžiamas optimizavimo uždavinys.

Lietuvos konkurencingumą lemiančių veiksnių būklès pokyčių įverčiai nustatomi atliekant ekspertini vertinimą, kuriame dalyvavo anksčiau minèti ekspertai. Ekspertams buvo pateikiamos lentelès ir prašoma jose nurodyti numanomą kiekvieno Lietuvos konkurencingumą lemiančio veiksnio būklès pagerèjimą (pokyti) procentais dèl $i \mathrm{j}$ ji investuotų $100 \mathrm{mln}$. Lt. Vertinimo rezultatai pateikti 3.10 lentelèje. 
3.10 lentelè. Ekspertų pateikti veiksnių pokyčių ịverčiai, proc.

Table 3.10. Estimated changes of factors presented by experts, percent

\begin{tabular}{|l|c|c|c|c|c|c|}
\hline \multicolumn{1}{|c|}{ Veiksniai } & \multicolumn{6}{c|}{ Ekspertai } \\
\cline { 2 - 7 } & 1 & 2 & 3 & 4 & 5 & 6 \\
\hline Institucinė aplinka $V_{l}$ & 10 & 1 & 2 & 2 & 10 & 5 \\
\hline Inžinerinè infrastruktūra $V_{2}$ & 2,5 & 5 & 6 & 3 & 2 & 1 \\
\hline Technologinè infrastruktūra $V_{3}$ & 5 & 5 & 8 & 7 & 2 & 4 \\
\hline Mokslinè infrastruktūra $V_{4}$ & 5 & 2 & 4 & 8 & 8 & 8 \\
\hline Švietimas $V_{5}$ & 5 & 1 & 3 & 4 & 8 & 8 \\
\hline Socialinė aplinka $V_{6}$ & 10 & 1 & 3 & 3 & 5 & 12 \\
\hline Produktų rinka $V_{7}$ & 5 & 1 & 10 & 8 & 2 & 5 \\
\hline Darbo rinka $V_{8}$ & 5 & 1 & 4 & 10 & 5 & 4 \\
\hline Finansų rinka $V_{9}$ & 2,5 & 1 & 5 & 8 & 2 & 8 \\
\hline Verslo pažanga $V_{10}$ & 10 & 1 & 10 & 5 & 2 & 12 \\
\hline
\end{tabular}

Šaltinis: sudaryta autorès

3.10 lentelèje pateiktų įverčių skaitinès charakteristikos - vidurkis ir dispersija nustatomos naudojantis 2.16 ir 2.17 formulèmis (3.11 lentelè).

3.11 lentelè. Atsitiktinių dydžių $s_{j}$ skaitinès charakteristikos

Table 3.11. The numerical characteristics of random values $s_{j}$

\begin{tabular}{|l|c|c|}
\hline \multicolumn{1}{|c|}{ Veiksniai } & Vidurkis & Dispersija \\
\hline Institucinė aplinka $V_{l}$ & 5 & 16,8 \\
\hline Inžinerinè infrastruktūra $V_{2}$ & 3,3 & 3,6 \\
\hline Technologinè infrastruktūra $V_{3}$ & 5,2 & 4,6 \\
\hline Mokslinè infrastruktūra $V_{4}$ & 5,8 & 6,6 \\
\hline Švietimas $V_{5}$ & 4,8 & 7,8 \\
\hline Socialinė aplinka $V_{6}$ & 5,7 & 19,1 \\
\hline Produktų rinka $V_{7}$ & 5,2 & 11,8 \\
\hline Darbo rinka $V_{8}$ & 4,8 & 8,6 \\
\hline Finansų rinka $V_{9}$ & 4,4 & 9,4 \\
\hline Verslo pažanga $V_{10}$ & 6,7 & 21,5 \\
\hline
\end{tabular}

Šaltinis: sudaryta autorès

Priimama, kad Lietuvos konkurencingumo skatinimui skiriama $1 \mathrm{mlrd}$. Lt suma. Sprendžiant optimizavimo uždavini investicijos yra išreiškiamos piniginiais vienetais. $100 \mathrm{mln}$. Lt suma prilyginama vienam piniginiam vienetui, tokiu atveju, sprendžiant uždavini konkurencingumo skatinimui skiriama 10 piniginių vienetų. 
Optimizavimo uždavinys pagal netiesinio programavimo uždavinio modelị (2.31-2.36) sprendžiamas naudojantis SAS programinès įrangos modulio SAS/OR netiesinio programavimo procedūra NLP.

Siekiant gauti skirtingus uždavinio sprendimo variantus, skaičiavimai atliekami keičiant pasikliovimo lygmenį (tikimybę) $1-\alpha$ ir atitinkamą normaliojo skirstinio kritinę reikšmę $u_{\alpha}$. Uždavinio sprendimui apskaičiuojamos tikslo funkcijos koeficientų $w_{j} E s_{j}$ ir netiesinio apribojimo koeficientu $w_{j}^{2} D s_{j}$ reikšmès (3.12. lentelè).

3.12 lentelè. Tikslo funkcijos ir netiesinio apribojimo koeficientų reikšmès

Table 3.12. The values of coeficients of objective function and nonlenear constrain

\begin{tabular}{|c|c|c|}
\hline Koef. & $\begin{array}{c}\text { Tikslo funkcijos koeficientu } \\
\text { reikšmés }\end{array}$ & $\begin{array}{c}\text { Netiesinio apribojimo koeficientų } \\
\text { reikšmės }\end{array}$ \\
\hline 1 & 0,282129347 & 0,053489163 \\
\hline 2 & 0,374645969 & 0,046399869 \\
\hline 3 & 0,444199851 & 0,033566647 \\
\hline 4 & 0,501364672 & 0,049316859 \\
\hline 5 & 0,58723127 & 0,1167429 \\
\hline 6 & 0,472939766 & 0,131490786 \\
\hline 7 & 0,694339747 & 0,210387229 \\
\hline 8 & 0,640928997 & 0,153333065 \\
\hline 9 & 0,530207144 & 0,136494028 \\
\hline 10 & 0,437595134 & 0,091713617 \\
\hline
\end{tabular}

Saltinis: sudaryta autorès

Naudojant 3.12 lentelèje pateiktas reikšmes, uždavinys SAS/OR netiesinio programavimo procedūros NLP lange užrašomas taip:

proc nlp;

$\max \Delta \mathrm{K}$

parms z, x1, x2, x3, x4, x5, x6, x7, x8, x9, x10;

bounds $\times 1-x 10>=0$;

nlincon $\mathrm{d}=0$;

lincon $\mathrm{x} 1+\mathrm{x} 2+\mathrm{x} 3+\mathrm{x} 4+\mathrm{x} 5+\mathrm{x} 6+\mathrm{x} 7+\mathrm{x} 8+\mathrm{x} 9+\mathrm{x} 10$;

$\mathrm{d}=\mathrm{z} * \mathrm{z}-(0,053489163 * \mathrm{x} 1 * \mathrm{x} 1+0,046399869 * \mathrm{x} 2 * \mathrm{x} 2+0,033566647 * \mathrm{x} 3 * \mathrm{x} 3+$

$0,049316859 * x 4 * x 4+0,1167429 * x 5 * x 5+0,131490786 * x 6 * x 6+0,210387229 * x$ $7 * x 7+0,153333065 * x 8 * x 8+0,136494028 * x 9 * x 9+0,091713617 * x 10 * x 10)$; $\Delta \mathrm{K}=0,282129347 * \mathrm{x} 1+0,374645969 * \mathrm{x} 2+0,444199851 * \mathrm{x} 3+0,501364672 * \mathrm{x} 4+0$, $58723127 * \mathrm{x} 5+0,472939766 * \mathrm{x} 6+0,694339747 * \mathrm{x} 7+0,640928997 * \mathrm{x} 8+0,530207$ $144 * x 9+0,437595134 * x 10-0253347 * z$;

run; 
Pateiktame uždavinio užrašyme pasirinkta tikimybè 0,6 , tokiu atveju normaliojo skirstinio kritinè reikšmè $u_{\alpha}$ lygi 0,253347 . Normaliojo skirstinio kritinès reikšmès, esant kitokiai tikimybei, pateiktos 3.13 lentelèje.

3.13 lentelè. Normaliojo skirstinio kritinès reikšmès

Table 3.13. Critical values of normal distribution

\begin{tabular}{|c|c|c|c|c|c|c|}
\hline $1-\alpha$ & 0,6 & 0,7 & 0,8 & 0,9 & 0,95 & 0,99 \\
\hline$u_{\alpha}$ & 0,253347 & 0,524401 & 0,841621 & 1,281552 & 1,644854 & 2,326348 \\
\hline
\end{tabular}

Šaltinis: sudaryta autorès remiantis tikimybių teorija

Optimizavimo uždavinio sprendiniai pateikti D priede ir 3.14 lenteleje.

3.14 lentelè. Optimizavimo uždavinio sprendiniai

Table 3.14. The solutions of optimization task

\begin{tabular}{|c|c|c|c|c|c|c|c|c|c|c|c|}
\hline $1-\alpha$ & 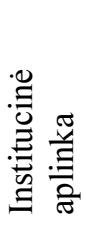 & 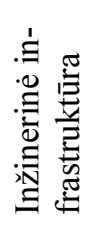 & 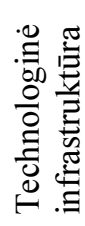 & 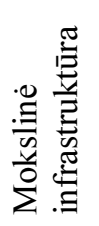 & 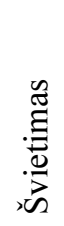 & 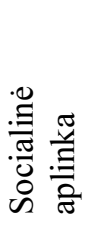 & 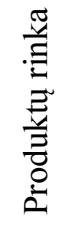 & 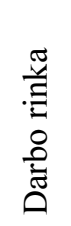 & 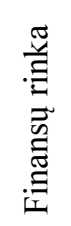 & 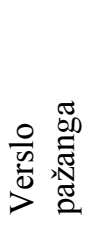 & $\Delta K$ \\
\hline & $x_{1}$ & $x_{2}$ & $x_{3}$ & $x_{4}$ & $x_{5}$ & $x_{6}$ & $x_{7}$ & $x_{8}$ & $x_{9}$ & $x_{10}$ & \\
\hline 0,6 & & & & & & & 6,06 & 3,94 & & & 0,059 \\
\hline 0,7 & & & & & 2,53 & & 3,68 & 3,49 & 0,30 & & 0,052 \\
\hline 0,8 & & & & 1,79 & 2,23 & 0,23 & 2,27 & 2,41 & 1,07 & & 0,046 \\
\hline 0,9 & & & 1,42 & 2,08 & 1,59 & 0,57 & 1,37 & 1,55 & 0,96 & 0,45 & 0,039 \\
\hline 0,95 & & 0,32 & 1,84 & 2,03 & 1,35 & 0,62 & 1,09 & 1,26 & 0,87 & 0,62 & 0,035 \\
\hline 0,99 & 0,01 & 0,86 & 2,09 & 1,92 & 1,13 & 0,63 & 0,84 & 1,01 & 0,78 & 0,73 & 0,028 \\
\hline
\end{tabular}

Śaltinis: sudaryta autorès

3.14 lentelèje pateikti optimizavimo uždavinio sprendiniai rodo piniginių vienetų skaičių, skiriamą tam tikram Lietuvos konkurencingumą lemiančiam veiksniui pasirinkus tam tikrą tikimybę. Tikslo funkcijos verte parodo optimalu Lietuvos konkurencingumo pokyti. 


\subsection{Empirinių tyrimų rezultatų aptarimas}

Atliktas Lietuvos konkurencingumo vertinimas atskleidžia, kad Lietuvos institucinè aplinka, lyginant su kitais konkurencingumą lemiančiais veiksniais, yra geriausios būklès - ji ịvertinta 0,72 balo (3.1 pav.).

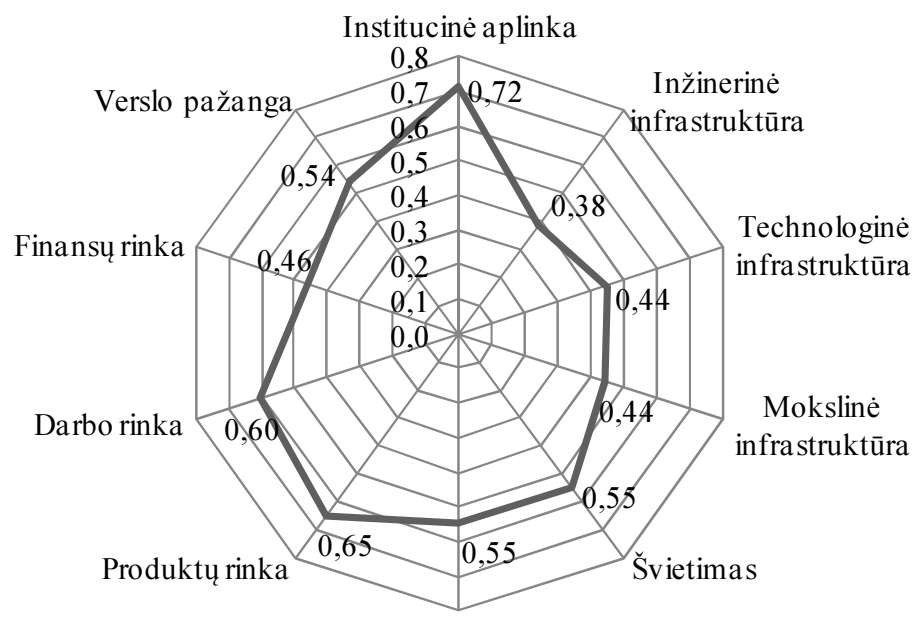

Socialinè aplinka

3.1 pav. Lietuvos konkurencingumo veiksnių esama būklè, balai

Fig. 3.1. The present condition of Lithuania's competitiveness factors, scores Šltinis: sudaryta autorès

Geresnè už vidutinišką yra produktų ir darbo rinkų situacija - atitinkamai ivertintos 0,65 ir 0,60 balo. Maždaug vidutiniškai įvertintos tokios sritys kaip socialinè aplinka $(0,55)$, švietimas $(0,55)$, verslo pažanga $(0,54)$, kiek žemiau nei vidutiniškai - finansų rinka $(0,46)$, mokslinè $(0,44)$ ir technologinè $(0,44)$ infrastruktūra.

Prasčiausia būkle, lyginant su kitais Lietuvos konkurencingumą lemiančiais veiksniais, yra inžinerinès infrastruktūros veiksnio - jis įvertintas 0,38 balo.

Vertinant konkurencingumą lemiančių veiksnių svarbą nustatyta, kad šiuo metu Lietuvai, siekiančiai padidinti savo konkurencingumą svarbiausias yra darbo ir produktų rinku efektyvumas. Darbo rinkos ir produktu rinkos veiksniams nustatytas vienodas $-0,13$ balo reikšmingumas (3.2 pav.). 
Be darbo ir produktų rinkų, svarbios yra ir tokios sritys, kaip švietimas $(0,12)$, finansų rinka $(0,12)$ ir inžinerinè infrastruktūra $(0,11)$. Mažesnis reikšmingumas - po 0,09 balo nustatytas technologinei ir mokslinei infrastruktūrai, o mažiausią reikšmę Lietuvos konkurencingumui turi verslo pažangos ir institucinès aplinkos veiksniai - atitinkamai įvertinti 0,07 ir 0,06 balo.

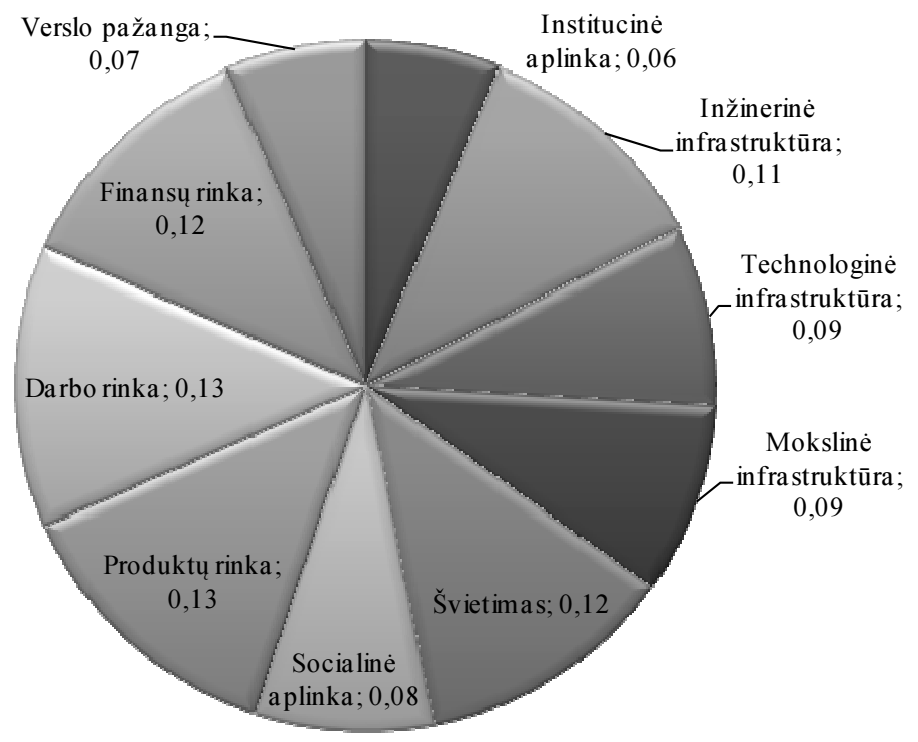

3.2 pav. Lietuvos konkurencingumą lemiančiu veiksnių reikšmingumai, balai

Fig. 3.2. The significances of Lithuania's competitiveness factors, scores Šaltinis: sudaryta autorès

Vertinant investicijų poveikị Lietuvos konkurencingumą lemiantiems veiksniams manoma, kad investavus $100 \mathrm{mln}$. Lt vidutinis didžiausias pokytis būtų jaučiamas verslo pažangos, mokslinès infrastruktūros ir socialinès aplinkos veiksnių būklès pagerejjimo atžvilgiu - atitinkamai 6,7 proc., 5,8 proc. ir 5,7 proc.

Investavus $100 \mathrm{mln}$. Lt ị kitus Lietuvos konkurencingumą lemiančius veiksnius - produktų rinką, technologinę infrastruktūrą, institucinę aplinką, darbo rinką ir finansų rinką, manoma, kad vidutinis jų būklès pagerejjimo pokytis būtų mažesnis - atitinkamai 5,2 proc., 5,2 proc., 5 proc., 4,8 proc. ir 4,4 proc. Mažiausias vidutinis pagerejjimo pokytis investavus $100 \mathrm{mln}$. Lt būtų jaučiamas inžinerinès infrastruktūros veiksnio atžvilgiu $-3,3$ proc. (3.3 pav.).

Sprendžiant Lietuvos konkurencingumo pokyčio optimizavimo uždavinị priimta, kad Lietuvos konkurencingumo skatinimui skiriama 1 mlrd. Lt suma. Išsprendus uždavini gautas finansinių išteklių paskirstymo planas (3.11 lentelè), 
kuris už sprendimų prièmimą atsakingiems subjektams sudaro galimybes, atsižvelgiant ị pasikliovimo lygmenį, rinktis iš skirtingų variantų.

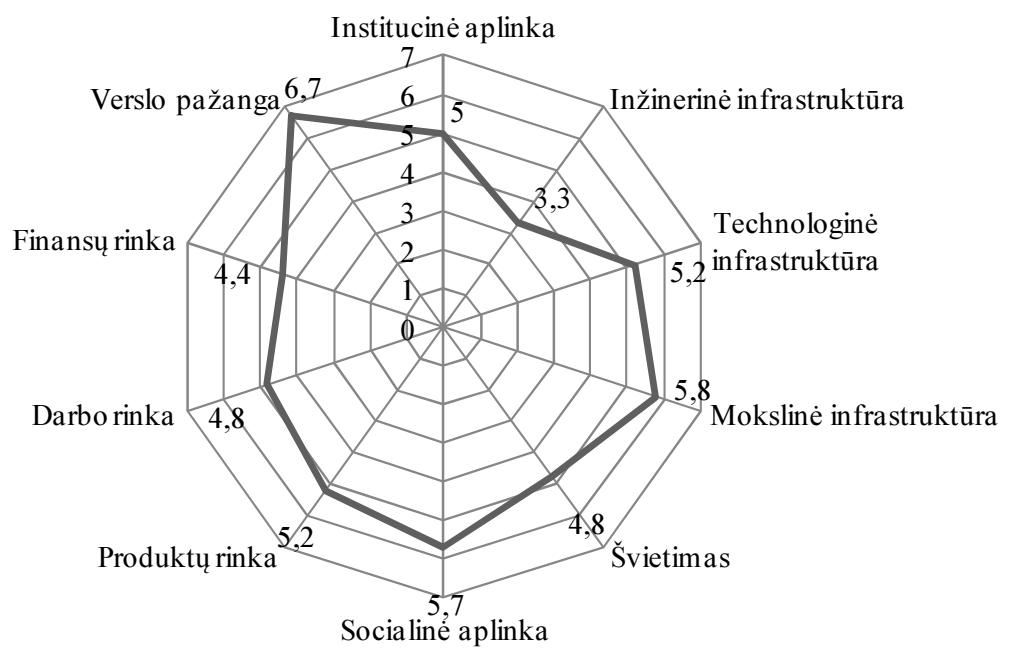

3.3 pav. Konkurencingumo veiksnių būklès pagerèjimo vidutiniai pokyčiu ịverčiai, proc.

Fig. 3.3. The estimates of average changes in improvements of competitiveness factors condition, percents

Šaltinis: sudaryta autorès

Pasirinkus tikimybę 0,6, optimalus Lietuvos konkurencingumo pokytis bus pasiektas visus finansinius išteklius nukreipus produktu rinkos ir darbo rinkos veiksnių būklès gerinimui - darbo rinkai skiriant $394 \mathrm{mln}$. Lt, o produktų rinkai - 606 mln. Lt (3.4 pav. a).

Didinant tikimybę iki 0,7, finansinius išteklius, siekiant optimalaus Lietuvos konkurencingumo pokyčio, derètu paskirstyti jau tarp keturių veiksnių švietimo $(253 \mathrm{mln}$. $\mathrm{Lt})$, produktų rinkos $(368 \mathrm{mln}$. Lt), darbo rinkos $(349 \mathrm{mln}$. $\mathrm{Lt})$ ir finansų rinkos (30 mln. Lt) (3.4 pav. b.). Pasirinkus tikimybę 0,8 , be ịvardintų keturių veiksnių atsiranda dar du veiksniai - socialiné aplinka ir moksliné infrastruktūra (3.4 pav. c.).

Pasirinkus didžiausią tikimybę $(0,99)$, finansinius išteklius tikslinga paskirstyti tarp visų Lietuvos konkurencingumą lemiančių veiksnių, didžiausias sumas - po apytiksliai $200 \mathrm{mln}$. Lt skiriant mokslinès ir technologinès infrastruktūros plètrai (3.4 pav. f.). 
a. Tikimybė 0,$6 ; \Delta K=0,059$

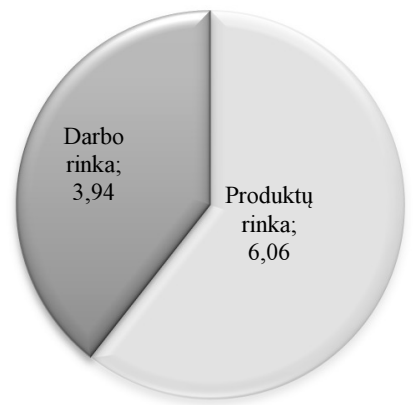

d. Tikimybė 0,$9 ; \Delta K=0,039$

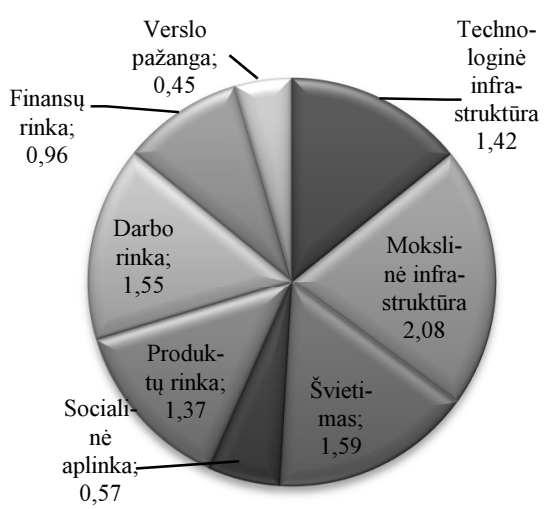

b. Tikimybė 0,$7 ; \Delta K=0,052$

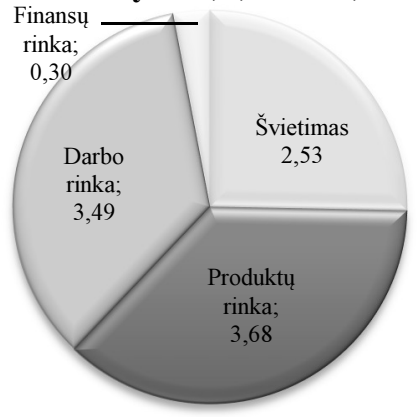

e. Tikimybė 0,$95 ; \Delta K=0,035$

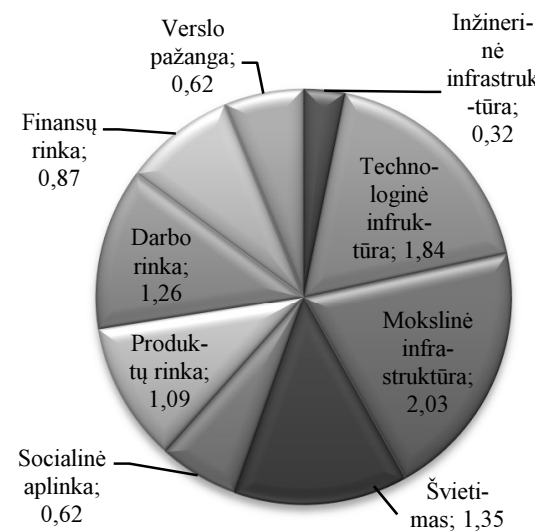

c. Tikimybė 0,$8 ; \Delta K=0,046$

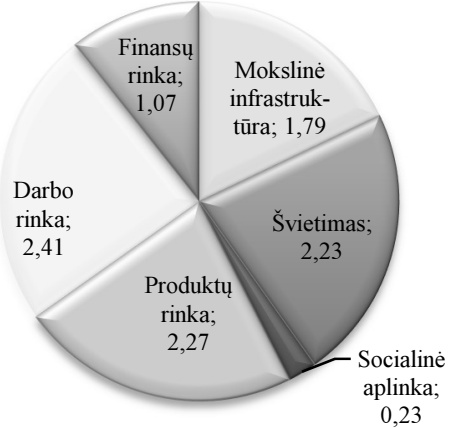

f. Tikimybė 0,$99 ; \Delta K=0,028$

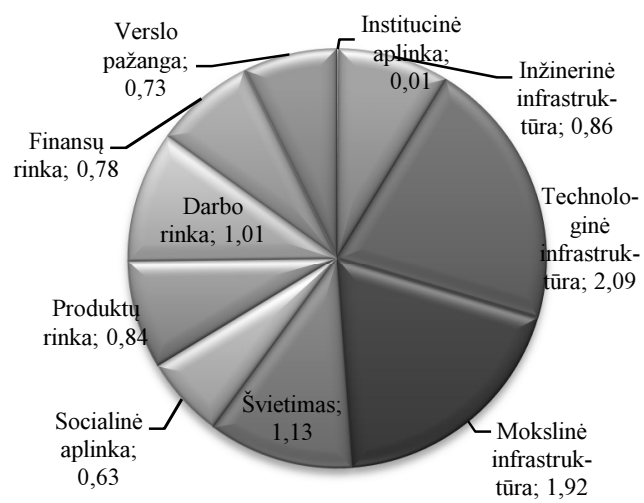

3.4 pav. Finansinių išteklių paskirstymo tarp konkurencingumo veiksnių planas esant tam tikrai tikimybei, vnt. 3.4. Fig. The financial resources' allocaton plan among competitiveness' factors according to probability, units Śaltinis: sudaryta autorès 
Kaip matyti iš 3.4. paveiksle pateiktų grafikų, kuo didesnè tikimybè priimama, tuo sričių i kurias tikslinga nukreipti investicijas, siekiant optimalaus Lietuvos konkurencingumo didejjimo pokyčio, daugeja. Tai atspindi ir 3.5 paveiksle pateiktas grafikas.

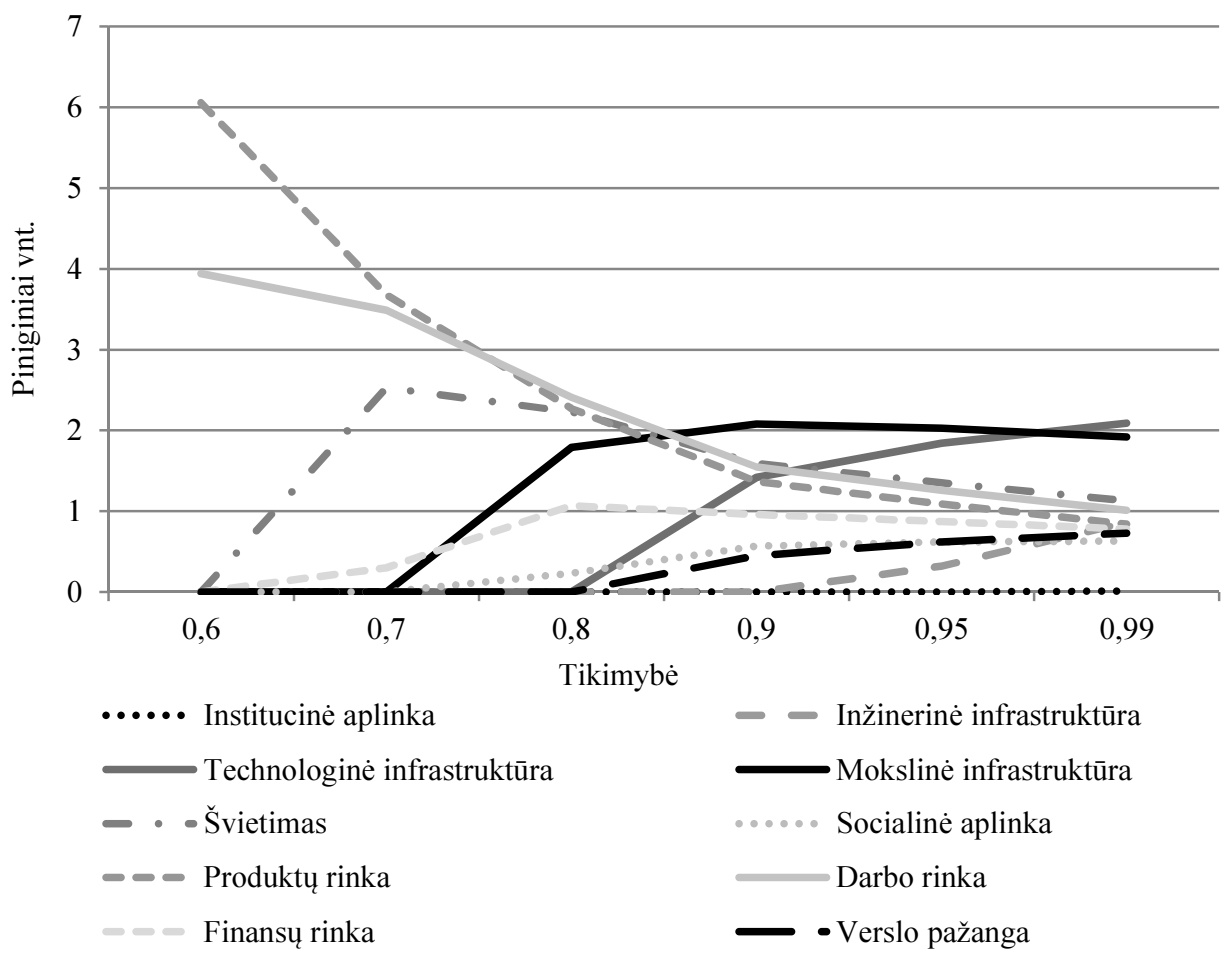

3.5 pav. Finansinių išteklių paskirstymo kitimas keičiantis tikimybei, vnt.

Fig. 3.5. The change of financial resources distribution according to the change of probability, units

Šaltinis: sudaryta autorès

Priimant sprendimą, kurị finansinių išteklių paskirstymo plano variantą pasirinkti, tikslinga ịvertinti tai, kad didelis Lietuvos konkurencingumo pokytis yra mažai tikètinas. Visus finansinius išteklius nukreipus produktų ir darbo rinkų efektyvumui užtikrinti, sėkmės atveju, Lietuvos konkurencingumas padidètų ne mažiau kaip 11 proc. (nuo $K=0,53$ iki $K=0,59$ ). Tačiau tikimybè, kad nepasiseks, taip pat nemaža $-0,4$.

Turimus finansinius išteklius paskirsčius tarp visų Lietuvos konkurencingumo veiksnių, optimalus konkurencingumo pokytis bus dvigubai mažesnis ( 5 proc.) (nuo $K=0,53$ iki $K=0,56$ ), tačiau beveik garantuotas (3.6 pav.). 


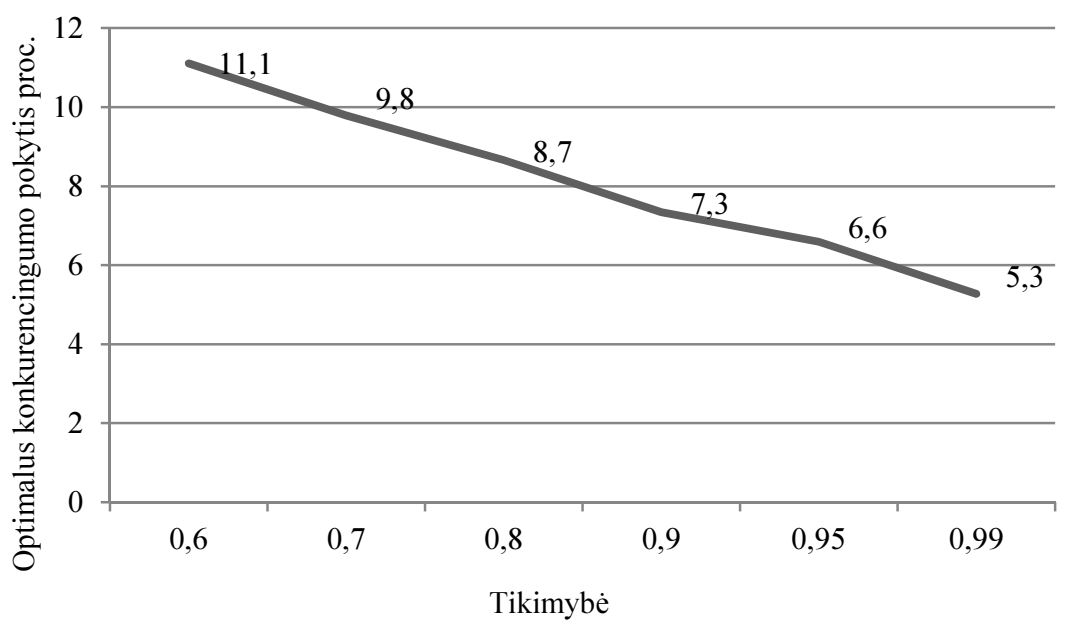

3.6 pav. Konkurencingumo optimalaus pokyčio kitimas keičiantis tikimybei, proc.

Fig. 3.6. The change of competitiveness optimal change according to the change of probability

Šaltinis: sudaryta autorès

\subsection{Trečiojo skyriaus išvados}

1. Siekiant patikrinti darbe pateiktų siūlymų praktinị priimtinumą, atliekami empiriniai tyrimai Lietuvos atveju. Tyrimams reikalinga informacija gauta atlikus statistinių duomenų analizę ir ekspertinius vertinimus, kuriuose dalyvavo 6 ekspertai, glaudžiai susiję su tyrimų objektu. Ekspertinių vertinimų metu gauti kokybinių rodiklių, veiksnių reikšmingumų ir veiksnių pokyčių iverčiai, atitinkamai patikrinus ju tinkamumą, panaudoti Lietuvos konkurencingumo vertinimui ir optimalaus Lietuvos konkurencingumo pokyčio skaičiavimui.

2. Ivertinus Lietuvos konkurencingumą nustatyta, kad, lyginant su kitais Lietuvos konkurencingumą lemiančiais veiksniais, šiandien institucinės aplinkos veiksnio būklè yra geriausia - įvertinta 0,72 balo. Geresnè negu vidutinè situacija yra produktuc ir darbo rinkose - ivertintos atitinkamai 0,65 ir 0,60 balo. Blogiausiai $(0,38$ balo) įvertintas inžinerinès infrastruktūros veiksnys.

3. Vertinant konkurencingumo veiksnių svarbą, nustatyta, kad šiuo metu Lietuvai svarbiausias yra darbo ir produktų rinkų efektyvumas. Šioms sritims nustatytas vienodas $-0,13$ balo reikšmingumas. Kiti svarbūs veiksniai - švietimas $(0,12$ balo), finansų rinka $(0,12$ balo) ir inžinerinè infrastruktūra $(0,11$ balo). Mažesni reikšmingumai - po 0,09 balo nustatyti technologinei ir mokslinei in- 
frastruktūrai, o mažiausią reikšmę Lietuvos konkurencingumui turi verslo pažangos ir institucinès aplinkos veiksniai - atitinkamai įvertinti 0,07 ir 0,06 balo.

4. Vertinant $100 \mathrm{mln}$. Lt investicijų poveiki Lietuvos konkurencingumą lemiantiems veiksniams, manoma, kad didžiausias vidutinis pokytis būtų jaučiamas verslo pažangos, mokslinès infrastruktūros ir socialinès aplinkos veiksnių būklès pagerèjimo atžvilgiu - atitinkamai 6,7 proc., 5,8 proc. ir 5,7 proc., o mažiausias - inžinerinès infrastruktūros ( 3,3 proc.).

5. Lietuvos konkurencingumo pokyčio optimizavimo uždavinys išspręstas priimant, kad investicijų suma sudaro $1 \mathrm{mlrd}$. Lt. Išsprendus uždavinį su tikimybe 0,6 gauta, kad optimalus Lietuvos konkurencingumo pokytis, kuris bus ne mažesnis 11 proc., pasiektinas visus finansinius išteklius nukreipus produktu rinkos (606 mln. Lt) ir darbo rinkos (394 mln. Lt) veiksniams. Didinant tikimybę, sričių, ị kurias turètų būti nukreipiamos investicijos daugejja. Pasirinkus didžiausią tikimybę $(0,99)$ finansinius išteklius tikslinga paskirstyti tarp visų Lietuvos konkurencingumą lemiančių veiksnių, didžiausias sumas - po apytiksliai $200 \mathrm{mln}$. Lt, skiriant mokslinès ir technologinès infrastruktūros plètrai. 



\section{Bendrosios išvados}

1. Šaliu poreikis atremti besikeičiančio pasaulio iššūkius praeito amžiaus antroje pusejje itin padidino šalies konkurencingumo klausimo aktualumą. Ieškodamos efektyvių sprendimų, kai kurių šalių vyriausybès ịsteigè nacionalinio konkurencingumo tarybas, kurioms patikejjo svarbias funkcijas - šalies konkurencingumo vertinimą ir jo rezultatu pagrindu suformuotų rekomendacijų pateikimą už sprendimų prièmimą atsakingiems subjektams. Tačiau, analizuojant šalių patirtị nustatytos problemos - vienareikšmès šalies konkurencingumo sampratos ir pagristo veiksnių rinkinio nebuvimas, remiantis netiksliu vertinimu suformuluotos ir tvirto pagrindimo neturinčios rekomendacijos, atskleide sprendimų priemimo pagrindo nepakankamumą ir sprendimų pagristumui didinti skirtų priemonių poreikį.

2. Mokslinès literatūros analizè atskleide tris požiūrius, skirtingai aiškinančius šalies konkurencingumą tam tikrais laikotarpiais: XVI-XVIII a. pradžioje šalies konkurencingumas buvo vertinamas atsižvelgiant ị prekybos apimtis ir jos ekonominę naudą; XVIII-XX a. pradžioje šalies konkurencingumas vertintas produkcijos gamybos sąnaudomis; XX-XXI a. šalies konkurencingumas pradètas tapatinti su vadyba, inovacijomis, žiniomis ir konkurencinga šalimi laikoma ta, kuri užtikrina savo gyventojų gerovę. Šiandien labiausiai paplitęs požiūris, šalies konkurencingumą tapatinantis su sėkminga jos užsienio prekyba, vertintinas kaip netikslus. Atsižvelgiant ị tai, kad kiekvienos šalies siekis yra 
užtikrinti gyventojų gerovę, prasmę ịgauna našumu grindžiama šalies konkurencingumo samprata, tačiau ji, kertiniu aspektu išlaikant šalies ekonominius laimèjimus, kurie garantuoja materialinę gerovę, turi būti papildyta ir neekonominiai veiksniais. Atsižvelgiant ị tai, šalies konkurencingumas apibrèžiamas kaip jos gebejjimas pasiekti aukštą našumą ir užtikrinti visapusišką gyventojų gerovę.

3. Atlikus skirtingų šalies konkurencingumui vertinti naudojamų veiksnių rinkinių turinio analizę ir sintezę nustatyti patikslintą konkurencingumo apibrèžimą atitinkantys šalies konkurencingumą lemiantys veiksniai: institucinè aplinka, makroekonominè situacija, inžinerinè infrastruktūra, technologinè infrastruktūra, mokslinè infrastruktūra, švietimas, socialinè aplinka, produktų rinka, darbo rinka, finansų rinka, verslo pažanga. Atlikta mokslinès literatūros analizė patvirtino kiekvieno veiksnio svarbą šalies konkurencingumui ir leido apibrèžti turinį.

4. Siekiant padidinti šalies konkurencingumo sprendimų pagrịstumą, darbe pasiūlytas požiūris, pagal kurị sprendimų prièmimo procesas suvokiamas kaip tikslingai tam skirtų finansinių išteklių nukreipimas ị konkurencingumą lemiančius veiksnius, tikintis jų būklès pagerejjimo ir šalies konkurencingumo didejjimo. Remiantis šiuo požiūriu, priimant sprendimus tikslinga ne tik atlikti šalies konkurencingumo vertinimą bet ir išspręsti šalies konkurencingumo pokyčio optimizavimo uždavinị, pateikiantị finansinių išteklių paskirstymo tarp šalies konkurencingumą lemiančių veiksnių planą. Toks sprendimų prièmimo pagrindas sudaro prielaidas pagrịsti ir priimti efektyvesnius sprendimus.

5. Šalies konkurencingumo vertinimui siūlomo metodo pagrindas - remiantis veiksnių rinkinių ir mokslinès literatūros analize sudarytas ir, atsižvelgiant i pasiūlytą šalies konkurencingumo sprendimų prièmimo koncepciją, patikslintas veiksnių rinkinys. Rinkinị sudarantys veiksniai detalizuoti iki dalinių veiksnių, kurių reikšmėms apskaičiuoti, remiantis Lietuvos pavyzdžiu, pasiūlytas rodiklių rinkinys. Dalinių veiksnių ir juos apibūdinančių rodiklių rinkiniai, suteikiant vertinimo metodui lankstumo, nèra baigtiniai ir turi būti tikslinami atsižvelgiant ị konkrečios šalies ypatybes ir vertinimo aplinkybes. Šalies konkurencingumo (veiksnių) būklès vertinimas pagrịstas dalinių veiksnių ir veiksnių vertinimų sinteze, apskaičiuojant veiksnių ir bendro konkurencingumo integruotus kompleksinius rodiklius.

6. Siekiant galimai tiksliau ịvertinti konkurencingumą ir sudaryti realias sąlygas išspręsti šalies konkurencingumo pokyčio optimizavimo uždavinị, siūloma, naudojantis analitinès hierarchijos proceso metodu, kiekvienam šalies konkurencingumo veiksniui ir juos sudarantiems daliniams veiksniams nustatyti skirtingą svarbą atskleidžiančius reikšmingumus. Kitam optimizavimo uždavinio išsprendimui svarbiam klausimui - šalies konkurencingumo veiksnių būklès pokyčių dèl investuotų finansinių išteklių nustatymui, spręsti siūlomas ekspertinio vertinimo metodas. Gautini ekspertų įverčiai, remiantis tikimybių teorija, laikomi atsitiktiniais dydžiais, pasiskirsčiusiais pagal normaluji dèsnį. Atsižvelgiant $\mathfrak{i}$ 
tai, turi būti sprendžiamas stochastinio programavimo uždavinys, kuriam darbe sudarytas šalies konkurencingumo pokyčio optimizavimo modelis.

7. Empirinių tyrimų rezultatai atskleidžia, kad sprendžiamas šalies konkurencingumo pokyčio optimizavimo uždavinys, pasirenkant skirtingus pasikliovimo lygmenis, suteikia galimybę, priimant šalies konkurencingumo sprendimus, rinktis iš skirtingų konkurencingumui skatinti skirtų finansinių išteklių paskirstymo tarp konkurencingumą lemiančių veiksnių variantų. Nustatyta, kad kuo didesnis pasikliovimo lygmuo pasirenkamas, tuo optimalus šalies konkurencingumo pokytis bus mažesnis. Už sprendimų prièmimą atsakingiems subjektams renkantis finansinių išteklių paskirstymo variantą svarbu atsakingai ịvertinti šalies poreikius.

8. Darbe sudaryto šalies konkurencingumo pokyčio optimizavimo modelio taikymas sudaro prielaidas pagrịsti šalies konkurencingumo sprendimus, padidinti konkurencingumo skatinimui skiriamų finansinių išteklių panaudojimo efektyvumą, pasiekti didesnį šalies konkurencingumo augimą. Šalies konkurencingumo vertinimo metodas ne tik igalina nustatyti esamą konkurencingumo būklę, bet ir yra priimamų sprendimų efektyvumo vertinimo priemonè. Pasiūlytų priemoniu pagrindu gali būti sukurta šalies konkurencingumo skatinimo sprendimų paramos sistema. 



\section{Literatūra ir šaltiniai}

Acemoglu, D.; Johnson, S. 2005. Unbundling Institutions, Journal of Political Economy 113(55): 949-995.

Adamopoulos, A. 2010. Stock Market and Economic Growth: An Empirical Analysis for Germany, Business and Economics Journal BEH-1: 1-12.

Agénor, P. R. 2009. Public Capital, Health Persistence and Poverty Traps, Discussion Paper Series. Manchester: Centre for Growth and Business Cycle Research, Economic Studies.

Aghion, P.; Howitt, P. García-Peñalosa C. 1998. Endogenous Growth Theory. Cambridge: MIT Press. 694 p. ISBN 9780262011662.

Aiginger, K. 2006. Competitiveness: From a Dangerous Obsession to a Welfare Creating Ability with Positive Externalities, Journal of Industry, Competition and Trade 6: 161177. DOI: $10.1007 / \mathrm{s} 10842-006-9475-6$.

Aixala, J.; Fabro, G. 2008. Does the Impact of Institutional Quality on Economic Growth Depend on Initial Income Level? Economic Affairs 28(3): 45-49.

Annual Competitiveness Report 2010, Volume 1: Benchmarking Ireland's Performance [interaktyvus]. 2010. National Competitiveness Council [žiūrèta 2010 m. spalio 28 d.]. Prieiga per internetą: <http://www.competitiveness.ie/media/NCC100723acr_bip_2010.pdf>. 
Annual Competitiveness Report 2010, Volume 2: Ireland's Competitiveness Challenge [interaktyvus]. 2010. National Competitiveness Council [žiūrèta 2010 m. spalio 28 d.]. Prieiga per internetą: <http://www.competitiveness.ie/media/ncc100114competitiveness-challenge.pdf $>$.

Annual Competitiveness Report Croatia 2008 [interaktyvus]. 2008. National Competitiveness Council [žiūrèta $2010 \mathrm{~m}$. spalio $28 \mathrm{~d}$.]. Prieiga per internetą: $<$ http://nvk.multilink.hr/english/publications/109_Annual-CompetitivenessReport2008\%5B1\%5D.pdf $>$.

Aron, J. 2000. Growth and Institutions: a Review of the Evidence, The World Bank Research Observer 15(1): 99-135.

Arrison, T. S.; Bergsten, C. F.; Graham, E. M.; Caldwell H. N. 1992. Japan's Growing Technological Capability: Implications for the US Economy. Washington: National Academy Press. 244 p. ISBN 978-0-309-04780-7.

Arvanitis, S.; Loukis E. N. 2009. Information and Communication Technologies, Human Capital, Workplace Organization and Labour Productivity: A Comparative Study Based on rm-level Data for Greece and Switzerland, Information Economics and Policy 21 (1): $43-61$.

Atrostic, B. K.; Boegh-Nielsen; Motohashi K.; Nguyen S. 2002. IT, Productivity and Growth in Enterprises: Evidence from New International Micro Data: Manuscript Prepared for OECD Workshop on ICT and Business Performance. Paris: OECD. 19 p.

Bakštys, A. Statistika ir tikimybe. Vilnius: TEV. 188 p. ISBN 9955-680-42-3.

Bandura, R. 2008. A Survey of Composite Indices Measuring Country Performance: 2008 Update, A UNDP/ODS Working Paper. US: New York. 96 p.

Becsi, Z.; Wang, P. 1997. Financial Development and Growth, Federal Reserve Bank of Atlanta Economic Review, Fourth Quarter: 46-62.

Bencivenga, V. R.; Smith, B. D.; Starr, R. M. 1996. Equity Markets, Transaction Costs, and Capital Accumulation. An Illustration, The World Bank Economic Review 10(2): 241-265.

Berger, T. B. 2008. Concepts of National Competitiveness, Journal of International Business and Economy 9(1): 91-111.

Berger, Th.; Bristow, G. 2009. Competitiveness and Benchmarking of Nations - A Critical Reflection, International Advances in Economic Research 15: 378-392. DOI: 10.1007/s11294-009-9231-x.

Best, M. H. 1993. The New Competition, Institutions of Industrial Restructuring. Cambridge: Harvard University Press. 320 p. ISBN 978-0674609266.

Bhargava, A.; Jamison, D.; Lau, L.; Murray, C. 2001. Modeling the Effects of Health on Economic Growth, Journal of Health Economics 20: 423-440. DOI: 10.1016/S01676296(01)00073-X. 
Bienkowski, W. 2009. How Much are Studies of Competitiveness Worth? Some Reflections on the Issue, Competitiveness of New Europe: Papers from the Second Lancut Economic Forum, 174-188. DOI: 10.4324/9780203892527.ch8.

Blaug, M. 1997. Economic Theory in Retrospect. Cambridge: Cambridge University Press. 725 p. ISBN 0521571537.

Bloom, D. E.; Canning, D.; Sevilla, J. 2004. The Effect of Health on Economic Growth: A Production Function Approach, World Development 32: 1-13. DOI: 10.1016/j.worlddev.2003.07.002.

Boltho, A. 1996. The Assessment: International Competitiveness, Oxford Review of Economic Policy 12 (3): 1-16.

Booysen, F. 2002. An Overview and Evaluation of Composite Indices of Development, Social Indicators Research 59: 115-151. DOI: 10.1023/A:1016275505152.

Boopen, S. 2006. Transport Infrastructure and Economic Growth: Evidence from Africa Using Dynamic Panel Estimates, The Empirical Economics Letters 5(1): 37-52.

Bosma, N.; Stam, E.; Schutjens, V. 2006. Creative Destruction, Economic Competitiveness and Policy, in International Schumpeter Society Conferece. France: Nice. 25 p.

Bosworth, B. P.; Collins, S. M. 2003. The Empirics of Growth: an Update, Brookings Papers on Economic Activity 2: 113-206.

Brouthers, K. D.; Brouthers, L. E. 1997. Explaining National Competitive Advantage for a Small European Country: a Test of Three Competing Models, International Business Review 6: 53-70. DOI: 10.1016/S0969-5931(96)00036-4.

Bruno, M.; Easterly, W. 1998. Inflation Crises and Long-Run Growth, Journal of Monetary Economics 41: 3-26.

Brynjolfsson, E.; Saunders, A. 2010. Wired for Innovation: How Information Technology is Reshaping the Economy. Cambridge, MA: MIT Press. 176 p. ISBN 9780262258074 .

Budd, L.; Hirmis A. 2004. Conceptual Framework for Regional Competitiveness, Regional Studies 38 (9): 1015-1028. DOI: 10.1080/0034340042000292610.

Burgess, S.; Mawson, D. 2003. Aggregate Growth and the Efficiency of Labour Reallocation, CEP Discussion Papers CEPDP 0580. 26 p.

Butkiewicz, J. L.; Yanikkaya, H. 2006. Institutional Quality and Economic Growth: Maintenance of the Rule of Law or Democratic Institutions, or Both? Economic Modelling 23(4): 648-661.

Calderon, C.; Liu, L. 2003. The Direction of Causality Between Financial Development and Economic Growth, Journal of Development Economics 72: 321-334.

Camagni, R. 2002. On the Concept of Territorial Competitiveness: Sound or Misleading? Urban Studies 39(13): 2395-2411. 
Čekanavičius, V.; Murauskas, G. Statistika ir jos taikymas I. Vilnius: TEV, 2000. 239 p. ISBN 9986-546-93-1.

Cho, D. S. 1994. A Dynamic Approach to International Competitiveness: the Case of Korea, Journal of Far Eastern Business, 1(1): 17-36. DOI: 10.1080/ 13602389400000002 .

Cho, D. S.; Moon, H. C. 2002. From Adam Smith to Michael Porter: Evolution of Competitiveness Theory. World Scientific Publishing Co. Pte. Ltd. 244 p. ISBN 9789810246624.

Cho, D. S.; Moon, H. C. 2005. National Competitiveness: Implications for Different Groups and Strategies, International Journal of Global Business Competitiveness 1(1): $1-11$.

Choong, C. K.; Yusop, Z.; Law, S. H.; Liew, V. K. S. 2005. Financial Development and Economic Growth in Malaysia: The Perspective of Stock Market, Investment Management and Financial Innovations 4: 105-115.

Čiburienè, J.; Zaharieva, G. 2006. International Trade as a Factor of Competitiveness: Comparison of Lithuanian and Bulgarian Cases, Engineering Economics 4(49): 48-56.

Čiegis, R. 2006. Ekonominiu teoriju istorija. Vilnius: Vilniaus universiteto leidykla. 732 p. ISBN 9986199255.

Coldwell, D. 2000. The Question of International Competitiveness, International Advances in Economic Research 6(3): 417-426.

Commission of the European Communities [interaktyvus]. 1993. Growth, Competitiveness, Employment: the Challenges and Ways Forward into the 21th Century. White Paper (Bulletin of the European Communities, Supplement 6), Brussels [žiūrèta $2010 \mathrm{~m}$. spalio 28 d.]. Prieiga per internetą: $<$ http://europa.eu/documentation/official-docs/whitepapers/pdf/growth_wp_com_93_700_parts_a_b.pdf $>$.

Commission of the European Communities [interaktyvus]. 1997. Agenda 2000 for a Stronger and Wider Union (Bulletin of the European Union, Supplement 5), Luxembourg [žiūrèta $2010 \mathrm{~m}$. spalio $28 \mathrm{~d}$.]. Prieiga per internetą: $<$ http://www.ab.gov.tr/files/ardb/evt/2_turkiye_ab_iliskileri/2_1_ortaklik_iliskileri/2_1_ 4_diger/gundem_2000_eng.pdf $>$.

Competitiveness Assessment Armenia 2007-2008 [interaktyvus]. 2008. National Competitiveness Council [žiūrèta $2010 \mathrm{~m}$. spalio 28 d.]. Prieiga per internetą: $<$ http://www.competearmenia.org/images/documents/Competitiveness\%20Assessment\% 20Armenia\%202007-2008.pdf $>$.

Coulombe, S.; Tremblay, J. F. 2006. Literacy and Growth, Topics in Macroeconomics 6 (2): article 4.

Council on Czech Competitiveness [interaktyvus]. Prieiga per internetą: $<$ http://www.czechcompete.cz/>. 
Czech Competitiveness Report [interaktyvus]. 2009. Council on Czech Competitiveness [žiūrèta $2010 \mathrm{~m}$. spalio $28 \mathrm{~d}$.]. Prieiga per internetą: $<$ http://www.czechcompete.cz/images/downloads/CzechCompetitiveness2009.pdf>.

Czernich, N.; Falck, O.; Kretschmer, T.; Woessmann, L. 2011. Broadband Infrastructure and Economic Growth, The Economic Journal 121: 505-532. DOI 10.1111/j.14680297.2011.02420.x.

De Gregorio, J. 1993. Inflation, Taxation, and Long-run Growth, Journal of Monetary Economics 31(3): 271-298.

Department of Enterprise, Trade and Innovation [interaktyvus]. Prieiga per internetą: $<$ http://www.deti.ie/>.

Dollar, D.; Wolff, E. N. 1993. Competitiveness, Convergence, and International Specialisation. Cambridge, Massachusetts: The MIT Press. 227 p. ISBN 978-0262041355

Dunford, M. 2005. Growth, Inequality and Cohesion: a Comment on the Sapir Report, Regional Studies 39(7): 972-978. DOI: 10.1080/00343400500290034.

Dunning, J. H. 1993. Internationalizing Porter's Diamond, Management International Review 33(2): 7-15.

Durand, M.; Madaschi, Ch.; Terribile, F. 1998. Trends in OECD Countries' International Competitiveness: the Influence of Emerging Market Economies, Economics Department Working Paper No. 195. OECD Working Papers VI. 57 p.

Efendic, A.; Pugh, G.; Adnett, N. 2008. A Meta-regressions Analysis of the Impact of Institutions on Macroeconomic Performance, in Transitional challenges of EU integration and globalization. Sarajevo: SEBS, 16 p.

Egyptian National Competitiveness Council [interaktyvus. Prieiga per internetą: $<$ http://www.encc.org.eg/>.

Eicher, T.; Leukert, A. 2009. Institutions and Economic Performance: Endogeneity and Parameter Heterogeneity, Journal of Money, Credit and Banking 41(1): 197-219.

Estache, A. 2006. Infrastructure: A Survey of Recent and Upcoming Issues, in Annual Bank Conference on Development Economics - Global 2007, Tokyo, Japan, 2006. Washington, DC: World Bank, 83-85.

Fagerberg, J. 1988. International Competitiveness, The Economic Journal 98: 355-374.

Fagerberg, J. 1996. Technology and Competitiveness, Oxford Review of Economic Policy 12(3): 39-51.

Falcetti, E.; Lysenko, T.; Sanfey, P. 2006. Reforms and Growth in Transition: Reexamining the Evidence, Journal of Comparative Economics 34: 421-445. DOI: 10.1016/j.jce.2006.06.008.

Figueroa, A. 1998. Equity, Foreign Investment and International Competitiveness in Latin America, The Quarterly Review of Economics and Finance 38(3): 391-409. 
Formosa, I. 2008. Measuring Market Efficiency: A Comparative Study, Bank of Valletta Review 38: 8-28.

Forteza, A.; Rama M. 2002. Labor Market Rigidity and the Success of Economic Reforms across More Than One Hundred Countries. Washington: World Bank. 50 p. DOI: 10.1596/1813-9450-2521.

Freudenberg, M. 2003. Composite Indicators of Country Performance: A Critical Assement, STI Working Paper 16. France: Paris. 34 p. DOI: 10.1787/405566708255.

Gagliardi, F. 2008. Institutions and Economic Change: a Critical Survey of the New Institutional Approaches and Empirical Evidence, The Journal of Socio-Economics 37: 416-443.

Garelli, S. 2006. Competitiveness of Nations: the Fundamentals, IMD World competitiveness yearbook 2006. Switzerland: International Institute for Management Development. 12 p.

Gilchrist, S.; Gurbaxani, V.; Town, R. 2001. Productivity and the PC Revolution: Working paper. Irvine: University of California. $28 \mathrm{p}$.

Gilmore, A.; O’Donnell, A.; Carson, D.; Cummins, D. 2003. Factors Influencing Foreign Direct Investment and International Joint Ventures - A Comparative Study of Northern Ireland and Bahrain, International Marketing Review 20 (2): 195-215.

Ginevičius, R. 2004. Statistical View to Development Lithuania: Prospects of Competitiveness in the Enlarged European Union, Journal of Business Economics and Management 5(4): 183-192.

Ginevičius, R. 2006. Daugiakriterinio vertinimo rodiklių svorių nustatymas, remiantis jų tarpusavio sąveika, Verslas: teorija ir praktika [Business: Theory and Practice] 7(1): 313.

Ginevičius, R.; Podvezko, V. 2009. Evaluating the Changes in Economic and Social Development of Lithuanian Countries by Multiple Criteria Methods, Technological and Economic Development of Economy 15(3): 418-436. DOI: 10.3846/13928619.2009.15.418-436.

Ginevičius, R.; Podvezko, V. 2003. Hierarchiškai struktūrizuotų rodiklių reikšmingumo kompleksinis ịvertinimas, Verslas: teorija ir praktika [Business: Theory and Practice] 4(3): 111-116.

Ginevičius, R.; Podvezko, V. 2004. Quantitative Assessing the Accuracy of Expert Methods, Inžineriné ekonomika [Engineering Economics] 5(40): 7-12.

Ginevičius, R.; Podvezko, V. 2005. Objective and Subjective Approaches in Determining the Criterion Weights in Multicriteria Models, Transport and Telecommunication 6(1): 133-137.

Ginevičius, R.; Podvezko, V.; Andruškevičius, A. 2004. Statybos sitemų technologiškumo nustatymas AHP metodu, Ükio technologinis ir ekonominis vystymas [Technological and Economic Development of Economy] 10(4): 135-141. 
Ginevičius, R.; Podvezko, V.; Novotny, M.; Komka, A. 2012. Comprehensive Quantitative Evaluation of the Strategic Potential of an Enterprise, Economic Computation and Economic Cybernetics Studines and Research 46(1): 65-84.

Gough, I. 1996. Social Welfare and Competitiveness, New Political Economy 1(2): 209232. DOI: $10.1080 / 13563469608406253$.

Grant, R. M. Porter's “Competitive Advantage of Nations": An Assessment, Strategic Management Journal, 12(7): 535-548. DOI: 10.1002/smj.4250120706.

Green Egypt: A Vision for tomorrow. The 7th Egyptian Competitiveness Report [interaktyvus]. Egyptian National Competitiveness Council [žiūrèta 2010 m. spalio 28 d.]. Prieiga per internetą:

$<$ http://www.encc.org.eg/Reports/English/Seventh\%20English\%202010.pdf>.

Greenwood, J.; Jovanovic, H. 1990. Financial Development, Growth and the Distribution of Income, Journal of Political Economy 98: 1076-1107. DOI: 10.1086/261720.

Gregorio, D. J.; Guidotti, P. E. 1995. Financial Development and Economic Growth, World Development 23(3): 433-448. DOI: 0305-750X(94)00132-4.

Grein, A. F.; Craig, C. S. 1996. Economic Performance Over Time: does Porter's Diamond Hold at the National Level?, The International Executive 38(3): 303-322. DOI: 10.1002/tie.5060380304.

Griffith, R. 2001. Product Market Competition, Efficiency and Agency Costs: an Empirical Analysis, The Institute for Fiscal Studies Working Papers 01/12. 32 p. DOI: 10.1920/wp.ifs.2001.0112.

Gust, C.; Marquez, J. 2004. International Comparisons of Productivity Growth: the Role of Information Technology and Regulatory Practices, Labour Economics 11: 33-58.

Gwartney, J. D.; Holcombe, R. G.; Lawson, R. A. 2004. Economic Freedom, Institutional Quality, and Cross-country Differences in Income and Growth, Cato Journal 24: 205-233.

Hanushek, E. A.; Wobmann, L. 2010. Education and Economic Growth, in Peterson, P.; Baker, E.; McGaw, B. International Encyclopedia of Education. Oxford: Elsevier, 245252.

Humphrey, T. M. 1999. Mercantilists and Classicals: Insights from Doctrinal History, Economic Quarterly 85(2): 55-82.

Iradian, G. 2009. What Explains the Rapid Growth in Transition Economies? IMF Staff Paper 56: 811-851.

Ireland's Policy Advisory Board for Enterprise, Trade, Science, Technology and Innovation [interaktyvus]. Prieiga per internet: $<\mathrm{http}: / / \mathrm{www}$.forfas.ie/>. 
Isaksson, A. 2010. Energy Infrastructure and Industrial Development, Research and Statistics Branch Working Paper 12/2009. Vienna: United Nations Development Organization. 57 p.

Jacobs, R. P.; Smith, P.; Goddard, M. 2004. Measuring Performance: an Examination of Composite Performance Indicators, Technical Paper Series 29. 124 p.

Jacquemin, A.; Pench, L. R. 1997. Europe Competing in the Global Economy, Reports of the Competitiveness Advisory Group. Cheltham: Edward Elgar Publishing. 204 p. ISBN 978-1858987064.

Jamison, E. A.; Jamison, D. T.; Hanushek, E. A. 2007. The Effects of Education Quality on Mortality Decline and Income Growth, in International Conference on the Economics of Education, Dijon, France, 2006. 38 p.

Jin, B.; Moon, H. C. 2006. The Diamond Approach to the Competitiveness of Korea's Apparel Industry, Journal of Fashion Marketing and Management 10(2): 195-208. DOI: 10.1108/13612020610667504.

Jordan National Competitiveness Observator [interaktyvus]. [žiūrèta $2010 \mathrm{~m}$. spalio 28 d.]. Prieiga per internetą: <http://www.jnco.gov.jo/static/about1.shtm>.

Jordan National Competitiveness Team [interaktyvus]. [žiūrèta 2010 m. spalio 28 d.]. Prieiga per internetą: <http://www.competitiveness.gov.jo/mission.php>.

Jordan's National Competitiveness Report 2008-2009 [interaktyvus]. 2009. Jordan National Competitiveness Observator [žiūrèta $2010 \mathrm{~m}$. spalio $28 \mathrm{~d}$.]. Prieiga per internetą: $<$ http://www.jnco.gov.jo/static/pdf/JCR_2008_2009_INTRODUCTION.pdf $>$

Jovanovic, B.; Rousseau, P. L. 2005. General Purpose Technologies, in Aghion P.; Durlauf S. N. Handbook of Economic Growth. Amsterdam: Elsevier B. V.: 1181-1224.

Kalanta, S. 2007. Taikomosios optimizacijos pagrindai. Vilnius: Technika. 480 p. ISBN 978-9955-28-160-3.

Khan, A. 2000. The Finance and Growth Nexus, Federal Reserve Bank of Philadelphia Business Review, January/February: 3-14.

Ketels, H. M. Christian 2006. Michael Porter's Competitiveness Framework: Recent Learnings and New Research Priorities, Journal of Industry, Competition and Trade 6 (2): 115-136. DOI: 10.1007/s10842-006-9474-7.

Kitzmantel, E. 1995. A Multi-faceted Concept. 35 Years of Free Trade in Europe. Message for the Future, in Proceedings of EFTAs 35th Anniversary Workshop, 106-112.

Klemetti, T. 1989. International Competitiveness and Business Strategies. Golf Industry. Helsinki: Helsinki School of Economics. 117 p. ISBN 9789517006798.

Knack, S. 2002. Institutions and Economic Performance: Property Rights and Contract Enforcement [interaktyvus]. [žiūrèta $2011 \mathrm{~m}$. sausio 20 d.]. Prieiga per internetą: $<$ http://www.iris.umd.edu/NEWS/conferences/conflb.html $>$. 
Knight, J.; Shi, L.; Quheng, D. 2010. Education and the Poverty Trap in Rural China: Closing the Trap, Oxford Development Studies 38(1): 1-24. DOI: $10.1080 / 13600810903551595$.

Kosareva, N.; Krylovas, A. 2009. Tikimybiu teorijos santrauka ir žiniu pasitikrinimo testai. Vilnius: Technika. 176 p. ISBN 978-9955-28-507-6.

Koskivaara, J.; Pilli-Sihvola, J. 1989. International Competitiveness and Business Strategies. Sportswear Industry. Helsinki: Helsinki School of Economics. 174 p. ISBN 95170067569789517006750 .

Koutroumpis, P. 2009. The Economic Impact of Broadband on Growth: A Simultaneous Approach, Telecommunications Policy 33(9): 471-485. DOI: 10.1016/j.telpol.2009.07.004.

Kovačič, A. 2007. Benchmarking the Slovenian Competitiveness by System of Indicators, Benchmarking: An International Journal 14(5): 553-574. DOI: 10.1108/14635770710819254.

Kretschmer, T. 2012. Information and Communication Technologies and Productivity Growth: A Survey of the Literature, OECD Digital Economy Papers. OECD Publishing. 195 p. DOI: $10.1787 / 5 \mathrm{k} 9 \mathrm{bh} 3 \mathrm{jllgs} 7-\mathrm{en}$.

Krugman, P. R. 1996. Making Sense of the Competitiveness Debate, Oxford Review of Economic Policy 12(3): 17-25. DOI:10.1093/oxrep/12.3.17.

Kvainauskaitè, V.; Snieška, V. 2002. Forecastic Evaluation of the Influence of Lithuania's Business Structure Development Tendencies to Regional Economic Growth, Engineering Economics 1(27).

Kwok, Y.; Yu, E. S. H. 2005. Leontief Paradox and the Role of Factor Intensivity Measurement, in Australian Conference of Economists 05: Proceedings of the Australian Conference of Economists 2005. Beijing: Carlton, Vic, 1-20.

Lall, S. 2001. Competitiveness Indices and Developing Countries: An Economic Evaluation of the Global Competitiveness Report, World Development 29(9): 1501-1525.

Landau, R. 1992. Technology, Capital Formalion, and U.S. Competitiveness, in International Productivity and Competitiveness. Oxford: Oxford University Press, 299-325.

Law, S. H.; Bany-Ariffin, A. N. 2008. Institutional Infrastructure and Economic Performance: Dynamic Panel Data Evidence, Transition Studies Review 15: 542-557. DOI: 10.1007/s11300-008-0026-1.

Lawson, C.; Wang, H. 2005. Economic Transition in Central and Eastern Europe and the Former Soviet Union: Which Policies Worked? Centre for Public Policy of the University of Bath Working Paper 1.36 p.

Levine, R.; Loayza, N.; Beck, T. 2000. Financial Intermediation and Growth: Causality and Causes, Journal of Monetary Economics 46: 31-77. 
Levine, R.; Zervos, S. 1998. Capital Control Liberalization and Stock Market Development, World Development 26: 1169-1183. DOI: 10.1016/S0305-750X(98)00046-1.

Lisbon European Council [interaktyvus]. 2000. Presidency Conclusions [žiūrèta 2010 m. sausio 15 d.]. Prieiga per internetą:

$<$ http://www.consilium.europa.eu/uedocs/cms_data/docs/pressdata/en/ec/00100r1.en0.htm>.

Mairesse, J.; Mohnen, P. 2005. The Importance of R\&D for Innovation: A Reassessment Using French Survey Data, in Essays in Honor of Edwin Mansfield, 129-143 p.

Maknickienè, N.; Rutkauskas, A. V.; Maknickas, A. 2011. Investigation of Financial Market Prediction by Recurrent Neural Network, Innovative Technologies for Science, Business and Education 2(11): 3-8.

Maksvytienè, I.; Urbonas, J. 2001. Structure and Powers of a Competitive Ability Model of an Enterprise, Engineering Economics 2(22).

Mankiw, N. G.; Romer, D.; Weil D. N. 1992. A Contribution to the Empirics of Economic Growth, Quarterly Journal of Economics 107 (2): 407-437.

Martin, R. L. 2003. A Study of the Factors of Regional Competitiveness. A Draft Final Report for The European Commission Directorate-General Regional Policy. Cambridge: University of Cambridge. $184 \mathrm{p}$.

Martinez, V.; Sanchez-Robles, B. 2012. Macroeconomic Stability and Growth in Eastern Europe, in Erreygers, G., Vermeire, M. Macroeconomics and Beyond: Essays in Honor of Wim Meeusen. Belgium: Maklu. 310 p.

McFetridge, D. G. 1995. Competitiveness: Concepts and Measures. Occasional Paper no. 5. Ottawa: Industry Canada. 45 p.

Medineckienè, M.; Turskis, Z.; Zavadskas, E. K. 2010. Sustainable Construction Taking into Account the Building Impact on the Environment, Journal of Environmental Engineering and Landscape Management 18(2): 118-127. DOI: 10.3846/jeelm.2010.14

Melody, W. H. 2002. The Triumph and Tragedy of Human Capital: Foundation Resource for the Global Knowledge Economy. Delft: TU Delft. 17 p. ISBN 9789056380960 .

Moon, H C.; Rugman, A. M.; Verbeke, A. 1995. The Generalized Double Diamond Approach to International Competitiveness, Research in Global Strategic Management 5: 97-114. DOI 10.1016/S1064-4857(95)05005-1.

Moon, H. C.; Rugman, A. M.; Verbeke, A. 1998. A Generalized Double Diamond Approach to the Global Competitiveness of Korea and Singapore, International Business Review 7(2): 135-150. DOI: 10.1016/S0969-5931(98)00002-X.

Morgan, K. 2004. Sustainable Regions: Governance, Innovation and Scale, European Planning Studies 12 (6): 871-889. 
Morkvėnas, R. 2010. Organizacijos žiniu potencialo vertinimas: daktaro disertacija. Vilniaus Gedimino technikos universitetas. Vilnius: Technika. 190 p.

Nardo, M.; Saisana, M.; Saltelli, A.; Tarantola, S. 2005. Tools for Composite Indicators Building. European Communities [interaktyvus]. [žiūrèta 2009 m. spalio 6 d.]. Prieiga per internetą: <http://farmweb.jrc.cec.eu.int/ci/bibliography.htm>

National Competitiveness Council [interaktyvus]. [žiūrèta 2010 m. spalio 28 d.]. Prieiga per internetą: <http://nvk.multilink.hr/english/default.asp $>$.

National Competitiveness Council [interaktyvus]. 2010. [žiūrèta 2010 m. spalio 28 d.]. Prieiga per internetą: < http://www.competitiveness.ie/>.

National Competitiveness Council of Armenia [interaktyvus]. 2010. [žiūrèta 2010 m. spalio 28 d.]. Prieiga per internetą:

$<$ http://www.competearmenia.org/index.php?Itemid $=1>$.

National Competitiveness Foundation of Armenia [interaktyvus]. 2010. [žiūrèta 2010 m. spalio 28 d.]. Prieiga per internetą: <http://www.cf.am/>.

Nurbel, A. 2007. The Global Competitiveness of the Nation: A Conceptual Discursion, Journal of Business and Economics Research 5(10): 63-72.

O'Mahony, M.; Vecchi, M. 2005. Quantifying the Impact of ICT on Output Growth: a Heterogeneous Dynamic Panel Approach, Economica 72 (288): 615-633. DOI: 10.1111/j.1468-0335.2005.0435.x.

Orlowski, D. 1997. Die Internationale Wettbewerbsfahigkeit einer Volkswirtschaft. Vandenhoeck \& Ruprecht: Gottingen. 260 p. ISBN 9783525121146.

Oughton, C.; Whittam, G. 1997. Competition and Cooperation in the Small Firm Sector, Scottish Journal of Political Economy 44 (1): 1-30.

Pagano, M. 1993. Financial Markets and Growth: an Overview, European Economic Review 37: 613-622.

Papageorgiou, C. 2003. Distinguishing Between the Effects of Primary and Postprimary Education on Economic Growth, Review of Development Economics 7(1): 1-22. DOI: 10.1111/1467-9361.00213.

Papyrakis, E.; Gerlagh, R. 2004. The Resource Curse Hypothesis and Its Transmission Channels, Journal of Comparative Economics 32 (March): 181-193. DOI: 10.1016/j.jce.2003.11.002.

Pautrel, X. 2009. Pollution, Private Investment in Healthcare, and Environmental Policy, The Scandinavian Journal of Economics 114(2): 334-357. DOI: 10.1111/j.14679442.2012.01696.x.

Petrakis, P. E.; Stamatakis, D. 2002. Growth and Educational Levels: A Comparative Analysis, Economics of Education Review 21: 513-521. 
Petterson, B. 2001. The National Competitiveness Council of Ireland, Presentation to the National Competitiveness Council of Croatia.

Pham, N. D. 2010. The Impact of Innovation and the Role of Intellectual Property Rights on U.S. Productivity, Competitiveness, Jobs, Wages, and Exports: Executive Summary. Washington: NDP Consulting Group. 75 p.

Phang, S. Y. 2003. Strategic Development of Airport and Rail Infrastructure: the Case of Singapore, Transport Policy 10: 27-33.

Pissarides, C. A. 1997. The Need for Labour-Market Flexibility in European Economic And Monetary Union, Swedish Economic Policy Review 4: 513-546.

Podvezko, V. 2005. Ekspertų ịverčių suderinamumas, Ūkio technologinis ir ekonominis vystymas [Technological and Economic Development of Economy] 11(2): 101-107.

Podvezko, V. 2006. Multicriteria Evaluation Under Uncertainty, Verslas: teorija ir praktika [Business: Theory and Practice] 7(2): 81-88.

Podvezko, V. 2007. Determining the Level of Agreement of Expert Estimates, International Journal of Management and Decision Making 8(5/6): 586-600. DOI: 10.1504/ IJMDM.2007.013420.

Podvezko, V. 2008. Sudètingų dydžių kompleksinis vertinimas, Verslas: teorija ir praktika [Business: Theory and Practice] 9(3): 160-168. DOI: 10.3846/16480627.2008.9.160-168.

Podvezko, V. 2009. Application of AHP Technique, Business Economics and management 10(2):181-189. DOI: 10.3846/1611-1699.2009.10.181-189.

Porter, M. E. 1990. The Competitive Advantage of Nations, Harvard Business Review, 68(2).

Porter, M. E. 1998. The Competitive Advantage of Nations. New York: Free Press, USA. 857 p. ISBN 0684841479.

Porter, M. E. 2003. Clusters and Regional Competitiveness: Recent Learnings, in Clusters 2003: International Conference on Technology Clusters. Monreal.

Poškas, G.; Poškas, P.; Sirvydas, A.; Šimonis, A. 2012. Daugiakriterinès analizès metodo taikymas parenkant Ignalinos AE V1 pastato ịrengimų išmontavimo būdą, Energetika [Energetics] 58(2): 86-96.

Pradhan, R. P.; Bagchi, T. P. 2013. Effect of Transportation Infrastructure on Economic Growth in India: The VECM Approach, Research in Transportation Economics 38(1): 139-148. DOI: 10.1016/j.retrec.2012.05.008.

Reiljan, J.; Henrikus, M.; Ivanov. 2000. A Key Issues in Defining and Analysing the Competitiveness of a Country, Working Paper No. 1. Tartu: Tartu university press. 59 p.

Reinert, E. S. 1995. Competitiveness and its Predecessors - a 500-years Cross-national Perspective, Structural Change and Economic Dynamics 6(1): 23-42. 
Rodrik, D.; Subramanian, A.; Trebbi, F. 2004. Institutions Rule: the Primacy of Institutions Over Geography and Integration in Economic Development, Journal of Economic Growth 9(2): 131-165. DOI: 10.1023/B:JOEG.0000031425.72248.85.

Rondinelli, D. A. 2003. Promoting National Competitiveness in a Globalizing Economy: The State's Changing Roles, in Reinventing Government for the Twenty-First Century. Ed. by D. A. Rondinelli ir G. S. Cheema. USA: Kumarian Press, 33-57.

Romer, P. 1990. Endogenous Technological Change, Journal of Political Economy, 98(5-2): S71-S102.

Rugman, A. M. 1991. Diamond in the Rough, Business Quarterly 55(3): 61-64.

Ruškytė, D.; Rutkauskas, A. V.; Navickas, V. 2013. Mokesčių ir socialinio draudimo ịmokų masto ir struktūros ịtakos darbo rinkai vertinimas pasitelkiant stochastiškai informatyvią ekspertinę sistemą, Verslas: teorija ir praktika [Business: Theory and Practice] 14(2): 83-96. DOI 10.3846/btp.2013.10.

Rutkauskas, A. V. 2008. On the Sustainability of Regional Competitiveness Development Considering Risk, Technological and Economic Development of Economy 14(1): 89-99.

Rutkauskas, A. V. 2012. Stochastically Informed Expertise as Natural Step for Experts Systems Network Development, in Conference Proceedings of the 2nd International Scientific Conference "Whither our Economies - 2012". Vilnius: Mykolas Romeris University, 46-53.

Rutkauskas, A. V.; Stasytytè, V.; Maknickienè, N. 2011. Entrepreneurship Portfolio Construction and Management, in Proceedings of the Annual International Conference on Innovation and Entrepreneuship (IE 2011). Singapore: Global Science and Technology Forum (GSTF), 57-56.

Saaty, T. L. 1990. How to Make Decision: the Analytic Hierarchy Process, European Journal of Operational Research 48: 9-26.

Saaty, T. L. 2005. The Analytic Hierarchy and Analytic Network Processes for the Measurement of Intangible Criteria and for Decision-Making, in Multiple Criteria Decision Analysis: State of the Art Surveys. Ed. by J. Figueira et al. Springer, Chapter 9: 345-408. ISBN 978-0-387-23081-8.

Saaty, T. L. 2008. The Analytic Hierarchy and Analytic Network Measurement Processes: Applications to Decisions under Risk, European Journal of Pure and Applied Mathematics 1(1): 122-196.

Sachs, J.; Warner, A. 2001. The Curse of Natural Resources, European Economic Review 45(4): 827-38.

Sahlberg, P. 2006. Education Reform for Rasing Economic Competitiveness, Journal of Educational Change 7(4): 259-287. DOI: 10.1007/s10833-005-4884-6. 
Scott, B. R.; Lodge, G. C. 1985. US Competitiveness in the World Economy. Boston: Harvard Business School Press. 552 p. ISBN 978-0071032667.

Šeputienè, J. 2009. Institucinès aplinkos poveikio ekonomikai vertinimas: daktaro disertacija. Vilniaus Gedimino technikos universitetas. Vilnius: Technika. 189 p. ISBN 9789955-28-512-0.

Shurchuluu, P. 2002. National Productivity and Competitive Strategies for the New Millennium, Integrated Manufacturing Systems 13(6): 408-414. DOI: 10.1108/09576060210436650.

Siebert, H. 2005. Locational Competition - a Neglected Paradigm in the International Division of Labour, Kiel Working Paper 1258. Kiel: Kiel Institute for World Economics. 35 p.

Sivilevičius, H.; Maskeliūnaitè, L. 2010. The Criteria for Identifying the Quality of Passengers ' Transportation by Railway and Their Ranking Using AHP Method, Transport 25(4): 368-381. DOI: 10.3846/Transport.2010.46.

Snieška, V. 2008. Research into International Competitiveness in 2000-2008, Inžinerinè ekonomika [Engineering Economics] 4(59): 29-41.

Snieška, V.; Bruneckienė, J. 2009. Measurement of Lithuania regions by Regional Competitiveness Index, Inžinerinè ekonomika [Engineering Economics] 1(61): 45- 57.

Snieška, V.; Činčikaitè, J.; Neverauskas, B. 2002. Clusters: A Key to Regional Competitiveness, Inžinerine ekonomika [Engineering Economics] 5(31).

Snieška, V.; Draksaitè, A. 2007. The Role of Knowledge Process Outsourcing in Creating National Competitiveness in Global Economy, Inžinerine ekonomika [Engineering Economic] 3: 35-41.

Snieška, V.; Šliburytė, L. 2000. Competition Research and Competitiveness Management Information System Maintenance, Inžinerinė ekonomika [Engineering Economics] 2(17).

Steinberg, R.; Arndt, O. 2001. What Determines the Innovation Behavior of European Firms? Economic Geography 77(4): 364-382. DOI: $10.1111 / \mathrm{j} .1944-$ 8287.2001.tb00170.x.

Straubhaar, T. 1994. Das Konzept "Internationale Wettbewerbsfähigkeit Einer Voppswirtschaft" auf dem Analytischen Prüfstand: Grundsätzliche Bemerkungen zu einem vielfach (miß-) verwendeten Begriff, in Globale soziale Marktwirtschaft. Gabler: Wiesbaden, 33-51.

Taner, B.; Oncu, S.; Civi, E. 2000. The Relationship Between International Trade and National Competitiveness, in First International Joint Symposium on Business Administration "Challenges for Business Administrators in the New Millennium": selected papers. Çanakkale, 371-383. 
The Global Competitiveness Reports [Pasaulio konkurencingumo ataskaitos]. 2000, 2004, 2008, 2010, 2012. World Economic Forum [žiūrèta 2013-05-21]. Prieiga per internetą: <http://www.weforum.org/en/index.htm>.

The Institute for Industrial Policy Studies [Pramonès politikos studijų institutas] [interaktyvus]. Prieiga per internetą: $<$ http://www.ips.or.kr/english/>.

The International Institute for Management Development [Tarptautinis vadybos plètros institutas] [interaktyvus]. Prieiga per internetą: < http://www.imd.org/wcc/>.

The Organisation for Economic Co-operation and Development [Ekonominio bendradarbiavimo ir pletros organizacija] [interaktyvus]. Prieiga per internetą: < http://www.oecd.org/>.

The World Bank [Pasaulio bankas] [interaktyvus]. Prieiga per internetą: $<$ http://www.worldbank.org/>.

The World Economic Forum [Pasaulio ekonomikos forumas] [interaktyvus]. Prieiga per internetą: <http://www.weforum.org/>.

Thomas, C. 1996. Why National Competition Policy?, Australian Journal of Public Administration 55(2): 100-103.

Thurow, L. 1992. Head to Head: the Coming Economic Battle Among Japan, Europe and America. New York: Warner Books. 336 p. ISBN 978-0446394970.

Tupenaite, L. 2010. Multiple Criteria Assessment of the Built and Human Environment Renovation Projects: Doctoral Dissertation. Vilnius Gediminas Technical university. Vilnius: Technika. 129 p.

Tvaronavičienè, M.; Ginevičius, R.; Grybaitė, V. 2008. Baltijos šalių išsivystymo palyginimas: praktiniai kompleksinio požiūrio taikymo aspektai, Verslas: teorija ir praktika [Business: Theory and Practice] 9(1): 51-64.

Tyson, L. A. 1992. Who's Bashing Whom? Trade Conflict in High-Technology Industries. Washington: Institute for International Economics. 352 p. ISBN 978-0881321067.

Vaidogas, E. R.; Šakènaitè, J. 2011. Multi-Attribute Decision-Making in Economics of Fire Protection, Inžineriné Ekonomika [Engineering Economics] 22(3): 262-270.

Vakrinienè, S. 2003. Operaciju tyrimas programine ịranga SAS/OR. Vilnius: Technika, 2003, 85 p. ISBN 9986-05-676-4.

Valodkienė, G.; Snieška, V. 2012. Tarptautinis konkurencingumas ir ji lemiantys veiksniai ekonomikos nuosmukio laikotarpiu, Economics and Management 17(2): 602-608. DOI 10.5755/j01.em.17.2.2188.

Viassone, M. 2008. Regional Competitive Index as a Tool to Improve Regional Foresight: Theory and Evidence from Two Western-Europe Regions, in 8th Global Conference on Business \& Economics. Italy: Florence. 
Vilpišauskas, R. 2004. Tarptautinis konkurencingumas ir Lietuvos eksporto politika, Pinigų studijos [Monetary Studies]1: 54-69.

Wilson, J. 2008. Territorial Competitiveness and Development Policy. Orkestra, Basque Institute of Competitiveness. Spain: Basque Country. 31 p.

Weede, E.; Kampf, S. 2002. The Impact of Intelligence and Institutional Improvements on Economic Growth, Kyklos 55(3): 361-380.

Woessmann, L. 2003. Schooling Resources, Educational Institutions, and Student Performance: the International Evidence, Oxford Bulletin of Economics and Statistics 65 (2):117-170. DOI: 10.1111/1468-0084.00045.

Wong, A. Zhou, X. 2011. Development of Financial Market and Economic Growth: Review of Hong Kong, China, Japan, The United States and The United Kingdom, International Journal of Economics and Finance 3(2): 111-115. DOI: 10.5539/ijef.v3n2p111.

Zavadskas, E. K.; Kaklauskas, A.; Banaitienè, N. 2001. Pastato gyvavimo proceso daugiakriterinè analizė. Vilnius: Technika, 2001. 380 p. ISBN 9986-05-441-9

Zavadskas, E. K.; Turskis, Z. 2011. Multiple Criteria Decision Making (MCDM) Methods in Economics: an Overview, Technological and Economic Development of Economy 17(2): 397-427. DOI: 10.3846/20294913.2011.593291.

Zavadskas, E. K.; Turskis, Z.; Tamošaitienè, J. 2011. Selection of Construction Enterprises Management Strategy Based on the SWOT and Multi-Criteria Analysis, Civil and Mechanical Engineering 11(4): 1063-1082. DOI: 10.1016/S1644-9665(12)60096-X.

Zinkevičiūtè, V. 2006. Verslo strateginiu sprendimų vertinimas: daktaro disertacija. Vilniaus Gedimino technikos universitetas. Vilnius: Technika. 180 p.

Бешелев, С. Д.; Гурвич, Ф. Г. 1980. Математико статистические методы экспертных оценок. Москва: Статистика. 263 с. 


\section{Autorès mokslinių publikacijų disertacijos tema sąrašas}

Straipsniai recenzuojamuose mokslo žurnaluose

Rakauskienè, G.; Tamošiūnienè, R. 2013. Šalies konkurencingumo pokyčio optimizavimas, Verslo sistemos ir ekonomika [Business Systems \& Economics] 3(2): 167-176. ISSN 2029-8234 (online). (EBSCO)

Rakauskienė, G.; Tamošiūnienė, R. 2013. Šalies konkurencingumą lemiantys veiksniai, Verslas: teorija ir praktika [Business: Theory and Practice] 14(1): 177-187. DOI: 10.3846/btp.2013.19. ISSN 1648-0627. (EBSCO, Business Source Complete)

Tamošiūnienè, R.; Staskevičiūtè (Rakauskienè), G. 2011. Nacionalinio konkurencingumo politikos formavimo praktika, Socialiniu mokslu studijos [Social Sciences Studies] 3(2): 487-503. ISSN 2029-2236. (EBSCO)

Staskevičiūtė (Rakauskienè), G.; Tamošiūnienè, R. 2010. Šalies konkurencingumas: sampratos raida laiko perspektyvoje, Verslas: teorija ir praktika [Business: Theory and Practice] 11(2): 159-167. DOI: 10.3846/btp.2010.18. ISSN 1648-0627. (EBSCO, Business Source Complete) 


\section{Straipsniai kituose leidiniuose}

Staskevičiūtè (Rakauskienè), G.; Tamošiūnienè, R. 2010. The Evaluation of the National Competitiveness: Analysis of Existing Means, The 6th International Scientific Conference Business and Management 2010: selected papers. Vilnius: Technika. 495-503. DOI: 10.3846/bm.2010.066. ISSN 2029-4441. (ISI Proceedings)

Staskevičiūtè (Rakauskienè), G.; Tamošiūnienè, R. 2010. The Analysis of Factors Influencing Competitiveness of Lithuania, III International Science Conference "Knowledge society". Sozopol: KSI Transactions on Kowledge Society; Sofia: Kowledge Society Institute. 19-24. ISSN 1313-4787.

Tamošiūnienè, R.; Staskevičiūtè (Rakauskienè), G. 2009. Knowledge as a Main Factor Influencing National Competitiveness, Second International Science Conference "Knowledge society". Nessebar: KSI Transactions on Kowledge Society; Nessebar: Kowledge Society Institute. 10-12. ISSN 1313-4787. 


\section{Priedai}
A priedas. Dalinių veiksnių rodikliai ir jų gavimo šaltiniai
B priedas. Lietuvos konkurencingumo dalinių veiksnių rodiklių reikšmès
C priedas. Lietuvos konkurencingumo veiksnių reikšmingumų nustatymo pavyzdys
D priedas. Lietuvos konkurencingumo pokyčio optimizavimo uždavinio sprendimo rezultatai 


\section{A priedas. Dalinių veiksnių rodikliai ir jų gavimo šaltiniai}

1 A lentelè. Dalinių konkurencingumo veiksnių rodikliai ir jų gavimo šaltiniai

Table 1A. Sub-factors' indicators and their sources

\begin{tabular}{|c|c|c|c|}
\hline Daliniai veiksniai & Rodikliai & Matmenys & Šaltiniai \\
\hline \multicolumn{4}{|c|}{ Institucinė aplinka } \\
\hline Teisès viršenybė & Teisės viršenybės rodiklis $^{1}$ & Balai & \multirow{4}{*}{$\begin{array}{l}\text { Pasaulio bankas: } \\
\text { Vyriausybès valdymo } \\
\text { rodikliai }\end{array}$} \\
\hline Korupcijos mastas & Korupcijos valdymo rodiklis $^{2}$ & Balai & \\
\hline Reguliavimo kokybè & Reguliavimo kokybès rodiklis $^{3}$ & Balai & \\
\hline Valdžios veiksmingumas & Valdžios veiksmingumo rodiklis ${ }^{4}$ & Balai & \\
\hline \multicolumn{4}{|c|}{ Inžinerinè infrastruktūra } \\
\hline Kelių tinklo infrastruktūra & $\begin{array}{l}\text { Kelių tinklo tankis } \\
\text { Kelių su patobulinta kelio danga kiekis }\end{array}$ & $\begin{array}{l}\mathrm{Km} / 100 \mathrm{~km}^{2} \\
\text { Proc. nuo visu keliu }\end{array}$ & \multirow{4}{*}{$\begin{array}{l}\text { Pasaulio bankas, ES } \\
\text { statistikos tarnyba ir } \\
\text { kitos statistiką } \\
\text { teikiančios institucijos }\end{array}$} \\
\hline Geležinkelių infrastuktūra & Geležinkelio tankumas & $\mathrm{Km} / 100 \mathrm{~km}^{2}$ & \\
\hline Oro transporto infrastruktūra & Naudojimosi oro transportu apimtys & Keleiviu sk./1000 gyv. & \\
\hline Vandens transporto infrastruktūra & Produkcijos transportavimo jūra apimtys & T/gyv. & \\
\hline Energijos perdavimo infrastruktūra & $\begin{array}{l}\text { Sistemos vid. (neplanuotų) elektros energijos } \\
\text { perdavimo nutraukimų trukmé } \\
\text { Sistemos vid. (neplanuotų) elektros energijos } \\
\text { perdavimo nutraukimų dažnis }\end{array}$ & $\begin{array}{l}\text { Min./vartotojui } \\
\text { Sk./vartotojui }\end{array}$ & $\begin{array}{l}\text { Europos energetikos } \\
\text { reguliuotojų taryba } \\
\text { (CEER) }\end{array}$ \\
\hline \multicolumn{4}{|c|}{ Technologinė infrastruktūra } \\
\hline Fiksuoto telefono ryšio prieinamumas & Fiksuoto telefono ryšio linijos & Linijų sk./100 gyv. & \multirow{4}{*}{$\begin{array}{l}\text { PB, ES statistikos } \\
\text { tarnyba; Tarptautinė } \\
\text { telekomunikacijų } \\
\text { sąunga ir kt. }\end{array}$} \\
\hline Judriojo telefono ryšio paplitimas & Judriojo telefono ryšio abonentai & Abonentų sk./100 gyv. & \\
\hline Interneto naudojimas & Interneto prieigos abonentai & Abonentų sk./100 gyv. & \\
\hline Plačiajuosčio ryšio prieinamumas & Plačiajuosčio ryšio skvarba & Linijų sk./ 1000 gyv. & \\
\hline Naujausių technologijų prieinamumas & $\begin{array}{l}\text { Naujausiu technologiju prieinamumo } \\
\text { laisvumas }\end{array}$ & Balai & \multirow[t]{2}{*}{ Ekspertinis vertinimas } \\
\hline $\begin{array}{l}\text { Naujausių technologijų diegimas } \\
\text { imonėse }\end{array}$ & $\begin{array}{l}\text { Naujausiu technologijų taikymo imoniu } \\
\text { veikloje paplitimas }\end{array}$ & Balai & \\
\hline
\end{tabular}


$1 A$ lentelès tęsinys

\begin{tabular}{|c|c|c|c|}
\hline Daliniai veiksniai & Rodikliai & Matmenys & Šaltiniai \\
\hline \multicolumn{4}{|c|}{ Mokslinè infrastruktūra } \\
\hline Inovacijų kūrimo pajègumas & $\begin{array}{l}\text { Imonių pajègumas kurti naujus produktus, } \\
\text { technologijas, paslaugas }\end{array}$ & Balai & \multirow[t]{3}{*}{ Ekspertinis vertinimas } \\
\hline Mokslinių tyrimų institucijų kokybė & Mokslinių tyrimų institucijų kokybė & Balai & \\
\hline $\begin{array}{l}\text { Universitetų ir verslo } \\
\text { bendradarbiavimas }\end{array}$ & $\begin{array}{l}\text { Universitetų ir įmonių bendradarbiavimas } \\
\text { MTEP veikloje }\end{array}$ & Balai & \\
\hline Išradimų patentai & $\begin{array}{l}\text { Išduotų patentų kiekis; } \\
\text { Patentinių paraiškų kiekis }\end{array}$ & $\begin{array}{l}\text { Sk./mln. gyv. } \\
\text { Sk./mln. gyv. }\end{array}$ & \multirow{2}{*}{$\begin{array}{l}\text { Pasaulio intelektualios } \\
\text { nuosavybès organizaci- } \\
\text { ja, PB, ES statist. } \\
\text { tarnyba ir kt. }\end{array}$} \\
\hline $\begin{array}{l}\text { Žmogiškieji ištekliai mokslinėje } \\
\text { veikloje }\end{array}$ & $\begin{array}{l}\text { Darbuotojų, dalyvaujančių MTEP veikloje sk; } \\
\text { Mokslinį laipsnị turinčiujų skaičius }\end{array}$ & $\begin{array}{l}\text { Proc. nuo dirbančiujų } \\
\text { Proc. nuo dirbančiujjų }\end{array}$ & \\
\hline \multicolumn{4}{|c|}{ Svietimas } \\
\hline \multirow[t]{2}{*}{ Pradinis ugdymas } & \multirow{2}{*}{$\begin{array}{l}\text { Pradinio ugdymo neto aprèpties lygis } \\
\text { Pradinio ugdymo kokybė }\end{array}$} & \multirow{2}{*}{$\begin{array}{l}\text { Besimokančiųjų proc. } \\
\text { tipinèje amž. grupejje } \\
\text { Balai }\end{array}$} & Pasaulio bankas ir kt. \\
\hline & & & Ekspertinis vertinimas \\
\hline \multirow[t]{2}{*}{ Aukštesnis mokymas } & \multirow{2}{*}{$\begin{array}{l}\text { Pagrindinio-vidurinio mokymosi neto aprèp- } \\
\text { ties lygis } \\
\text { Mokymosi rezultatai: gamtos mokslai, ma- } \\
\text { tematika, skaitymas }\end{array}$} & \multirow{2}{*}{$\begin{array}{l}\text { Besimokančiųjų proc. } \\
\text { tipinèje amž. grupejje } \\
\text { Skalès taškai }\end{array}$} & Pasaulio bankas ir kt. \\
\hline & & & $\begin{array}{l}\text { EBPO: Tarpt. mokinių } \\
\text { vertinimo programa }\end{array}$ \\
\hline \multirow[t]{2}{*}{ Aukštasis mokslas } & \multirow{2}{*}{$\begin{array}{l}\text { Aukštojo mokslo neto aprèpties lygis } \\
\text { Aukštojo mokslo kokybė }\end{array}$} & \multirow{2}{*}{$\begin{array}{l}\text { Besimokančiųjų proc. } \\
\text { tipinèje amž. grupejje } \\
\text { Balai }\end{array}$} & Pasaulio bankas ir kt. \\
\hline & & & \multirow[t]{2}{*}{ Ekspertinis vertinimas } \\
\hline Darbuotojų mokymas & Darbuotojų mokymų paplitimas įmonès & Balai & \\
\hline \multicolumn{4}{|c|}{ Socialiné aplinka } \\
\hline Gyvenimo trukmè & Vidutinè tikètina gyvenimo trukmè & Metų skaičius & \multirow{4}{*}{$\begin{array}{l}\text { Pasaulio bankas, ES } \\
\text { statistikos tarnyba, } \\
\text { EBPO ir kitos statistiką } \\
\text { teikiančios institucijos }\end{array}$} \\
\hline Kūdikių mirtingumas & Kūdikių mirtingumas & Mirusiųjų sk./1000 gim. & \\
\hline Ligu paplitimas & $\begin{array}{l}\text { Sergamumas aktyvia tuberkulioze } \\
\text { ŽIV paplitimas }\end{array}$ & $\begin{array}{l}\text { Sergančių sk./100000 gyv. } \\
\text { Proc. nuo populiacijos } \\
(15-49 \text { m.) }\end{array}$ & \\
\hline Sveikatos priežiūra & $\begin{array}{l}\text { Bendros praktikos gydytojų kiekis } \\
\text { Lovų kiekis ligoninèse }\end{array}$ & $\begin{array}{l}\text { Gydytojų sk./100000 gyv. } \\
\text { Lovų sk./100000 gyv. }\end{array}$ & \\
\hline
\end{tabular}




\begin{tabular}{|c|c|c|c|}
\hline Daliniai veiksniai & Rodikliai & Matmenys & Šaltiniai \\
\hline Skurdas ir socialinè atskirtis & $\begin{array}{l}\text { Skurdo arba socialinès atskirties rizikos lygis } \\
\text { Materialinio nepritekliaus mastas }\end{array}$ & $\begin{array}{l}\text { Proc. nuo populiacijos } \\
\text { Proc. nuo populiacijos }\end{array}$ & \multirow{4}{*}{$\begin{array}{l}\text { Pasaulio bankas, ES } \\
\text { statistikos tarnyba, } \\
\text { EBPO ir kitos statistiką } \\
\text { teikiančios institucijos }\end{array}$} \\
\hline Oro kokybè & $\begin{array}{l}\text { Šiltnamio efektą sukeliančių dujų emisijos } \\
\text { intensyvumas } \\
\text { Oro užterštumas (Sieros oksidai) }\end{array}$ & $\begin{array}{l}\text { Tūkst.t. CO2 ekvivalen- } \\
\text { tu / mln. Eur BVP } \\
\text { T/mln. Eur BVP }\end{array}$ & \\
\hline Atliekų perdirbimas & Pakuočių atliekų perdirbimo norma & $\begin{array}{l}\text { Proc. nuo bendro } \\
\text { pakuočiu atlieku kiekio }\end{array}$ & \\
\hline Atsinaujinančioji energija & Atsinaujinančiųjų išteklių dalis & $\begin{array}{l}\text { Proc. nuo bendru ener- } \\
\text { gijos sąnaudu }\end{array}$ & \\
\hline \multicolumn{4}{|c|}{ Produktų rinka } \\
\hline Verslo pradžios procedūros & Verslo pradžios rodiklis ${ }^{8}$ & Balai & Pasaulio bankas \\
\hline Mokesčių mokejjimai & Mokesčių mokejjimų rodiklis ${ }^{9}$ & Balai & \multirow[t]{3}{*}{ „Heritage“ fondas } \\
\hline Prekybos laisvè & Prekybos laisvès rodiklis ${ }^{10}$ & Balai & \\
\hline Investavimo laisvè & Investavimo laisvès rodiklis ${ }^{11}$ & Balai & \\
\hline \multicolumn{4}{|c|}{ Darbo rinka } \\
\hline Darbo jègos laisvė & Darbo jègos laisvès indeksas ${ }^{12}$ & Balai & „Heritage“ fondas \\
\hline Santykiai darbo rinkoje & Darbdavių ir darbuotojų santykių pagrindas & Balai & \multirow[t]{3}{*}{ Ekspertinis vertinimas } \\
\hline Užmokestis ir našumas & $\begin{array}{l}\text { Darbo užmokesčio santykis su darbuotojo } \\
\text { našumu }\end{array}$ & Balai & \\
\hline Protų nutekèjimas & $\begin{array}{l}\text { Gebejjimas išlaikyti ir pritraukti talentingus } \\
\text { žmones }\end{array}$ & Balai & \\
\hline Moterys darbo rinkoje & Moterų dalyvavimas darbo rinkoje & Proc. & \\
\hline \multicolumn{4}{|c|}{ Finansų rinka } \\
\hline Finansinių paslaugų prieinamumas & $\begin{array}{l}\text { Finansinio sektoriaus produktų verslui } \\
\text { gausumas }\end{array}$ & Balai & \multirow[t]{2}{*}{ Ekspertinis vertinimas } \\
\hline Vertybinių popierių rinkos veikla & Galimybės gauti lèšų išleidžiant akcijas & Balai & \\
\hline \multirow[t]{2}{*}{ Finansų rinkos patikimumas } & \multirow{2}{*}{$\begin{array}{l}\text { Juridinių teisių stiprumo indeksas } \\
\text { Finansų ir bankininkystès reguliavimo veik- } \\
\text { smingumas }\end{array}$} & \multirow{2}{*}{$\begin{array}{l}\text { Balai } \\
\text { Balai }\end{array}$} & $\begin{array}{l}\text { Pasaulio bankas: pro- } \\
\text { jektas „Doing Business“ }\end{array}$ \\
\hline & & & Ekspertinis vertinimas \\
\hline
\end{tabular}


1A lentelès pabaiga

\begin{tabular}{|c|c|c|c|}
\hline Daliniai veiksniai & Rodikliai & Matmenys & Šaltinis \\
\hline Finansų valdymas & $\begin{array}{l}\text { Paskolos gavimo lengvumas } \\
\text { Rizikos kapitalo prieinamumas }\end{array}$ & $\begin{array}{l}\text { Balai } \\
\text { Balai } \\
\end{array}$ & Ekspertinis vertinimas \\
\hline \multicolumn{4}{|c|}{ Verslo pažanga } \\
\hline Klasteriu plètra & Gerai išplètotų klasterių paplitimas & Balai & \multirow[t]{2}{*}{ Ekspertinis vertinimas } \\
\hline \multirow[t]{3}{*}{ Imonių atskaitomybè } & \multirow{3}{*}{$\begin{array}{l}\text { Auditų ir apskaitos standartų stiprumas } \\
\text { Investuotojų apsaugos stiprumo indeksas }{ }^{14} \\
\text { İmonių valdybų efektyvumas }\end{array}$} & Balai & \\
\hline & & Balai & Pasaulio bankas \\
\hline & & Balai & \multirow[t]{4}{*}{ Ekspertinis vertinimas } \\
\hline Imonių valdymas & $\begin{array}{l}\text { Profesionalaus valdymo paplitimas } \\
\text { Valdymo funkcijų perdavimo praktika }\end{array}$ & $\begin{array}{l}\text { Balai } \\
\text { Balai }\end{array}$ & \\
\hline Verslo kultūra & $\begin{array}{l}\text { Verslo etika } \\
\text { Socialinès atsakomybès lygis }\end{array}$ & $\begin{array}{l}\text { Balai } \\
\text { Balai }\end{array}$ & \\
\hline Strategija ir operacijos & $\begin{array}{l}\text { Vertės kūrimo grandinès plotis } \\
\text { Gamybos proceso modernumas } \\
\text { Rinkodaros naudojimas } \\
\text { Orientacija ị klientus }\end{array}$ & $\begin{array}{l}\text { Balai } \\
\text { Balai } \\
\text { Balai } \\
\text { Balai }\end{array}$ & \\
\hline
\end{tabular}

${ }^{I}$ Teisès viršenybés rodiklis atskleidžia suvokimą apie rinkos dalyvių pasitikejimo ir visuomenės taisyklių laikymosi lygị: sutarčiu vykdymo, nuosavybės teisių ir policijos bei teismų kokybę, nusikalstamumo ir smurto tikimybę. ${ }^{2}$ Korupcijos valdymo rodiklis atskleidžia suvokimą apie korupcijos paplitimo tarp valdžios atstovu mastą. ${ }^{3}$ Reguliavimo kokybes rodiklis atskleidžia suvokimą apie valdžios gebėjimą kurti ir igyvendinti patikimą politiką, kuri leidžia ir skatina privataus sektoriaus plètrą. ${ }^{4}$ Valdžios veiksmingumo rodiklis atskleidžia suvokimą apie viešujų paslaugų ir valstybès tarnybos kokybę, nepriklausomumo nuo politinio spaudimo mastą, politikos formavimo ir igyvendinimo kokybę bei įsipareigojimo jai patikimumą. ${ }^{5}$ Sistemos vidutines (neplanuotu) nutraukimu trukmès rodiklis (SAIDI) parodo, kiek vidutiniškai laiko per ataskaitinị laikotarpi elektros energija nebuvo persiunčiama vienam vartotojui. 'Sistemos (neplanuotu) nutraukimu vidutinio dažnumo rodiklis (SAIFI) parodo, kiek vidutiniškai kartu per ataskaitini laikotarpi elektros energija nebuvo persiunčiama vienam vartotojui. ${ }^{7}$ Verslo pradžios indeksas - vertina verslo pradžios sudètingumą: procedūrų, reikalingų pradèti verslą skaičių, jų atlikimo laiką, išlaidas ir reikalaujamo minimalaus kapitalo dydị. ${ }^{8}$ Mokesčiu mokejimu indeksas - vertina mokesčiu ir įmoku kieki, mokejjimo būdą, dažnị, laiką ir bendrą mokesčiu tarifą. ${ }^{9}$ Prekybos laisvés indeksas - vertina tarifinių ir netarifinių apribojimų, darančiu įtaką importui ir eksportui, egzistavimą. ${ }^{10}$ Investavimo laisvès indeksas - vertina ịvairius investicinei veiklai taikomus apribojimus. ${ }^{11}$ Darbo jègos laisvés indeksas - vertina ịvairius šalies darbo rinkos teisinès ir reguliavimo sistemos aspektus: darbo užmokesčio reguliavimą, atleidimo ir įdarbinimo praktiką, atleidimo išlaidas. ${ }^{12}$ Juridiniu teisiu stiprumo indeksas - matuoja kokiu lygiu ịvairios užtikrinimo priemonès ir bankroto įstatymas apsaugo skolininkų ir kreditorių teises. 


\section{B priedas. Lietuvos konkurencingumo dalinių veiksnių rodiklių reikšmès}

1B lentelè. Lietuvos konkurencingumo dalinių veiksnių rodiklių reikšmès

Table 1B. Values of Lithuania's competitiveness sub-factors' indicators

\begin{tabular}{|c|c|c|c|c|c|c|}
\hline \multirow{2}{*}{ Rodikliai } & \multirow{2}{*}{ Matmenys } & \multirow[t]{2}{*}{ Metai } & \multicolumn{4}{|l|}{ Reikšmės } \\
\hline & & & Lietuvos & Maks. & Min. & Normalizuota \\
\hline Teisès viršenybės rodiklis ${ }^{1}$ & Balai & 2011 & 72,8 & 100 & 0 & 0,73 \\
\hline Korupcijos valdymo rodiklis ${ }^{2}$ & Balai & 2011 & 65,9 & 100 & 0 & 0,66 \\
\hline Reguliavimo kokybės rodiklis ${ }^{3}$ & Balai & 2011 & 78,7 & 100 & 0 & 0,79 \\
\hline Valdžios veiksmingumo rodiklis $^{4}$ & Balai & 2011 & 72 & 100 & 0 & 0,72 \\
\hline Kelių tinklo tankis & $\mathrm{Km} / 100 \mathrm{~km}^{2}$ & 2010 & 1240,9 & 6959 & 124,9 & 0,16 \\
\hline Kelių su patobulinta kelio danga kiekis & Proc. nuo visų kelių & & 29,3 & 100 & 20,9 & 0,11 \\
\hline Geležinkelio tankumas & $\mathrm{Km} / 100 \mathrm{~km}^{2}$ & 2010 & 27,06 & 122,1 & 0 & 0,22 \\
\hline Naudojimosi oro transportu apimtys & Keleivių sk./1000 gyv. & 2010 & 700 & 9003 & 348 & 0,04 \\
\hline Produkcijos transportavimo jūra apimtys & T/gyv. & 2010 & 14,1 & 40,2 & 1,5 & 0,33 \\
\hline $\begin{array}{l}\text { Sistemos vid. (neplanuotu) el. energijos perdavimo } \\
\text { nutraukimų trukme }{ }^{5}\end{array}$ & Min./vartotojui & 2010 & 118 & 638 & 15 & 0,83 \\
\hline $\begin{array}{l}\text { Sistemos vid. (neplanuotu) el. energijos perdavimo } \\
\text { nutraukimų dažnis }\end{array}$ & Sk./vartotojui & 2010 & 1,6 & 6,1 & 0,25 & 0,77 \\
\hline Fiksuoto telefono ryšio linijos & Linijų sk./100 gyv. & 2010 & 22,1 & 63,72 & 20,12 & 0,05 \\
\hline Judriojo telefono ryšio abonentai & Abonentų sk./100 gyv. & 2010 & 147,2 & 185,3 & 93,7 & 0,58 \\
\hline Interneto prieigos abonentai & Abonentų sk./100 gyv. & 2010 & 20,62 & 39,06 & 12,97 & 0,29 \\
\hline Plačiajuosčio ryšio skvarba & Linijų sk./ 1000 gyv. & 2010 & 195,5 & 383,7 & 136,9 & 0,24 \\
\hline Naujausių technologijų prieinamumo laisvumas & Balai & 2013 & 0,62 & 1 & 0 & 0,62 \\
\hline $\begin{array}{l}\text { Naujausių technologijų taikymo imonių veikloje } \\
\text { paplitimas }\end{array}$ & Balai & 2013 & 0,47 & 1 & 0 & 0,47 \\
\hline $\begin{array}{l}\text { Imoniu pajègumas kurti naujus produktus, technologijas, } \\
\text { paslaugas }\end{array}$ & Balai & 2013 & 0,52 & 1 & 0 & 0,52 \\
\hline Moksliniu tyrimu instituciju kokybė & Balai & 2013 & 0,5 & 1 & 0 & 0,50 \\
\hline
\end{tabular}


1B lentelès tęsinys

\begin{tabular}{|c|c|c|c|c|c|c|}
\hline \multirow[t]{2}{*}{ Rodikliai } & \multirow[t]{2}{*}{ Matmenys } & \multirow{2}{*}{ Metai } & \multicolumn{4}{|l|}{ Reikšmès } \\
\hline & & & Lietuvos & Maks. & Min. & Normalizuota \\
\hline $\begin{array}{l}\text { Universitetų ir įmonių bendradarbiavimas MTEP } \\
\text { veikloje }\end{array}$ & Balai & 2013 & 0,53 & 1 & 0 & 0,53 \\
\hline Išduotų patentų kiekis; & Sk./mln. gyv. & 2011 & 35,1 & 2232 & 19,4 & 0,01 \\
\hline Patentinių paraiškų kiekis & & 2011 & 33 & 1012 & 25 & 0,01 \\
\hline $\begin{array}{l}\text { Darbuotoju, dalyvaujančiu MTEP veikloje skaičius; } \\
\text { Mokslini laipsni turinčiuju skaičius }\end{array}$ & $\begin{array}{l}\text { Proc. nuo dirbančiuju } \\
\text { Proc. nuo dirbančiuju }\end{array}$ & $\begin{array}{l}2010 \\
2010\end{array}$ & $\begin{array}{l}1,41 \\
1,05\end{array}$ & $\begin{array}{l}3,27 \\
2,34\end{array}$ & $\begin{array}{l}0,42 \\
0,33\end{array}$ & $\begin{array}{l}0,35 \\
0,36\end{array}$ \\
\hline $\begin{array}{l}\text { Pradinio ugdymo neto aprèpties lygis } \\
\text { Pradinio ugdymo kokybe }\end{array}$ & $\begin{array}{l}\text { Besimokančiu proc. } \\
\text { tipinèje amž. grupejje } \\
\text { Balai }\end{array}$ & $\begin{array}{l}2011 \\
2013\end{array}$ & 0,6 & 100 & 88 & 0,25 \\
\hline $\begin{array}{l}\text { Pagrindinio-vidurinio mokymosi neto aprèpties lygis } \\
\text { Mokymosi rezultatai: gamtos mokslai, matematika, } \\
\text { skaitymas }\end{array}$ & $\begin{array}{l}\text { Besimokančių proc. } \\
\text { tipinèje amž. grupèje } \\
\text { Skalès taškai }\end{array}$ & $\begin{array}{l}2011 \\
2009\end{array}$ & $\begin{array}{c}91 \\
478,7\end{array}$ & $\begin{array}{r}99 \\
543,7\end{array}$ & 83 & 0,50 \\
\hline $\begin{array}{l}\text { Aukštojo mokslo neto aprèpties lygis } \\
\text { Aukštojo mokslo kokybė }\end{array}$ & $\begin{array}{l}\text { Besimokančiu proc. } \\
\text { tipinèje amž. grupèje } \\
\text { Balai }\end{array}$ & 2011 & $\begin{array}{r}69 \\
0,63\end{array}$ & $\begin{array}{l}94 \\
1\end{array}$ & $\begin{array}{l}11 \\
0\end{array}$ & 0,70 \\
\hline Darbuotojų mokymų paplitimas įmonès & Balai & 2013 & 0,5 & 1 & 0 & 0,50 \\
\hline Vidutinè tiketina gyvenimo trukmè & Metų skaičius & 2011 & 73,1 & 82,2 & 70,7 & 0,21 \\
\hline Kūdikių mirtingumas & Mirusių sk./1000 gim. & 2011 & 4,2 & 12,6 & 0,9 & 0,72 \\
\hline $\begin{array}{l}\text { Sergamumas aktyvia tuberkulioze } \\
\text { ŽIV paplitimas }\end{array}$ & $\begin{array}{l}\text { Serg. sk./100000 gyv. } \\
\text { Proc. nuo populiacijos } \\
(15-49 \text { m.) }\end{array}$ & 2011 & 0,1 & 101 & 0,1 & 0,43 \\
\hline $\begin{array}{l}\text { Bendros praktikos gydytojų kiekis } \\
\text { Lovų kiekis ligoninėse }\end{array}$ & $\begin{array}{l}\text { Gydyt. sk. /100000gyv. } \\
\text { Lovu sk./100000 gyv. }\end{array}$ & $\begin{array}{l}2010 \\
2010\end{array}$ & $\begin{array}{l}372 \\
675\end{array}$ & $\begin{array}{l}478 \\
825\end{array}$ & $\begin{array}{l}218 \\
252\end{array}$ & $\begin{array}{l}0,59 \\
0,74\end{array}$ \\
\hline $\begin{array}{l}\text { Skurdo arba socialinès atskirties rizikos lygis } \\
\text { Materialinio nepritekliaus mastas }\end{array}$ & $\begin{array}{l}\text { Proc. nuo populiacijos } \\
\text { Proc. nuo populiacijos }\end{array}$ & $\begin{array}{l}2011 \\
2011\end{array}$ & $\begin{array}{l}33,4 \\
18,5\end{array}$ & $\begin{array}{l}49,1 \\
43,6\end{array}$ & $\begin{array}{c}13,7 \\
1\end{array}$ & $\begin{array}{l}0,44 \\
0,59\end{array}$ \\
\hline $\begin{array}{l}\text { Šiltnamio efektą sukeliančių dujų emisijos intensyvumas } \\
\text { Oro užterštumas (Sieros oksidai) }\end{array}$ & $\begin{array}{l}\text { Tūkst. t. CO2 ekvivalen- } \\
\text { tu /mln. Eur BVP } \\
\text { T/mln Eur BVP }\end{array}$ & $\begin{array}{l}2010 \\
2010\end{array}$ & $\begin{array}{l}0,78 \\
1,3\end{array}$ & 1,78 & 0,15 & 0,61 \\
\hline Pakuočiu atlieku perdirbimo norma & $\begin{array}{l}\text { Proc. nuo bendro } \\
\text { pakuočiu atlieku kiekio }\end{array}$ & 2010 & 60,4 & 79,8 & 28,5 & 0,62 \\
\hline
\end{tabular}


1B lentelès pabaiga

\begin{tabular}{|c|c|c|c|c|c|c|}
\hline \multirow[t]{2}{*}{ Rodikliai } & \multirow[t]{2}{*}{ Matmenys } & \multirow[t]{2}{*}{ Metai } & \multicolumn{4}{|l|}{ Reikšmès } \\
\hline & & & Lietuvos & Maks. & Min. & Normalizuota \\
\hline Atsinaujinančiųjų išteklių dalis & $\begin{array}{l}\text { Proc. nuo bendrų ener- } \\
\text { gijos sąnaudų }\end{array}$ & 2011 & 20,3 & 64,7 & 0,4 & 0,31 \\
\hline Verslo pradžios sudètinis rodiklis $^{8}$ & Balai & 2012 & 103 & 185 & 1 & 0,45 \\
\hline Mokesčių mokejjimų rodiklis ${ }^{9}$ & Balai & 2012 & 60 & 185 & 1 & 0,68 \\
\hline Prekybos laisvès rodiklis ${ }^{10}$ & Balai & 2012 & 87,1 & 100 & 0 & 0,87 \\
\hline Investavimo laisvès rodiklis $^{11}$ & Balai & 2012 & 80 & 100 & 0 & 0,80 \\
\hline Darbo jègos laisvès indeksas ${ }^{12}$ & Balai & 2013 & 64,1 & 100 & 0 & 0,64 \\
\hline Darbdavių ir darbuotojų santykių pagrindas & Balai & 2013 & 0,55 & 1 & 0 & 0,55 \\
\hline Darbo užmokesčio santykis su darbuotojo našumu & Balai & 2013 & 0,57 & 1 & 0 & 0,57 \\
\hline Gebejjimas išlaikyti ir pritraukti talentingus žmones & Balai & 2013 & 0,4 & 1 & 0 & 0,40 \\
\hline Moterų dalyvavimas darbo rinkoje & Proc. & 2010 & 85 & 87 & 39 & 0,96 \\
\hline Finansinio sektoriaus produktų verslui gausumas & Balai & 2013 & 0,57 & 1 & 0 & 0,57 \\
\hline Galimybės gauti lèšų išleidžiant akcijas & Balai & 2013 & 0,38 & 1 & 0 & 0,38 \\
\hline Juridinių teisių stiprumo indeksas ${ }^{13}$ & Balai & 2012 & 5 & 10 & 0 & 0,50 \\
\hline Finansu ir bankininkystès reguliavimo veiksmingumas & Balai & 2013 & 0,57 & 1 & 0 & 0,57 \\
\hline Paskolos gavimo lengvumas & Balai & 2013 & 0,33 & 1 & 0 & 0,33 \\
\hline Rizikos kapitalo prieinamumas & Balai & 2013 & 0,35 & 1 & 0 & 0,35 \\
\hline Gerai išplètotų klasteriu paplitimas & Balai & 2013 & 0,3 & 1 & 0 & 0,30 \\
\hline Auditų ir apskaitos standartų stiprumas & Balai & 2013 & 0,72 & 1 & 0 & 0,72 \\
\hline Investuotojų apsaugos stiprumo indeksas ${ }^{14}$ & Balai & 2012 & 5,7 & 10 & 0 & 0,57 \\
\hline Imonių valdybu efektyvumas & Balai & 2013 & 0,6 & 1 & 0 & 0,60 \\
\hline Profesionalaus valdymo paplitimas & Balai & 2013 & 0,57 & 1 & 0 & 0,57 \\
\hline Valdymo funkciju perdavimo praktika & Balai & 2013 & 0,53 & 1 & 0 & 0,53 \\
\hline Verslo etika & Balai & 2013 & 0,6 & 1 & 0 & 0,60 \\
\hline Socialinès atsakomybès lygis & Balai & 2013 & 0,48 & 1 & 0 & 0,48 \\
\hline Vertès kūrimo grandinès plotis & Balai & 2013 & 0,53 & 1 & 0 & 0,53 \\
\hline Gamybos proceso modernumas & Balai & 2013 & 0,52 & 1 & 0 & 0,52 \\
\hline Rinkodaros naudojimas & Balai & 2013 & 0,57 & 1 & 0 & 0,57 \\
\hline Orientacija i klientus & Balai & 2013 & 0,55 & 1 & 0 & 0,55 \\
\hline
\end{tabular}




\section{C priedas. Lietuvos konkurencingumo veiksnių reikšmingumų nustatymo pavyzdys}

C1 lentelè. Institucinès aplinkos veiksnị sudarančių dalinių veiksnių reikšmingumų nustatymas

Table C1. Calculation of sub-factors' significances of institutional environment factor

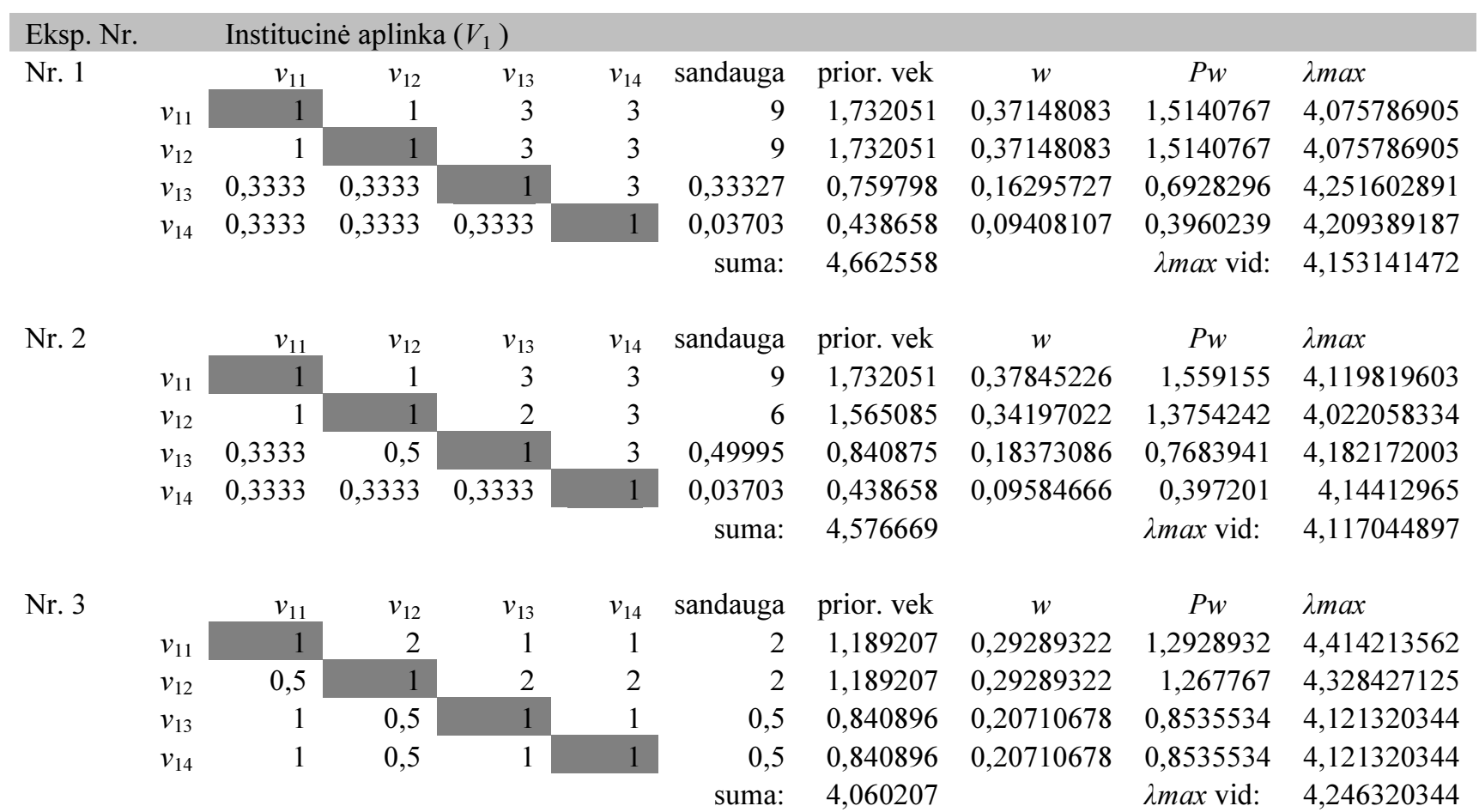


Nr. 4

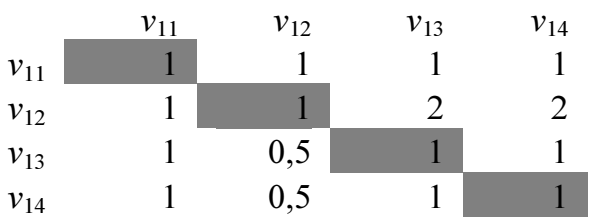
sandauga prior. vek 1,414214 $0,5 \quad 0,840896$ $0,5 \quad 0,840896$ suma: 4,096006 $1 \quad 0,24414024$ 0,34526644

Nr. 5

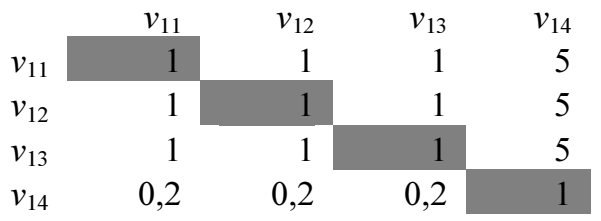

$\begin{array}{rr}\text { sandauga } & \text { prior. vek } \\ 5 & 1,495349 \\ 5 & 1,495349 \\ 5 & 1,495349 \\ 0,008 & 0,29907 \\ \text { suma: } & 4,785116\end{array}$$$
w
$$$$
0,3125
$$$$
0,3125
$$$$
0,3125
$$$$
0,0625
$$

suma: $\quad 4,785116$

Nr. 6

$\begin{array}{rrrrr} & v_{11} & v_{12} & v_{13} & v_{14} \\ v_{11} & 1 & 1 & 3 & 4 \\ v_{12} & 1 & 1 & 3 & 4 \\ v_{13} & 0,3333 & 0,3333 & 1 & 3 \\ v_{14} & 0,25 & 0,25 & 0,3333 & 1\end{array}$

andauga
12
12
0,33327
0,02083

suma:
C1 lentelès pabaiga

\begin{tabular}{cr}
\multicolumn{3}{r}{ C1 lentelès pabaiga } \\
$P w$ & \multicolumn{1}{c}{$\lambda \max$} \\
1 & 4,096006393 \\
1,4105933 & 4,085521011 \\
0,8273668 & 4,03010353 \\
0,8273668 & 4,03010353 \\
$\lambda$ max vid: & 4,060433616
\end{tabular}

\begin{tabular}{cr}
$P w$ & \multicolumn{1}{l}{$\lambda \max$} \\
1,25 & 4 \\
1,25 & \\
1,25 & 4 \\
0,25 & 4 \\
$\lambda \max$ vid: & 4 \\
& 4 \\
$P w$ & $\lambda \max$ \\
1,5469461 & 4,0411598 \\
1,5469461 & 4,0411598 \\
0,6458503 & 4,132949012 \\
0,3216194 & 4,116134318 \\
$\lambda \max$ vid: & 4,082850733
\end{tabular}




\section{D priedas. Lietuvos konkurencingumo pokyčio optimizavimo uždavinio sprendimo rezultatai}

D1 lentelè. Uždavinio rezultatai (Tikimybė 0,6 )

Table D1. Task solution results (probability 0.6)

\begin{tabular}{lcccc}
\multicolumn{5}{c}{ PROC NLP: Nonlinear Maximization } \\
Optimization Results \\
Parameter Estimates \\
Gradient & Gradient & Active \\
Objective & Lagrange & Bound \\
N Parameter & Estimate & Function & Function & Constraint \\
1 z & 3.178669 & -0.253347 & $-1.285308 \mathrm{E}-8$ & \\
$2 \times 1$ & $-1.79124 \mathrm{E}-10$ & 0.282129 & $3.151565 \mathrm{E}-17$ & Lower BC \\
$3 \times 2$ & $-1.58051 \mathrm{E}-10$ & 0.374646 & $-3.36689 \mathrm{E}-17$ & Lower BC \\
$4 \times 3$ & $-1.36977 \mathrm{E}-10$ & 0.444200 & $-2.43497 \mathrm{E}-17$ & Lower BC \\
$5 \times 4$ & $-1.15904 \mathrm{E}-10$ & 0.501365 & $-5.65448 \mathrm{E}-17$ & Lower BC \\
$6 \times 5$ & $-5.26836 \mathrm{E}-11$ & 0.587231 & $3.968568 \mathrm{E}-17$ & Lower BC \\
$7 \times 6$ & $-1.05367 \mathrm{E}-11$ & 0.472940 & $-4.13034 \mathrm{E}-17$ & Lower BC \\
$8 \times 7$ & 6.058119 & 0.694340 & $-6.096678 \mathrm{E}-8$ & \\
$9 \times 8$ & 3.941881 & 0.640929 & $6.0966784 \mathrm{E}-8$ & \\
$10 \times 9$ & $-9.48304 \mathrm{E}-11$ & 0.530207 & $2.940427 \mathrm{E}-17$ & Lower BC \\
$11 \times 10$ & $-1.05367 \mathrm{E}-11$ & 0.437595 & $-2.84344 \mathrm{E}-17$ & Lower BC \\
& Value of Objective Function $=5.9275524475$ &
\end{tabular}

D2 lentelè. Uždavinio rezultatai (Tikimybė 0,7 )

Table D2. Task solution results (probability 0.7)

$$
\begin{aligned}
& \text { PROC NLP: Nonlinear Maximization } \\
& \text { Optimization Results } \\
& \text { Parameter Estimates } \\
& \text { Gradient Gradient Active } \\
& \text { Objective Lagrange Bound }
\end{aligned}
$$

\begin{tabular}{|c|c|c|c|c|}
\hline N Parameter & Estimate & Function & Function & \multirow[t]{2}{*}{ Constraint } \\
\hline $1 z$ & 2.339886 & $-0.524401-$ & -0.000023067 & \\
\hline $2 \times 1$ & $-1.5114 \mathrm{E}-10$ & 0.282129 & $-3.7683 E-17$ & Lower BC \\
\hline $3 \times 2$ & $-1.1953 E-10$ & 0.374646 & $2.382593 \mathrm{E}-17$ & Lower BC \\
\hline $4 \times 3$ & -8.79197E-11 & 0.444200 & 8.920254E-18 & Lower BC \\
\hline $5 \times 4$ & $-5.63095 E-11$ & 0.501365 & $-5.20329 E-17$ & Lower BC \\
\hline $6 \times 5$ & 2.530966 & 0.587231 & 0.000033755 & \\
\hline $7 \times 6$ & $-9.84564 \mathrm{E}-11$ & 0.472940 & 3.998277E-17 & Lower BC \\
\hline $8 \times 7$ & 3.679450 & 0.694340 & -0.000122 & \\
\hline $9 \times 8$ & 3.489068 & 0.640929 & 0.000054723 & \\
\hline $10 \times 9$ & 0.300516 & 0.530207 & 0.000033739 & \\
\hline $11 \times 10$ & $-1.08993 \mathrm{E}-10$ & 0.437595 & $-3.0396 E-17$ & Lower BC \\
\hline
\end{tabular}

Value of Objective Function $=5.2095925874$ 
D3 lentelè. Uždavinio rezultatai (Tikimybė 0,8 )

Table D3. Task solution results (probability 0.8)

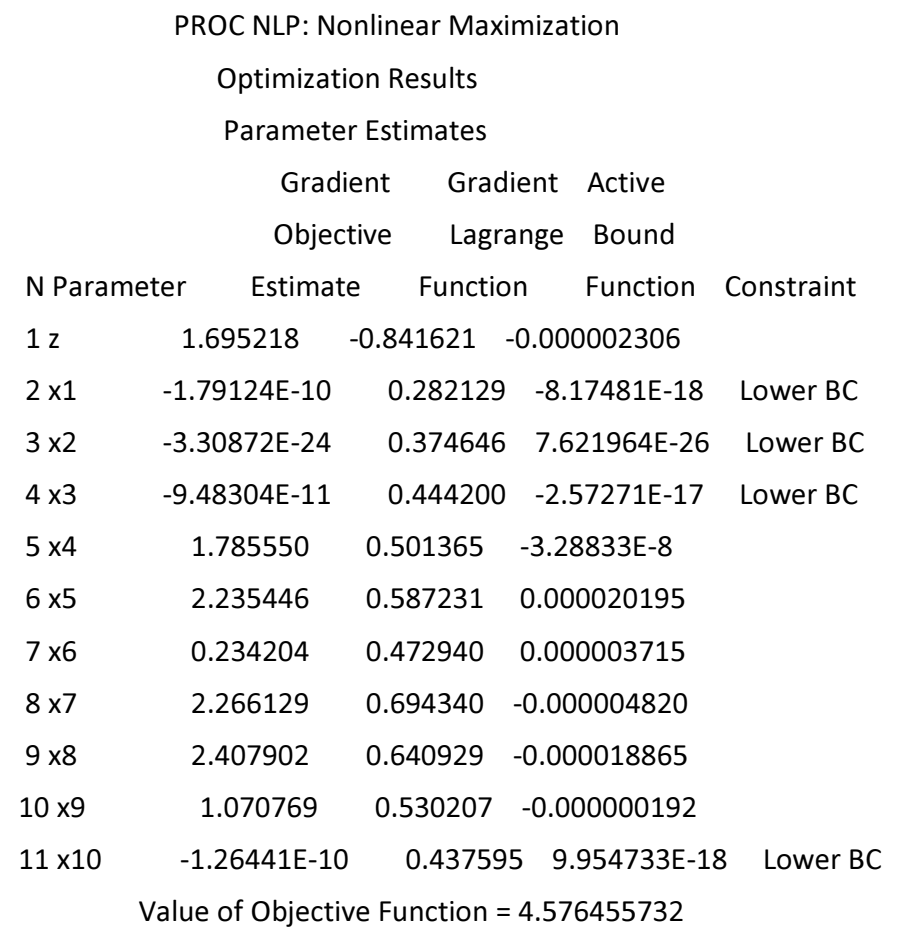

D4 lentelè. Uždavinio rezultatai (Tikimybè 0,9)

Table D4. Task solution results (probability 0.9)

PROC NLP: Nonlinear Maximization

Optimization Results

Parameter Estimates

$$
\begin{array}{cc}
\text { Gradient } & \text { Gradient Active } \\
\text { Objective } & \text { Lagrange Bound }
\end{array}
$$

N Parameter Estimate Function Function Constraint

$1 \mathrm{z} \quad 1.236739 \quad-1.281552-0.000004416$

$\begin{array}{lllll}2 \times 1 & -7.3757 \mathrm{E}-11 & 0.282129 & 1.847678 \mathrm{E}-17 & \text { Lower BC }\end{array}$

$3 \times 2 \quad-5.26836 \mathrm{E}-11 \quad 0.374646 \quad-7.94812 \mathrm{E}-18 \quad$ Lower BC

$\begin{array}{llll}4 \times 3 & 1.420911 & 0.444200 & -0.000020927\end{array}$

$\begin{array}{llll}5 \times 4 & 2.083660 & 0.501365 & 0.000084515\end{array}$

$\begin{array}{lllll}6 \times 5 & 1.591043 & 0.587231 & -0.000038879\end{array}$

$\begin{array}{lllll}7 \times 6 & 0.573420 & 0.472940 & 0.000011038\end{array}$

$\begin{array}{lllll}8 \times 7 & 1.374179 & 0.694340 & -0.000042112\end{array}$

$\begin{array}{lllll}9 \times 8 & 1.548847 & 0.640929 & 0.000037512\end{array}$

$\begin{array}{lllll}10 \times 9 & 0.957544 & 0.530207 & -0.000024684\end{array}$

$\begin{array}{llll}11 \times 10 & 0.450396 & 0.437595 & -0.000006464\end{array}$

Value of Objective Function $=3.9480351368$ 
D5 lentelè. Uždavinio rezultatai (Tikimybė 0,95)

Table D5. Task solution results (probability 0.95 )

PROC NLP: Nonlinear Maximization

Optimization Results

Parameter Estimates

$\begin{array}{crrl} & \text { Gradient } & \text { Gradient } & \text { Active } \\ \text { Objective } & \text { Lagrange } & \text { Bound } \\ \text { N Parameter } & \text { Estimate } & \text { Function } & \text { Function Constraint }\end{array}$

$1 z \quad 1.103373 \quad-1.644854-0.000004783$

$2 \times 1 \quad-1.05367 \mathrm{E}-10 \quad 0.282129 \quad 1.206558 \mathrm{E}-17$ Lower BC

$\begin{array}{llll}3 \times 2 & 0.322942 & 0.374646 & -0.000047044\end{array}$

$\begin{array}{llll}4 \times 3 & 1.834889 & 0.444200 & 0.000028177\end{array}$

$5 \times 4 \quad 2.027736 \quad 0.501365-0.000067335$

$\begin{array}{llll}6 \times 5 & 1.349621 & 0.587231 & -0.000003677\end{array}$

$\begin{array}{llll}7 \times 6 & 0.615092 & 0.472940 & 0.000014746\end{array}$

$\begin{array}{llll}8 \times 7 & 1.090448 & 0.694340 & -0.000016742\end{array}$

$9 \times 8 \quad 1.262512 \quad 0.640929-0.000011876$

$\begin{array}{llll}10 \times 9 & 0.874059 & 0.530207 & 0.000000436\end{array}$

$11 \times 10 \quad 0.622701 \quad 0.437595 \quad 0.000103$

Value of Objective Function $=3.5234805525$
D6 lentelè. Uždavinio rezultatai (Tikimybė 0,99)

Table D6. Task solution results (probability 0.99)

PROC NLP: Nonlinear Maximization

Optimization Results

Parameter Estimates

$\begin{array}{rr}\text { Gradient } & \text { Gradient } \\ \text { Objective Lagrange }\end{array}$

$N$ Parameter Estimate Function Function

$\begin{array}{llll}1 z & 1.000698 & -2.326348 & 0.000007551\end{array}$

$\begin{array}{llll}2 \times 1 & 0.006769 & 0.282129 & -0.000090381\end{array}$

$\begin{array}{lllll}3 \times 2 & 0.864783 & 0.374646 & -0.000013838\end{array}$

$\begin{array}{lllll}4 \times 3 & 2.087148 & 0.444200 & -0.000045540\end{array}$

$\begin{array}{llll}5 \times 4 & 1.918051 & 0.501365 & 0.000084975\end{array}$

$\begin{array}{lllll}6 \times 5 & 1.126978 & 0.587231 & -0.000004031\end{array}$

$\begin{array}{llll}7 \times 6 & 0.626591 & 0.472940 & 0.000024815\end{array}$

$\begin{array}{lllll}8 \times 7 & 0.844334 & 0.694340 & 0.000002902\end{array}$

$\begin{array}{lllll}9 \times 8 & 1.008766 & 0.640929 & -0.000031960\end{array}$

$\begin{array}{llll}10 \times 9 & 0.784075 & 0.530207 & 0.000032686\end{array}$

$\begin{array}{llll}11 \times 10 & 0.732503 & 0.437595 & 0.000040373\end{array}$

Value of Objective Function $=2.813879831$ 
Giedre RAKAUSKIENE

ŠALIES KONKURENCINGUMO SKATINIMO

SPRENDIMŲ PAGRĮSTUMO DIDINIMAS

Daktaro disertacija

Socialiniai mokslai,

ekonomika (04S)

\author{
THE INCREASE OF VALIDITY OF NATIONAL \\ COMPETITIVENESS' PROMOTION DECISIONS \\ Doctoral Dissertation \\ Social Sciences, \\ Economics (04S)
}

201311 12. 11,5 sp. I. Tiražas 20 egz.

Vilniaus Gedimino technikos universiteto

leidykla "Technika“"

Saulètekio al. 11, 10223 Vilnius,

http://leidykla.vgtu.lt

Spausdino UAB "Ciklonas"

J. Jasinskio g. 15, 01111 Vilnius 